https://helda.helsinki.fi

\title{
Katsomusaineiden kehittämishaasteita : opettajankoulutuksen tutkinnonuudistuksen virittämää keskustelua
}

Käyttäytymistieteellinen tiedekunta, Helsingin yliopisto

2007

Kallioniemi , A \& Salmenkivi , E (toim) 2007 , Katsomusaineiden kehittämishaasteita : opettajankoulutuksen tutkinnonuudistuksen virittämää keskustelua . Tutkimuksia / Helsingin yliopiston soveltavan kasvatustieteen laitos , Nro 279 , Käyttäytymistieteellinen tiedekunta, Helsingin yliopisto , Helsinki . https://doi.org/10.31885/2018.00020

http://hdl.handle.net/10138/238991

https://doi.org/10.31885/2018.00020

publishedVersion

Downloaded from Helda, University of Helsinki institutional repository.

This is an electronic reprint of the original article.

This reprint may differ from the original in pagination and typographic detail.

Please cite the original version. 


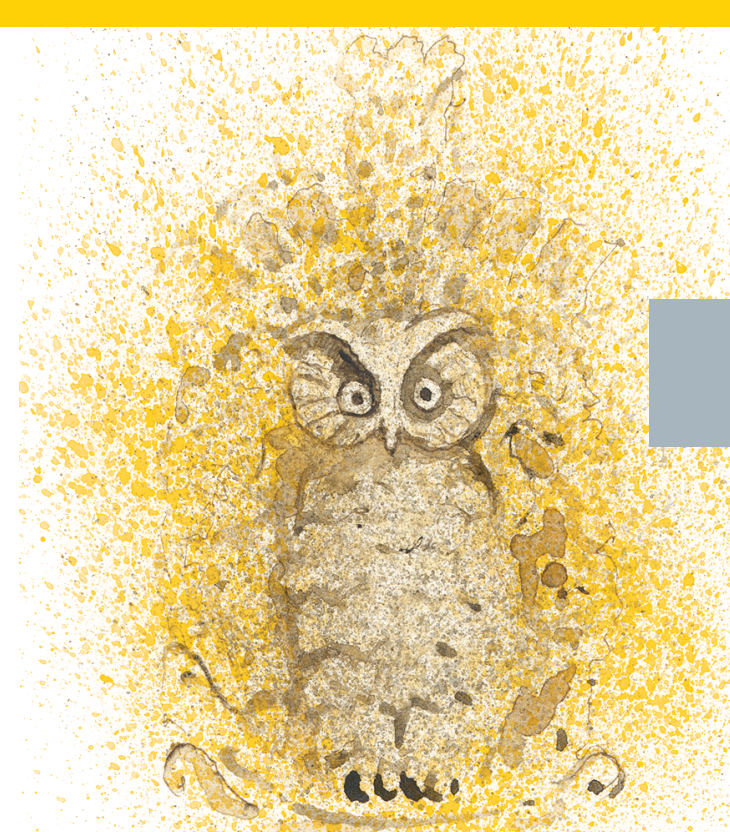


Julkaisusarjan toimituskunta:

Jarkko Hautamäki

Juhani Hytönen (Puheenjohtaja)

Arto Kallioniemi

Leena Krokfors

Jari Lavonen

Kirsti Lonka

Matti Meri

Mikko Ojala

Erkki Pehkonen

Heikki Ruismäki

Sirpa Tani

Seppo Tella

Kari Uusikylä

Mauri Åhlberg

Kari Perenius (Sihteeri)

Soveltavan kasvatustieteen laitos

PL 9 (Siltavuorenpenger 20R)

00014 Helsingin yliopisto

Puhelin + 358919129603

Telefax + 358919129611

http://www.helsinki.fi/behav/kirjasto/palvelut/

julkaisumyynti/soklatut3

Tutkimuksia 279

ISBN 978-952-10-3598-2 (Nid.)

ISBN 978-952-10-3599-9 (Pdf)

ISSN 1795-2158

Saatavissa verkkojulkaisuna:

http://www.helsinki.fi/vokke/english/katsomus.pdf

Kannen taitto: Annukka Salo-Tolvanen

Kannen kuva: Jussi Anttonen

Kustantaja:

Valtakunnallinen opettajankoulutuksen ja kasvatustieteiden tutkintojen kehittämisprojekti (Vokke), Käyttäytymistieteellinen tiedekunta, Helsingin yliopisto

http://www.helsinki.fi/vokke/

http://www.helsinki.fi/vokke/english/publications 


\section{Katsomusaineiden kehittämishaasteita}

\section{Opettajankoulutuksen tutkinnonuudistuksen virittämää keskustelua}



Tutkimuksia 279

Arto Kallioniemi ja Eero Salmenkivi (toim.)

Katsomusaineiden kehittämishaasteita

Opettajankoulutuksen tutkinnonuudistuksen virittämää keskustelua 
ISBN 978-952-10-3598-2 (Nid.)

ISBN 978-952-10-3599-9 (Pdf)

ISSN 1795-2158

Yliopistopaino

2007 


\section{Esipuhe}

Vuosina 2003-2006 toimineen Valtakunnallisen opettajankoulutuksen ja kasvatustieteiden tutkintojen kehittämisprojektin (eli Vokke-projektin) tavoitteena oli tukea yliopistoja kaksiportaisen tutkintorakenteen luomisessa näille aloille. Projekti pyrki tavoitteeseensa järjestämällä koulutus- ja neuvottelutilaisuuksia, edistämällä yhteistyötä yliopistojen välillä sekä arvioimalla uudistuksen vaikutuksia.

Yhdeksi erityistä huomiota opettajankoulutuksessa vaativaksi aineryhmäksi osoittautuivat katsomusaineet, joista projektissa vastasi uskonnon ja elämänkatsomustiedon jaos. Vokke-projekti järjesti yhdessä Helsingin yliopiston soveltavan kasvatustieteen laitoksen kanssa Helsingissä 11.11.2005 Katsomusopetuksen kehitysnäkymät -seminaarin, jossa tarkasteltiin uskonnon ja elämänkatsomustiedon opetuksen kehittämisvisioita. Seminaarin näkökulmina olivat erityisesti uskonnon ja elämänkatsomustiedon opetuksen tämän päivän tilanne, vähemmistöjen katsomusopetus ja oppiaineiden opetus tulevaisuudessa. Seminaarin materiaaleja on julkaistu Vokke-projektin sivulla (http://www. helsinki.fi/vokke/seminaarit2005).

Katsomusopetuksen kehitysnäkymät -seminaarissa pidetyt alustukset on koottu tähän kirjaan. Kirjaan otettiin mukaan myös muita alan kehittämisen kannalta tärkeitä artikkeleita, jotta kirja laajemmin palvelisi ajankohtaisena uskonnon ja elämänkatsomustiedon opetuksen kysymyksiä käsittelevänä julkaisuna.

Kirja jakaantuu kolmeen jaksoon. Ensiksi tarkastellaan vähemmistöuskontojen opetukseen liittyviä kysymyksiä. Dosentti Tuula Sakaranahon artikkeli pienryhmäisten uskontojen opetuksesta ja monikulttuurisuuden haasteista avaa kiintoisalla tavalla pienryhmäuskontojen opetukseen liittyviä kysymyksiä. Se antaa näköalan siitä, miten moninainen uskonnon ja elämänkatsomustiedon opetuksen kenttä kokonaisuudessaan on. TM Kaarina Lyhykäisen artikkeli vie tarkastelun yhden uskonnon - ortodoksisen uskonnon - opetuksen tasolle. Ortodoksisen uskonnon opetuksen historia suomalaisessa yhteiskunnassa on pitkä. Artikkeli avaa ortodoksisen uskonnon opetuksen historiaa ja nykypäivää. Professori Friedrich Schweitzer tuo artikkelissaan kirjaan kansainvälisen lisän. Hän on pitkään tarkastellut eurooppalaisen uskonnon opetuksen tehtäviä erityisesti lapsen oikeuksien näkökulmasta. Ensimmäisen osa- 
alueen päättää professori Arto Kallioniemen artikkeli laadukkaasta katsomusaineiden opetuksesta. Siinä tarkastellaan muun muassa katsomusaineiden opetuksen kansainvälisiä standardeja ja muuttuvaa toimintakulttuuria.

Toiseksi teoksessa tarkastellaan erityisesti uskonnon opetukseen liittyviä näkökulmia. Professori Arto Kallioniemi esittelee artikkelissaan uskonnon opetusta erityisesti eurooppalaisesta näkökulmasta. Hän myös kuvaa Norjassa tapahtunutta uskonnon opetuksen muutosta. Dosentti Antti Räsänen tarkastelee artikkelissaan kansalaisten käsityksiä uskonnon opetuksesta. Räsäsen artikkeli perustuu laajaan kansalliseen uskonnon opetuksen tehtävää ja toteuttamismalleja tarkastelevaan tutkimukseen. Jakson päättää TM Liisa Odiahin tutkimukseen perustuva artikkeli evankelisluterilaisista uskonnon opettajista monikulttuuristuvan yhteiskunnan kentässä.

Kirjan kolmas osa-alue keskittyy elämänkatsomustiedon opetukseen. Sen aluksi professori Jussi Kotkavuori tarkastelee elämänkatsomustiedon ja koko katsomusopetuksen olemukseen ja substanssiin liittyviä kysymyksiä oppilaiden identiteetin kehittämisen näkökulmasta. Jakson toisessa artikkelissa ylitarkastaja Pekka Elo, FL Eero Salmenkivi, FM Tuukka Tomperi ja fil. yo Tuulia Ahola-Luttila tarkastelevat elämänkatsomustiedon historiaa ja haasteita kouluaineena erityisesti uskonnon vapauden kehittymisen näkökulmasta.

Vokke-projektin uskonnon ja elämänkatsomustiedon jaos on erittäin kiitollinen dosentti, johtaja Ritva Jakku-Sihvoselle, joka mahdollisti kirjan julkaisemisen. Dosentti Jakku-Sihvosen dynaaminen ja tavoitteellinen ote kannusti jaoston toimintaa sekä kirjan julkaisemisessa että monella muulla tavalla. Uskonnon ja elämänkatsomustiedon jaos kiittää FM Leena Lehtimäkeä, joka teki hyvää yhteistyötä uskonnon ja elämänkatsomustiedon jaoksen kanssa. KL Satu Uusiautti ja KM Varpu Tissari osallistuivat Katsomusopetuksen kehitysnäkymät -seminaarin järjestelyihin sekä avustivat nyt julkaistavan kirjan toimittamisessa. Jaos on kiitollinen heidän antaumuksellisesta panostuksestaan yhteistyöhön. Kiitämme myös teoksen kirjoittajia hyvin toimineesta yhteistyöstä ja professori Juhani Hytöstä, joka soveltavan kasvatustieteen laitoksen johtajana hyväksyi teoksen laitoksen julkaisusarjaan, sekä KM Kari Pereniusta, joka osaavasti vastasi teoksen taitosta ja saattamisesta teknisesti painokuntoon.

Suomalainen yhteiskunta muuttuu ja kehittyy jatkuvasti. Globalisaatio, monikulttuuristuminen ja tietoverkoissa toimiminen ovat aikamme avainsanoja. Yhteiskunnallinen ja käsitteellinen todellisuus näiden avainsanojen takana on usein vaikea tavoittaa. Uskonto ja elämänkatsomustieto ovat kulttuurilukuaineita, jotka avaavat mahdollisuuksia tuon todellisuuden ymmärtämiseen. Kouluaineina uskonto ja elämänkatsomustieto kiinnittyvät suomalaisen yhteiskunnan arvoperustaan ja tuovat kouluun moninaisten muutosten keskel- 
le vahvan humanismiin perustuvan näkökulman. Kirjan julkaisemisella uskonnon ja elämänkatsomustiedon jaos haluaa tuoda oman panoksensa valtakunnalliseen opettajankoulutuksen kehittämisprojektiin ja kiinnittää alan asiantuntijoiden ja kehittäjien huomiota näiden aineiden kehittämisvisioihin.

Helsingissä maaliskuun 1. päivänä 2007

Arto Kallioniemi

Eero Salmenkivi 



\section{Sisällys}

\section{Pienryhmä- ja vähemmistöuskontojen opetus}

1 Pienryhmäisten uskontojen opetus ja monikulttuurisuuden haasteet...........3 Tuula Sakaranaho

2 Vähemmistön uskonnon opetusta profiloimassa 17 Kaarina Lyhykäinen

3 Children's Right to Religion: A Challenge to Religious Education 25 Friedrich Schweitzer

4 Laadukas katsomusaineiden opetus .41 Arto Kallioniemi

\section{Uskonnon opetus}

5 Näkökulmia eurooppalaiseen uskonnon opetukseen - oppiaineen kehittämisen haasteita Norjassa ja Suomessa 55 Arto Kallioniemi

6 Kansalaisten käsityksiä peruskoulun uskonnon opetuksesta .77 Antti Räsänen

7 Evankelisluterilaisen uskonnon opettajat ja uskonnon opetuksen tulevaisuus monikulttuuristuvassa yhteiskunnassa 


\section{Elämänkatsomustiedon opetus}

8 Elämänkatsomustiedon opetuksen pitkän aikavälin kehitystehtävistä 113

Jussi Kotkavirta

9 Elämänkatsomustiedon kehkeytyminen 125

Eero Salmenkivi, Pekka Elo, Tuukka Tomperi

ja Tuulia Ahola-Luttila 


\section{I}

\section{Pienryhmä- ja}

\section{vähemmistöuskontojen opetus}





\title{
Pienryhmäisten uskontojen opetus ja monikulttuurisuuden haasteet
}

\author{
Tuula Sakaranaho
}

Tiivistelmä

Monikulttuuristumisen myötä myös uskontojen kirjo kouluissa on kasvanut. Lain mukaan oppilailla on oikeus oman uskonnon opetukseen koulussa, jos tietyt reunaehdot oppilaiden lukumääristä täyttyvät. Nämä reunaehdot täyttävistä uskonnoista opetetaan tällä hetkellä kouluissa pääsääntöisesti kolmea kristinuskon muotoa eli luterilaisuutta, ortodoksisuutta ja katolisuutta sekä ei-kristillistä uskonnoista islamia, buddhalaisuutta, baha'ita ja krishna uskontoa. Juutalaisuuden opetus on keskittynyt Helsingin juutalaiseen kouluun. Tässä artikkelissa käsitellään pienryhmäisten uskontojen opetusta koulussa, mukaan lukien ortodoksisen uskonto, käymällä läpi asiaan liittyvä lainsäädäntöä, opetussuunnitelmia ja opetuksen käytännönjärjestelyihin liittyviä kysymyksiä.

Avainsanat: monikulttuurisuus, pienryhmäisten uskontojen opetus, uskonnonvapaus

\section{Uskonnon opetus ja lisääntyvä monikulttuurisuus}

Viime vuosikymmenenä tapahtunut suomalaisen yhteiskunnan nopea monikulttuuristuminen näkyy myös kouluissa. Suomen ja ruotsinkielisten ohella varsinkin pääkaupungin kouluissa on jo noin kolmeakymmentä eri kieltä puhuvia oppilaita. Oppilaat tulevat eri puolilta maailmaa ja tuovat omat kulttuuriperinteensä mukanaan; monikulttuuristumisen myötä myös uskontojen kirjo kouluissa on kasvanut. Yhtenä syynä tähän on uusi, vuonna 2003 voimaan astunut Uskonnonvapauslaki (453/2003), jonka yhteydessä uudistettiin myös Peruskoululaki (454/2003) ja Lukiolaki (455/2003). Lain mukaan oppilailla on oikeus oman uskonnon opetukseen koulussa, jos tietyt reunaehdot oppilaiden lukumääristä täyttyvät. Nämä reunaehdot täyttävistä uskonnoista kouluissa opetetaan pääsääntöisesti kolmea kristinuskon muotoa eli luterilaisuutta, ortodoksisuutta ja katolisuutta sekä ei-kristillistä uskonnoista islamia, buddhalaisuutta, baha'ita ja krishna uskontoa. Juutalaisuuden opetus on keskittynyt Helsingin juutalaiseen kouluun. 
Lain antama oikeus ei kuitenkaan välttämättä takaa eri uskontojen välistä käytännön tasavertaisuutta, minkä vuoksi suomalaisella yhteiskunnalla yleensä ja erityisesti kouluilla on vielä pitkä matka aitoon monikulttuurisuuteen. Monikulttuurisuutta on määritelty lukuisin eri tavoin. Tässä yhteydessä sillä ymmärretään kahdensuuntaista sopeutumisprosessia, joka koskettaa sekä vallitsevaa yhteiskuntaa että uusia tulokkaita. Maahanmuuttajilla on Suomessa oikeus 'kotoutua' samalla säilyttäen oman kulttuurinsa ja kielensä, kun taas Suomen valtio on mukautunut yhteiskunnan kirjavoitumiseen luomalla erilaisia monikultturisuusohjelmia ja muokkaamalla lainsäädäntöä. Edellä mainittu uusi uskonnonvapauslaki on tästä havainnollinen esimerkki. Käytännössä herää kuitenkin kysymys, miten ja kenen ehdoilla molemminpuolinen sopeutumisprosessi itse asiassa tapahtuu. Monikulttuurisuus on aina enemmän kuin vain yhteiskunnan kirjavoituminen tai normatiiviset maahanmuutto-ohjelmat: monikulttuurisuudessa on kyse myös vallasta ja sen käytöstä (ks. Sakaranaho 2006, 62-68).

Kriittinen näkökulma monikulttuurisuuteen korostuu nimenomaan kouluissa. Koulut ovat valtion ylläpitämiä laitoksia, joiden tehtävä on kasvattaa uusia kansalaisia suomalaisen yhteiskunnan tarpeisiin. Koulut pyrkivät välittämään lapsille ja nuorille yhteiskunnan tärkeimpiä arvoja ja vahvistamaan näiden kansallista identiteettiä. Siksi niiden toiminta pääsääntöisesti uusintaa vallitsevia yhteiskunnallisia arvoja tasoittamalla oppilaiden välisiä yhteiskunnallisia ja kulttuurisia eroja. Koulukasvatus on keskeinen väline yhteiskunnan pysyvyyden ja jatkuvuuden ylläpitämisessä nopeasti muuttuvassa maailmassa. (Ks. Parekh 2000, 202-203; Davie 2000, 95; Alitolppa-Niitamo 2002; Alitolppa-Niitamo 2004.) Koulujen arvokasvatus toteutuu kaikissa oppiaineissa mutta selkeimmin se näkyy nimenomaan uskonnon opetuksessa. Siksi on kiintoisaa tarkastella, miten uskonnon opetus yhtäl̈ltä heijastelee pyrkimystä yhteiskunnan jatkuvuuteen ja toisaalta reagoi yhteiskunnalliseen muutoksen. Uskonnon opetus on monella tavoin monikulttuurisuuden myrskynsilmässä; sen tehtävä on säilyttää ja sopeuttaa. (Ks. Khir 2000; Schreiner 2000; Holm 2000; Maréchal 2003; Sakaranaho 2006, 315-319.) Mutta miltä tämä arvojen säilyttäminen ja yhteiskunnan muutokseen sopeuttaminen näyttää pienryhmäisten uskontojen opetuksen näkökulmasta, on kysymys, jota seuraavassa tarkastellaan.

\section{Oikeus oman uskonnon opetukseen}

Uuden uskonnonvapauslain (2003) myötä peruskoulu- ja lukiolaissa termi 'oman tunnustuksen mukainen opetus' korvattiin termillä 'oman uskonnon opetus'. Kiinnostavaa tässä käsitteen vaihdossa oli, että sen ei nähty aiheuttavan erityistä muutosta vallitseviin uskonnon opetuksen periaatteisiin ja käy- 
täntöön (ks. Seppo 2003, 182; Sakaranaho 2006, 335). Suomen kouluissa annettava uskonnon opetus on eronnut kirkon opetuksesta jo 1970-luvulla, ja se on lakannut olemasta tunnustuksellista teologisessa mielessä jo vuosikymmeniä sitten (ks. Saine 2000). Suomalainen uskonnon opetus on tunnustuksellista korkeintaan lainsäädännöllisessä ja pedagogisessa mielessä. (Ks. Kähkönen 1976, 238-242; Pyysiäinen 1982, 66-67, 74-75; Seppo 2003, 179-181; Sakaranaho 2006, 332-335.)

Toisaalta uusi laki muotoilee oikeuden uskonnon opetukseen positiivisen pikemminkin kuin negatiivisen uskonnonvapauden hengessä (Seppo 2003, 179). Niinpä se ei korosta oikeutta jättäytyä pois uskonnon opetuksesta vaan oikeutta osallistua oman uskonnon opetukseen - uskonnosta riippumatta. Periaatteessa laki siten asettaa kaikki uskonnot samalle viivalle ja pyrkii edistämään niiden välistä tasa-arvoa. Kaikki uskonnot eivät kuitenkaan ole samanarvoisia lain edessä.

Laki velvoittaa kuntia järjestämään kouluissa enemmistön mukaista uskonnon opetusta (Peruskoululaki 454/2003, 13 §; Lukiolaki 455/2003, 9 §). Koska yli 80 \% suomalaisista kuuluu luterilaiseen kirkkoon, enemmistön uskonnon opetus on kristinuskon opetusta. Laki ei erikseen määrittele, mistä kristinuskosta on kyse. Se kuitenkin asettaa erilleen ortodoksisen uskonnon opetuksen ja antaa oikeuden myös katoliseen uskonnon opetukseen. Koska enemmistön uskonnon opetus ei ole ortodoksista eikä katolista kristinuskoa, ja koska sitä annetaan nimenomaan luterilaiseen kirkkoon kuuluville oppilaille, sitä voidaan kutsua luterilaiseksi uskonnon opetukseksi laajassa merkityksessä. Jättämällä määrittelemättä enemmistön uskonnon, laki periaatteessa sallii sen, että kyse voisi olla muustakin kuin luterilaisesta uskonnosta. Käytännössä on kuitenkin vaikea kuvitella, että lähivuosina mikään uskontokunta ohittaisi jäsenmäärällään luterilaista kirkkoa. Niinpä uusi laki vahvistaa luterilaisen uskonnon opetuksen asemaa suomalaisessa kouluopetuksessa. (Sakaranaho 2006, 336-337.)

Luterilaisen uskonnon opetuksen aseman vahvistaminen tulee esiin myös siinä, että luterilaiseen kirkkoon kuuluvalla oppilaalla ei ole vain oikeus osallistua enemmistön uskonnon opetukseen, vaan sen opetus on hänelle pakollista. Myös muihin uskontokuntiin kuuluvat tai kuulumattomat oppilaat voivat osallistua luterilaiseen uskonnon opetukseen. Sama valinnanvapaus ei siis toimi toisin päin. Luterilaiseen kirkkoon kuuluvalla oppilaalla ei ole oikeutta osallistua jonkin muun uskonnon tai elämänkatsomustiedon opetukseen, vaikka hän itse tai hänen vanhempansa niin haluaisivat. Ainoa poikkeus tästä ovat yli 18vuotiaana lukion aloittavat opiskelijat, jotka voivat vapaasti valita uskonnon ja elämänkatsomustiedon välillä. Koska laki rajoittaa luterilaisten oppilaiden valinnanvapautta, se näyttäisi asettavan enemmistön uskonnon edustajat eriarvoiseen asemaan vähemmistössä oleviin uskontokuntiin kuuluviin ja uskon- 
tokuntiin kuulumattomiin oppilaisiin verrattuna. Ainoa tapa, jolla luterilainen oppilas voi lisätä valinnanvapauttaan, on erota kirkosta. Asia herätti kriittistä keskustelua uuden uskonnonvapauslain valmisteluvaiheessa, mutta rajoitusta ei kuitenkaan poistettu. (Ks. Scheinin 2001; Seppo 2001; Sakaranaho 2006, 337-339.)

Laki määrää myös, että kuntien velvollisuus on järjestää luterilaista tai ortodoksista uskonnon opetusta oppilaille, jotka eivät osallistu enemmistön mukaiseen uskonnon opetukseen, jos heitä on vähintään kolme. Tämä lainkohta on täysin ymmärrettävä ortodoksisen uskonnon kohdalla. Se kuulostaa kuitenkin oudolta, kun on kyse luterilaisista oppilaista, jotka siis muodostavat ylivoimaisen enemmistön muihin uskontokuntiin verrattuna. Ehkä laki tältä osin ennakoi kasvavaa monikulttuurisuutta, jolloin luterilaisuus ei olisi enää enemmistön uskonto joko koko maassa tai jossain kunnassa. Käytännössä tämä lain kohta koskee nyt kuitenkin vain ortodoksioppilaita, joille kunnan pitää siis järjestää oman uskonnon opetusta, jos kunnan alueella on vähintään kolme ortodoksioppilasta. Lain kohdassa tulee ilmi ortodoksisen kirkon asema Suomen toisena kansankirkkona. Kuntien velvollisuus järjestää muun kuin ortodoksisen uskontokunnan opetusta edellyttää kolmen oppilaan lisäksi myös, että näiden vanhemmat vaativat sitä. Ortodoksioppilaiden kohdalla kuntien velvollisuus järjestää näille uskonnon opetusta syntyy siis automaattisesti, kun tietty lukumäärä täyttyy, mutta muiden vähemmistöuskontojen edustajilta vaaditaan lukumäärän lisäksi myös omaa aktiivisuutta. (Sakaranaho 2006, 339340.) Yhteenvetona voi todeta, että laki kohtelee luterilaisen, ortodoksisen ja muiden uskontokuntien oppilaita eri lailla: luterilaisten oppilaiden kohdalla korostuu pakko, ortodoksioppilaiden kohdalla velvollisuus ja muihin vähemmistöuskontoihin kuuluvien oppilaiden kohdalla vapaaehtoisuus.

Laki sitoo oikeuden uskonnon opetukseen uskontokunnan jäsenyyteen. Jäsenyysvaatimus ei ole ongelma luterilaisille, mutta muiden uskontojen kohdalla se saattaa aiheuttaa sekaannusta. Muiden kuin luterilaisen uskonnon edustajat eivät välttämättä koe tarpeelliseksi rekisteröitymistä uskonnollisen yhdyskunnan jäseneksi. Näin on esimerkiksi monien katolisten kohdalla. Joillekin uskonnoille koko ajatus on täysin vieras. Esimerkiksi muslimit ja vapaakirkolliset piirit kritisoivat uskonnonvapauslakiin sisältyvää hyvin kapeaalaista määritelmä uskonnollisesta kuuluvuudesta. Jäseneksi rekisteröityminen on byrokraattinen tapa, jota monet uskonnot yksinkertaisesti vierastavat. Muslimeista vain noin 10-15\% on jonkin islamilaisen yhdyskunnan jäseniä, ja tämän vuoksi heillä ei periaatteessa ole oikeutta vaatia islamin opetusta koulussa, vaikka perheet tai opiskelijat niin haluaisivat. (Sakaranaho 2006, 132-133, 145-147.) Pohjaamalla uskonnolliset oikeudet jäsenyyteen, uusi uskonnonvapauslaki käyttää mallinaan suomalaista ja yleensä pohjoismaista kirkkoon kuulumista, joka ei perustu valintaan vaan tapaan (vrt. Seppo 2001). Näin 
uusi uskonnonvapauslaki vahvistaa vallitsevan käytännön ja suosii välillisesti uskonnollista organisaatiota yksilön oikeuksien sijaan (vrt. Evans 2001, 132; Sakaranaho 2006, 339). Monikulttuurisuuden näkökulmasta uusi uskonnonvapauslaki on 'vanha' jo syntyessään, sillä se heijastelee instituutiokeskeistä, enemmistökulttuurista ajattelua ja jättää huomiotta vähemmistöuskontojen erilaisuuden ja moninaisuuden. Uusi laki on luotu enemmistön näkökulmasta, eikä se muuta vallitsevan uskonnon eli luterilaisuuden etulyöntiasemaa vähemmistöihin nähden. Lyhyesti uusi laki laajentaa enemmistön nauttimia oikeuksia vähemmistöille mutta tekee sen tiukasti enemmistön ehdoilla. Enemmistön oikeuksien laajentaminen vähemmistöille on kieltämättä yleinen tapa vastata monikulttuurisuuden haasteisiin myös muissa Euroopan maissa. (Ks. Seppo 2003, 30-4 ; Sakaranaho 2006, 116-119; vrt. Mullally 2001, 115; Sakaranaho 2006, 193-194, 422-424.)

Enemmistökulttuurinen ajattelu näkyy myös joidenkin kuntien toiminnassa. Pääkaupunkiseudun kunnat järjestävät islamin opetusta, vaikka suurin osa muslimeista ei olekaan virallisesti islamilaisten yhdyskuntien jäseniä. Uskonnolliseen yhdyskuntaan kuulumattomalla muslimioppilaalla on siten lain mukaan kolme vaihtoehtoa: hän voi valita luterilaisen uskonnon opetuksen, islamin opetuksen tai elämänkatsomustiedon välillä. Käytännössä tilanne on kuitenkin toinen. Jotkut kunnat, kuten Espoo, on ottanut käytännöksi ohjata kaikki muslimioppilaat islamin opetukseen. Espoossa islamin opetus on muslimioppilaille 'pakollinen' samalla tavoin kuin luterilainen uskonnon opetus luterilaiseen kirkkoon kuuluville oppilaille. Toimintatavallaan Espoo asettaa enemmistön ja vähemmistön muodollisesti tasavertaiseen asemaan mutta jättää huomioimatta uskontoperinteiden väliset erot sekä ohittaa vanhempien ja opiskelijoiden oikeudet yksilölliseen päätöksentekoon. (Ks. Sakaranaho 2006, 371-372; vrt. Erikson 2005.)

Koska suomalainen uskonnon opetuksen malli suosii uskontokuntaan perustuvia oikeuksia, se avaa mahdollisuuden, jossa eri uskontojen lisäksi kouluissa opetetaan myös saman uskonnon eri suuntauksia. Tällä hetkellä kouluissa opetetaan luterilaista, ortodoksista ja katolista kristinuskoa. Lain puitteissa samaa voisivat vaatia myös muslimit, jotka jakautuvat pääpiirteissään sunnalaisiin ja šiialaisiin. Suomessa on rekisteröity noin kaksikymmentä islamilaista yhdyskuntaa, jotka lain mukaan voisivat vaatia oman uskontonsa mukaista opetusta. Sama koskee tietenkin myös hindulaisia ja buddhalaisia, joiden määrä kasvaa Suomessa. Vaikka käytännössä kuntien velvollisuus on järjestää vain yhdenlaista eri uskontojen uskonnon opetusta, uusi uskonnonvapauslaki on synnyttänyt tilanteen, jonka käytännön toteutus on hankala (Holma 2000). Eri uskontojen opetus lisää kuntien työtaakkaa ja vaatii varoja, minkä vuoksi vallitseva uskonnon opetuksen malli on erittäin raskas varsinkin pienille kunnille (ks. Liiten 2003). Käytännön ongelmista huolimatta voi ajatella, että 
oikeus oman uskonnon opetukseen on valtion käden ojennus vähemmistössä oleville uskonnollisille yhdyskunnille, jotka kieltämättä arvostavat saamaansa tunnustusta. Uskonnon opetus voi myös auttaa maahanmuuttajataustaisten oppilaiden integroitumista suomalaiseen yhteiskuntaan. (Ks. Lempinen 2002, 120; Sakaranaho ja muut 2004; Sakaranaho 2006, 380.)

\section{Kohti tunnustuksetonta uskonnon opetusta}

Opetushallituksen tehtävänä on laatia opetussuunnitelmat peruskoulun ja lukion käyttöön. Edelliset uskonnon opetussuunnitelmat laadittiin vuonna 1994 ja nykyiset uuden uskonnonvapauslain voimaantulon (2003) jälkeen vuosina 2003-2006. Opetussuunnitelmien välissä on siten lähes kymmenen vuotta, minä aikana Suomi on voimakkaasti monikulttuuristunut. Opetussuunnitelmat määrittelevät uskonnon opetuksen yleiset tavoitteet, jotka koskevat kaikkia uskontoja. Yleisten tavoitteiden mukaan uskonnon opetuksen pitää yhtäältä tarjota tietoa kunkin oppilaan omasta uskonnollisesta perinteestä mutta toisaalta tutustuttaa nämä myös muihin uskontoihin ja maailmankatsomuksiin. (Perusopetuslain muutosten vaikutukset uskonnon ja elämänkatsomustiedon opetukseen sekä koulun toimintaan, OPH 10.10.2003.) Toisin sanoen koulun uskonnon opetuksen tavoitteena on antaa oppilaille erilaisia uskontoja ja maailmankatsomuksia koskeva yleissivistys. Katsomuksellisen yleissivistyksen tavoitteena on kasvattaa lapsia ja nuoria, jotka kykenevät elämään monikulttuurisessa yhteiskunnassa, tekemään itsenäisiä arvovalintoja, ottamaan yhteiskunnallista vastuuta ja osallistumaan kulttuurien väliseen vuorovaikutukseen. Toimiminen monikulttuurisessa yhteiskunnassa edellyttää oppilailta eri uskontojen ja katsomusten 'kulttuurista lukutaitoa' ja kykyä ymmärtää uskonnon merkityksen yksilöille, yhteiskunnille ja kulttuureille. (Seppo 2003, 180; Iivonen 2004.)

Uskonnon opetuksen yleistavoitteissa on uutena asiana oppilaiden perehdyttäminen 'suomalaiseen katsomusperinteeseen'. Tämä on kirjattu tavoitteisiin erillään uskonnoista ja katsomuksista, mutta sen sisältö jää määrittelemättä. Yleiset tavoitteet puhuvat uskonnoista ja katsomuksista monikossa, mutta 'suomalainen katsomusperinne' esitetään yksikössä - ikään kuin se olisi jonkin kaikkien tuntema yhtenäinen kokonaisuus. (Perusopetuksen uskonnon opetuksen perusteet 2004.) Ehkä tässä tavoitteessa on luettavissa viranomaisten huoli siitä, että suomalaisen yhteiskunnan monikulttuuristuessa oppilailta katoaa käsitys siitä, mitä on Suomi, suomalaisuus ja suomalainen perinne. Monikulttuurisuus synnyttää siis tarpeen yksikulttuuriseen korostukseen. Samanlainen oman kulttuuriperinteen korostus on nähtävissä myös muissa Pohjoismaissa ja 
Länsi-Euroopan maissa. (Ks. Otterbeck 1999; MacNeill 2000; Allievi 2003, 371; Sakaranaho 2006, 350-351.)

Yhteisistä tavoitteista huolimatta eri uskontojen opetuksessa on selviä eroja enemmistöuskonnon ja vähemmistöuskontojen välillä. Kuten edellä mainittiin, luterilainen uskonnon opetus erotettiin kirkon opetuksesta jo vuosikymmeniä sitten, jolloin se lakkasi olemasta teologisessa mielessä 'tunnustuksellista' uskonnon opetusta. Nykyään se määritellään luonteeltaan jonkinlaiseksi 'yleiskristillisyyden' opetukseksi, eikä suinkaan luterilaiseksi opetukseksi jossain rajatussa merkityksessä (Pyysiäinen 2000, 13, 15; Seppo 2003, 181.) Kun kouluissa kuitenkin opetetaan samanaikaisesti myös ortodoksista ja katolista kristinuskoa, herättää puhe 'yleiskristillisyydestä' kriittisiä kysymyksiä: Mistä enemmistöuskonnon 'yleiskristillisyydessä' on kyse? Miten 'yleiskristillisyys' voi olla kenenkään 'oma uskonto'? Miksi sitä ei suoraan luonnehdita 'luterilaiseksi' uskonnon opetukseksi ortodoksisen ja katolisen opetuksen rinnalla? Mikä ylipäätään on 'oma uskonto', jota enemmistön uskonnon opetuksessa opetetaan? Näkökulmaa voi myös vaihtaa ja kysyä, millaista uskontoa opetettaisiin ortodoksisessa ja katolisessa uskonnon opetuksessa, jos nekin määriteltäisiin 'yleiskristillisyyden' opetukseksi. Mihin silloin enää tarvittaisiin kolmen eri kristinuskon opetusta?

Puhe 'yleiskristillisestä' luterilaisesta uskonnon opetuksesta herättää mielikuvan yleisestä, kaikkia koskevasta ja 'normaalista' uskonnon opetuksesta, josta vähemmistöuskontojen opetus on jonkinlainen poikkeus. Luterilainen uskonnon opetus on vakiinnuttanut asemansa yhtenä koulun oppiaineena. Sen tavoitteet määritellään koulun pedagogisesta tehtävästä ei kirkon opetuksesta käsin. Uudet opetussuunnitelmat pyrkivät 'normalisoimaan' myös pienryhmäisten uskontojen opetuksen, mikä merkitsee niiden irrottamista kunkin uskonnollisen yhdyskunnan tunnustuksesta. Enemmistön uskonnon opetus toimii siten mallina, johon myös vähemmistöuskontojen tulee sopeutua. Yksi opettaja totesi marraskuussa 2004 järjestetyssä pienryhmäisten uskontojen opetusta käsittelevässä opetushallituksen seminaarissa, että uudet uskonnon opetusta koskevat ohjeet on selvästi laadittu enemmistön näkökulmasta käsin. (Sakaranaho 2006, 344.)

Koska uusissa uskonnon opetussuunnitelmissa on luovuttu tunnustuksellisuuden käsitteestä, voi niitä hyvällä syyllä lukea tunnustuksettoman uskonnon opetuksen linjanvetona. Tunnustukseton uskonnon opetus kulminoituu kahteen asiaan: se määräytyy koulun pedagogista lähtökohdista käsin, ja se on selkeästi erotettu uskonnon harjoittamisesta. Tunnustuksettomassa uskonnon opetuksessa oppilaita ei pyritä sitouttamaan vaan perehdyttämään omaan uskontoon. Siksi uskonnon opetus voi tutustuttaa oppilaita erilaisiin uskonnon harjoituksen muotoihin, kuten rukoukseen ja virrenveisuuseen, kunhan se 
on pedagogisesti tarkoituksenmukaista. (Ks. Seppo 2003, 183-184; Iivonen 2004.)

Tunnustuksettoman uskonnon opetuksen omaksuminen luterilaisen uskonnon opetukseen ei ole vaikeaa, koska se on luonteeltaan 'yleiskristillistä'. Ajatus tunnustuksettomasta uskonnon opetuksesta ei kuitenkaan välttämättä istu esimerkiksi katolisuuden tai ortodoksisuuden opetukseen, jossa uskonto ymmärretään olennaiseksi osaksi jokapäiväistä elämää. Myös ortodoksisen uskonnon opettajankoulutus lähtee ortodoksisesta perinteestä nousevista pedagogisista tavoitteista ja ohjaa opettajia sosiaalistamaan lapset ortodoksiseen uskoon. Ortodoksisen uskonnon opetus on myös pedagogisesti integroitu kirkkovuoteen, jolloin opetus noudattelee ortodoksisen kirkon liturgista elämää. (Ks. Buchberger 1988; Aikonen 1998; Aikonen 2004.) Kaiken kaikkiaan katoliselle ja ortodoksiselle uskonnolle puhe erillisestä 'uskonnon harjoittamisesta' on vieras, ja sen vuoksi ongelmallinen. Tässäkin uskonnon opetuksen tavoitteet 'normalisoivat' enemmistöuskonnon luonteen tunnustuksettomana uskonnon opetuksena ja perustelevat sen kielenkäytöllä, joka heijastelee valtauskonnon ymmärrystä. (Sakaranaho 2006, 343-346.)

Pisimmälle vähemmistöuskonnon 'normalisointi' on viety Espoossa, jossa opetetaan 'yleisislamia'. Tavoitteena Espoon kouluissa on antaa sellaista islamin opetusta, jonka kaikki muslimit voivat hyväksyä riippumatta heidän uskonnollisesta suuntautumisestaan (ks. Uittamo 2001, 8; Sakaranaho 2006, 368). Samaa käytäntöä tosin noudatetaan myös muissa Suomen kunnissa, mutta sitä ei ole määritelty niin selkeästi. Käytännön yleisyydestä huolimatta on todettava, että se asettaa muslimit eriarvoiseen asemaan katolisiin ja ortodokseihin verrattuna. Vaikka laki periaatteessa takaa myös islamin eri suuntauksille oikeuden 'oman uskonnon' opetukseen, käytännössä muslimit niputetaan yhdeksi ryhmäksi ja ohitetaan heidät keskinäiset uskonnolliset eronsa. Niinpä Suomen kouluissa opetetaan kolmea kristinuskoa mutta vain yhtä islamia, buddhalaisuutta ja krishna uskontoa. Ajatus jonkinlaisesta yleisuskonnollisuuden opettamisesta on siten keskeistä enemmistön luterilaisessa uskonnon opetuksessa. Siitä on tehty keskeinen myös (suomalaisille) "vieraissa" uskonnoissa, kuten islamissa, mutta se kilpistyy katoliseen ja ortodoksiseen uskonnon opetukseen. Näyttää siis siltä, että valtion ja kunnan viranomaisten näkökulmasta suurin 'normalisoimisen' paine kohdistetaan ei-kristillisiin uskontoihin ja varsinkin islamiin.

\section{Ontuva käytännön toteutus}

Lisääntyvä monikulttuurisuus on lisännyt nopeasti myös eri uskontojen opetusta erityisesti pääkaupunkiseudulla viimeisen kymmenen vuoden aikana, 
kuten edellä todettiin. Selkein kasvu on tapahtunut nimenomaan islamin kohdalla. Pääkaupunkiseudulla islamin opetukseen osallistuvien oppilaiden lukumäärä on kasvanut 2000-luvulla muutamasta sadasta yli tuhanteen ja samalla ohittanut ortodoksiseen uskonnon opetukseen osallistuvien oppilaiden määrän. Muualla Suomessa näiden kahden uskonnon oppilasmäärät ovat suurin piirtein tasoissa. (Talli 2003; Sakaranaho 2006, 352-356.) Nopeasta muutoksesta huolimatta luterilaiseen uskonnon opetukseen osallistuvat oppilaat muodostavat kuitenkin selvän enemmistön, kuten taulukko 1 osoittaa.

Taulukko 1. Uskonnon ja elämänkatsomustiedon (ET) oppilaiden lukumäärät peruskoulussa Helsingissä, Vantaalla ja Espoossa (2004)

\begin{tabular}{l|c|c|c|c}
\hline & & Oppilaiden lukumäärä & \\
& Helsinki & Vantaa & Espoo & Yhteensä \\
\hline USKONTO / ET & & & & \\
\hline Luterilaisuus & 30,145 & 19,225 & 19,831 & 69,201 \\
\hline ET & 3,091 & 1,170 & 1,082 & 5,343 \\
\hline Islam & 1,252 & 704 & 600 & 2,556 \\
\hdashline Ortodoksisuus & 977 & 361 & 355 & 1,693 \\
\hline Katolisuus & 193 & 120 & 121 & 434 \\
\hline Buddhalaisuus & 27 & 5 & 0 & 32 \\
\hline Krishna & 7 & 0 & 0 & 7 \\
\hline
\end{tabular}

Lähde: Helsingin, Vantaan ja Espoon opetusvirastot (Sakaranaho 2006, 354)

Lisääntyneet eri uskontojen oppilasmäärät lisäävät luonnollisesti myös opetettavien uskontojen opettajien tarvetta. Suomessa järjestetään kuitenkin vain luterilaisen ja ortodoksisen uskonnon opettajakoulutusta, minkä vuoksi uusi laki on jättänyt opetusta järjestävät kunnat kummallisen tilanteen eteen: niiden tulee taata eri uskontojen opetus kouluissa, mutta niiltä puuttuvat muodollisesti pätevät opettajat. Kunnat ovat ratkaisseet ongelman palkkaamalla opetustyöhän sopivia henkilöitä ja kouluttamalla näitä omissa seminaareissaan. Ne ovat myös eri tavoin järjestäneet opettajien ohjausta. (Sakaranaho 2006, 375-378.)

Koska muilla kuin luterilaisen ja ortodoksisen uskonnon opettajilla ei ole muodollista pätevyyttä, he joutuvat opettamaan erittäin pienellä palkalla. (Ks. Kaikkonen 2005.) Oman uskonnon opettajana toimiminen saattaa kuitenkin houkutella tilanteissa, joissa työllistyminen on jostain syystä muuten vaikeaa. Esimerkiksi maahanmuuttajille oman uskonnon tai kielen opettajana toimiminen avaa oven suomalaiseen työelämään. Samoin esimerkiksi huivia käyttävät musliminaiset, jotka helposti kohtaavat työantajien ennakkoluuloja, voivat opettaa islamia huivi päässä. Pukeutuminen ei ole ongelma oman uskonnon opetuksessa. (Vrt. Ikkuna islamiin 2002.) Oman uskonnon ja kielen opetuksen 
voi nähdä esimerkkinä etnospesifeistä ammateista, jotka alkoivat yleistyä Suomessa 1990-luvulla (ks. Forsander 2002, 43).

Palkkauksen ohella kaikki vähemmistöuskontojen opettajat kohtaavat hyvin samansuuntaisia ongelmia (ks. Uittamo 2001, 14-5). Koska uskonnon opetuksen tuntimäärä on yhdestä kahteen tuntia viikossa, joutuvat opettajat kiertämään useiden koulujen väliä saadakseen tarvittavat opetustunnit kasaan. Jotkut opettajat saattavat viikon aikana kiertää jopa kymmenessä koulussa. Kiertävinä opettajina heillä ei ole mitään 'kotikoulua', jossa heillä olisi esimerkiksi oma kaappi, vaan he joutuvat kuljettamaan opetusta varten tarvitsemansa aineistot ja välineet mukanaan. Heillä ei ole myöskään mahdollisuutta integroitua mihinkään kouluun. Usein he kuuluvat viimeisinä muuttuneista opetusjärjestelyistä. Kiertäminen on myös raskasta ja kuluttavaa. Lisäksi se on myös kallista. (Karvonen 1998, 18-20; Ghannou 2002, 19; Lempinen 2002, 95-101; Sakaranaho 2006, 377.)

Kiertämisen ohella vähemmistöuskontojen opettajien työn tekee raskaaksi myös hyvin heterogeeniset koululuokat. Koska oppilaita ei ole tarpeeksi eri luokka-asteilla, opettajat joutuvat opettamaan yhdysluokkia ja eriyttämään opetustaan hyvin eri-ikäisten ja -taitoisten oppilaiden välillä. Siksi heidän on myös vaikea noudattaa eri luokka-asteille tarkoitettuja opetussuunnitelmia. Oppilaat saattavat myös tulla eri puolilta maailmaa ja puhua eri kieltä äidinkielenään. Varsinkin islamin opetuksessa on sekä opettajan että oppilaiden äidinkieli on jokin muu kieli kuin suomi. Uskonnon kaltaisessa oppiaineessa kielen merkitys on kuitenkin suuri. Oppilaiden eri-ikäisyyden ja -kielisyyden lisäksi oppilaiden tiedot omasta uskonnosta saattavat olla myös hyvin erilaiset. Esimerkiksi somalialainen ensimmäisen luokan oppilas saattaa tietää islamista enemmän kuin kosovolainen viidesluokkalainen. Yhtä lukuun ottamatta (Lehtinen, Jama Abdellahi \& Telaranta 2003) islamin opetukseen ei ole myöskään oppikirjoja - opettajien oppaista puhumattakaan - minkä vuoksi opettajat joutuvat valmistamaan opetusmateriaalinsa itse. Tilanne on parempi ortodoksisessa ja katolisessa uskonnossa, joissa oppimateriaalin tuottaminen on huomattavasti pitemmällä. Juutalainen koulu taas hyödyntää kansainvälisesti tuotettuja nettisivuja. (Ks. Karvonen 1998, 16; Lempinen 2002, 12; Sakaranaho 2006, 378-379.)

Etnisen, kielellisen ja uskonnollisen erilaisuuden ohella vähemmistöuskontojen opettajat joutuvat myös toimimaan erityisopettajina, mihin heillä ei myöskään ole koulutusta. Varsinkin pakolaisina Suomeen tulleet lapset ja nuoret ovat ehkä joutuneet käymään läpi hyvin traumaattisia kokemuksia, jotka saattavat aiheuttaa psykologisia ongelmia ja oppimisvaikeuksia. (Ks. Duh \& Jama 2002; Sakaranaho 2006, 379.) Maahanmuuton kokeneilla vanhemmilla on kuitenkin usein heikot mahdollisuudet tukea lastensa koulunkäyntiä, koska he eivät tunne suomalaista koulujärjestelmää. Lapset ja nuoret käyvät läpi 
sekä omaa että perheen kotoutumisprosessia, mikä joissakin tapauksissa voi olla hyvinkin raskas. Maahanmuuttoon liittyvät ongelmat näkyvät helposti koulussa oppilaiden väsymyksenä ja keskittymisvaikeuksina, mikä taas heijastuu luokan yleisessä levottomuudessa. Opettajalta vaatii äärimmäistä taitoa opettaa onnistuneesti kirjavaa oppilasjoukkoa ja hallita vaikeita luokkatilanteita. Opettajan on oltava kuin taikuri, kuten yksi islamin opettaja totesi (ks. Lempinen 2002).

Uusi haaste pienryhmäisten uskontojen opetukselle aiheutuu myös lain muutoksesta, jonka seurauksena uskonnon opettajilta ei enää vaadita opetettavan uskonnon uskonnollisen yhdyskunnan jäsenyyttä. Oppilailla on oikeus oman uskonnon opetukseen, mutta opettaja voi opettaa myös muuta kuin omaa uskontoaan. Näin periaatteessa kuka tahansa, jolla on opetettavan uskonnon aineenhallinta ja pedagogiset opinnot, voi siksi opettaa mitä tahansa uskontoa riippumatta hänen vakaumuksestaan tai uskonnollisesta taustastaan. Herää kysymys, voiko esimerkiksi kristitty opettaja opettaa islamia ja päinvastoin. Kysymykseen voi vastata eri tavoin riippuen siitä, miten painottaa henkilökohtaista vakaumusta tai opettajakoulutusta. Yhtäältä voi ajatella, että kunnollinen opettajankoulutus on tärkeämpi kuin henkilökohtainen vakaumus; koulutus ja opetuskokemus takaavat sen, että opettaja pystyy opettamaan myös muuta kuin omaa uskontoaan. (Holm 2000, 15; Maybury 2000; Felderhof 2000.) Toisaalta varsinkin pienryhmäisten uskontojen opettajat korostavat, että 'omaa uskontoa' voi opettaa vain sellainen henkilö, joka tuntee perinteen sisältä päin: opettajan tulee elää oman uskonnon mukaista elämää ja toimia opettamansa uskonnon elävänä esimerkkinä. Jälkimmäisen näkemyksen mukaan uskonto poikkeaa muista oppiaineista, koska se koskettaa ihmisen koko elämää. Siksi se asettaa myös erilaiset vaatimukset opettajalle. (Ks. Lempinen 2002, 50-65; Sakaranaho 2006, 379-380.) Suomen laki näyttää kuitenkin noudattavan edellistä näkemystä, mikä on tietenkin linjassa tunnustuksettoman uskonnon opetuksen kanssa. Laki kyllä antaa oikeuden 'oman uskonnon opetukseen' mutta ei oikeutta käyttää uskonnon opetusta oppilaiden sosiaalistamiseen omaan uskontoperinteeseen. Pienryhmäisten uskontojen näkökulmasta laki siten yhtä aikaa silittää ja lyö korville.

\section{Uskonnon opetus kotoutumisen tukena}

Kaikesta huolimatta pienryhmäisten uskontojen opettajat kannattavat nykyistä uskonnon opetuksen mallia Suomessa. He näkevät oikeuden omaan uskontoon merkkinä siitä, että valtayhteiskunta kunnioittaa vähemmistöjä. Uskonnon opetus voi toimia myös yhtenä suomalaiseen yhteiskuntaan kotouttamisen väylänä. Varsinkin maahanmuuttajataustaisille oppilaille suomalainen koulu- 
järjestelmä on aluksi täysin vieras. Esimerkiksi oppikirjat heijastavat suomalaista kokemusmaailmaa, johon maahanmuuttajataustaisilla oppilailla ei välttämättä ole omakohtaista kosketusta. Vierauden keskellä oman uskonnon tai kielen opetus voi olla kuin keidas, jossa käsitellään oppilaalle tuttuja asioita. (Ks. Alitolppa-Niitamo 2002, 283.) Oppilaille, jotka muuten elävät koko ajan 'vähemmistönä', on myös hyvä kokea kerrankin muodostavansa 'enemmistön' luokassa (Ikkuna islamiin 2002, 8). Siksi uskonnon opetus voi vaikeuksista huolimatta osoittautua tärkeäksi oppilaiden itsetunnon, identiteetin mutta myös suomalaiseen yhteiskuntaan kotoutumisen kannalta (ks. Sakaranaho ja muut. 2004).

\section{Lähteet}

Aikonen, R. (1997). Ortodoksinen uskonnon opetus koulussa. Selvitys ortodoksista uskontoa opettavista opettajista ja opetustyöstä lukuvuonna 1993-94. Helsinki: Opetushallitus.

Aikonen, R. (1998). Ortodoksinen uskonnon opetus Suomessa. Teoksessa Pyysiäinen, M \& Seppälä, J. (toim.), Uskonnonopetuksen käsikirja, 405-439. Helsinki: WSOY.

Aikonen, R. (2004). Oppia uskontoa vai oppia uskonnosta? Uskonnonvapauslaki ja ortodoksinen uskonnon opetus. Seminaariesitelmä Helsingin yliopiston soveltavan kasvatustieteen laitoksella.

Alitolppa-Niitamo, A. (2002). The Generation In-between: Somali Youth and Schooling in Metropolitan Helsinki. Intercultural education, 13 (3), 275-290.

Alitolppa-Niitamo, A. (2004). Somali Youth in the Context of Schooling in Metropolitan Helsinki: A Framework for Assessing Variability in Educational Performance. Journal of Ethnic and Migration Studies 30 (1), 81-106.

Allievi, S. (2003). The Relations between Religions. In Maréchal, B. et. al (eds.), Muslims in the Enlarged Europe. Religion and Society, 369-414. Leiden, Boston: Brill.

Buchberger, I. (1998). Ortodoksisuus Suomessa. Teoksessa Pyysiäinen, M. \& Seppälä, J. (toim.), Uskonnonopetuksen käsikirja, 396-404. Helsinki: WSOY.

Davie, G. (2000). Religion in Modern Europe. A Memory Mutates. Oxford: Oxford University Press.

Duh A. \& Jama, E. (2002). Islam Somaliassa. Ikkuna islamiin 2 - Islam-aineistoa Helsingin koulujen käyttöön, 26-34. Helsingin kaupungin opetusvirasto.

Erikson, H. (2005). Opetushallitus uusii ohjeensa uskonnon opetuksesta. Helsingin Sanomat 28.8 .

Felderhof, M. C. (2000). Religious Education, Indoctrination and Freedom. In Holm, N. G. (ed.), Islam and Christianity in School Religious Education. Religionsvetenskapliga skrifter nr 52, 41-67. Åbo: Åbo Akademi. 
Forsander, A. (2002). Luottamuksen ehdot. Maahanmuuttajat 1990-luvun suomalaisilla työmarkkinoilla. Väestöntutkimuslaitoksen julkaisusarja D 39/2002. Helsinki: Väestöliitto, Väestöntutkimuslaitos.

Ghannou, D. (2002). Opettajan arki. Ikkuna islamiin 2 - Islam-aineistoa Helsingin koulujen käyttöön, 18-20. Helsingin kaupungin opetusvirasto.

Holm, N. G. (2000). Introduction. In Holm, N. G. (ed.), Islam and Christianity in School Religious Education. Religionsvetenskapliga skrifter nr 52, 11-18. Åbo: Åbo Akademi.

Holma, M. (2000). Finland. In Schreiner, P. (ed.), Religious Education in Europe. A Collection of Basic Information about RE in European Countries, 37-41. Münster: ICCS/Comenius-Institute.

Iivonen, P. (2004). Pienryhmäiset uskonnot ja niiden opettaminen Seminaariesitelmä opetushallituksessa.

Ikkuna islamiin (2002). Ikkuna islamiin 2 - Islam-aineistoa Helsingin koulujen käyttöön. Helsingin kaupungin opetusvirasto.

Kaikkonen, R. (2005). Islam ohitti pääkaupunkiseudulla jo ortodoksiuskonnon opetuksen. Helsingin Sanomat, 20.10.

Karvonen, H. (1998). Salaam Aleikum. Islamin opettajien käsityksiä omasta työstään ja uskonnon opetuksesta Helsingin kouluissa. Teemaseminaariesitelmä. Helsingin yliopisto: Opettajankoulutuslaitos

Khir, B. (2000). Religious Education for Muslims in Birmingham. The Case for Faithbased Provision in State Schools. In Holm, N. G. (ed.), Islam and Christianity in School Religious Education. Religionsvetenskapliga skrifter nr 52, 85-108. Åbo: Åbo Akademi.

Kähkönen, E. (1976). Uskonnon opetuksen asema Suomen koulunuudistuksessa 19441970. Helsinki: Suomalainen Teologinen Kirjallisuusseura.

Lehtinen, I., Jama Abdellahi, E. \& Telaranta, M. (2003). Islam yhteinen uskomme. Helsinki: Opetushallitus.

Lempinen, H. (2002). 'Pitäisi olla taikuri'. Islamin opettajien käsitykset islamin uskonnon opetuksesta peruskoulussa. Uskonnonpedagogiikan laudaturtyö. Helsinki: Helsingin yliopisto.

Liiten, M. (2003). Kuntaliitto esittää kouluun uskontotietoa. Helsingin Sanomat 16.1.

Lukiolait 455/2003.

Maréchal, B. (2003). Modalities of Islamic Instruction. In Maréchal, B., Allievi, S., Dassetto, F. \& Nielsen, J. (eds.), Muslims in the Enlarged Europe. Religion and Society, 19-77. Leiden, Boston: Brill.

Maybury. J. (2000). Religious Education in England and Wales: Contemporary Approaches. In Holm, N. G. (ed.), Islam and Christianity in School Religious Education. Religionsvetenskapliga skrifter nr 52. Åbo: Åbo Akademi.

Otterbeck, J. (1999). Skolan, islam ock muslimer. I Svanberg, I. \& Westerlund, D. (red.), Blågul Islam? Muslimer i Sverige, 157-174. Nora: Bokförlaget Nya Doxa.

MacNeill, D. (2000). Religious Education and National Identity. Social Compass 47 (3), 343-351.

Parekh, B. (2000). Rethinking Multiculturalism. Cultural Diveristy and Political Theory. London: McMillan.

Peruskoululait 454/2003. 
Perusopetuksen uskontojen opetuksen perusteet 2004. Helsinki: Opetushallitus.

Perusopetuslain muutosten vaikutukset uskonnon ja elämänkatsomustiedon opetukseen sekä koulun toimintaan 2003. Helsinki: Opetushallitus.

Pyysiäinen, M. (1982). Tunnustuksellinen, tunnustukseton ja objektiivinen uskonnon opetus. Opetussuunnitelma-analyysi Suomen ja Ruotsin peruskoulun uskonnon opetuksen tavoitteista ja sisällöstä. Helsinki: Kirjapaja.

Pyysiäinen, M. (1998). Koulun uskonnon opetuksen luonne. Teoksessa Pyysiäinen, M. \& Seppälä, J. (toim.), Uskonnonopetuksen käsikirja, 41-68. Helsinki: WSOY.

Pyysiäinen, M. (2000). Yksi oppiaine, seitsemän opetussuunnitelmaa. Peruskoulun ja lukion opetushallituksen 1990-luvulla vahvistamien opetussuunnitelmien tunnustuksellinen luonne. Tutkimuksia 223. Helsinki: Helsingin yliopiston opettajankoulutuslaitos.

Sakaranaho, T. (2006). Religious Freedom, Multiculturalism, Islam-Cross-reading Finland and Ireland. Leiden: Brill.

Sakaranaho, T., Alitolppa-Niitamo, A., Martikainen, T. \& Tiilikainen, M. (2004). Religion in Migration. Studies on Muslims in Finland. In Puuronen, V., Häkkinen, A, Pylkkänen, A, Sandlund, T. \& Toivanen, R. (eds.), New Challenges for the Welfare Society, 124-139. Joensuu: Publication of the Karelian Institute.

Scheinin, M. (2001). Koulujen uskonnon opetus ihmisoikeuksien näkökulmasta. Teologinen Aikakauskirja 6, 515-517.

Schreiner, P. (2000). Introduction. In Schreiner, P. (ed.), Religious education in Europe. A Collection of Basic Information about RE in European Countries, 7-11. Münster: ICCS / Comenius-Institute.

Saine, H. (2000). Uskonnon opetus Suomen oppivelvollisuuskoulussa 1900-luvulla. Turun yliopiston julkaisuja. Annales Universitatis Turkuensis. Turku: Turun yliopisto.

Seppo, J. (2001). Uskonnon opetus ja uskonnonvapaus. Teologinen Aikakauskirja 6, $518-21$.

Seppo, J. (2003). Uskonnonvapaus 2000-luvun Suomessa. Helsinki: Edita.

Talli, R. (2003). HS-selvitys: Islam tuli kouluihin Helsingin Sanomat, 22. 9.

Uittamo, M. (2001). Uskontojen ja elämänkatsomusaineiden opetuksesta Espoossa. Espoo: Espoon kaupunki.

Uskonnonvapauslaki 453/2003. 


\title{
Vähemmistön uskonnon opetusta profiloimassa
}

\author{
Kaarina Lyhykäinen
}

\section{Tiivistelmä}

Suomalainen ortodoksisen uskonnon opetus on historiansa aikana joutunut kohtaamaan monia haasteita. Aluemenetykset Neuvostoliitolle ja ortodoksiväestön uudelleenasuttaminen hajalleen ympäri Suomea lienee ollut haasteista vaativimpia. Vuoden 1983 peruskoululaki toi ortodoksisen uskonnon tasa-arvoiseen asemaan enemmistön uskonnon opetuksen kanssa kun opetusryhmän minimikoko pieneni kolmeen. Perusopetuksen opetussuunnitelman perusteiden mukaan ortodoksisen uskonnon opetuksen keskeinen tehtävä on ortodoksisen identiteetin vahvistaminen ja ylläpitäminen. Ortodoksisen uskonnon omaleimaisuus näkyy opetuksen kokonaisvaltaisuudessa ja liturgisen aineksen keskeisyydessä sekä käytännönjärjestelyiden osalta yhdysryhmä- ja vuorokurssiopetuksena. Opetusryhmät ovat lisäksi erittäin heterogeenisiä. Muihin pienryhmäisiin uskontoihin verrattuna ortodoksinen uskonto eroaa siinä, että Suomen ortodoksisella kirkolla on virallinen asema Suomen toisena kansankirkkona ja siinä, että ortodoksiseen uskontoon on saatavilla omaa opettajankoulutusta.

Avainsanat: ortodoksinen uskonto, uskonnon opetus, omaleimaisuus, haasteet

\section{Vähemmistöuskontojen opetuksen tienraivaaja}

Ortodoksisen uskonnon opetus alkoi Suomessa jo autonomian aikana. 1840luvulla syntyi Karjalaan seurakuntakouluja kansanopetusta varten. Opetuskielenä oli yleensä venäjä, mutta suomea ja karjalankieltäkin käytettiin. Kansakoululaitoksen perustaminen 1866 toi myös ortodoksisen uskonnon opetuksen osaksi suomalaista koulujärjestelmää. (Saine 2000, 36.) 1900-luvun alussa Karjalaan perustetut venäläistämiskoulut edesauttoivat suomenkielisen ortodoksisen uskonnon opetuksen kehitystä, sillä venäläistämiskoulujen rinnalle perustettiin yleensä myös suomenkielinen koulu (Saine 2000, 84-85).

Suomen itsenäistyttyä ja Suomen ortodoksisen arkkihiippakunnan siirryttyä Konstantinopolin ekumeenisen patriarkaatin alaisuuteen laadittiin ortodoksisen uskonnon opetukselle oma opetusohjelma (Tomos 1923). Koulukohtainen ryhmäkoko määriteltiin 20 oppilaaksi. Huoltajien tuli myös erikseen anoa 
opetuksen järjestämistä. Ortodoksiopettajat ilmaisivatkin huolestuneisuutensa liian suuresta ryhmäkoosta, jonka vuoksi suuri osa oppilaista jäi opetuksen ulkopuolelle. Myös Suomen kreikkalaiskatolinen kirkollishallitus esitti Kouluhallitukselle, että ryhmäkoon minimimäärästä voitaisiin tinkiä. Kouluhallitus ei kuitenkaan ollut halukas ryhmäkoon muutokseen. (Saine 2000, 85.)

Talvisodan päätyttyä 12.3.1940 Moskovan rauhaan Suomi joutui luovuttamaan Neuvostoliitolle alueita, joilla asui 2/3 Suomen ortodoksiväestöstä. Noin 55000 ortodoksia joutui jättämään kotiseutunsa. Myös kirkkokunnan aineelliset menetykset olivat suuret. On laskettu, että $90 \%$ siitä, mitä kirkkokunta, seurakunnat ja luostarit omistivat, jäi luovutetulle alueelle. (Koukkunen 1982, 59.) Ortodoksien uusissa sijoituspaikoissa uskonnon opetuksen järjestäminen oli erityisen haasteellinen tehtävä. Kirjavarastojen jäätyä luovutetulle alueelle oli oppikirjoista huutava pula. Myöskään opettajia ei ollut aina saatavilla, sillä oppilaita ja opettajia ei oltu välttämättä sijoitettu samoille alueille. Valtio palkkasikin kolme ortodoksisen uskonnon opettajaa kiertämään eri paikkakunnilla ja käymään oppilaiden kanssa lyhyessä ajassa läpi koko vuoden kurssin. Lukuvuoden 1940-41 tilastosta voidaan kuitenkin todeta, ettei panostus ollut riittävä. Ortodoksisia oppilaita oli yhteensä noin 7200 ja heidät oli sijoitettu 800 eri kouluun. Kouluja, joissa täyttyi 20 oppilaan ryhmäkoko oli vain 78. Näissä kouluissa oli oppilaita yhteensä noin 2800, eikä heille kaikille pystytty järjestämään uskonnon opetusta opettajapulan vuoksi. (Koukkunen 1982, 63-64.)

Jatkosodan päätyttyä ja toisen siirtolaiskauden alettua kesällä 1944 oltiin ortodoksisessa kirkkokunnassa jo paljon kokeneempia syntyneen tilanteen suhteen. Ortodoksisten Nuorten Liitto ry. (ONL) kehotti opettajia ja pappeja perustamaan siirtolaisten sijoituspaikkakunnille nuorisokerhoja jo syksyllä 1944 . Ortodoksiset abiturientit saivat ensimmäistä kertaa omat uskonnon ylioppilaskysymykset keväällä 1945 ja ortodoksisia kristinoppikouluja ruvettiin taas kehittämään. (Koukkunen 1982, 100-102.) Suomen Ortodoksisten Opettajain Liitto ry. (SOOL) perustettiin elokuussa 1951 ajamaan jäsentensä asioita ja tehostamaan uskonnon opetusta. Liiton perustamiskokouksesta lähetettiinkin kirkollishallitukselle esitys uskonnon opetussuunnitelmien ja oppikirjojen uudistamiseksi. Monista tukitoimista huolimatta ortodoksisen uskonnon opetuksen järjestelyissä esiintyi suuria vaikeuksia. Suurimpia syitä vaikeuksiin olivat ortodoksisen väestön hajanainen sijoittuminen ja pätevien uskonnon opettajien puute. Opetuksen puutteen katsottiin taas johtavan kirkosta eroamisiin ja sekaavioliitossa syntyneiden lasten kastamiseen luterilaisiksi. Tilanne koettiin niin vaikeaksi, että kirkkokuntaan perustettiin pysyvä toimikunta huolehtimaan uskonnon opetusasioista. (Koukkunen 1982, 116-121.)

Vuoden 1957 kansakoululaissa säädettiin ryhmäkooksi kahdeksan oppilasta (Koukkunen 1982, 121; Kähkönen 1976, 103; Saine 2000, 109). Vasta vuonna 1983 voimaan tullut peruskoululaki toi ortodoksisen uskonnon tasa-arvoiseen 
asemaan enemmistön uskonnon opetuksen kanssa. Opetusryhmän minimikoko pieneni kolmeen eikä huoltajan tarvinnut enää erikseen vaatia ortodoksisen uskonnon opetusta lapselleen (Aikonen 1998, 415; Saine 2000, 175).

\section{Kehittyvä opetussuunnitelma}

Perusopetuksen opetussuunnitelman perusteiden (2004) mukaan ortodoksisen uskonnon opetuksen keskeinen tehtävä on ortodoksisen identiteetin vahvistaminen ja ylläpitäminen. Muutos on suuri verrattuna edellisiin peruskoulun opetussuunnitelman perusteisiin (1994), joiden mukaan ala-asteella "oppilaassa herätetään kiinnostusta ja myönteistä suhtautumista omaan kirkkoon, annetaan valmiuksia toimia aktiivisena seurakunnan jäsenenä sekä tuetaan hänen kasvuaan ortodoksikristittynä yhteistyössä kodin kanssa" ja yläasteella "opetuksessa tuetaan ja vahvistetaan oppilaan aktiiviseksi kirkon jäseneksi kasvamista antamalla tietoa oman seurakunnan toiminnasta ja ohjaamalla sen yhteyteen”. Perusteiden välillä, kymmenessä vuodessa, suomalainen yhteiskunta oli ehtinyt monikulttuuristua niin, ettei yhdeksänkymmentäluvun alun ilmauksia voitu enää käyttää puhuttaessa yhteiskunnan järjestämän uskonnon opetuksen tehtävästä.

Toinen selkeä muutos on muihin uskontoihin, erityisesti islamiin ja juutalaisuuteen tutustuminen jo alaluokilla (vrt. Pyysiäinen 2000, 15-17). Monikulttuuristumisen ja maailmanpoliittisen tilanteen lisäksi perusteena tälle muutokselle oli vuonna 2001 tehty perusopetuksen päättövaiheen uskonnon oppimistulosten arviointi, joka osoitti, että ortodoksisen uskonnon oppilaat tuntevat suuria maailmanuskontoja kohtalaisesti, uskontomaantiedettä heikosti ja islamia varsin huonosti (Rusama 2002, 91).

Muilta osin ortodoksisen uskonnon opetuksen sisällöt ovat säilyneet jokseenkin ennallaan. Keskeisiä sisältöjä vuosiluokilla 1-5 ovat kirkkovuosi ja pyhät ihmiset, kirkon jäsenenä toimiminen, Raamattu pyhänä kirjana, liturginen elämä sekä uskonoppi ja eettisyyteen kasvaminen. Vuosiluokkien 6-9 sisällöt ovat samoista aihepiireistä: Raamattu, kirkkohistoria, maailmanuskonnot, liturgiikka ja uskonoppi sekä etiikka. Oppisisällöt seuraavat yleisortodoksista perinnettä, sillä Kreikassa ja Kyproksella (jonka uskonnon opetussuunnitelma seuraa Kreikan suunnitelmaa) ortodoksisen uskonnon oppisisällöt ovat samoja. Tosin Suomessa maailmanuskontoja opetetaan niiden omista lähtökohdista käsin, toisin kuin Kreikassa (Spinder 1991, 200-201). 


\section{Yksi muiden joukossa, silti omaleimainen}

Vaikka ortodoksinen uskonto on yksi suomalaisen koulun virallisista ja pakollisista oppiaineista, se on monin tavoin erilainen ja omaleimainen. Omaleimaisuus näkyy opetuksen kokonaisvaltaisuudessa eli holistisuudessa. Oppisisällöt limittyvät toisiinsa ja integroivaa periaatetta sovelletaan spiraalimaisesti niin, että esimerkiksi kirkkovuoteen liittyvät aiheet toistuvat syventyen vuosittain. Yhdysryhmäopetuksessa onkin tärkeää, että koko ryhmällä on aika ajoin yhteinen teema. Toinen omaleimainen piirre on opetuksen liturgisen aineksen keskeisyys. Sen kautta voidaan kognitiivisesti vaativiakin aiheita käsitellä oppilaslähtöisesti ja kokemuksellisesti. Pari kertaa lukuvuodessa tehty kirkkomatka vahvistaa oppilaan uskonnollista identiteettiä. kun hän huomaa, että ortodoksioppilaita onkin enemmän kuin vain oman uskontoryhmän oppilaat (Aikonen 1998, 431-432; Huurinainen-Kosunen \& Lyhykäinen 2003, 166168.). Oppiaineen sisällöllinen omaleimaisuus on pedagogisesti perusteltua ja mahdollista, sillä opetukseen osallistuvat vain ortodoksiseen kirkkokuntaan kuuluvat tai muuten ortodoksisesta kulttuuritaustasta tulevat oppilaat eikä opetus voi näin olla vastoin heidän vakaumustaan.

Oppiaineen käytännönjärjestelyjä leimaa yhdysryhmä- ja vuorokurssiopetus. Monissa kouluissa kaikki ortodoksiseen uskontoon osallistuvat oppilaat opetetaan samassa ryhmässä. Oman lisänsä ryhmään tuovat maahanmuuttajat, joiden suomen kielen taito on vielä puutteellinen ja erityisoppilaat, jotka opiskelevat muuten omissa ryhmissään, mutta uskontoa integroidusti. Opettajalle tällainen ryhmä on haaste ja hän saakin yleensä käyttää kaiken pedagogisen tietämyksensä ja osaamisensa selvitäkseen opettamisesta. (Okulov 2003, 5255.) Ortodoksisten maahanmuuttajaoppilaiden määrä on kasvanut räjähdysmäisesti viimeisen vuosikymmen aikana. Pääasiassa heitä on tullut Venäjältä, Virosta, entisen Jugoslavian alueelta, Bulgariasta, Romaniasta, Ukrainasta ja Valko-Venäjältä. Avioliittojen myötä Suomeen on tullut myös kreikkalais- ja kyproslaistaustaisia lapsia. (Rusama 2002, 34.) Uskontotunti saattaa olla heille ainoa tuttu ja turvallisuutta tuova asia suomalaisessa koulussa sekä linkki entiseen kotimaahan.

Vaikka ortodoksisen uskonnon opetus on lainsäädännön tasolla tasavertaisessa asemassa enemmistön uskonnon opetuksen kanssa, ei käytännön tasolla olla vielä päästy siihen. Lukujärjestysongelmat ovat hyvin tavallisia. Jopa alakoululaisille tulee hyppytunteja uskontotunnin takia. Lisäksi opetusta keskitetään, jolloin pienetkin oppilaat voivat joutua kulkemaan toiselle koululle uskontotunnin takia. Opettajat ovat myös kokeneet, että koulu salaa ortodoksiseen uskontoon kuuluvia oppilaita, jottei opetusta tarvitsisi järjestää (Uittamo 2001, 10-14). Jotkut kunnat ovat venyttäneet laillisuuden rajoja niin, että se on johtanut kanteluun lääninhallitukselle. Näin tapahtui esimerkiksi Askolassa. 
Siellä ortodoksisen uskonnon lehtori teki hallintokantelun, jonka perusteena oli oppilaiden oikeus saada oman uskontonsa opetusta lainsäädännön ja ortodoksisen uskonnon opetussuunnitelman mukaisesti. Etelä-Suomen lääninhallitus antoi asiasta päätöksensä ja kehotti kuntaa saattamaan ortodoksisen uskonnon opetuksen lain säätämälle tasolle. (Etelä-Suomen lääninhallitus 29.12.2005 SVH2136A; Kantonen \& Lyhykäinen 2006.)

\section{Oman uskonnon opettajat}

Ortodoksisen uskonnon opetus on hyvässä asemassa muihin vähemmistöuskontoihin verrattuna oman opettajakoulutuksen vuoksi. Syyt ovat historialliset ja liittyvät myös osittain ortodoksisen kirkon asemaan Suomen toisena kansankirkkona. Ortodoksisen uskonnon aineenopettajia koulutetaan Joensuun yliopistossa. Ortodoksisen teologian opinnot voi suorittaa teologisessa tiedekunnassa ja opettajan pedagogiset opinnot kasvatustieteiden tiedekunnan soveltavan kasvatustieteen laitoksella. Lisäksi Joensuun yliopiston luokanopettajakoulutuksessa on $10 \%$ kiintiö ortodoksisia hakijoita varten. (Aikonen 1998, 420-421.) Ortodoksisen uskonnon opettajien koulutustaso on noussut kymmenen vuoden aikana huomattavasti. Aikosen $(1997,15)$ vuosina $1993-$ 1994 tekemän selvityksen mukaan vain noin $40 \%$ :lla opettajista oli opettajan kelpoisuus. Vastaava luku Rusaman $(2002,217)$ tutkimuksessa oli $43 \%$ ja Kuhasen (2005) kyselyssä noin 67 \%. Nämä luvut ovat vain viitteellisiä, mutta antavat kuitenkin käsityksen kehityksen suunnasta.

Koulutustason nousun myötä myös käsitys omasta opettajuudesta on muuttunut. Vuosien 1993-1994 selvityksessä opettajista 40\% ilmoitti kokevansa itsensä sekä kunnan että seurakunnan työntekijöiksi (Aikonen 1997, 49). Kuhasen (2005) kyselyssä vastaava luku oli 34 \%. Aikosen (1997) aineistossa 33 $\%$ ilmoitti olevansa vain kunnan työntekijöitä, kun taas Kuhasen materiaalissa (2005) luku oli jo $50 \%$. Luvut kuvastavat mielestäni oppiaineen kehitystä yhä enemmän oppiaineeksi muiden joukossa.

\section{Lopuksi}

Artikkelini tavoite on ollut osoittaa, että ortodoksisen uskonnon opetus raivannut tietä historian saatossa myös muiden vähemmistöjen uskonnon opetukselle. Tie on usein ollut kivikkoinen ja edelleenkin opetuksen käytännön järjestelyissä ilmenee epäkohtia. Jotta vähemmistöjen oman uskonnon opetusta voidaan kehittää edelleen lasten ja nuorten elämään liittyväksi yhä keskeisemmäksi oppiaineeksi niiden erityislaatu ja perinne huomioon ottaen, täytyisi käytännön 
asioiden olla jo nyt kunnossa. Merkki epätasa-arvoisesta asemasta on se, että vähemmistöuskontojen opetuksessa kipuillaan lukujärjestysteknisten ja riittämättömien opetustilojen kanssa, kun samalla muissa oppiaineissa voimavarat voidaan suunnata pedagogiseen kehitystyöhön ja projekteihin. Suomen katsomusopetusmalli on vähemmistöjen kannalta ylivertainen ja kuvastaa suomalaisen yhteiskunnan halua pitää huolta vähemmistöistään. Sen toivoisi vähitellen näkyvän myös käytännön toteutuksessa.

\section{Lähteet}

Aikonen, R. (1997). Ortodoksinen uskonnon opetus koulussa. Selvitys ortodoksista uskontoa opettavista opettajista ja opetustyöstä lukuvuonna 1993-94. Helsinki: Opetushallitus.

Aikonen, R. (1998). Ortodoksinen uskonnon opetus Suomessa. Teoksessa Pyysiäinen, M. \& Seppälä, J. (toim.), Uskonnonopetuksen käsikirja, 405-439. Helsinki: WSOY.

Etelä-Suomen lääninhallitus. Päätös SVH2136A 29.12.2005 ESLH-2004-05984/Op13. Hallintokantelu ortodoksisen uskonnon opetuksen järjestelyistä.

Huurinainen-Kosunen, A. \& Lyhykäinen, K. (2003). Ajankohtaista ortodoksisessa uskonnon opetuksessa 2000-luvun alussa. Teoksessa Aikonen, R. (toim.), Tarhurit 2001. Suomen Ortodoksisten Opettajain Liiton 50-vuotisjuhlakirja, 161-168. Helsinki: Suomen Ortodoksisten Opettajain Liitto.

Kantonen, M. \& Lyhykäinen, K. (2006). Oikeus oman uskonnon opetukseen. NäköalaUtsikt, $1-2$.

Koukkunen, H.(1982). Tuiskua ja tyventä. Suomen ortodoksinen kirkko 1918-1978. Heinävesi: Valamon luostari.

Kuhanen, J. (2005). Kysely ortodoksista uskontoa opettaville opettajille. Painamaton selvitys Ortodoksisen kirkollishallituksen Uskonnon opetuksen neuvottelukunnan käyttöön.

Kähkönen, E. (1976). Uskonnon opetuksen asema Suomen koulunuudistuksessa 19441970. Helsinki: Suomalainen Teologinen Kirjallisuusseura.

Okulov, S. (2003) Ortodoksisen uskonnon opetuksen haasteet 1990-luvulla - heterogeeniset ryhmät ja koulukohtaiset opetussuunnitelmat. Teoksessa Aikonen, R. (toim.). Tarhurit 2001. Suomen Ortodoksisten Opettajain Liiton 50-vuotisjuhlakirja, 50-57. Helsinki: Suomen Ortodoksisten Opettajain Liitto.

Peruskoulun opetussuunnitelman perusteet 1994. Helsinki: Opetushallitus.

Perusopetuksen opetussuunnitelman perusteet 2004. Helsinki: Opetushallitus.

Pyysiäinen, M. (2000). Yksi oppiaine, seitsemän opetussuunnitelmaa. Peruskoulun ja lukion opetushallituksen 1990-luvulla vahvistamien opetussuunnitelmien tunnustuksellinen luonne. Tutkimuksia 223. Helsinki: Helsingin yliopiston opettajankoulutuslaitos. 
Rusama, J. (2002). Uskonto, elämänkatsomustieto ja tapakasvatus. Oppimistulosten arviointi perusopetuksen päättövaiheessa 2001. Oppimistulosten arviointi 5/ 2002. Helsinki: Opetushallitus.

Saine, H. (2000). Uskonnon opetus Suomen oppivelvollisuuskoulussa 1900-luvulla. Turun yliopiston julkaisuja. Annales Universitatis Turkuensis. Turku: Turun yliopisto.

Spinder, H. (1991). Religionsunterricht in Europa. Eine Dokumentation der Intereuropean Commission on Church and School (ICCS). In Ohlemacher, J. (Hg.). Religion und Bildung in Europa, 183-227. Göttingen: Vandenhoeck \& Ruprecht.

Tomos. 6.7.1923. Timo Parrukoski (toim.), Ortodoksista kirkkokuntaa koskevia säädöksiä ja määräyksiä, 10-12. Kuopio: Ortodoksisen kirjallisuuden julkaisuneuvosto.

Uittamo, M. (2001). Uskontojen ja elämänkatsomustiedon opetuksesta Espoossa. Espoo: Espoon kaupunki. 



\title{
Children's Right to Religion: A Challenge to Religious Education'
}

\author{
Friedrich Schweitzer
}

\begin{abstract}
This chapter introduces the understanding that children's rights must also include their right to religion and to religious education. In critical conversation with the 1989 Convention on Children's Rights of the United Nations as well as with earlier declarations of such rights, the author maintains that there is a need to become clearer about children's religious rights and about their educational implications. From his point of view, all children have religious or spiritual potentials and needs. They ask questions of an ultimate kind that require (potentially) religious answers. Children cannot adequately be supported in their development if this dimension of their growing up and of their making sense of the world is excluded from education. Moreover, basing one's approach on children's rights also makes it necessary to follow a child-centered approach to religious education.
\end{abstract}

Keywords: children's rights, religious development, educations, parents' rights, educational approaches

\section{Introduction}

The claim that children have a right to religion is still somewhat new. In the past, religious education was based on requirements of the church or of the state. The church needs to introduce the younger generation to the religious tradition, and the state often hoped to achieve better citizens through the influence of religious education.

\footnotetext{
In an earlier version, this chapter was delivered as a lecture at Helsinki in October 2006. It is based on earlier publications, first of all my book Das Recht des Kindes auf Religion (Gütersloh: Gütersloher Verlagshaus 2000; Danish translation 2006) and my article: Children's Right to Religion and Spirituality: Legal, Educational, and Practical Perspectives, British Journal of Religious Education 27(2005), 103-114. In fact, the present text is a modified and expanded version of this article. I have also included smaller portions from F. Schweitzer/R. Boschki, What Children Need: Cooperative Religious Education in German Schools - Results from an Empirical Study, British Journal of Religious Education 26(2004), 33-44.
} 
Sometimes religious education is considered a right of the parents. The European Convention for the Protection of Human Rights and Fundamental Freedoms states in the Protocol of 1952, Article 2, concerning the right to education, that the State shall respect the right of parents to ensure such education and teaching in conformity with their own religious and philosophical convictions.

At the same time, there can be no doubt that children's rights and children's own perspectives have become more and more important for all fields of education. So-called child-centered approaches could once be considered a specialty and an experimental exception limited to so-called progressive institutions. In the meantime, child-centered approaches have come to be taken for granted throughout most European educational systems. It is understood that children should not only be the objects of education but that all education must respect them and treat them as autonomous subjects of their own right. Religious education is no exception to this. Contemporary approaches to religious education in many countries of the world clearly show a strong tendency towards taking children more seriously, giving them a stronger position in education and listening to what children have to say themselves rather than assuming that only adults can speak in the place of children. (Schweitzer 2006.)

Yet it remains true: Children's right to religion still appears to be a topic that is fairly new and not very common. Since it is still unusual to speak of children's right to religion I will first have to make clear what I mean with this right. The first part of my presentation is on children's right to religion. The second part is focussed on the connection between this right and religious education. Making children's right to religion the starting point does not only change the theoretical point of view but it also entails far-reaching implications for the practice of religious education itself.

\section{Children's Right to Religion and Spirituality}

Terminology always is a difficult matter. This is especially true when terms like 'religious' and 'spiritual' come into play or when concepts like 'nurture' and 'education' are used. These terms and their equivalents have different meanings in different languages, and even British and American English do not fully agree concerning the distinction between 'religious nurture' and 'religious education'. The distinction between nurture and education is now more or less taken for granted in the UK so that religious education has nothing to do with religious nurture. References to 'religious education' in the U.S., however, can be much broader and consequently can include settings like the family or the congregation. In the following, I do not intend to introduce a new 
terminology or to contribute to the elaboration of existing distinctions. I will use the term 'religious education' in a very broad sense, asking readers to keep in mind that my use of the term includes the dimension called spiritual as well as the religious, and that it refers to nurture as well as to education.

\section{Children and Religion in the 1989 United Nations Convention on the Rights of the Child}

The attempt to establish children's rights can be called one of the major twentieth century projects, with the 1989 United Nations Convention on the Rights of the Child being one of the final and decisive results. This convention is rightfully considered a milestone in the history of childhood and on the way towards more humane attitudes towards children. Yet while the issue of spiritual development has played a clear role in the struggle for children's rights all along, the 1989 Convention does not include a clear or sufficient reference to children's right to religious education.

The 1989 Convention does in fact refer to the spiritual rights of the child but this reference occurs not in the context of education but in the context of living standards. Article 27 states: the right of every child to a standard of living adequate for the child's physical, mental, spiritual, moral and social development.

Considering the earlier discussion of children's rights, this placement of children's spiritual rights in the context of living standards is somewhat surprising. It clearly runs against this earlier tradition. The very first declaration on children's rights - the 1924 Geneva Declaration on Protection de l'enfance (the protection of childhood) — only comprises five points. The first of them states that the child must be in position to 'develop normally, in material and spiritual respect'. (Dorsch 1994, 330.) In this case, as far as spiritual development is concerned, no distinction is made between standard of living and education. The spiritual development of the child is connected to both-material and educational provisions.

Compared to the more holistic 1924 statement, the 1989 Convention seems to be more narrow. The context in which spiritual rights are placed (article 27), is about issues like health care and social security. The placement primarily within the context of parental responsibilities and of the state's material aid to parents seems to imply that religious education is a private matter, most of all a parental concern and only indirectly for the wider community and the state or for the educational institutions maintained by the state.

This kind of critical reading of the 1989 Convention can be further supported by taking note of its other references to religion. The most important clause 
in this respect is article 14 which includes "the right of the child to freedom of thought, conscience and religion' (14.1) as well as the right of the parents 'to provide direction to the child' (14.2). This indicates that the Convention emphasizes the liberal idea of religious freedom which must be protected most of all against the state with its historically proven proclivity to safeguard its subjects' loyalty by determining their religious adherence. Moreover, it highlights the changing roles of parents and children within the family by clearly giving more weight to the freedom of the child. What is lacking, however, is a clear statement of children's right to religion and to religious education.

The critical view of the Convention must also refer to article 28 which states the 'right of the child to education' but does not mention spirituality or religion as part of this educational right. According to the Convention, the child has no legal claim to religious education. The 1989 Convention on children's rights recognizes the child's spiritual development as an essential aspect but it falls short of the necessary consequences concerning education. It does not require the state to provide the educational opportunities necessary for supporting the child in his or her spiritual development. (Hull 1998, 59-62.)

\section{Educational Perspectives on Children's Right to Religion}

Speaking of children's right to religion or spirituality implies much more than the legal or organizational provision of religious education as part of the curriculum (as important as this may be). It also refers to attitudes and convictions of parents and teachers who, from the perspective of this right, must come to recognize that children need their support, affirmation, and guidance in respect to religion no less than in other areas of nurture and education. In the absence of such attitudes and convictions, legal guarantees will not have any helpful consequences, especially not in the field of religious education which, by its very nature, is concerned with matters of personal convictions.

Moreover, recognizing that religious nurture and education are in fact a right of the child forces us to reconsider most of the traditional understandings in this field. Traditionally, the aims and contents of religious education were determined by authorities and not by the needs of children. To say it again: Such authorities could be the parents themselves (whose right 'to provide direction to the child' is again asserted in the 1989 Convention in article 14.2). Or it was - and is - the authority of a religious tradition, of a church or religious community, or even the authority of the state with the attempt of inculcating some kind of civic values. Opposed to all views deriving the need for religious education from such authorities, a children's rights approach will make the child its first point of reference. The question what children need, 
becomes an important starting point, and the answer to this question can no longer be given by adults who presuppose that it is them who always know best about the true needs of children. Even if children, at least during the first years of life, cannot speak for themselves, we must be prepared to learn how to carefully observe, and to intensively listen to, what they may tell us in their special ways of communicating. We must be prepared that even young people might have something meaningful to contribute to their own religious development and education.

I am not arguing here for a return to the romanticist visions of the naively child-centered approaches of early twentieth century which, like in the well known case of Ellen Key, the Swedish author of the Century of Childhood published in 1900, claim that children should exclusively discover their own religion without any adult interference. (Key 1978.)

I am also not claiming that we should forget about all religious traditions and authoritative sources like the Bible in order to invent a better religion. This kind of romanticist attitude amounts to a naïve view of children and of religion which is no less distortive than the views which it tries to replace. What is needed instead is a very different attitude towards children who should be respected as partners in dialogue even if they continue to need our care and support. The choice is not between the completely dependent child and the completely autonomous child. Rather, what counts is the continued combination and balance between perfect respect for the child and the need to make responsible choices for the child.

In sum, the reference to children's right to religion should be understood in legal as well as in educational terms, and it must translate into educational attitudes and approaches which take children seriously as active centers of experience rather than merely as objects of education.

This kind of understanding of children's rights follows the lead of earlier educationists like the Polish-Jewish physician and educator Janusz Korczak who, as a pioneer in the field of children's rights in the 1920s, tried to translate the claims of the children's rights movement into educational models. One of his most famous books is about The Child's Right to Respect-which indicates the attitude which Korczak wanted to achieve. (Korczak 1970.) Children should no longer be treated as less valuable and as less respectable than adults. Their needs should be taken very seriously, their feelings should never be disrespected, and their voices should no longer be silenced. In this manner, Korczak carved out a new type of philosophy of education in the name of the child (and his death in a German concentration camp, at the side of the foster children living with him, can be seen as the factual corollary of his powerful writings). 
Consequently, one of the main tasks in the context of religious nurture and education is to convince parents and educators that children have a right to religion. In my own work in the field of religious development and education, I have tried to establish the understanding that there are questions which arise in the life of all children and which possess an at least potentially religious meaning (Schweitzer 2000.) These questions are sometimes called the 'big questions' because they refer to matters of life and death or to the meaning of life. They indicate that the spiritual or religious dimension is indeed a fundamental dimension in the process of growing up and that this dimension should not be neglected.

Over the years, in my empirical as well as historical and hermeneutical research on religious development and education, I have identified five such questions of potential religious meaning. They include questions which children pose to us explicitly. But they also include questions which children are for us and which they confront us with through their being with us as their parents or educators.

The first of these questions refers to death and dying. All children encounter this question sooner or later, and many of them encounter it all too soon in this world of violence and aggression. Even with the most protected childhood, children will eventually come across the dead bird on their way home from school or they will learn of the death of their friend's relative and maybe even be confronted with the death of a parent.

This is not the place for an extended discussion of the different ways in which children deal with the issue of death and dying or of the attitudes that different cultures and religions may include. Yet some examples may be helpful - not for proving my point but in terms of illustration. The following conversation between a German child at the age of approximately 5 years with his father indicates what questions can ensue from children's encounter with death and dying, at least within a broadly Christian setting: (Taken from Biesinger 1994.)

Child: All people die, right father?

Father: All people die.

Child: But you will not die. (Pause) Then I am so alone.

Father: Of course we will also die. But now we are still alive.

Child: And who decides when you die? (Pause) Does God make this decision?

Father: God decides. You know, when one is old, maybe one does not want to live any longer.

Child: But you are old already. And where shall I go?

Father: God will send you to a new father.

Child: You will not die before I grow up, and even one day later. And after you die, I will go to my grandmother. 
This conversation shows how a child brings up the question of death and dying. It is important for this child to think about what happens if his parents die. Death appears to be a social threat in the first place, that is, losing the people the child has to depend on. The father is taken by surprise but tries to find answers that the child can understand and accept. In the end, however, the father's suggestion of God sending the child to a new father which is meant to comfort the child, fails to meet the child's actual needs. A new father cannot be a comfort for the child because this father would exactly imply what the child seems to fear most - being with people who are not familiar to the child. It is the child himself who, in the end, finds a creative solution: 'And after you die, I will go to my grandmother'. As opposed to the 'new father', the idea of the grandmother is comforting because she is familiar and obviously trustworthy to the child.

This example suggests that children have a need to include the question of death and dying with their conversations with parents or educators. For them, such questions are not only a private matter to be pondered secretly when they are by themselves. They want to know what the adults around them think about it. They are looking for support, affirmation, and guidance. Not addressing this need would clearly fail the child in an important respect.

Once I used this story in a conversation with a systematic theologian. $\mathrm{He}$ was wondering if the example does not prove - against my intentions - that children do in fact not need religion because, for children, death and dying are not related to any kind of transcendence. The immanent comfort of having a grandmother is enough for the child.

I do not think that this objection is valid. Let us consider another example that comes from the book Do Children Need Religion? by Martha Fay, a mother and journalist in the United States. (Fay 1993.) Martha Fay relates how her three-year old daughter Anna started asking questions about death and dying after her grandmother died. Anna wants to know why her grandmother had to die, and no reference to old age or failing health seems to be a sufficient answer to her repeated questions. Anna wants to know what 'dead' really means and where 'people go when they die'. It is fascinating to read how the mother slowly but surely comes to understand that Anna's questions are not about factual explanations. Anna wants to know the meaning of death. She is not only interest in how people die but also why they have to die. Yet Anna's questions remain a challenge for the adults. Martha Fay continues:

Nor, we soon realized, would her father and I long remain her exclusive informants. Within a few months, her friend Ian's grandmother had also died, but unlike Nanny [Anna's grandmother; F.S.], this lucky woman, according to her grandson, had gone straight to heaven, which turned out to be right where I had left it as a child, 
and where Anna-hearing about it, as far as we knew, for the first time-seemed to think it properly belonged: directly overhead, out of sight behind the clouds.

This example indicates that we can answer children's questions about death and dying without any reference to religion or transcendence, for example, by limiting our responses to so-called rational or factual explanations. But it is also clear that such explanations fall short of what many children are interested in. Moreover, we should also wonder what kind of worldview we are conveying to them through our answers.

Non-religious answers tend to emphasize that humans just have to die, sooner or later. This is just 'how it is'. While this is certainly true in some respects, children may easily draw additional conclusions from this kind of response and, through this, the response may actually turn out not to strengthen rationality but fatalism. If there is no room for hope and wishes in the face of death, if there is no room for anger and disappointment but just for detached ('rational'?) acceptance of what has happened because this is 'how it is' - what else in the world is like that? Is everything predetermined and is there no room for feelings and longings because reality just demands compliance?

Some educators consider questions relating to death and dying to be too traditional and too narrow in order to serve as a starting point for religious education. Educators who explicitly want to follow the Christian faith, sometimes have even more far-reaching objections. According to their convictions, the Christian faith is not about death but it is about life. Consequently, they are looking for a different rationale for religious education. So let us at least briefly look into a second big question that children ask: Why do other children call God Allah or some other foreign name?

This question obviously arises from the experience of religious plurality that is becoming more and more common for many children in the western world. (Schweitzer 2004.) They grow up together with children who have different denominational and religious backgrounds. They come to realize that the ways in which their parents and families believe, are not the only possible ways. Not even God has the same name with all people!

Some parents and educators argue that plurality makes religious education very difficult. Yet I am convinced that plurality also makes religious education even more necessary. Children always have to gain a sense of belonging, and they want to know about what they are and how their religious affiliation relates to other affiliations.

In one of our studies on dialogical religious education in grade schools we observed that denominational or religious identities can be quite puzzling for children. ${ }^{2}$ When we asked the children how one becomes Protestant or Catho-

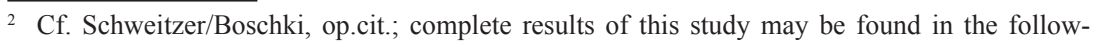


lic, they had fascinating explanations to offer. Especially at the beginning of first grade, they are often unclear and uncertain about the origins of different denominational affiliations. In some of the interviews the children refer to baptism and the church but it is much more impressive to listen to their own 'theories' and to the views developed by the children themselves. According to their views, denominational affiliation goes back to different processes or presuppositions which the children seem to have 'invented' themselves: God says it, the minister says it, the parents say it,..., it is taught, it can only be seen after two or three years, one is born into a church, it says on the baptismal fount etc. One child assumes that it depends on the year of birth:

Student: $\quad$ They are born in that year.

Interviewer: In which year?

Student: 1999 maybe, or 1998-1991?

Interviewer: And who then is Catholic and who is Protestant?

Student: If it is an uneven number, the child is maybe Protestant, if it is an even number...

Another type of explanation which we encountered frequently, has to do with the purposes and aims which the children see connected with the distinction between the denominations. Just like children tend to see the world as ordered according to purposes and aims (Piaget's so-called finalism), they also explain the existence of different denominations by referring to such purposes and aims (so that there is enough space in church, otherwise it would be too crowded etc.)

Taking these observations concerning denominational and religious affiliations and identities together, we can say that coming to terms with such affiliations can be seen as part of the children's attempts of understanding the world and that they are part of an education which aims at supporting children in these attempts. Children encounter terms like Protestant and Catholic in the same way they encounter other terms, names or institutions in society. In many cases children form their own interpretations and explanations of what such things may mean. In our view, it is part of the task of primary education to support children in this respect. In this context, the question of the children's own affiliation and belonging plays an important role as well.

In one of the interviews, the question was discussed if denominational backgrounds play a role for the children's choice of friends. For one of the

ing books: F. Schweitzer/A. Biesinger et al. (2002), Gemeinsamkeiten stärken - Unterschieden gerecht werden. Erfahrungen und Perspektiven zum konfessionell-kooperativen Religionsunterricht (Freiburg \& Gütersloh. Herder \& Gütersloher Verlagshaus); Schweitzer/A. Biesinger et al. (2006), Dialogischer Religionsunterricht. Analyse und Praxis konfessionell-kooperativen Religionsunterrichts im Jugendalter (Freiburg/Herder). 
children it was clear that it does "not play any role" in the case of her "best friend" if "she happens to be Protestant or Catholic". She expressed her view that it is not important what she is like "on the outside" but only what she is like "inside". From this statement, the following conversation developed:

Interviewer: Does being Catholic or Protestant belong to what is outside or to what is inside?

First student: Outside.

Second student: Outside and inside because it somehow...

Third student: Inside... It belongs to what is inside, yes... As a Protestant one somehow thinks, somehow a little bit less. Or more or less, or the same.

First student: Same.

Third student: ... or whatever. But one is different. One is different inside... One does more crazy things or...

The conversation continues with references to the fact that, at birth, one does not know what one is, and that all people are different from each other through their outer appearance but that they may also be different because they think in different ways. Slowly but surely the children seem to be sorting out the meanings of inner and outer differences. Through this, they actively develop their concept of the human person and of its different sides - a true educational achievement.

Concerning children's right to religion such examples highlight the need to address issues of religious affiliation and belonging. In plural environments children inevitably encounter different denominations and religions. Education should not leave them without support in coming to terms with such experiences, especially if education should contribute to peace and tolerance- $\mathrm{a}$ question that I will come back to at the end of this chapter.

Space does not allow for a more detailed elaboration on the three other questions which, in my view, can be a basis for an educational understanding of the child's right to religion. So I limit myself to at least mentioning them:

- Why be moral in a world which is not moral?

- Who am I and who am I allowed to be? Who can sponsor my identity?

- Who (or what) is God?

All these questions can be answered in an exclusively rational or factual manner. But for many children, these questions have a different ring, neither mechanic nor rational, neither material nor only pragmatic. Such questions indicate, for the children who pose them or for the adults who see themselves confronted with such questions through the very existence of the children, that there is a spiritual or religious dimension involved in the process of growing 
up. And children want this dimension to be addressed openly and directly, no less than other mysteries which they encounter in the world.

\section{Consequences for Religious Education}

Arguing for children's right to religion has far-reaching practical implications. These implications refer to the place of religious nurture and education within the educational ecology of a society, and they also refer to the ways in which religious nurture and education should address the child.

Let me come back to the beginning of this chapter: Traditionally, religious education was not perceived as a right of the child. Rather, philosophers as well as politicians considered it a right of the state or of the government which, according to this view, is entitled to the loyalty of the citizens as its obedient subjects. The most famous example is Jean-Jacques Rousseau's (1762) plea for some kind of civil religion which is to furnish the shared values and norms that are necessary for the maintenance of societal order. (Rousseau 1762.) No less impressive are the repeated statements of German nineteenth century kings and Kaisers demanding that school religious education foster the kind of piety which makes the child honor the paternal and god-like authority of the emperor. $^{3}$

Next to the state it was the churches that made their claims to religious education. According to their understanding, religious education was a right of the churches based on baptism and it had to be in line with the doctrines of the churches. Again, the educational rights of the child were not considered the basis of religious education.

While none of these traditional views remained unchanged in twentieth century, among others, under the influence of modern democracy, modern education, and the children's rights movement, there still was - and maybe still is - a basic understanding that religious education should contribute to civic loyalties and should follow the instructions of the church. At the same time, given today's multicultural societies and given the ideas of critical education and of autonomy as the aim of education, this has become a difficult legacy. The more different cultures and religions are present in society, the less the state can rely on any one of them for support. Religion is no longer seen as a unifying bond. Instead it is often considered to be divisive. Consequently, the traditional rationale for religious education becomes more and more tenuous, with critical education questioning its status even further.

For example, also concerning the next paragraph, cf. K.E. Nipkow/F. Schweitzer (1994) (eds.) Religionspädagogik. Texte zur evangelischen Erziehungs- und Bildungsverantwortung seit der Reformation. Vol. 2/1: 19. und 20. Jahrhundert (Gütersloh, Gütersloher Verlagshaus). 
In this situation, basing religious education on the child's own rights becomes an important possibility for at least two reasons.

First, religious educators who consider children's rights as the basis for their work, also do justice to today's view of the child as a person of his or her own rights. Religious education should not fulfil the needs of adults vis-à-vis the child - it should acknowledge and affirm what is important for the children themselves.

Second, children's rights are the only basis strong enough to function as a rationale for religious education after the respective claims of state and church have lost much of their acceptance and plausibility. At least in the long run, only a religious education based on children's rights will be convincing for parents, educators, and politicians. In many cases, it is only this kind of education based on the needs of the child that they will feel committed to.

If it is true that religious education is a right of the child, it makes sense to argue that no educational ecology can be complete or comprehensive as long as it does not include religious education. There will always be different possibilities of how families, congregations, kindergartens, schools, or other programs for children actually try to do justice to this task. Yet the decisive question to be asked in all cases is if the children will have sufficient access to the support, stimulation, and guidance needed for healthy development. In this sense, the reference to children's right to religion can become a critical question to be raised in relationship to any given educational setting. For RE in state schools this implies that the demand for educational neutrality should not be considered a valid argument against RE. If children have a right to religion, the school has to do justice to this right. Children in countries like France or the United States that have no RE in state schools, clearly are at a disadvantage in this respect.

So far, I have left the question aside what kind of religious education children should be given and how it should be taught. Yet will any kind of religious education be equally sufficient and beneficial for the child? This is a difficult question because there are many different answers given not only by different religious traditions but often even within one and the same tradition. Clearly, no approach based on democracy and no approach based on children's rights or human rights should attempt to determine the contents and directions of religious education. This would be a contradiction in terms because, in a democracy, religious convictions cannot be determined by law. Yet it also does not make sense to argue for children's right to religious education while adhering to a style of authoritarian inculcation or while propagating types of religious education that are detrimental for children. Such extreme examples indicate that a children's rights approach includes criteria for the shape of RE as well. 
Non-authoritarian and child-centered approaches to religious education clearly have an affinity to a children's rights approach. In my own work, I have tried to develop such approaches for different age groups, among others in close conversation with developmental psychology and other kinds of research which allow for a better understanding of what children need. Many colleagues in different countries are following the same lead, sometimes in the tradition of developmental psychology, sometimes in the footsteps of educators like Korczak, and sometimes creating new visions of spiritual development.

Only a type of religious education which does justice to the needs of children as well as to their autonomy, can rightfully appeal to children's rights. Any attempt to justify authoritarian types of education or of indoctrination by drawing upon children's rights, must be vain. The attempt of establishing children's right to religion must go hand in hand with the advancement of this right in the theory and praxis of religious education.

Another argument concerns the dialogical nature of religious education in school. It can be reasonably argued that democratic education requires a type of RE that introduces children to the need for dialogue between different religious groups and orientations, be it within Christianity with its different traditions of Orthodoxy, Roman Catholicism, and Protestantism, or be it between different religions. (E.g. Jackson 2004.) In our work at Tübingen, we have been able to study dialogical RE empirically, for the most part with Protestant and Roman-Catholic children but also with children without religious affiliation and with some Muslim children. (E.g. Schweitzer \& Boschki 2002; Schweitzer \& Boschki 2006.)

Our results are not representative but nevertheless have important implications for the future shape of RE. Our results suggest that children's right to religion and religious education cannot be fulfilled without making space for religious commitment. In this sense, the demand for educational neutrality should not be taken to mean that there should be no place for truth claims and convictions that grow out of a certain religious tradition.

Following the approach that gives special emphasis to the perspective and needs of the children, I want to suggest some answers to the question what children need in terms of RE. Four arguments emerge from our research:

(1) Children need a type of RE that supports their understanding of religious affiliation as part of their making sense of the world, and that includes the question of their own belonging. In part, this task is an immediate implication of the general educational task especially of primary education, i.e., to support the children's understanding of the world.

(2) Coming to terms with the issue of belonging is not only an abstract or cognitive challenge. Belonging is mediated, especially for children, by identifications, usually with adults. Consequently, RE should give chil- 
dren a chance to be with adults with whom they can identify in terms of religious belonging.

(3) Beyond the question of identification there is the issue of competence. Children are entitled to a presentation of religious traditions which is based on true familiarity with the respective tradition. In our study, it was the children themselves who raised this question. They observed that one teacher is more familiar with Protestantism while another teacher is a specialist for Catholicism. This is why some of the children explicitly wished for the opportunity of having different teachers, depending on the topics.

(4) The traditional type of separate RE clearly is not enough. If children are to come to terms with religious diversity and also for the sake of peace and tolerance, children need a type of RE which helps them to develop positive and appreciative ways of being with other children from culturally and religiously different backgrounds. This is why RE can not be limited to the task of supporting identifications but must also include personal encounters with others who come from such backgrounds.

My focus in this chapter has been on general reasons for children's right to religion. Such reasons are important for public discourses. Yet in conclusion I want to remind readers that churches and Christian educators have a special obligation to stand up for children's rights. There is a clear theological and biblical rationale for children's right to religion. I am referring, for example, to the well-known stories from Mk 9 and 10 where Jesus puts a child in the midst of his disciples and where he tells them that children have special access to him as well as to the kingdom of God.

\section{References}

Biesinger. A. (1994). Kinder nicht um Gott betrügen. Anstiftungen für Mütter und Väte. Freiburg: Herder.

Dorsch, G. (1994). Die Konvention der Vereinten Nationen über die Rechte des Kindes. Berlin: Duncker \& Humblot.

Fay, M. (1993). Do Children Need Religion? How Parents Today Are Thinking About the Big Questions. New York: Pantheon.

Hull, J. M. (1998). Religious Education and the Spiritual Rights of Children In Hull, J. M. (ed.), Utopian Whispers: Moral, Religious and Spiritual Values in School, 59-62. Norwich: RMEP.

Jackson, R. (2004). Rethinking Religious Education and Plurality: Issues in Diversity and Pedagogy. London/New York: RoutledgeFalmer.

Key, E. (1978). Das Jahrhundert des Kindes. Königstein: Athenäum. 
Korczak, J. (1970). Das Recht des Kindes auf Achtung. Göttingen: Vandenhoeck \& Ruprecht.

Nipkow, K. E. \& Schweitzer, F. (1994). (eds.), Religionspädagogik. Texte zur evangelischen Erziehungs- und Bildungsverantwortung seit der Reformation. Vol. 2/1: 19. und 20. Jahrhundert. Gütersloh: Gütersloher Verlagshaus.

Schweitzer, F. (2000). Das Recht des Kindes auf Religion. Gütersloh: Gütersloher Verlagshaus.

Schweitzer, F. (2004). The Postmodern Life Cycle: Challenges for Church and Theology. St. Louis: Chalice Press.

Schweitzer, F. (2006). Religionspädagogik. Gütersloh: Gütersloher Verlagshaus.

Schweitzer, F. \& Biesinger, A. (2002). Gemeinsamkeiten stärken - Unterschieden gerecht werden. Erfahrungen und Perspektiven zum konfessionell-kooperativen Religionsunterrich. Freiburg \& Gütersloh: Herder \& Gütersloher Verlagshaus.

Schweitzer, F. \& Biesinger, A. (2006). Dialogischer Religionsunterricht. Analyse und Praxis konfessionell-kooperativen Religionsunterrichts im Jugendalter. Freiburg: Herder. 



\title{
Laadukas katsomusaineiden opetus
}

\author{
Arto Kallioniemi
}

Tiivistelmä

Artikkelissa tarkastellaan muuttuvaa kasvatuksen yhteiskunnallista kontekstia, jossa keskeisiä muutostekijöitä ovat: 1. integraatio ja alueellistuminen, 2. ongelmien globaalisuus, 3. tasa-arvon väheneminen ja lisääntyminen: siirtyminen uusliberalistiseen yhteiskuntaan, 4. arvoristiriidat, 5. postmodernismi ja sen seuraukset sekä sille vastakkaiset voimat, 6. informaatioteknologian kehitys, 7. välinpitämättömyys, 8. fundamentalismi ja 9. muutosten kohtaaminen. Tämän jälkeen pohditaan katsomusaineiden opettajan tehtävää yleissivistävässä koulussa sekä tarkastellaan, mitä katsomuksellisella ja uskonnollisella yleissivistyksellä tarkoitetaan. Artikkelissa pohditaan saksalaisen professori Schweitzerin kehittämiä uskonnon opetuksen kansainvälisiä kriteereitä sekä tarkastellaan suomaista katsomusaineiden opetusta niiden näkökulmasta. Artikkelissa esitellään katsomusaineiden opetuksen kehittyvää toimintakulttuuria. Tämän tarkastelussa liitytään sosiokulttuurisen ja kokemuksellisen oppimisen teoriaan. Artikkelissa luodaan katsaus katsomusaineiden opettajan professionaalisuuteen ja ammattietiikkaan. Lopuksi tarkastellaan katsomusaineiden opettajan tehtävää kulttuurisena sivistystyöntekijänä, jonka ammatin keskeisiä ydinosaamisalueina ovat eri uskontojen ja katsomusten kulttuuriperinnön ja etiikan opetus. Keskeisenä käsitteenä katsomusaineiden opettajan ammatissa ovat sitoutuminen klassisen humanismin pohjalta nouseviin sivistyksen ulottuvuuksiin: totuus, hyvyys ja kauneus sekä kristinuskon sisältämään lähimmäisenrakkauteen ja uuden ajan keskeiseen perusarvoon vapauteen.

Avainsanat: katsomusaineiden opetus, katsomusaineiden toimintakulttuuri, uskonnon ja elämänkatsomustiedon opettajan ammatti ja etiikka

\section{Muuttuva kasvatuksen konteksti}

Minkälaista on laadukas katsomusaineiden opetus? Suomessa ei ole juuri pohdittu, mitä on katsomusaineiden opetuksen laatu. Katsomusaineilla tarkoitetaan yleissivistävässä koulussa uskontoa, elämänkatsomustietoa ja filosofiaa. Rusaman (2002) raportissa tarkasteltiin 2000-luvun alussa, mitä oppilaat olivat oppineet uskonnon ja elämänkatsomustiedon opetuksessa. Laadun tarkastelu kyseisessä raportissa jäi kuitenkin melko pitkälle formaalisten oppimistulosten 
tarkasteluksi, eikä porautunut syvällisesti katsomusopetuksen laadullisiin kysymyksiin. Opetussuunnitelman tasolla katsomusaineiden opetukseen sisältyy vahva yleissivistävä tiedollinen ja henkistä kasvua tukeva aines. Näiden oppiaineiden opetussuunnitelmien tavoitteet eivät ole puhtaasti tiedollisia, vaan katsomusaineiden opetuksen luonteeseen kuuluu ikään kuin sisään rakennettuna vahva henkisen kasvun, elämän, erilaisuuden ja suvaitsevaisuuden elementti. (Ks. esim. Perusopetuksen opetussuunnitelman perusteet 2004.)

Katsomusaineiden opetus eroaa muista koulun oppiaineista esimerkiksi siinä, että niiden opetuksessa otetaan huomioon lasten ja heidän kotiensa uskonnollinen ja maailmankatsomuksellinen tilanne. Laadukas katsomusaineiden opetus käsitteenä liittyy opetuksen etiikkaan ja arvokysymyksiin sekä katsomusaineiden opetuksen kehittyvään toimintakulttuuriin. Katsomusaineiden opetuksessa on aina kysymys siitä, miten opetus ja opettaja vaikuttavat kasvavaan lapseen ja nuoreen (vrt. Kansanen 1996, 16-17).

Kasvatuksen ja opetuksen konteksti, ympäristö, jossa katsomuskasvatus toteutuu, on muuttunut viime vuosikymmeninä merkittävästi. Seuraavat tekijät ovat muuttuvan yhteiskunnan keskeisiä tekijöitä:

1. Integraatio ja alueellisuus

2. Ongelmien globaalisuus

3. Tasa-arvon väheneminen ja lisääntyminen: siirtyminen uusliberalistiseen yhteiskuntaan

4. Arvoristiriidat

5. Postmodernismi ja sen seuraukset ja sille vastakkaiset voimat

6. Informaatioteknologian kehitys

7. Välinpitämättömyys

8. Fundamentalismi

9. Muutosten kohtaaminen

Kaikki muutostekijät koskevat myös katsomusaineiden opetusta. Katsomusaineiden opetukseen liittyy erilaisten uskomusten, katsomusten ja elämäntapojen tarkastelua. Etiikka ja moraali sekä kasvatus ovat keskeinen osa näiden aineiden opetusta. Kaikki yhteiskunnan muutosprosessit sisältävät elementtejä, jotka laadukkaassa katsomusaineiden opetuksessa on huomioitava. (Vrt. Kallioniemi 2005a, 11-17.)

Katsomusaineiden opettajana toimiminen yleissivistävässä koulussa on syvästi eettinen tehtävä, jonka vaikutukset ulottuvat vuosikymmenien päähän. Katsomusaineiden opetus tähtää katsomuksellisen ja uskonnollisen yleissivistyksen saavuttamiseen. Yleissivistystä ei ole enää viime vuosikymmeninä nähty päämääräksi vaan prosessiksi. Yleissivistys on dynaaminen prosessi, jonka pohjalta yksilö pystyy orientoitumaan yhä muuttuvissa tulevaisuuden olosuhteissa. Katsomusaineet yleissivistävän koulun oppiaineina tarjoavat oman 
näkökulmansa humanistis-yhteiskunnalliseen yleissivistykseen ja kulttuuriseen lukutaitoon. Kun tarkoitetaan yleissivistyksen eri alueiden hyötykäyttöä, voidaan puhua näistä alueista erilaisina "lukutaitoina". Henkilöllä on jonkin alan lukutaito, mikäli hän pystyy arkiosaamisen tasolla käyttämään hyväkseen aluetta. Uskonto tarjoaa kulttuuriseen lukutaitoon oman spesifin näkökulmansa: uskonnollisen kulttuurin ja symbolien lukutaidon, kun taas elämänkatsomustiedon näkökulma on hieman erilainen.

Kulttuurinen lukutaito voidaan ymmärtää esimerkiksi kulttuurin kielellisiksi symboleiksi ja niihin sisältyviksi merkityksiksi, joiden avulla kulttuurin jäsenet kommunikoivat keskenään. Toisaalta taas kulttuurinen lukutaito ei koostu pelkästään kokoelmasta kirjoitettuja symboleita, vaan kulttuurinen lukutaito voidaan nähdä kompleksiseksi systeemiksi, joka koostuu merkityksistä, arvoista, uskomuksista ja ajattelutavoista, joiden avulla ihmiset ymmärtävät toisiaan ja voivat kommunikoida keskenään. (Hirsch 1988; Smith 1992; ks. myös Välijärvi 1993, 4-5.)

Näin katsomusaineiden edustamat kulttuurisen lukutaidon komponentit sisältävät lukuisia erilaisia merkityksiä, arvoja, uskomuksia ja ajattelutapoja, joiden avulla opitaan ymmärtämään itseä ja toisia, erityisesti uskonnon ja katsomusten tiedon alaan liittyvissä kysymyksissä. Kulttuurisen lukutaidon komponentit antavat valmiuksia ymmärtää erilaisia ajassa liikkuvia maailmankatsomuksia ja ideologisia virtauksia sekä avaavat kykyä reflektoida niiden äärellä. Katsomusaineiden opetukseen liittyvät kulttuurisen lukutaidon komponentit sisältävät myös laajan arvoulottuvuuden, joka mahdollistaa erilaisten elämäntapojen ja arvojen reflektoinnin. (Kallioniemi 1995, 112-114; 2000, 26-27.)

Uskonnollisen ja katsomuksellisen yleissivistyksen ohella viime vuosina kansainvälisessä uskonnon didaktisessa tutkimuksessa on alettu käyttää käsitettä uskonnollinen kompetenssi, joka tulee käsitteenä lähelle uskonnollista ja katsomuksellista yleissivistystä, jolla tarkoitetaan monipuolista uskontojen, katsomusten sekä symbolien lukutaitoa (esim. Heimbrock et al. 2001). Uskonnollinen kompetenssi -käsitteen käyttö perustuu ajatukseen, että uskontoon liittyvä opetus ja oppiminen kuuluvat kokonaisuudessaan ihmisen kasvuun ja kehittymiseen. Uskonnollinen kompetenssi tarkoittaa kykyä käsitellä omaa uskonnollisuuttaan ja sen erilaisia ulottuvuuksia yhdistettynä dynaamisesti elämänhistoriaan vastuullisella tavalla, mutta myös kykyä arvostaa toisten erilaisia uskonnollisia käsityksiä ja katsomuksia. Uskonnollinen kompetenssi käsittää muun muassa aktiivisen kyvyn toleranssiin, kyvyn toimia eettisesti orientoituneella tavalla sekä valmiuden dialogiin uskonnollisissa kysymyksissä. Se käsittää myös kyvyn käsitellä uskonnollista pluralismia ja eroja konstruktiivisella tavalla. (Heimbrock et al. 2001, 9.) 
Tutkimuksissa on harvoin tarkasteltu katsomusaineiden opetuksen laatua. Näiden oppiaineiden opetuksessa on viime kädessä kysymys niin monitasoisista ja monisäikeisistä ilmiöistä, että katsomusaineiden opetuksen laadun tarkastelu on vaikea ja vaativa tehtävä. Viime vuosina ovat kansainväliset opetuksen ja oppimisen laatuun liittyvät arvioinnit lisääntyneet merkittävästi, esimerkiksi PISA-arviointi. Arviointien yhteydessä on selvitetty oppilaiden erilaisia kykyjä ja taitoja. Varsin usein nämä arvioinnit ovat kohdistuneet niin sanottuihin avaintaitoihin, joiksi on usein määritelty esimerkiksi luku- ja kirjoitustaito sekä suullinen kommunikointi äidinkielellä ja jollakin vieraalla kielellä, matematiikan ja luonnontieteiden osaaminen, yhteiskunnallinen tietoisuus ja aktiivisuus, tietotekniikan tarkoituksen- ja tilanteenmukainen käyttö, opiskelun ja oppimisen taidot, sosiaaliset taidot sekä ryhmässä työskentelyn ja verkottumisen taidot. (Linnakylä \& Välijärvi 2005, 66-67.) Katsomusaineiden opetusta ja oppimista ei ole juuri kansainvälisesti arvioitu. Eri maiden katsomusopetusjärjestelmät ja niissä toteutettavat opetussuunnitelmat eroavat toisistaan niin merkittävällä tavalla, että niissä tapahtuvan oppimisen kansainvälinen arviointi ja vertailu eivät ole mahdollisia.

\section{Kansainväliset kriteerit}

Saksalainen professori Friedrich Schweitzer (2002) on kehittänyt uskonnon opetukselle kansainvälisiä kriteereitä. Viime vuosikymmeninä kansainvälistyminen on noussut yhdeksi keskeiseksi uskonnon opetuksen kysymykseksi. Globalisaatio ja Euroopan yhteisön laajentuminen ovat tehneet välttämättömiksi tarkastella eri maissa toteutettuja uskonnon opetuksen malleja ja muotoja poliittisten järjestelmien, kansallisten ja kansainvälisten konfliktien näkökulmasta. Kriteerien tavoitteena on kuvata uskonnon opetuksen luonnetta ja olemusta tavalla, josta alan kansainväliset asiantuntijat ovat yksimielisiä. Niiden tehtävänä on toimia lähtökohtana hyvän käytännön toteuttamiselle uskonnon opetuksessa. Kriteerit ovat syntyneet tarkastelemalla uskonnon opetuksen tutkimuksessa ja alan kansainvälisessä kirjallisuudessa viime vuosina esillä olleita näkökulmia. Keskeisenä yhteistyötahona kriteerien rakentamisessa on ollut englantilainen Birminghamin yliopiston emeritusprofessori John M. Hull, jonka näkemykset ja käsitykset uskonnon opetuksesta ovat vaikuttaneet olennaisesti kriteerien täsmentämiseen. Kriteerien rakentaminen on nähtävä pyrkimyksenä kehittää korkealla abstraktitasolla olevia periaatteita uskonnon opetuksen toteutukselle eri maissa. Vaikka kriteerit on luotu pääosin uskonnon opetusta varten, ne soveltuvat kaikkeen yleissivistävässä koulussa tapahtuvaan katsomusaineiden opetukseen. 
Kriteerien kehittämisen taustalla on useita syistä. Uskonnon opetuksen tutkijat ovat olleet selvästi tyytymättömiä Euroopan unionin tapaan rajata uskonto ja uskonnon opetus kansalaisten yksityisasiaksi. Luomalla kansainväliset kriteerit oppiainetta voidaan tarkastella yleisemmällä tasolla. Yhteisten kansainvälisten kriteerien rakentaminen osoittaa uskonnon opetuksella olevan yhteiskuntarajoja ylittävää merkitystä. Alan tutkijoita on hämmästyttänyt uskonnon opetuksen ja koulukasvatuksen eettisen ulottuvuuden rajaaminen OECD: $\mathrm{n}$ toteuttaman PISA-tutkimuksen ulkopuolelle.

Uskonnon opetuksen tutkijoiden tavoitteena on ollut yleisen tietoisuuden lisääminen oppiaineesta ja sen mahdollisuuksista sekä tehtävistä yhdentyvässä Euroopassa. Uskonnon opetus nähdään nykyisin Euroopassa yhä suuremmassa määrin koulun professionaalisena oppiaineena, joka on pääsemässä eroon aikaisemmasta katekeettisesta ja kirkollisesti orientoituneesta profiilistaan. Oppiaineen kansainvälisten kriteerien rakentaminen voidaan nähdä osana tätä kehitystä.

Schweitzerin (2002, 49-56) nimeämät viisi uskonnon opetuksen kansainvälistä kriteeriä ovat seuraavat:

1. uskontoa tulee opettaa yleisten kasvatusperiaatteiden mukaan,

2. uskonnon opetuksella on yhteiskunnallinen merkitys ja oppiainetta tulee opettaa tästä lähtökohdasta käsin,

3. uskonnon opetukseen tulee sisältyä uskontokuntarajoja rikkovaa ainesta,

4. uskonnon opetuksen tulee perustua lapsen oikeuteen uskontoon ja oikeuteen saada uskonnon opetusta ja

5. uskonnon opettajien tulee saavuttaa sellainen itse-reflektion taso, joka mahdollistaa kriittisen suhtautumisen omaan uskonnolliseen elämänkertaan.

Seuraavassa esitellään kriteeri kriteeriltä niitä keskeisiä näkökulmia, joita kriteereihin sisältyy. Ensinnäkin uskontoa tulee opettaa yleisten kasvatusperiaatteiden mukaan. Uskonnon opetus on osa yleistä koulukasvatusta ja kuuluu luonnollisena osana koulun yleiseen tehtävään yhteiskunnassa. Oppiaineen opetus on välttämätöntä, sillä uskonnot ovat osa sitä todellisuutta, jonka keskellä lapset ja nuoret kasvavat. Monipuolinen henkinen kasvu edellyttää elämän henkisen ja spirituaalisen ulottuvuuden tuntemista. Uskonnon opetus on perusteltua siihen sisältyvän etiikan opiskelun näkökulmasta. Yhteiskunta tarvitsee uskonnon opetusta ylläpitääkseen eettisiä periaatteitaan sekä opettaessaan sietokykyä uskonnollista erilaisuutta kohtaan.

Toiseksi uskonnon opetuksella on yhteiskunnallinen merkitys ja oppiainetta tulee opettaa tästä lähtökohdasta käsin. Useimmat eurooppalaiset uskonnon opetuksen asiantuntijat ovat yksimielisiä siitä, että uskonnon opetus ja demo- 
kratian toteuttaminen kuuluvat yhteen. Uskonto liittyy yhteiskunnan arvoihin ja eettisiin normeihin. Uskonnon opetuksen avulla yhteiskunta voi ylläpitää moraalista perustaansa. Oppiaineen opetus yleissivistävässä koulussa mahdollistaa sen, että kansalaiset tutustuvat yhteiskunnassaan vaikuttaviin arvoihin, eettisiin periaatteisiin ja normeihin.

Kolmanneksi uskonnon opetukseen tulee sisältyä uskontokuntarajoja rikkovaa ainesta. Monikulttuurisessa ja moniuskontoisessa yhteiskunnassa uskonnon opetus ei voi keskittyä vain yhden uskonnon opetukseen. Uskontojen välinen rauha ja erilaisen katsomusperinteen sietokyky sekä aktiivinen dialogi eri katsomusperinnettä edustavien ihmisten välillä kuuluvat keskeisimpiin poliitikkojen muotoilemiin tavoitteisiin kansallisella ja kansainvälisellä tasolla. Uskonnon opetuksen asiantuntijoiden keskuudessa on keskusteltu siitä, millä tavalla ja missä laajuudessa uskontokuntien rajoja rikkovaa ja uskontojen välistä ainesta tulisi uskonnon opetuksessa opettaa. Tästä alan tutkijat eivät ole yksimielisiä. Sen sijaan alan asiantuntijat ovat hyvin yksimielisiä siitä, että oppiaineella ei ole Euroopassa tulevaisuutta, jos siihen ei sisälly uskontokuntarajoja rikkovaa ja ylittävää ainesta. Uskonnon opetuksessa on käsiteltävä eri uskontoihin ja katsomuksiin liittyvää ainesta, koska se lisää oppiaineen yhteiskunnallista relevanssia. Jos yleissivistävässä koulutuksessa halutaan tulevaisuudessakin antaa uskonnon opetusta ja yleensäkin katsomuksiin liittyvää opetusta, sen tulee sisältää eri uskontoihin ja katsomuksiin liittyvää ainesta.

Neljänneksi uskonnon opetuksen tulee perustua siihen, että lapsella on oikeus uskontoon ja oikeus saada uskonnon opetusta. Tämä kriteeri palautuu uskonnon opetuksen tehtävään osana yhteiskunnan antamaa yleissivistävää opetusta. Kriteeri viittaa YK:n lasten oikeuksien julistukseen, jonka 27. artiklan mukaan lapsella on oikeus fyysiseen, henkiseen, spirituaaliseen, moraaliseen ja sosiaaliseen kehitykseen. Vaikka lasten oikeuksien julistuksessa ei ole suoraa viittausta uskonnon opetukseen, niin alan asiantuntijat ovat yksimielisiä siitä, että uskonnon opetuksella ja lasten oikeudella spirituaaliseen kehitykseen on yhteys. Lasten spirituaalisista oikeuksista ei voida puhua ainoastaan yleisellä abstraktitasolla, vaan spirituaalisilla oikeuksilla on luotava myös selviä kasvatuksellisia mahdollisuuksia. Uskonnon opetuksen tulee perustua lasten tarpeisiin ja kiinnostukseen ja sen tulee seurata lapsen yleistä kehitystä.

Viidenneksi uskonnon opettajan tulee saavuttaa sellainen itse-reflektion taso, joka mahdollistaa kriittisen suhtautumisen omaan uskonnolliseen ja katsomukselliseen elämänkertaan. Oppiaineen opettajilla ja sellaiseksi opiskelevilla tulee olla mahdollisuus kriittisesti reflektoida omaa uskonnollista ja katsomuksellista elämänkertaansa, jonka kautta heille kehittyy persoonallinen, professionaalinen asenne omaan uskontoon ja katsomukseen.

Kriteerien edustama käsitys uskonnon opetuksesta perustuu pitkälti kasvatukselliselle näkökulmalle. Oppiaineen opetuksen lähtökohtana on lapsen 
oikeus uskontoon. Opetuksella on yhteiskunnallinen merkitys ja sen sisältöihin tulee kuulua uskontokuntarajoja ylittävää ainesta. Näin kriteerit viittaavat brittiläisessä uskonnon didaktiikassa yleisesti esillä olleisiin lähestymistapoihin: 'oppia uskontoa' ja 'oppia uskonnosta'. Kriteerien edustama näkökulma sen sijaan poikkeaa olennaisesti lähestymistavasta 'oppia uskonto', jonka mukaan opetuksen tehtävänä on tietyn yksittäisen uskonnollisen tradition tarkastelu ja tavoitteena tehdä oppilaista kyseisen uskonnon kannattajia tai vahvistaa heidän sitoutumistaan siihen.

\section{Suomalainen katsomusaineiden opetus ja Schweitzerin esittämät kriteerit}

Schweitzerin (2002) esittämät kriteerit eivät ole olleet mitenkään itsestään selvyys vähemmistöuskontojen opetuksen kohdalla. Esimerkiksi joidenkin vähemmistöuskontojen opetussuunnitelmat eivät ole sisältäneet juuri lainkaan uskontokuntarajoja ylittävää aineista, vaan ovat pitäytyneet yksinomaan oman tradition tarkastelussa. (Pyysiäinen 2000.) Käytännön opetustyössä ei joidenkin vähemmistöuskontojen osalta ilmeisesti ole nähty juuri eroa uskonnollisen yhdyskunnan ja yhteiskunnan antaman opetuksen välillä. Vähemmistöuskontojen opettajien koulutukseen liittyvien puutteiden vuoksi Suomessa on joidenkin vähemmistöuskontojen opetuksen osalta se tilanne, ettei koko maassa ole yhtään muodollisesti pätevää uskonnon opettajaa. Jos uskonnon aineenopettaja ei ole suorittanut oppiaineeseen liittyvää korkeakoulututkintoa ja asianmukaista opettajankoulutusta, niin kyky oman uskonnollisuuden kriittiseen itse-reflektointiin voi jäädä olemattomaksi.

Nyt tarvitaan keskustelua kriteereiden kattavuudesta ja osuvuudesta. Esimerkiksi, kun kriteereitä tarkastellaan suomalaisesta tilanteesta käsin, nousee väistämättä kysymys, miksi tutustumista omaan uskonnolliseen traditioon ei ole nostettu nykyistä keskeisempään asemaan. Globalisoituvassa maailmassa omien kulttuuristen juurien tunteminen ja kasvu omaan alueelliseen identiteettiin on olennaista.

Lapsen yleinen oikeus saada uskonnon opetusta on sinänsä tärkeää, mutta toivottavaa olisi, että kriteereihin sisältyisi myös oikeus saada nimenomaan tietoa omasta uskonnosta, sen keskeisistä kertomuksista ja perinteistä hahmottaa elämää ja ihmisyyttä. Uskontokuntarajoja ylittävien sisältöjenkin tarkastelussa on olennaista tuntea oman uskonnon perinteet ja kertomukset. Sietokyvyn kasvattaminen erilaisuutta kohtaan on mahdollista vasta, kun oma traditio tunnetaan mahdollisimman syvällisellä tasolla. Aito dialogi eri uskontoja ja katsomuksia edustavien välillä ei liene mahdollista ilman syvällistä oman us- 
konnon ja katsomuksen tuntemista sekä sen keskeisten kertomusten, juhlapyhäperinteen ja muun käytännön sisäistämistä.

\section{Katsomusopetuksen kehittyvä laadukas toimintakulttuuri}

Katsomusaineiden opetuksessa tarvitaan oppiaineiden luonteesta johtuen omaa spesifiä toimintakulttuuria. Katsomusaineiden opetuksen keskeisimpänä tehtävänä voidaan pitää aineksien antamista oppilaille oman identiteetin ja maailmakuvan rakentamiseksi. Sosiokulttuurinen ja kokemuksellisen oppimisen teoreettinen viitekehys soveltuu hyvin katsomusopetuksen keskeiseksi paradigmaksi. Siinä oppiminen nähdään oppilaan koko persoonaa koskettavana kasvuna. Oppiminen on oppilaalle merkityksellistä, elämyksellistä ja omakohtaiseen kokemukseen pohjaavaa (vrt. Kohonen 2001; 2005). Katsomusaineiden opetuksen ongelmana on usein ollut, että opetus jää irralliseksi oppilaiden arkielämästä, eikä liity heidän kokemus- ja elämysmaailmaansa. Katsomusaineiden opetuksessa tulisi tietoisesti rakentaa sellaista toimintakulttuuria ja pedagogista viitekehystä, joka painottaa opetuksen merkityksellisyyttä ja liittää opetuksen oppilaiden kokemusmaailmaan.

Kohosen $(2001 ; 2003 ; 2005)$ mukaan keskeisiä piirteitä sosiokulttuurisen ja kokemuksellisen oppimisen teoriassa ovat seuraavat: 1. oppilaan omat päämäärät ja autonomia, 2. henkilökohtainen sitoutuminen oppimiseen, 3. omaehtoinen ja vastuullinen opiskelu, 4. oppimisen mielekkyys, syvyys ja laajaalaisuus, 5. itsearvioinnin korostuminen ja 6 . opetuksen oppilas- ja merkityskeskeisyys.

Katsomusaineiden opetuksen toimintakulttuurissa keskeisiä ovat oppilas, hänen elämäkysymyksensä ja monipuolinen henkinen kasvunsa. Oppilas nähdään katsomusaineiden opetuksessa autonomisena subjektina, itseohjautuvana persoonallisuutena, joka kykenee sosiaalisesti vastuulliseen yhteistyöhön.

Katsomusaineiden opetuksen toimintakulttuurin keskeisenä pedagogisena periaatteena on avata lapselle ja nuorelle toisaalta hänen oma uskonnollinen traditionsa, muun muassa siihen liittyvät kertomukset ja elämäntulkinnat, toisaalta taas keskeisenä periaatteena on valmiuksien antaminen elämään dialogissa erilaisten ihmisten kanssa moniuskontoisessa yhteiskunnassa. Tämän lisäksi keskeisenä lähtökohtana on eettisten valmiuksien antaminen persoonalliseen ja yhteisölliseen elämään. Nämä tavoitteet ja tehtävät ovat niin moninaiset, että niiden saavuttaminen ei ole mahdollista ilman sosiokulttuurisen ja kokemuksellisen oppimisen teorian syvällistä sovellutusta katsomusaineiden opetuksen toimintakulttuuriin. 


\section{Katsomusaineiden opettaja etiikka}

Opettajan ammattia on viimeaikoina didaktisessa kirjallisuudessa pidetty voimakkaasti eettisenä ammattina, johon liittyy korkea eettinen vastuu ja joka edellyttää hyvää koulutusta arvokysymysten tarkasteluun ja käsittelyyn (esim. Räsänen 1998, 32-33). Katsomusaineiden opettajalla on etiikkaan eräänlainen kaksoissidos: eettinen aines katsomusaineiden opettajan ammatissa on vahva jo oppiaineen olemuksen vuoksi: etiikka on osa katsomusaineiden opettajan tiedollista asiantuntijuutta. Sen merkitys korostuu vielä, kun tarkastellaan, miten laajasti ajatus opettajuudesta eettisenä ammattina on hyväksytty. Suomessa on julkaistu opettajan ammatilliset periaatteet ja Opetusalan eettinen neuvottelukunta on toiminut vuodesta 2000 lukien. Opettajan ammattietiikka voidaan määritellä asiantuntijuuden, tiedon ja eettisen vastuun vuorovaikutukseksi ja yhteydeksi. Ammattietiikka on haaste asiantuntijuuden ja oman alan syvempään ymmärtämiseen.

Professionaalisuus merkitsee katsomusaineiden opettajan ammatissa toisaalta ammattitaidon tuomaa vapautta, toisaalta taas vastuuta toimia ammatissa eettisesti korkeatasoisesti. Professionaalisuuteen kuuluu oman ammattitaidon kehittämiseen liittyviä haasteita, mutta myös lukuisia omaa persoonaa ja tunne-elämää koskettavia haasteita. Sitoutuminen ammatin päämääriin on yksi katsomusaineiden opettajien keskeisistä ammatillisista haasteista. Katsomusaineiden opettajan ammatin eettiseen luonteeseen liittyvät laaja professionaalinen vastuu ja professionaalinen palveluorientaatio. (Vrt. Kallioniemi 1998, 330-332.)

Katsomusaineiden opettajan ammatin kohdalla etiikan painottamisessa on kysymyksessä itsestään selvyys eikä pelkkä pyrkimys. Katsomusaineiden opetuksessa työskennellään kasvavien oppilaiden kanssa. Oppiaines sisältää elementtejä, jotka liittyvät oppilaiden kehittyvään identiteettiin ja sen muotoutumiseen. Valmiuksien antaminen oppilaille elämänpolitiikan rakentamiseen jälkiteollisessa yhteiskunnassa on eettisesti vaativa tehtävä. Katsomusaineiden opettajana toimiminen voidaan nähdä eettisiin kysymyksiin erikoistuneen ammattipohtijan tehtävänä, jonka keskeisiä ammatillisia taitoja ovat muun muassa eettinen sensitiivisyys, eettisten dilemmojen ratkaisutaidot sekä eettisen kasvatuksen ja arvokasvatuksen menetelmälliset taidot. (Kallioniemi 2005b, 432-433.)

Professionaalinen vastuu edellyttää eettisesti korkeatasoista toimintaa katsomusaineiden opettajan ammatissa. Opettajan on tärkeä tiedostaa tehtävänsä eettinen luonne. Katsomusaineiden opettaja joutuu usein pohtimaan oman etiikkansa lähtökohtia. Suomalaisen yhteiskunnan syvä murros on muuttanut yhteiskuntamme eettistä arvopohjaa. Katsomusaineiden opettajan moraalinen viitekehys on tänään täysin erilainen kuin muutamia vuosikymmeniä sitten. 
Kasvatuksen yksilöityminen ja individualisaatio ovat Launosen (2000) mukaan korostuneet 1990-luvun pedagogisten tekstien ydinsanomana. Koulukasvatuksen etiikan muutoksen taustalla ovat sekä koulutuspolitiikan että koulukasvatuksen liberalisoituminen ja moniarvoistuminen. Koulukasvatuksen peruslähtökohtana on nykyisin "yksilöllisen valinnan horisontti". Kun yhteiskunta ei enää koulukasvatuksessa siirrä yhtenäisiä arvoja, niin oppilaasta on tullut arvojen itsenäinen valitsija ja prosessoija. Opettajan rooli on muuttunut lähinnä oppimisympäristöjen suunnittelijaksi ja erilaisten arvokokemusten mahdollistajaksi. 1990-luvun pedagogisissa teksteissä koulun arvokäsitys ilmentää eettistä konstruktivismia ja osin myös eettistä subjektivismia. (Launonen 2000, 296-297.)

Värrin (2002) mukaan opettajan odotetaan nykyisin olevan samanaikaisesti tutkiva opettaja, kriittinen intellektuaali, moraalikasvattaja, syrjäytymisen ehkäisijä, mediakasvattaja ja uuden yhteiskunnan rakentaja sekä postmoderni ihminen samassa persoonassa. Kuvattu moraalinen viitekehys on konteksti, jossa katsomusaineiden opettajan tulisi rakentaa omaa professionaalista etiikkaansa. Keskeistä professionaalisen etiikan rakentamisessa on katsomusaineiden opettajan oman tietoisuuden reflektiivinen avaaminen ja eettisten kysymysten pohtiminen.

Professionaaliseen palveluorientaatioon kuuluvia katsomusaineiden opettajan eettisiä asenteita ovat muun muassa sitoutuminen eettiseen koodiin, inhimillisyyden kunnioittaminen, halu sitoutua kasvattamaan oppilasta kaikenpuoliseen hyvään. Opettajan ammattieetoksen keskeisiksi elementeiksi voidaan määritellä totuudellisuus, oikeudenmukaisuus ja huolenpito. Katsomusaineiden opettajan professionaalinen palveluorientaatio kiteytyy näihin.

\section{Katsomusaineiden opettaja kulttuurisena sivistystyöntekijänä}

Katsomusaineiden opettajan tehtävä jälkiteollisen yhteiskunnan koululaitoksessa määrittyy ammatin ydinosaamisen pohjalta. Keskeisinä ydinosaamisalueina ovat eri uskontojen ja katsomusten kulttuuriperinnön ja etiikan opetus. Kokoavana käsitteenä on kulttuurinen sivistystyö, jonka ytimessä ovat klassisen humanismin pohjalta nousevat sivistyksen ulottuvuudet: totuus, hyvyys ja kauneus. Niiden lisäksi kulttuurimme ydinarvoina ovat kristinuskon sisältämä lähimmäisenrakkaus ja uuden ajan tärkeä perusarvo, vapaus.

Nämä kytkeytyvät tiiviisti ihmisenä olemiseen ja ihmisen tehtävään maailmassa. Inhimillistä elämää ei voida ajatella ilman näiden perustekijöiden tuntemusta. Opetuksen ja kasvatuksen tehtävänä on niiden vahvistaminen ja monipuolinen rikastuttaminen. Ne luovat perustan yhteiskunnan elämälle, ar- 
voille ja yksilön identiteetille. Totuus, hyvyys, kauneus, lähimmäisenrakkaus ja vapaus ovat inhimillisiä ydinarvoja, jotka antavat suunnan ihmisen ja kulttuurin kehitykselle. Ne muodostavat perustan katsomusaineille koulun oppiaineina ja katsomusaineiden opettajan ammatille.

Katsomusaineiden opettajan tärkein työväline on persoonallisuus. Yhtenä opetuksen ja kasvatuksen perustehtävänä voidaan pitää inhimillisyyden herättämistä. Katsomusaineiden opetuksessa inhimillinen elämä on syvästi läsnä kaikissa eri muodoissaan. Opetuksen tehtävänä on syventää oppilaiden henkistä rikkautta. Taide-elämysten avaaminen, luonnon puhuttelevuus ja toisen ihmisen syvällinen kohtaaminen sekä ihmisten välisen vuorovaikutuksen eettinen analysointi ovat katsomusaineiden opetuksen keskeisiä mahdollisuuksia, joiden vaikutus oppilaan kasvulle ja kehitykselle voi olla aivan ainutlaatuinen.

Katsomusaineiden opettajan mahdollisuus kulttuurisena sivistystyöntekijänä on siinä, että hän välittää persoonallisuutensa kautta inhimillistä kiinnostusta ja hyväksyntää oppilaitaan kohtaan sekä avaa heille uskontojen, katsomusten, kulttuuriperinnön ja arvojen rikkaan sekä monisäikeisen maailman. Tämä on olennaisinta katsomusaineiden opettajan asiantuntijuudessa alati muuttuvassa ja murroksessa olevassa maailmassa ja yhteiskunnassa. Katsomusaineiden opetuksen laadun ydin on valmiuksien antaminen elämän henkisten kysymysten tarkasteluun. Tämä tarkastelu ei ole mahdollista ilman syvää eettistä ja moraalista koodistoa.

\section{Lähteet}

Heimbrock, H.-G., Scheilke, C. \& Schreiner, P. (2001). Towards Religious Competence. Diversity as a Challenge for Education in Europe. Schriften aus dem Comenius-Institut. Muster: Lit.

Hirsch, E. D. (1998). Cultural Literacy: What Every American Needs to Know. New York: Vintage Books.

Kallioniemi, A. (1995). Uskonnollinen ja katsomuksellinen yleissivistys uskonnon opetuksen tavoitteena. Teoksessa Tella, S. (toim.), Juuret ja arvot. Etnisyys ja eettisyys - aineen opettaminen monikultturaalisessa oppimisympäristössä. Helsingin yliopiston opettajankoulutuslaitos. Tutkimuksia 150, 107-120. Helsinki: Yliopistopaino.

Kallioniemi, A. (1998). Uskonnon opettajan ammatti tutkimuskohteena. Teologinen aikakauskirja 4/1998, 330-335.

Kallioniemi, A. (2000). Aikuislukion opiskelijoiden uskomukset uskonnon- ja historianopetuksesta. Helsingin yliopiston opettajankoulutuslaitos. Tutkimuksia 210. Helsinki: Hakapaino. 
Kallioniemi, A. (2005a). Varhaiskasvatuksen uskontokasvatus monikulttuuristuvassa maailmassa. Teoksessa Hilska, P., Kallioniemi, A. \& Luodeslampi, J. (toim.), Uskontokasvatus monikulttuurisessa maailmassa, 11-38. Helsinki: Kirjapaja.

Kallioniemi, A. (2005b). Muuttuva uskonnon aineenopettajuus. Teoksessa Kallioniemi, A. \& Luodeslampi, J. (toim.), Uskonnon opetus uudella vuosituhannella, 423-437. Helsinki: Kirjapaja.

Kansanen, P. (1996). Kasvatuksen eettinen luonne. Teoksessa Pitkänen, P. (toim.), Kasvatuksen etiikka, 13-19. Helsinki: Edita.

Kohonen, V. (2001). Towards experiental foreign language education. In Kohonen, V., Jaatinen, R., Kaikkonen, P. \& Lehtovaara, J., Experiental Learning in Foreign Language Education, 8-60. London: Pearson Education.

Kohonen, V. (2002). Yhteistoiminnallisuus oppimiskulttuurin muutoksessa. Teoksessa Sahlberg, P. \& Sharan, S. (toim.), Yhteistoiminnallisen oppimisen käsikirja, 348-366. Helsinki: WSOY.

Kohonen, V. (2005). Aineenopettajakoulutuksen kehittämisen mahdollisuuksia. Teoksessa Jakku-Sihvonen, R. (toim.), Uudenlaisia maistereita. Kasvatusalan koulutuksen kehittämislinjoja. PS-Kustannus. Opetus 2000, 277-298. Keuruu: Otava.

Launonen, L. (2000). Eettinen kasvatusajattelu suomalaisen koulun pedagogisissa teksteissä 1860-luvulta 1990-luvulle. Jyväskylä Studies in Education: Psychology and Social Research 168. Jyväskylä: Jyväskylän yliopisto.

Perusopetuksen opetussuunnitelman perusteet (2004). Helsinki: Opetushallitus.

Pyysiäinen, M. (2000). Yksi oppiaine, seitsemän opetussuunnitelmaa. Peruskoulun ja lukion opetushallituksen 1990-luvulla vahvistamien opetussuunnitelmien tunnustuksellinen luonne. Tutkimuksia 223. Helsinki: Helsingin yliopiston opettajankoulutuslaitos.

Rusama, J. (2002). Uskonto, elämänkatsomustieto ja tapakasvatus. Oppimistulosten arviointi perusopetuksen päättövaiheessa 2001. Oppimistulosten arviointi 5/2002. Helsinki: Opetushallitus.

Räsänen, R. (1998). Opettajankoulutuksen eettiset haasteet. Teoksessa Puheenvuoroja opettajan etiikasta. OAJ, 31-41. Helsinki: Sävypaino.

Scweitzer, F. (2002). International Standards for Religious Education-In Converstation with John M. Hull. Panorama Vol. 14 (1), 49-56.

Smith, B. H. (1992). Cult-Lit: Hirsch, Literacy and the "National Culture". In Gless, D. J. \& Smith, B. H. (eds.), The Politics of Liberal Culture, 75-94. Durkham: Duke University Press.

Välijärvi, J. (1993). Kurssimuotoisuus opetussuunnitelman moduulirakenteen sovellutuksena lukiossa. Diss. Kasvatustieteen tutkimuslaitoksen julkaisusarja A 54. Jyväskylän yliopisto. Jyväskylä: Jyväskylän yliopiston monistuskeskus.

Värri. V.-M. (2002). Opettaja tässä ajassa - viis teesiä opettajan etiikasta. Teoksessa Etiikka koulun arjessa. Opetusalan Ammattijärjestö OAJ ja Kustannusyhtiö Otava, 55-63. Keuruu: Otava. 
II

Uskonnon opetus 



\title{
Näkökulmia eurooppalaiseen uskonnon opetukseen - oppiaineen kehittämisen haasteita Norjassa ja Suomessa
}

\author{
Arto Kallioniemi
}

Tiivistelmä

Artikkelissa tarkastellaan ensiksi uskonnon opetusta ja sen toteutusta Euroopassa. Tämän jälkeen esitellään erilaisia eurooppalaisia uskonnon opetuksen toteutusvaihtoehtoja. Seuraavaksi artikkelissa esitellään UNESCO:n tekemää kartoitusta uskonnon opetukseen käytetystä ajasta eri maissa. Artikkelissa kuvataan Plesnerin luomaa mallia uskonnon opetuksen tarkastelemiseksi kahden perusulottuvuuden oppiaineen profiilin ja vastuun näkökulmasta. Oppiaineen profililla tarkoitetaan uskonnon opetuksen luonnehtimista ulottuvuudella tunnustukseton-tunnustuksellinen ja tyypitellään tämän pohjalta eri maiden uskonnon opetusmalleja segregaatiota lisä̈̈viksi tai integroiviksi. Toisella perusulottuvuudella vastuu tarkastellaan sitä, kenellä on vastuu uskonnon opetuksen suunnittelusta ja toteutuksesta: kouluilla vai uskonnollisilla yhteisöillä. Artikkelissa esitellään Euroopan neuvoston vuonna 1999 antamaa suositusta uskonnosta ja demokratiasta, jossa esitetään, että jäsenvaltiota edistäisivät opetusta uskonnoista. Tämän jälkeen tarkastellaan Kodeljan ja Basslerin (2004) esittämiä käsityksiä uskonnon opetuksesta Euroopan neuvoston suositusten pohjalta. Artikkelissa esitellään suomalaista uskonnon opetusjärjestelmää ja pohditaan sen kehittämisvisioita. Eräänlaisena referenssimaana esitellään Norjaa ja siellä tapahtunutta uskonnon opetuksen kehittymistä 1990-luvulla. Lopuksi pohditaan uskonnon opetuksen uudistamista Suomessa erityisesti oppiaineen kontekstin näkökulmasta.

Avainsanat: uskonnon opetus, uskonnon opetusmalli, suomalainen uskonnon opetus, norjalainen uskonnon opetus, perusasteen uskonnon opetuksen kehittäminen

\section{Uskonnon opetus Euroopan maissa}

Viimeaikainen Euroopassa tapahtunut uskonnon opetuksen kehittäminen ja alan ainedidaktinen tutkimus on olennaisesti tapahtunut kontekstuaalisen lähestymistavan viitekehyksessä. Kontekstuaalisessa lähestymistavassa tarkastellaan kasvatuksen tavoitteita ja kysymyksiä tietyssä sosiaalisessa ja kult- 
tuurisessa viitekehyksessä. Keskeisenä näkökulmana on pohtia, miten kasvatuksen tavoitteet ja tehtävät sekä sosiaalinen ja kulttuurinen viitekehys ovat aktiivisessa vuorovaikutuksessa keskenään. Kontekstuaalisuuden käsitteellä viitataan myös siihen interaktiiviseen vuorovaikutukseen, joka on oppilaiden ja vallitsevan sosiaalisen ja kulttuurisen tilanteen välillä. (Hull 2002, 123-125; Heimbrock 2004, 90-91.)

Uskonnon opetus tapahtuu useimmissa Euroopan maissa yleisten koulujen kontekstissa pluralisoituneessa, moniuskontoisessa yhteiskunnassa. Keskeisimpiä uskonnon opetuksen haasteita Euroopassa on käsitellä ja opettaa uskonnon opetuksessa konstruktiivisesti kulttuurista ja uskonnollista moninaisuutta. Uskonnon opetuksen odotetaan auttavan kehittämään kansalaisissa monipuolista erilaisuuden ymmärtämistä ja sietokykyä. Eri maiden uskonnon opetusmallien tarkastelu, tuntemus ja vuorovaikutus ovat tärkeitä kunkin maan oman uskonnon opetusmallin kehittämisen kannalta. Pluralistiseen yhteiskuntaan soveltuvasta uskonnon opetuksen muodosta ja yleensäkin koulussa annettavasta arvokasvatuksesta sekä niiden liittymisestä ihmisoikeuksiin ja uskonnonvapauteen keskustellaan aktiivisesti eri puolilla Eurooppaa. (Esim. Plesner 2002, 111.)

Uskonnon opetuksen tarkastelu eurooppalaisella tasolla ei ole yksinkertainen tehtävä, sillä uskonnon opetuksen asema, muoto ja toteutus ovat erilaisia eri maissa. Hullin (2001) mukaan voidaan erottaa yleisiä tekijöitä, jotka vaikuttavat uskonnon opetuksen lähestymistapaan eri maissa. Näitä ovat muun muassa seuraavat: 1. yhteiskunnan uskonnollinen ilmapiiri, 2. uskonnon ja maallisen suhde kussakin maassa ja 3. eri maiden historiallinen traditio sekä 4 . käsitykset uskonnon opetuksen tehtävästä ja olemuksesta yhteiskunnan koulujärjestelmässä (Hull 2001, 1-2).

Esimerkiksi katolisissa maissa (Italiassa, Espanjassa, Portugalissa ja Puolassa) katolisuuden vaikutus ja merkitys kulttuurissa ja koulutuksessa on syvä. Maissa, joissa on sekoittunut uskonnollinen ilmapiiri, kuten esimerkiksi Alankomaissa, uskonnollisten yhteisöjen (esimerkiksi katolisen kirkon ja reformoidun kirkon) vaikutus yhteiskunnan kasvatusjärjestelmän eriytymiseen on ollut historiallisesti merkittävä. Kiintoisan näkökulman erilaisesta yhteiskunnasta tarjoaa myös Ranska, jossa uskonnolla ja uskonnon opetuksella ei ole asemaa yleisissä kouluissa. Kuitenkin Ranskassa on lukuisia yksityiskouluja. Esimerkiksi $20 \%$ ranskalaisista oppilaista käy katolisen kirkon ylläpitämissä yksityiskouluissa, joissa uskonnon asema on vahva. (Schreiner 2002, 95.)

Uskonnon opetus ja sen järjestäminen on monimuotoinen poliittinen kysymys. Esimerkiksi uskonnon opetuksen järjestämiseen liittyy usein keskustelua kansainvälisten sopimusten erityisesti ihmisoikeuksiin, uskonnonvapauteen ja vähemmistösuojiin liittyvien sopimusten tulkinnasta, yhteiskunnan roolista 
sekä koulutusjärjestelmän rakenteesta, erityisesti ulottuvuudella yksityisenjulkinen (ks. esim. Kodelja \& Bassler 2004; Skeie 2006, 19-21).

Skeien (2001) mukaan uskonnon opetukseen liittyy poliittisia näkökulmia ainakin kolmella tavalla. Ensinnäkin uskonnon opetus osana koulutusjärjestelmää ja uskonnon opetuksen opetussuunnitelmat ovat useissa maissa erilaisten poliittisten järjestelmien tekemien päätösten tuloksia. Poliittisissa päätöksentekoprosesseissa ovat mukana puolueet, asiaan liittyvät intressiryhmät sekä uskonnolliset yhdyskunnat. Toiseksi Skeie nimeää tilanteet, joissa uskonnon opetuksen teoriaan tai käytäntöön liittyvät aiheet nousevat yleisen poliittisen keskustelun keskiöön. Kolmanneksi Skeie osoittaa, miten uskonnon opetus on yhteydessä esimerkiksi tapaan ymmärtää kansalaisuus, kansalaisoikeudet, vähemmistöjen integraatio yhteiskuntaan sekä monikulttuurisuuden kysymykset ja kasvatuksen laaja-alaiset tavoitteet. (Skeie 2001, 237, ks. myös Räsänen 2006, 11.)

Kun tarkastellaan uskonnon opetusta eri Euroopan maissa, on muistettava muun muassa seuraavat tarkasteluun liittyvät vaikeudet. Näitä ovat esimerkiksi terminologiset vaikeudet, kieleen ja kulttuurien välisiin eroihin liittyvät vaikeudet sekä koulutusjärjestelmän eroihin liittyvät vaikeudet. Uskonnon opetus käsitteenä on erilainen eri Euroopan maissa, vaikka tarkastelunäkökulmaksi rajattaisiin uskonnoksi nimitetty koulun oppiaine, joka sisältyy koulun yleiseen opetussuunnitelmaan. Eri maissa käytetyt luonnehdinnat esimerkiksi uskonnon opetuksen tunnustuksellisuudesta ovat kulttuurisidonnaisia: eri kulttuureissa tunnustukselliseen uskonnon opetukseen voidaan liittää hyvinkin erilaisia käsityksiä. Suuressa osassa Eurooppaa on merkittävä yksityiskoulujen järjestelmä. Pohjoismaissa sen sijaan on selvästi vähemmän yksityiskouluja kuin muissa Euroopan maissa: esimerkiksi Tanskassa oppilaista $12 \%$ on yksityiskouluissa ja Norjassa vain $2 \%$ (ks. esim. Hagesather \& Sandsmark 2006, 277; Skeie 2006, 20).

Uskonnollisten yhdyskuntien ylläpitämien koulujen määrä vaihtelee eri puolella Eurooppaa. Yhden näkökulman uskonnollisten koulujen asemaan avaa Alankomaiden tilanne, jossa 2/3 kouluista toimii kristilliseltä pohjalta ja vain 1/3 kouluista on uskonnollisesti neutraaleja. (Schreiner 2002, 96; 1999, 113-114.)

Uskonnon opetuksen asemaa eri eurooppalaisissa yhteiskunnissa ei ole helppo kuvata tyhjentävästi. Erään näkökulman uskonnon opetuksen asemaan tarjoaa UNESCOn $(2003,214)$ tekemä kartoitus, jossa tarkasteltiin 142 maata. Uskontoa opetettiin niissä noin puolessa eli yhteensä 73 maassa vähintään kerran oppilaiden yhdeksän ensimmäisen kouluvuoden aikana. Aikaa uskonnon opetukseen käytettiin 54 maassa keskimäärin 388,4 tuntia, mikä on 8.1 \% koulun kokonaisopetusajasta. Euroopan maissa uskonnon opetukseen käytettävä aika vaihteli suurestikin (ks. taulukko 1). Selvästi eniten uskonnon opetukseen 
käytettiin aikaa kuuden ensimmäisen kouluvuoden aikana Puolassa ja vähiten Slovakiassa.

Taulukko 1. Uskonnon opetukseen käytetty aika tunteina ja prosenttiosuutena kuuden ensimmäisen kouluvuoden aikana.

\begin{tabular}{l|c|c}
\hline Maa & Kokonaistuntimäärä & $\begin{array}{c}\text { Prosenttiosuus kou- } \\
\text { lun opetusajasta }\end{array}$ \\
\hline Puola & 456 & 10,3 \\
\hline Norja & 332 & 8,7 \\
\hline Itävalta & 380 & 8,2 \\
\hline Belgia (ranskankielinen osa) & 360 & 6,9 \\
\hline Suomi & 338 & 6,1 \\
\hline Tanska & 240 & 5,6 \\
\hline Englanti & 243 & 5,0 \\
\hline Islanti & 209 & 5,0 \\
\hline Kreikka & 210 & 4,8 \\
\hline Romania & 170 & 4,3 \\
\hline Liettua & 143 & 3,8 \\
\hline Turkki & 144 & 3,3 \\
\hline Slovakia & 59 & 1,4 \\
\hline
\end{tabular}

UNESCOn tekemään kartoitukseen on syytä suhtautua hieman kriittisesti, sillä eri maissa on erilainen lähtökohta kirjoittaa opetussuunnitelmia ja määrätä koulussa annettavien oppiaineiden opetukseen käytettyä aikaa. Esimerkiksi Suomessa valtioneuvosto vahvistaa eri aineiden opetukseen koulussa käytettävän ajan. Ruotsissa taas opetussuunnitelma on integroitu ja paikalliset koulut voivat melko itsenäisesti päättää eri tiedonalojen ja oppiaineiden määrällisistä painotuksista. Uskonnolle ei ole määrätty yksityiskohtaista tuntimäärää, vaan opetus on sisältynyt yhteiskuntaorientoituneiden oppiaineiden kokonaismäärään, joka 1990-luvulla oli 833 tuntia vuosiluokilla 1-9. (Orlenius 1995, 36; Olivestam 2006, 16-17; Valtioneuvosto 2001.)

Vaikka uskontoa ei kaikissa maissa opeteta erillisenä kouluaineena, niin eri oppiaineiden opetukseen voi liittyä uskontoon liittyviä sisältöjä. Niitä voidaan tarkastella esimerkiksi historian, maantieteen ja kulttuurikasvatuksen yhteydessä. (Kodelja 2004.) Kodeljan ja Basslerin (2004) mukaan uskonnon opetukseen käytetty aika eri puolilla maailmaa on selvästi kasvanut viimeisen vuosikymmenen aikana.

Uskonnon opetuksen kokoava tarkastelu eurooppalaisella tasolla ei ole helppo tehtävä. Alan tutkijat (Schreiner 1999; 2002, Skeie 2001; Plesner 2001; 2002) ovat luoneet erilaisista lähestymistavoista luokitteluja eurooppalaisten uskonnon opetusmallien systematisoimiseksi. Schreiner $(2002,263)$ on ot- 
tanut luokittelunsa lähtökohdaksi sen tarkastelun, kenelle kuuluu vastuu oppiaineen suunnittelusta ja toteutuksesta (ks. esim. Kallioniemi 2003a, 370). Skeien $(2001,242-243)$ luokittelun lähtökohtana on taas erottelu siitä, miten uskonnon opetuksen ja yleensä koulutuksen suhde on rakennettu. Skeien luokittelussa Euroopan maat on jaettu kahteen päätyyppiin. Ensimmäistä päätyyppiä voidaan nimittää yhdenmukaiseksi, vahvaksi ratkaisuksi. Siinä painottuu yhteiskunnan halu löytää yksi uskonnon opetusmalli, joka voi olla esimerkiksi tunnustuksellinen tai tunnustukseton uskonnon opetus. Toista päätyyppiä voidaan nimittää monimuotoiseksi tai heikoksi ratkaisuksi. Siinä taas korostuu yhteiskunnan vähäisempi halu luoda yhtenäinen malli uskonnon opetukselle. (Skeie 2001, 242-243; ks. myös Kallioniemi 2005a, 23-24.)

Plesnerin $(2001 ; 2002,111-114)$ esittelemässä luokittelussa on lähtökohtana tarkastella eri maissa toteutettuja uskonnon opetusmalleja seuraavien perusulottuvuuksien avulla: 1. uskonnon opetuksen profili ja 2. vastuu uskonnon opetuksesta. Seuraavassa keskitytään yksityiskohtaisemmin Plesnerin esittelemään luokitteluun. Siinä yhdistetään hieman monipuolisemmin useita uskonnon opetusmalliin liittyviä tekijöitä kuin Skeien (2001) ja Schreinerin (1999; 2002) esittämissä luokitteluissa.

Plesner on nimennyt ensimmäisen uskonnon opetusmallin perusulottuvuuden uskonnon opetuksen profiiliksi. Plesnerin (2002, 111-114) tutkimus osoittaa, että on mahdollista erottaa toisistaan tunnustuksellinen uskonnon opetus ja tunnustukseton uskonnon opetus. Tunnustuksellinen uskonnon opetus tähtää useimmiten oppilaan uskonnollisen identiteetin kehittämiseen ja vahvistamiseen. Tunnustuksellisen uskonnon opetuksen näkökulmana on perinteisesti ollut opetus, jonka tavoitteena on oppilaiden sitouttaminen yhteen uskonnon muotoon tai uskonnolliseen traditioon. Uskonnon opettaja on kyseinen uskonnon edustaja. Tunnustukselliselle opetukselle on ominaista, että uskonnon edustajat kontrolloivat uskonnon opetuksen opetussuunnitelmaa, oppimateriaaleja ja menetelmiä. (Hobson \& Edwards 1999, 17; Hull 2002, 3.)

Useissa maissa, joissa koulun uskonnon opetus on luonteeltaan tunnustuksellista, oppilailla on mahdollisuus valita koulun eri uskonnon opetuksen muodoista se, johon he osallistuvat. Uskonnon opetuksen sijaan he voivat useissa maissa osallistua esimerkiksi filosofian tai etiikan opetukseen. Esimerkiksi eräissä Saksan osavaltioissa oppilaiden vanhemmat voivat valita, että oppilaat osallistuvat tunnustuksellisen uskonnon opetuksen sijaan vaihtoehtoisen tai korvaavan oppiaineen opetukseen. Tämän oppiaineen nimi vaihtelee eri liittovaltioissa: aineen nimi voi olla esimerkiksi käytännöllinen filosofia, etiikka, arvot ja normit. (Schreiner 1999, 97; Davie 2000, 90-91; Kodelja 2004.)

Pluralistisessa yhteiskunnassa tunnustuksellinen uskonnon opetus vahvistaa Plesnerin (2002) mukaan uskontojen segregaatiota, jos koulussa opetetaan eri uskontoja. Tunnustukseton uskonnon opetus taas Plesnerin mukaan integ- 
roi eri uskontokuntiin kuuluvia oppilaita samaan uskonnon opetuksen muotoon. (Plesner 2002, 112.)

Toinen uskonnon opetusmallin perusulottuvuus tarkastelee uskonnon opetusta vastuun näkökulmasta. Keskeistä on tällöin tarkastella, kenellä on vastuu uskonnon opetuksen suunnittelusta ja toteutuksesta: kouluilla vai uskonnollisilla yhteisöillä ja yhdyskunnilla. Useimmissa maissa, joissa uskonnon opetus on tunnustuksetonta julkisissa kouluissa, kouluviranomaisilla on päätösvalta uskonnon opetuksen opetussuunnitelmasta ja oppiaineen opetuksessa käytettävistä materiaaleista. Tämänkaltainen menettelytapa on käytössä esimeriksi Ruotsissa, Norjassa ja Tanskassa. Poikkeuksena on Englanti, jossa uskonnon opetus on luonteeltaan tunnustuksetonta, mutta kouluviranomaiset ja uskonnolliset yhteisöt yhdessä kehittävät paikallistasojen uskonnon opetussuunnitelmia. (Plesner 2002, 112.)

Useimmissa maissa, joissa uskonnon opetus on tunnustuksellista, opetussuunnitelman kehittäminen ja opettajien palkkaaminen tapahtuvat yhteistyössä uskonnollisten yhdyskuntien kanssa, esimerkiksi Itävallassa, Italiassa ja useimmissa Saksan osavaltioissa. Valtion kouluviranomaiset päättävät Suomessa ja Kreikassa uskonnon opetuksesta, joka on periaatteessa pakollista ja tunnustuksellista. Joissakin Itä-Euroopan maissa, kuten esimerkiksi Unkarissa ja Brandenburgissa, tunnustuksellista uskonnon opetusta tarjotaan kouluissa, jos oppilaat sitä toivovat. Tällöin uskonnollisilla yhdyskunnilla on pääasiallinen vastuu opetussuunnitelmista. (Plesner 2002, 112.)

Tarkastelu-ulottuvuuksien pohjalta on koottu taulukko 2, jossa on kuvattu uskonnon opetuksen profiilia ja uskonnon opetuksen vastuuta joissakin esimerkkimaissa.

Taulukko 2. Uskonnon opetuksen profiili ja vastuu oppiaineen opetuksesta ristiintaulukoituina

\begin{tabular}{|c|c|c|}
\hline \multirow{2}{*}{$\begin{array}{l}\text { Vastuu uskon- } \\
\text { nonopetuksesta }\end{array}$} & \multicolumn{2}{|c|}{ Uskonnonopetuksen profiili } \\
\hline & Tunnustuksellinen (segregaatiomalli) & Tunnustukseton (integroitu) \\
\hline Koulu & $\begin{array}{l}\text { Suomi } \\
\text { Kreikka }\end{array}$ & $\begin{array}{l}\text { Ruotsi } \\
\text { Norja } \\
\text { Tanska }\end{array}$ \\
\hline $\begin{array}{l}\text { Koulu ja uskon- } \\
\text { nolliset yhteisöt }\end{array}$ & $\begin{array}{l}\text { Saksa } \\
\text { Italia } \\
\text { Itävalta }\end{array}$ & $\begin{array}{l}\text { Englanti } \\
\text { (Bremer-Hampuri) }\end{array}$ \\
\hline Uskonnolliset yhteisöt & Unkari (opetus koulussa) & \\
\hline Uskonnolliset yhteisöt & Ranska (opetus koulun ulkopuolella) & \\
\hline
\end{tabular}

Vaikka Plesnerin luoma malli ei anna täsmällistä kuvaa eri puolilla Eurooppaa toteutetuista uskonnon opetusmalleista, se tarjoaa näkökulman erilaisiin uskonnon opetuksen lähestymistapoihin ja malleihin. Malliin sisältyy myös 
heikkouksia. Esimerkiksi uskonnon opetuksen tarkastelu tunnustuksellinentunnustukseton -ulottuvuudella ei kuvaa kovinkaan monipuolisesti uskonnon opetuksen tavoitteita eikä sisältöjä. Tunnustukseton-tunnustuksellinen -käsitteiden käyttöön liittyy keskeisiä terminologisia vaikeuksia. Eri yhteiskunnissa näitä käsitteitä käytetään eri tavalla. Ne eivät kuvaa tyhjentävästi uskonnon opetuksen tavoitteita eivätkä sisältöä. Esimerkiksi Tanskassa ja Norjassa uskonnon opetus on luonteeltaan tunnustuksetonta. Näiden maiden uskonnon opetuksen tavoitteet ja sisällöt rakentuvat kuitenkin selvästi voimakkaammin luterilaisen tradition pohjalle kuin esimerkiksi suomalaisen luterilaisen uskonnon opetuksen. Vaikka suomalainen uskonnon opetus on oman uskonnon opetusta, se luokitellaan kansainvälisessä tarkastelussa lähes aina tunnustukselliseksi uskonnon opetukseksi. (Vrt. Kallioniemi 2006a, 75-85.)

\section{Euroopan neuvosto ja uskonnon opetus}

Euroopan neuvosto on vuonna 1999 antanut suosituksen uskonnosta ja demokratiasta. Asiakirjassa todetaan, että kasvatus on avaintapa välttää tietämättömyyttä ja stereotypioita. Koulujen ja yliopistojen opetussuunnitelmat tulisi uudistaa tavalla, joka edistää uskontojen välistä ymmärrystä. Uskonnon opetus on nähtävä osaksi historian, kulttuurin ja ihmiskunnan filosofisten kysymysten opetusta. Euroopan neuvosto suosittaa, että jäsenvaltiot edistäisivät opetusta uskonnoista erityisesti seuraavasti:

a. toteuttamalla uskontoihin ja arvoihin liittyvää opetusta tavalla, jonka avulla nuoret voivat kehittää arvostelukykyisen lähestymistavan eettisen kasvatuksen ja demokraattisen kansalaisuuden viitekehyksessä,

b. edistämällä kouluissa vertailevaa uskontojen tutkimusta painottamalla eri uskontojen juuria, uskontojen yhteisiä arvoja ja niiden erilaisia tapoja, traditioita ja juhlia,

c. rohkaisemalla uskontojen historian ja filosofian tutkimusta yliopistoissa rinnakkaisina teologiselle tutkimukselle,

d. tekemällä yhteistyötä uskonnollisten kasvatusinstituutioiden kanssa tavoitteena esitellä niiden opetussuunnitelmia ja

e. välttämällä yhteiskunnan ylläpitämässä kasvatuksessa uskontoon ja perheiden uskonnollisiin tapoihin liittyviä konflikteja ja kunnioittamalla perheiden vapaata valinnanmahdollisuutta hienotunteisella tavalla. (Council of Europe 1999, 10.)

Kodeljan ja Basslerin (2004) mukaan suositukset tarjoavat poliitikoille viitekehyksen, jossa kysymystä uskontoihin liittyvästä opetuksesta voidaan tarkas- 
tella. Yleisissä kouluissa annettavasta uskonnon opetuksesta voidaan heidän mukaansa esittää seuraavia argumentteja:

1. Ilman asianmukaista ja objektiivista tietoa eri uskonnoista lapset ja nuoret eivät voi ymmärtää useita historiaan, kulttuuriin ja yhteiskuntaan liittyviä kysymyksiä eivätkä uskontojen merkitystä ihmiskunnalla. Tältä pohjalta Kodelja ja Bassler (2004) yhtyvät Woodin (1984, 36) esittämään ajatukseen siitä, että yksilön kasvatus ei ole täydellistä ilman uskontojen opiskelua ja niiden näkemistä osana ihmiskunnan saavutuksia.

2. Uskontojen opetus tarjoaa tärkeää informaatiota lapsille ja nuorille. Se auttaa heitä sekä ymmärtämään nykypäivän yhteiskunnan pluralistista, monikulttuurista ja moniuskontoista yhteiskuntaan että elämään yhdessä erilaisten ihmisten kanssa.

3. Uskontojen opiskelu mahdollistaa lapsille ja nuorille paremman ymmärryksen muiden uskonnoista, kulttuuritraditioista, tavoista, arvoista ja elämänfilosofioista sekä auttaa oppilaita kehittämään ymmärrystä, sietokykyä ja arvostusta erilaisia ihmisiä kohtaan.

4. Uskontojen opiskelu rohkaisee oppilaita heidän omassa persoonallisessa kasvussaan ja saattaa auttaa heitä hankkimaan mahdollisuuksia tarkastella vaihtoehtoisia elämäntapoja ja antaa heille valinnan vapautta tässä mielessä.

5. Niissä sekulaareissa yhteiskunnissa, joissa uskonnon opetus on kielletty kouluissa, tunnustukseton uskonnon opetus on yksi ja kenties ainoa tapa varmistaa, että koulu kehittää oppilaiden uskonnollista yleissivistystä.

6. Niissä valtioissa, joissa opetetaan tunnustuksellista uskonnon opetusta yleisissä kouluissa, muihin uskontoihin liittyvää opetusta tulee antaa vaihtoehtoisena oppiaineena.

Kodeljan ja Basslerin (2004) näkemykset perustuvat pitkälti niihin näkökulmiin, jotka ovat olleen viimeaikaisen kansainvälisen uskonnon didaktisen tutkimuksen keskiössä (esim. Jackson 2003). Uskonnon opetus nähdään nykyisin selkeästi koulun oppiaineena ja koulun yhteiskunnallisena tehtävänä, jolla on laajat liittymäkohdat kansalaiskasvatukseen. Uskonnon opetus voi luoda muun muassa oppilaille mahdollisuuden ymmärtää velvollisuuden ja vastuun käsitettä sekä kehittää positiivista suhdetta ja ystävyyttä toisiin ihmisiin. Oppiaine tarjoaa myös mahdollisuuden tarkastella erilaisten yhteiskunnallisten konfliktien taustoja ja merkitystä. Uskonnon opetuksen avulla lasten ja nuorten itsetietoisuus voi laajentua yhteiskunnallisissa kysymyksissä. Oppiaine tarjoaa mahdollisuuden tutkia ja ymmärtää erilaisten arvojen merkitystä yhteiskunnassa ja kulttuurissa sekä kehittää lasten ja nuorten mahdollisuutta yhteiskun- 
nan jäsenyyteen aktiivisina, vastuuntuntoisina kansalaisina. (Arthur \& Wright 2001, 29.) Uskonnon opetus mahdollistaa myös lasten ja nuorten oman elämys- ja kokemusmaailman syvällisen reflektoinnin. Oppiaineen opetuksen tavoitteena on tukea lapsen ja nuoren kasvua etsimällä opetukseen ainesta, jolla on merkitystä heidän moraaliselle, henkiselle ja hengelliselle kehitykselleen. Näin uskonnosta oppiminen mahdollistaa persoonallisen kasvun ja kehittymisen kohti itsenäistä autonomiaa. (Hull 2001, 3-5.)

Viimeaikaisessa eurooppalaisessa keskustelussa (esim. Heimbrock \& al. 2001) on painotettu, että uskonnon opetuksen yleistavoitteena on uskonnollisen kompetenssin saavuttaminen. Käsitteen käyttäminen perustuu myös Kodeljan ja Basslerin (2004) esille tuomaan näkemykseen, että uskontoon liittyvä opetus ja oppiminen kuuluvat ihmisen kokonaisvaltaiseen kasvuun ja kehittymiseen. Uskonnollisella kompetenssilla voidaan tarkoittaa ihmisen kykyä käsitellä omaa uskonnollisuuttaan ja sen erilaisia ulottuvuuksia dynaamisella tavalla. Käsitteeseen liittyy myös ihmisen kyky ja valmius arvostaa toisten erilaisia uskonnollisia käsityksiä ja katsomuksia. Uskonnollinen kompetenssi käsittää aktiivisen kyvyn toleranssiin uskonnollista erilaisuutta kohtaan sekä kyvyn toimia erilaisissa konfliktitilanteissa eettisesti orientoituneella tavalla. Siihen kuuluu myös valmius dialogiin uskonnollisissa ja katsomuksellisissa kysymyksissä. Uskonnolliseen kompetenssiin sisältyy kyky käsitellä uskonnollista pluralismia ja eroja konstruktiivisella tavalla. (Heimbrock \& al. 2001, 9; Kallioniemi 2003b, 95.)

\section{Suomalainen uskonnon opetusjärjestelmä ja sen kehittäminen}

Suomalaista uskonnon opetusjärjestelmää luonnehdittiin vuoteen 2003 asti tunnustukselliseksi uskonnon opetukseksi. Ensimmäisen kerran käsitettä tunnustuksellinen uskonnon opetus käytettiin koululainsäädännössä ilmaistusta opetuksen organisointiperiaatteesta vuoden 1923 kansakoululaissa (Laki 18.5.1923/137 3 §), jonka mukaan opetuksen järjestäjän tuli antaa uskonnon opetusta enemmistön tunnustuksen mukaisesti. 1920-luvulla Suomessa enemmistönä olivat käytännössä evankelisluterilaiset oppilaat ja joissakin Itä-Suomen kouluissa ortodoksiset oppilaat. (Pyysiäinen 1998, 44; 2000, 1.)

Vaikka uskonnon opetuksen luonteesta, asemasta ja tehtävästä keskusteltiin suomalaisessa yhteiskunnassa laajasti 2000-luvun alussa uuden uskonnonvapauslain valmistelun yhteydessä, niin 1920-luvulla tehtyihin juridisiin uskonnon opetusta koskeviin säädöksiin tehtiin ainoastaan melko vähäisiä muutoksia. Tunnustuksellisen uskonnon opetuksen käsitteestä luovuttiin ja se korvattiin käsitteellä oppilaan oman uskonnon opetus. Uusi uskonnonvapauslaki ja sen 
myötä muuttuneet perusopetuslain ja lukiolain säädökset merkitsivät Sepon (2003) mukaan uskonnon opetuksen aseman vahvistumista. Aikaisemmassa, vuoden 1922 uskonnonvapauslaissa todettiin ainoastaan, miten uskonnon opetuksesta saattoi vapautua. Nyt uudessa laissa oikeus saada uskonnon ja elämänkatsomustiedon opetusta määritellään selkeästi perustuslaista käsin. Laki lähtee siitä, että oppilaalla on positiivinen oikeus saada uskonnon opetusta. Oikeus ankkuroituu Euroopan ihmisoikeussopimuksen ja YK:n asiakirjojen ja ihmisoikeuskomission määritelmiin uskonnonvapauden ja uskontokasvatuksen välisestä suhteesta. Niiden mukaan jokaisella on oikeus oppia ja opettaa uskontoaan ja siihen rinnastettavaa vakaumusta. Kaikille tulisi myös järjestää yhtäläiset yhteiskunnalliset edellytykset oman uskonnon tai sitä vastaavan vakaumuksen opiskeluun ja oppimiseen. (Seppo 2003, 8, 179-189.)

Oman uskonnon opetus -ilmaisun katsottiin uskonnonvapauslain uudistuksen yhteydessä kuvaavan paremmin uskonnon opetuksen sisältöjä ja tavoitteita kuin tunnustuksellisuus-termin (vrt. Saine 2000, 181-185; Seppo 2003, 181). Tunnustuksellisuus-termi oli huonosti kouluopetukseen soveltuva. Tulkinnat siitä, mitä tunnustuksellisella uskonnon opetuksella tarkoitettiin, olivat vaihtelevia. Oman uskonnon opetus -ilmaisun katsottiin myös paremmin kuvaavan uskonnon opetuksen opetussuunnitelmien tavoitteita ja sisältöjä. Uskonnon opetuksen luonne oli selvästi viime vuosikymmeninä muuttunut. Uskontokuntasidonnainen aines oli sulautunut lähes kokonaan yleiskristilliseen tai eri uskontoihin ja maailmankatsomuksiin sekä eettisiin järjestelmiin liittyvään ainekseen. Tämä näkyi erityisesti uskonnon opetuksen opetussuunnitelmissa. Esimerkiksi opetussuunnitelman perusteiden (1994) mukaan uskonnon opetuksen keskeisenä tehtävänä oli tarjota tietoa ja kokemusta oman uskonnon merkityksestä ja sen laajoista kulttuurisista ja yhteiskunnallisista vaikutuksista. Opetuksen tavoitteena oli monipuolinen uskonnollinen ja katsomuksellinen yleissivistys. Näin uskonnon opetus oli olennainen ja keskeinen osa koulun yleissivistävää opetusta. Termin muuttamisella tunnustuksellisesta uskonnon opetuksesta oman uskonnon opetukseen ei varsinaisesti pyritty muuttamaan uskonnon opetusjärjestelmää eikä opetuksen luonnetta tai sisältöä. Pikemmin oman uskonnon opetus -termin valinnalla kuvataan osuvammin uskonnon opetuksen nykyistä luonnetta ja sisältöä. (Seppo 2003, 180-181.) TÄSSÄ!

Laissa on 1920-luvulta lähtien turvattu vähemmistöjen oikeudet uskonnon opetukseen. Kansakoulun järjestysmuodon perusteissa säädettiin, että vähintään 20 oppilaan vähemmistölle oli samassa koulussa järjestettävä oman tunnustuksen mukaista uskonnon opetusta, kun huoltajat sitä pyysivät. Myöhemmin lakia sovellettiin myös oppikouluissa (Kähkönen 1976, 13; Saine 2000, 83, 94). Oppilaiden määrä on muuttunut vuosikymmenien kuluessa. Vuoden 1975 kansakoululaissa vähemmistön uskonnon opetusryhmän kooksi vahvistettiin vähintään kahdeksan oppilasta. Peruskoulu-uudistuksen myötä vaaditta- 
va määrä laskettiin viiteen oppilaaseen. Vuonna 1991 vähemmistöuskontoihin kuuluvien oppilaiden uskonnon opetusryhmän minimikoko laskettiin kolmeen oppilaaseen. 1990-luvun lopulta lähtien oppilaiden ei ole tullut enää sijoittua samaan kouluun, vaan koulun ylläpitäjän alueeseen, joka on yleensä kunta. (Kähkönen 1976, 103, 195; Saine 2000, 187, 203.)

Vähemmistöuskontojen opetuksen tilanne muuttui ratkaisevasti 1990-luvun alussa. Vuonna 1994 Opetushallitus hyväksyi ensimmäiset vähemmistöuskontojen opetussuunnitelmat. Vuoden 1997 loppuun mennessä hyväksyttiin seuraavien vähemmistö- eli pienryhmien uskonnon opetussuunnitelmat: katolinen uskonto, islamin uskonto, adventistinen uskonto, Kristiyhteisön uskonto ja Bahai-yhteisön uskonto (Pyysiäinen 2000, 4). Vuonna 2006 Opetushallitus hyväksyi edellisten lisäksi buddhalaisen, Krishna-yhteisön, Myöhempien Aikojen Pyhien Jeesuksen Kristuksen Kirkon sekä Vapaakirkon uskonnon opetussuunnitelmat (Opetushallitus 2006). Näin suomalainen uskonnon opetustodellisuus on kahdessa vuosikymmenessä muuttunut kirjavaksi ja moninaiseksi.

Eri uskonnon opetuksen muotoihin osallistuminen ei kuitenkaan ole ollut kovinkaan laajaa. Tilastokeskuksen tekemän kartoituksen mukaan peruskoulun syksyllä 2005 aloittaneista oppilaista noin $94 \%$ opiskeli evankelisluterilaista uskontoa, ortodoksista uskontoa opiskelevia oli runsas prosentti ja muita uskontoja opiskelevia oli myös runsas prosentti. Elämänkatsomustietoa opiskeli noin kaksi prosenttia oppilaista ja vajaa prosentti ei osallistunut lainkaan uskonnon ja elämänkatsomustiedon opetukseen. (Ojala 2006, 20.)

Ilmeistä on, että uuden uskonnonvapauslain säätäminen vakiinnutti suomalaisen uskonnon opetusmallin pysymisen nykyisen kaltaisena seuraaviksi vuosiksi. Suomalaisessa yhteiskunnassa on kuitenkin edelleen olemassa selviä paineita mallin kehittämiseksi ja uudenlaisten oppiaineiden opetukseen liittyvien mallien rakentamiseksi (ks. Räsänen 2006, 10). Uskonnon didaktiikan tutkijat ja kehittäjät ovat viime vuosikymmeninä pohtineet suomalaisen mallin kehittämistä (ks. esim. Nyyssönen 1998; Pyysiäinen 2000; Kallioniemi 2003b).

Peruskoulu-uudistuksen aikana Suomessa keskusteltiin laajasti yhteiskunnan antaman uskonnon opetuksen tehtävistä ja organisointiperiaatteesta. Kähkönen (1976, 242-249) tarkasteli kyseistä keskustelua ja esitti sen pohjalta viisi perusmallia, jonka pohjalta uskonnon opetus voidaan toteuttaa tai jättää toteuttamatta. Vaikka Kähkösen tutkimus perustuu 1960- ja 1970-luvun tilanteeseen, niin silloin esitetyt perusratkaisut ja -mallit ovat edelleen ajankohtaisia (esim. Räsänen 2006, 22-24):

1. koulu, jossa ei ole yhteiskunnan antamaa uskonnon opetusta, mutta jossa kuitenkin olisi uskonnollisten yhdyskuntien järjestämää vapaaehtoista uskonnon opetusta koulupäivien aikana 
2. koulu, jossa on kaikille oppilaille yhteinen tunnustukseton, objektiivinen uskonnon opetus

3. koulu, jossa on tunnustuksellista eli uskontokuntasidonnaista uskonnon opetusta

4. valinnainen uskonnonopetus

5. uskonnon opetus on vapaaehtoinen oppiaine

Ensimmäisessä mallissa on useita eri vaihtoehtoja: a) koulujärjestelmässä ei ole uskonnon opetusta eikä muutakaan katsomusopetusta, mutta uskonnollisten yhdyskuntien tehtävänä on järjestää vapaaehtoista uskonnon opetusta, b) uskonnon tilalla annetaan kaikille yhteistä, esimerkiksi elämänkatsomustiedon ja aatteiden opetusta, c) uskontokuntien tehtävänä on järjestää vapaaehtoista uskonnon opetusta ja uskonnon tilalla opetetaan kaikille yhteisenä oppiaineena uskontojen historiaa tai etiikkaa, vapaaehtoinen uskonnon opetus olisi uskontokuntien tehtävä (esim. Räsänen 2006, 22-24).

Ensimmäinen Kähkösen (1976) esittämistä vaihtoehdoista ei sovellu suomalaiseen kontekstiin. Uskonnon opetus kuuluu olennaisena osana koulun yleiseen tehtävään yhteiskunnassa. Oppiaineen opetus on välttämätöntä, koska uskonto on osa sitä todellisuutta, jonka keskellä lapset ja nuoret kasvavat. Viime vuosina koulun uskonnonopetuksessa ja sen kehittämisessä on ollut esillä erilaisia painotuksia: 1. etiikkaan ja elämänkatsomuksen muodostumiseen liittyvä painotus, 2. kulttuuriperintökasvatukseen liittyvä painotus, 3. kansalaiskasvatukseen liittyvä painotus sekä 4. monikulttuuriseen ja moniuskontoiseen yhteiskuntaan liittyvä painotus. (Kallioniemi 2007.)

Eri painotukset avaavat uskonnon opetuksen tehtävää koulussa. Ne osoittavat, miten moninainen oppiaine on. Uskonnon opetus voi avata omaan kulttuuriin liittyvää perintöä. Toisaalta taas se antaa valmiuksia elää demokraattisessa kansalaisyhteiskunnassa. Oppiaineen opetus voi liittyä kiinteästi oppilaan omaan elämään, etiikkaan ja elämänpolitiikan rakentamiseen. Oppiaine voi myös merkittävällä tavalla lisätä oppilaiden tietoisuutta eri tavalla ajattelevien ja uskovien ihmisten elämästä ja elämäntodellisuudesta. (Kallioniemi 2007.)

Uskonnon opetuksen merkitys kehittyvän oppilaan ja yhteiskunnan näkökulmasta on kiistaton. Oppilaat tarvitsevat uskonnon opetuksen antamia valmiuksia kasvussaan tasapainoisiksi aikuisiksi. Monipuolinen henkinen kehittyminen edellyttää elämän henkisen ja uskonnollisen ulottuvuuden tuntemista. Yhteiskunta tarvitsee uskonnon opetusta ylläpitääkseen omaa kulttuuriperintöään sekä eettisiä periaatteitaan sekä opettaessa lapsille ja nuorille valmiuksia elää dialogissa uskonnollisesti erilaisten ihmisen kanssa. (Kallioniemi 2007.)

Kähkösen (1976) esittämää toista vaihtoehtoa, jossa Suomessa siirryttäisiin kaikille oppilaille yhteiseen tunnustuksettomaan oppiaineeseen, on väläytetty useita kertoja uskonnon opetuksen kehittämiseen liittyvässä keskustelussa. 
Vastaavankaltaiseen vaihtoehtoon on siirrytty muissa Pohjoismaissa: Ruotsissa vuonna 1962, Tanskassa vuonna 1975 ja Norjassa 1997 (ks. esimerkiksi Selander 1999, 66-71).

Ajatusta on usein perusteltu sillä, että tämän vaihtoehdon mukainen uskonnon opetus olisi puolueetonta ja objektiivista. Vaihtoehtoon siirtyminen ei kuitenkaan ole ongelmatonta: opetus ei voi koskaan olla puolueetonta ja objektiivista, vaan opetus tapahtuu aina tietyssä sosiaalisessa kontekstissa, jossa samalla välitetään asenteita ja arvoja. Ongelmaksi voisi myös muodostua tällaisen opetuksen sisällöt eli oppiaineksen valinta. (Pruuki 2003.)

Uskonnon opetuksen laaja-alaiset ja monipuoliset tavoitteet monikulttuurisessa yhteiskunnassa edellyttävät, että oppilaat harjaantuisivat koulussa aitoon dialogiin ja keskinäiseen ymmärrykseen erilaisen uskonnollisen ja katsomuksellisen taustan omaavien oppilaiden kanssa. Tästä näkökulmasta toisen vaihtoehdon kaltainen uskonnon opetus voisi olla perusteltua. Vaihtoehdon toteutumiseen liittyy kuitenkin useita vaikeita kysymyksiä, kuten esimerkiksi missä määrin eri katsomuksiin kuuluvien oppilaiden vanhemmat hyväksyisivät tämänkaltaisen uskonnon opetuksen? Perustellusti voidaan kysyä, mitä todellisia mahdollisuuksia yhteiskunnassamme on rakentaa yleissivistävään kouluun oppiaine, joka ei olisi yhteydessä mihinkään uskonnolliseen yhteisöön.

Kolmas Kähkösen (1976) esittämistä vaihtoehdoista jatkaa nykyistä suomalaista linjaa. Nykyisen mallin jatkamiseen liittyy useita erilaisia näkökulmia. Vaihtoehto ottaa erittäin hyvin huomioon uskonnolliset vähemmistöt ja turvaa tavallaan heidän oikeutensa saada oman uskonnon opetusta. Vaihtoehto on erinomainen, jos katsotaan, että lapsilla ja nuorilla tulisi olla valmiudet oman uskonnollisen identiteettinsä työstämiseen. Vaihtoehdon jatkuminen synnyttää kysymyksen siitä, missä määrin yhteiskunnan tehtävä on vastata eri uskonnon opetuksen muotojen toteuttamisesta. Varsinkin, jos samassa koulussa opetetaan lähes kymmentä eri uskonnon opetuksen muotoa. Vaihtoehdon jatkamiseen sisältyy myös mahdollisuus, että uskonnon opetus siirretään uskonnollisten yhdyskuntien toteuttamaksi ja elämänkatsomustiedosta luodaan yhteinen, kaikille oppilaille tarkoitettu oppiaine, jolloin lähestytään Kähkösen (1976) esittämistä vaihtoehdoista ensimmäistä.

Neljäs ja viides Kähkösen (1976) esittämistä vaihtoehtoista ovat uskonnon opetuksen laaja-alaisten ja monipuolisten tavoitteiden näkökulmasta melko soveltumattomia suomalaisen koululaitoksen uskonnon opetusmalleiksi. Uskonnon opetuksen sijoittaminen vapaaehtoiseksi tai valinnaiseksi aineeksi ei ole toimiva ratkaisu, jos tarkastellaan uskonnon opetuksen tavoitteita erityisesti moniuskontoisen yhteiskunnan ja kansalaiskasvatuksen näkökulmasta. Moniuskontoisessa yhteiskunnassa on välttämätöntä, että oppilaat saavat yleissivistävän koulutuksensa yhteydessä monipuoliset valmiudet tarkastella erilaisia elämän uskonnolliseen ja katsomukselliseen ulottuvuuteen liittyviä 
kysymyksiä. Uskonnon opetuksella on laajat yhtymäkohdat myös kansalaiskasvatukseen ja demokratian toteuttamiseen. Siksi siirtyminen vaihtoehtoon, jossa uskonnon opetus olisi valinnaista tai vapaaehtoista, ei ole relevantti. Kansainvälisessä uskonnon didaktisessa tutkimuksessa uskonnon opetuksen yhdeksi keskeisimmistä tavoitteista on asetettu uskonnollisen ja katsomuksellisen kompetenssin saavuttaminen.

Kähkösen (1976) esittämien vaihtoehtojen lisäksi voidaan hahmottaa ainakin yksi toisenlainen vaihtoehto. Siinä osa uskonnon opetuksesta opetettaisiin kaikille oppilaille yhteisenä oppiaineena. Yhteiseen osaan kuuluisivat uskonnon opetuksen yleissivistävät elementit, jotka ovat välttämättömiä suomalaisen kulttuuriperinteen ymmärtämiseksi sekä eri uskontoihin ja katsomuksiin liittyvät yleissivistävät elementit. Omaan uskontoon ja katsomukseen liittyvät elementit opetettaisiin sen sijaan eriyttäen. Tämänkaltainen vaihtoehto on esillä esiopetuksen opetussuunnitelman perusteissa vuodelta 2000. Siinä kulttuurisen katsomuskasvatuksen alla opetetaan uskonnon opetuksen kulttuurisesti keskeisiä sisältöjä ja uskontokasvatuksen alla taas omaan uskontoon liittyvää erityisainesta. (Esiopetuksen opetussuunnitelman perusteet 2000). Ilmeistä kuitenkin on, että tämänkaltainen lähestymistapa ei toimi esiopetuksen arjessa.

Vaihtoehto tulee lähelle Schweitzerin (2005) esittämä dialogimallia, jossa opetus tapahtuu sekä oppilaiden oman uskonnon mukaisissa ryhmissä että yhteisissä integroiduissa ryhmissä. Dialogiryhmissä oppilaat kokoontuisivat yhteen oppimaan toinen toisiltaan ja jakamaan kokemuksiaan toistensa kanssa.

\section{Uskonnon opetuksen uudistus Norjassa - mahdollinen kehityspolku Suomessa}

Seuraavassa tarkastellaan uskonnon opetuksessa 1990-luvulla tapahtunutta muutosta Norjassa. Norjan tilanteen tarkastelu tarjoaa kiintoisia näkökulmia suomalaiseen keskusteluun uskonnon opetuksesta. Suomella ja Norjalla on yhteisiä tekijöitä, jotka vaikuttavat toisaalta uskonnon opetuksen asemaan yhteiskunnassa ja toisaalta taas keskusteluun uskonnon opetuksen luonteesta, tehtävästä ja yhteiskunnan koululaitokseen soveltuvasta uskonnon opetusmallista. Suomen ja Norjan uskonnollinen ilmapiiri on samankaltainen. Uskonnon rooli ja asema näissä maissa on samantyyppinen. Suomalainen ja norjalainen koulujärjestelmä on samankaltainen. Uskonnon opetuksen historiallinen kehitys Suomessa ja Norjassa on ollut melko yhteneväistä, lukuun ottamatta aivan viimeisiä vuosikymmeniä. Molemmissa maissa luterilaisella kirkolla on ollut merkittävä rooli kansanopetuksen kehittymisessä. Uskonnon opetuksella oli pitkään 1900-luvulle asti sekä Suomessa että Norjassa katekeettinen tehtävä: 
oppiaineen tavoitteena oli kasvattaa luterilaisia kristittyjä ja saavuttaa positiivinen asenne luterilaista oppia kohtaan. (Selander 1999, 54, 74; Kallioniemi 2005c, 287.)

Norjassa uskonnon opetuksen asemasta, luonteesta ja sisällöstä on viime vuosikymmenien aikana keskusteltu paljon. Vuoteen 1969 asti uskonnon opetus oli Norjassa päälähtökohdaltaan kristillistä kasvatusta, jota annettiin luterilaisen kirkon jäseniksi kastetuille lapsille. Vuonna 1969 annetussa kasvatuslaissa säädettiin 9-vuotinen peruskoulu. Kasvatuslain uudistuksen yhteydessä keskusteltiin laajasti uskonnon opetuksen asemasta ja tehtävästä. Oppiaineen todettiin perustuvan luterilaiseen uskoon, sillä $95 \%$ norjalaisista kuului luterilaiseen valtionkirkkoon. Kasvatuslaissa todettiin, että koulun tehtävänä on antaa lapsille kristillinen ja moraalinen kasvatus yhteistyössä kotien kanssa ja kotikasvatusta ymmärtäen. Opetus oli luonteeltaan tunnustuksellista. (Afdal, Haakedal \& Leganger 1997, 105-107; Haakedal 2000, 91.)

Uskonnon opetuksen luonne nousi keskustelun kohteeksi jälleen 1990-luvun alkupuolella, kun Norjassa pohdittiin uskonnon opetuksen uudistamista. Afdal, Haakedal ja Leganger (1997) kuvaavat viime vuosina Norjassa tapahtunutta kehitystä, jota heidän mukaansa voidaan luonnehtia yhden aineen mallista rinnakkaisten aineiden mallin kautta yhteiseen malliin. Vuoteen 1974 asti uskonto oli kaikille yhteinen aine. Tuolloin vieraat uskonnot uskonnon oppiaineksena siirrettiin osaksi yhteiskuntaopin opetusta ja tuli mahdolliseksi valita uusi oppiaine 'orientaatio elämänkysymyksiin', joka kehitettiin alun perin vapaaehtoiseksi oppiaineeksi lukioastetta vastaavan koulun oppilaille. Tällöin päätettiin, että se soveltuu oppiaineeksi myös niille oppilaille, jotka olivat vapautettuja uskonnon opetuksesta. Oppiaineesta tuli nopeasti ainoa vaihtoehto uskonnon opetukselle 1970- ja 1980-luvuilla. Afdal \& al. 1997, 105-107; Haakedal 2000, 93, 94.)

Vuonna 1987 uudistetuissa kansallisissa ohjeissa oppiaine 'orientaatio elämänkysymyksiin' sijoitettiin uskonnon opetuksen jälkeen ja vieraat maailmanuskonnot tulivat takaisin uskonnon opetuksen oppisisällöiksi. Samalla tapahtui selvä pedagoginen siirtymä oppiainekeskeisestä opetuksesta temaattiseen opetukseen. Ohjeet antoivat yksittäisille opettajille ja kouluille melko suuren vapauden uskonnon opetuksen sisältöjen laadinnassa. Vuoden 1987 ohjeet sisälsivät paradoksaalisen tilanteen norjalaisen yhteiskunnan ymmärtämisen kannalta. Kun vieraita uskontoja alettiin opettaa uudelleen uskonnon opetuksen yhteydessä, niin uskonnon opetuksesta vapautetut oppilaat, jotka eivät osallistuneet 'orientaatio elämänkysymyksiin' oppiaineen opetukseen, eivät tutustuneet vieraisiin uskontoihin missään oppiaineessa. (Haakedal 2000, 92.)

Norjassa kävi 1990-luvun alussa ilmeiseksi, että rinnakkaisten oppiaineiden malli oli soveltumaton muuttuneessa yhteiskunnallisessa ja kulttuurisessa tilanteessa, vaikka Norja on ollut muihin Euroopan maihin verrattuna melko 
monokulttuurinen maa sekä etnisesti että uskonnollisesti. Tilanne on kuitenkin muuttunut melko nopeasti. Esimerkiksi Oslossa ja sen ympäristössä asui 1990-luvun puolivälissä lähes 50000 islamilaista, joiden lapsista pääosa oli vapautettu uskonnon opetuksesta. Heistä ei kuitenkaan juuri kukaan osallistunut vaihtoehtoisen 'orientaatio elämänkysymyksiin' -oppiaineen opetukseen. Kyseisen oppiaineen suosio jäi myös varsin alhaiseksi; esimerkiksi vuonna 1993 siihen osallistui oppilaista kokonaisuutena vain 4 prosenttia. (Haakedal 2000, 92-93; Hagesather \& Sandsmark 2006, 77.)

Vuonna 1997 uskonnon opetuksen ja 'orientaatio elämänkysymyksiin' oppiaineen pohjalta rakennettiin uusi yhdistetty oppiaine, jossa ei enää ollut tunnustuksellista ainesta. Oppiaineen nimeksi tuli Kristinusko ja orientaatio elämänkysymyksiin. Opetusministerin rooli uuden oppiaineen profiloimisessa oli merkittävä: hän katsoi, että jokaisen tulisi tietää kristinuskon kulttuuriperinnöstä ja muista uskonnoista sekä sekulaareista elämänkatsomuksista. Opetusministerin mukaan yhteinen oppiminen antoi yhteisen kulttuuri-, tieto- ja arvoperustan ja kasvatti erilaisuuden sietokykyä ja kunnioitusta erilaisuutta kohtaan. Oppiaineessa tulisi myös olla tilaa tärkeiden eettisten kysymysten tarkastelulle. (NOU 1995:9.) Näin oppiaine profiloituu eräänlaiseksi kansalaisuskonnon ilmentymäksi, jossa painotetaan kansallista perintöä ja moraalisia arvoja (Skeie 2006, 22).

Uskonnon opetukseen osallistumista ei enää sidottu kirkon jäsenyyteen: kaikki uskonnot esiteltiin "sisältäpäin" ja uskonnon opetuksen lähtökohdaksi asetettiin oppilaiden persoonallinen kehitys. Oppiaine nähdään ensisijaisesti koulun oppiaineena ja kaikki, mitä uskonnon opetuksessa tapahtuu, tulee tapahtua koulun lähtökohdista käsin - ei kirkon tai muiden uskonnollisten yhdyskuntien intressien pohjalta. Oppiaine nähdään monikulttuurisessa yhteiskunnassa keskeiseksi välineeksi yhteiskunnan kansallisen hengen saavuttamisessa. Oppiaineen perustehtävänä on antaa oppilaille yhteinen tieto, kulttuuri ja arvoperusta. Opetussuunnitelman laadinnan lähtökohtana on, että oppiaine on objektiivinen, neutraali ja pluralistinen. Kaikkia uskontoja ja elämänkatsomuksia tulee kohdella tasa-arvoisesti. Kaikkia lapsia tulee tukea heidän identifioitumisessaan omaan uskonnolliseen traditioonsa. Näitä pedagogisia lähtökohtia on sovellettava myös kaikkeen uskonnon opetuksen oppimateriaaliin. (Afdal \& al. 1997, 105-107, Haakedal 2000, 94; Skeie 2006, 24.)

Oppiaineen keskeiset sisällöt ovat seuraavat: 1. uskontoihin ja elämänkatsomuksiin liittyvä tieto, 2. suvaitsevaisuus ja dialogi eri uskontojen välillä, 3 . uskonto, kulttuuri ja yhteiskunta, 4. ekumeenisuus sekä 5. eri uskontojen ja katsomusten tasa-arvo ja kasvatukselliset periaatteet, jotka lisäävät uskonnon tuntemusta. Oppiaine on jaettu viiteen eri osa-alueeseen: Raamattutieto, kristinuskon historia, tämän päivän kristillisyys, muut uskonnot ja maailmankäsitykset sekä etiikka ja filosofia. Raamattutiedon tavoitteena on, että oppilaat 
tuntevat tiettyjä raamatun peruskäsitteitä. Kristinuskon historian opetuksen tavoitteena on, että oppilaat perehtyvät kristinuskon päähistoriaan, keskeisiin henkilöihin ja erilaisiin uskonnon ilmenemismuotoihin. Tämän päivän kristillisyydessä oppilaat tutustuvat norjalaisen luterilaisuuden lisäksi myös muihin tunnustuskuntiin ja traditioihin sekä ei-eurooppalaiseen kristillisyyteen. Oppilaat tutustuvat myös muihin maailmanuskontoihin kuten islamiin, juutalaisuuteen, buddhalaisuuteen, hindulaisuuteen ja ei-uskonnollisiin liikkeisiin. Eettinen tietoisuus rakentuu itsen ja muiden tarkastelusta yhdistettynä arvoihin ja valintojen tekemiseen. (Laereplanverket for den 10-årige grunnskolen 96, 91-92.)

Vaikka Kristinuskosta ja orientaatiosta elämänkysymyksiin tuli oppilaille pakollinen aine, laki kuitenkin antoi oppilaille mahdollisuuden vapautua sellaisista uskonnollisista toiminnoista, jotka heidän vanhempiensa mielestä olivat uskonnollisista tai katsomuksellisista syistä toisen uskonnon harjoittamista tai kuuluvan heidän vakaumuksestaan poikkeavaan katsomukseen. Tämä tarkoittaa käytännössä, että oppilaiden ei tarvitse laulaa virsiä, rukoilla, yhtyä uskontunnustukseen tai vierailla kirkoissa tai muissa uskonnollisissa rakennuksissa eikä myöskään osallistua uskonnollisiin toimintoihin, jotka ovat heidän mielestään heidän katsomuksensa vastaisia. Mutta oppilaiden tulee kuitenkin opiskella kaikkia sisältöjä. (Hahesather \& Sansmark 2006, 278.) Periaatetta, jonka mukaisesti oppiaineen opetuksesta voi saada vain osittaisen vapautuksen, on voimakkaasti kritisoitu.

Vuonna 2002 oppiaineen opetukseen tehtiin joitakin muutoksia. Tätä edelsi laaja kansallinen arviointitutkimus, jossa oppiaineen opetusta tarkasteltiin eri näkökulmista. Arvioinnin tehtävänä oli muun muassa selvittää, miten oppiainetta opetetaan, miten oppiaineen opetuksesta vapauttamista toteutetaan käytännössä sekä millaisia mahdollisuuksia lasten vanhemmilla oli toteuttaa kasvatusoikeuttaan tämän oppiaineen yhteydessä. Opetussuunnitelma-analyysin pohjalta oppilailta, heidän vanhemmiltaan ja opettajilta tiedusteltiin heidän kokemuksiaan oppiaineesta. Oppilaiden vanhemmilta kysyttiin myös, minkälaista koulun uskonnon opetuksen ylipäätänsä tulisi olla. Tutkimukseen osallistui noin 1500 oppilasta ja 1500 vanhempaa sekä noin 650 opettajaa. (Hagesather, Sandsmark \& Belka 2000, 9.)

Tutkijat suosittivat oppiaineen opetukseen seuraavia muutoksia: 1. laajennettua vapauttamismahdollisuutta oppiaineen opetuksesta, parempia tiedottamiskäytäntöjä sekä oikeutta opettaa osa oppiaineen opetuksesta oppilaiden uskonnon tai maailmankatsomuksen mukaisissa ryhmissä, 2. mahdollisuutta siirtää vasta viidennelle luokalle opetus niistä uskonnoista ja maailmankatsomuksista, joita ei ole lapsen paikallisyhteisössä sekä 3. koordinoivia ohjeita ja sääntöjä, jotka mahdollistavat yksinkertaisimman käytännön vapauttamiseen oppiaineen opetuksesta sekä ohjeita ja sääntöjä oppiaineen sisällöstä ja 
oppiaineen sisältöjen vähentämisen. Tutkijoiden suositukset johtivat useisiin muutoksiin. Uuteen opetussuunnitelmaan otettiin vähemmän sisältöainesta ja se mahdollisti sellaisten uskontojen ja katsomusten opettamisen vasta viidenneltä luokalta alkaen, joita ei ollut lapsen paikallisyhteisössä. Samalla annettiin myös ohjeita siitä, minkälainen painotus oppiaineen eri sisältöalueiden suhteessa on sekä annettiin selkeitä menettelytapaohjeita uskonnon opetuksesta vapauttamiseksi. (Hagesather, Sandsmark \& Belka 2000, 154-161; Hagesather \& Sandsmark 2006, 283)

Maan hallitus näki yhteisen, pakollisen oppiaineen olevan paras tapa antaa oppilaille yhteinen pohjatieto kulttuurista ja arvoista sekä edistää erilaisten ihmisen ymmärtämistä, kunnioitusta ja dialogia erilaisen uskonnollisen taustan ja maailmankatsomuksen omaavien ihmisten välillä. Tämä heikensi vanhempien toivetta siitä, että oppilaat voitaisiin vapauttaa uskonnon opetuksessa muustakin kuin tietyistä uskonnollisista aktiviteeteistä. Päätös tuo esiin oppiaineen keskeisimmän ongelman: miten koulu voi antaa oppilaille samanaikaisesti yhteisen kulttuurisen pohjan ja ottaa huomioon vanhempien oikeuden uskonnonvapauteen. (Hagesather \& Sandsmark 2006, 283.)

Eräiden lasten vanhemmat olivat varsin tyytymättömiä maan hallituksen linjaukseen ja valittivat päätöksestä oikeuteen. Hävittyään oikeuskäsittelyn Norjassa neljän oppilaan vanhemmat valittivat Euroopan ihmisoikeuskomissioon vuonna 2003. Euroopan ihmisoikeuskomissio tuki vanhempien vaatimuksia. Päätöslauselmassaan ihmisoikeuskomissio viittasi yleisjulistukseen, jonka 18.4 artiklassa todetaan muun muassa, että 'se sallii yleisten koulujen opetuksen uskontojen historiasta ja etiikasta, jos sitä annetaan neutraalisella ja objektiivisella tavalla.' Koulun yleinen opetus, joka käsittää yksittäisen uskonnon tai uskomuksen opetuksen, on ristiriidassa edellisen kanssa, jos oppilaita ei voida siitä vanhempien vaatimuksesta vapauttaa. Tämän seurauksena kasvatuslakia muutettiin vuonna 2005. Vapauttaminen ulotettiin kaikkiin muihinkin koulun oppiaineisiin ja opetukseen, joka koetaan uskonnollisesta näkökulmasta loukkaavaksi. Ongelmana on ollut, että oppilaille tulisi järjestää korvaavaa opetusta. Selvää on kuitenkin, että kaikki vanhemmat eivät olleet tähän ratkaisuun tyytyväisiä. Uusi opetussuunnitelma annettiin syksyllä 2005. Tämä painottaa huomattavasti enemmän tavoitteita kuin itse sisältöjä. Keskustelu uskonnon opetuksen luonteesta ja tehtävästä on jatkunut Norjassa tehdyistä uudistuksista huolimatta. (Hagesather \& Sandsmark 2006, 283-285.)

Norjassa tapahtunut uskonnon opetuksen uudelleen muotoutuminen osoittaa, että uskonnon opetuksen kysymykset ovat problemaattisia ja liittyvät monella tavalla ihmisoikeuksiin ja vanhempien kasvatusoikeuteen. Norjalainen oppiaineen uudelleen muotouttamisprosessi osoittaa myös, miten moninaisesta ilmiöstä uskonnon opetuksessa on viime kädessä kysymys. 


\section{Lopuksi}

Eurooppalaisten uskonnon opetusratkaisujen tarkastelu avaa mahdollisuuksia suomalaisen mallin kehittämiseksi. Kehittämistyössä on erittäin tärkeää tuntea eri maissa toteutettujen mallien heikkouksia ja vahvuuksia. Uskonnon opetuksen tarkastelu eurooppalaisella tasolla tuo selkeästi esille eri maiden historialliset ja kulttuuriset piirteet, jotka vaikuttavat kunkin maan uskonnon opetustraditiossa. Käytännössä on mahdotonta ennustaa, mihin suuntaan suomalainen uskonnon opetus on kehittymässä. Uskonnon opetuksen uudistaminen ja suomalaisen mallin kehittäminen liittyvät moniulotteisesti suomalaisen yhteiskunnan rakenteeseen ja muutokseen sekä koulutuspolitiikkaan.

Uskonnon opetuksen on elettävä kiinteässä yhteydessä siihen kontekstiin, jossa opetus tapahtuu. Oppiaineen kehittämisessä on otettava lähtökohdaksi se sosiaalinen ja kulttuurinen konteksti, jossa uskonnon opetus tapahtuu. Uskontoa opetetaan yhteiskunnan ylläpitämässä koululaitoksessa. Suomalainen uskonnon opetustraditio on ollut läheisessä vuorovaikutuksessa kirkkojen kasvatustoiminnan kanssa. Sen keskeisen tieteenalastruktuurin ovat muodostaneet teologiset tieteet. Viime vuosikymmeninä suomalaisessa yhteiskunnassa on tapahtunut lukuisia muutoksia muun muassa monikulttuuristumisen ja maallistumisen myötä. Uskontoa kouluaineena tulisi Suomessa tarkastella ja kehittää nimenomaan muuttuvasta yhteiskunnasta käsin. Oppiaineen kehittämisen lähtökohdaksi tulisi ottaa kasvatustieteellis-sosiaalitieteellinen näkökulma, jossa painotettaisiin uskonnon opetuksen merkitystä toisaalta kasvavan ja kehittyvän nuoren persoonahistoriallisista lähtökohdista käsin, toisaalta taas uskonnolliseen kompetenssiin liittyvistä uskonnolliseen ja katsomukselliseen yleissivistykseen liittyvistä lähtökohdista käsin.

\section{Lähteet}

Afdal, G., Haakedal, E. \& Leganger-Korgstad, H. (1997). Tro, livstolkning og trandisjon. Oslo: Tano Aschehoug As.

Arthur, J. \& Wright, D. (2001). Teaching Citizenship in the Secondary School. London: David Fulton Publishers.

Council of Europe. (1999). Recommendation 1397. Religion and Democracy.

Davie, G. (2000). Religion in Modern Europe. A Memory of Mutates. New York: Oxford University Press.

Esiopetuksen opetussuunnitelman perusteet 2000. Opetushallitus: Helsinki.

Haakedal, E. 2000. From Lutheran Catechism to World Religions and Humanism: Dilemmas and Middle Ways through the Story of Norwegian Religious Education. British Journal of Religious Education, 22 (2), 88-97. 
Hagesather, G., Sandsmark, S. \& Belka, D.-A. (2000). Forelder, lareres og elevers erfaring med KRL-laget. Bergen: NLA-forlaget.

Hagesather, G. \& Sandsmark, S. (2006). Compulsory Education in Religion-The Norwegian Case: An Empirical Evalutations of RE in Norwegian Schools with a Focus on Human Rights. British Journal of Religious Education, 28 (3), 275287.

Heimbrock, H.-G., Sheilke, C. \& Schreiner, P. (2001). Introduction. In Heimbrock, H.-G., Sheilke, C. \& Schreiner, P. (toim.), Towards Religious Competence. Diversity as a Challenge for Religious Education in Europe. Schriften aus dem Comenius-Institut, 9-23. Munster: Lit.

Heimbrock, H.-G. (2004). Europe as a Basic and as a Challenge for Religious Education Research. In Larson, R. \& Gustavsson, G. (toim.), Towards a European Perspective on Religious Education. Biblioteheca Theologiae Practica 74, 90101. Lund: Artos \& norma bokförlag.

Hobson, P. R. \& Edwards, J. S. (1999). Religious Education in Pluralistic Society. London: Woburn Press.

Hull, J. M. (2001). The Contribution of Religious Education to Religious Freedom: A Global Perspective. In Religious Education in Schools: Ideas and Experiences from around World, 1-8. International Association for Religious Freedom,.

Hull, J. M. (2002). Understanding contemporary European consciousness: An approach through geo-politics. Panorama, 12 (2), 123-140.

Jackson, R. (2003). Citizenship, Religious and Cultural Diversity and Education. In Jackson, R. (ed.), International Perspectives on Citizenship, Education and Religious Diversity, 1-28. London: RoutledgeFalmer.

Kallioniemi, A. (2003a). Eurooppalaisia uskonnon opetusmalleja ja skenaarioita suomalaisen mallin kehittämiseksi. Teoksessa Virta, A. \& Marttila, O. (toim.), Opettaja, asiantuntijuus ja yhteiskunta. Turun yliopiston kasvatustieteiden tiedekunnan julkaisuja B:72, 369-375. Turku: Painosalama.

Kallioniemi, A. (2003b). Uskontokasvatus varhaiskasvatuksen tutkimuksen kentässä. Teoksessa Kallioniemi, A., Räsänen, A. \& Hilska, P. (toim.), Lapsen sielun maisema. Studia Paedagogica 30, 91-106. Helsinki: Hakapaino.

Kallioniemi,A.(2005a). Uskonnon opetus ja uskontokasvatus historiallis-yhteiskunnallisessa kontekstissa. Teoksessa Kallioniemi, A. \& Luodeslampi, J. (toim.), Uskonnon opetus uudella vuosituhannella, 11-49. Helsinki: Kirjapaja.

Kallioniemi, A. (2005b). Uskonnon opetuksen haasteet kulttuurisessa murroksessa. Didacta Varia 10 (1), 51-60.

Kallioniemi, A. (2005c). Uskonnon opetus Skandinavian maissa ja Suomessa 1990-luvun opetussuunnitelmien valossa. Teoksessa Virta, A., Merenluoto, K. \& Pöyhönen, P. (toim.), Ainedidaktiikan ja oppimistutkimuksen haasteet opettajankoulutukselle. Turun yliopiston kasvatustieteiden tiedekunnan julkaisuja B:75, 286-294. Turku: Painosalama.

Kallioniemi, A. (2006a). Muuttuva yhteiskunta ja uskontokasvatus. Kristillinen kasvatus 2, 2006, 15-17. 
Kallioniemi, A. (2006b). Religious education curricula in comprehensive schools in Scandinavia and Finland in the 1990's. In Tirri, K. (toim.), Nordic Perspectives on Religion, Spirituality and Identity. Yearbook 2006 of the Department of Practical Theology, 75-88. Jyväskylä: Gummeruksen kirjapaino.

Kallioniemi, A. (2007). Uskonnonopetus alakoulussa. Teoksessa Luodeslampi, J. \& Nevalainen, S. (toim.), Opetan uskontoa. Helsinki: Lasten keskus.

Kodelja, Z. (2004). Comparative Information on Approaches to Religious Education. Unprinted material. Centre for Philosophy of Education, Education Research Institute, Slovenia.

Kodelja, Z. \& Bassler, T. (2004). Religion and Schooling in Open Society. A Framework for Informed Dialogue. Open Society. Slovenia: Ljubljana.

Kähkönen, E. (1976). Uskonnon opetuksen asema Suomen koulunuudistuksessa 19441970. Suomalaisen teologisen kirjallisuusseuran julkaisuja 101. Helsinki: STKS.

Laki 18.5.1923/137. Laki kansakoulun järjestysmuodon perusteista. Ask.

Laereplanverket for den 10-årige grunnskolen (1996). Det kongelige kirke-, utdannings- og forskningsdepartement.

NOU 1995:9. Identitet og dialog. Oslo: Statens forvaltingstjeneste.

Nyyssönen, S. (1998). Uskonnon opetuksen tulevaisuuden näkymät. Teoksessa: Pyysiäinen, M. \& Seppälä, J. (toim.). Uskonnonopetuksen käsikirja, 458-466. Juva: WSOY.

Ojala, U. (2006). Pienryhmäläisille uskonnoille uudet ops-perusteet. Opettaja 40/2006, 20.

Olivestam, C. E. (2006). Religionsdidaktik - om teori, perspektiv och praktik i religionsundervisingen. Stockholm: Liber AB.

Opetushallitus. (2006). Perusopetuksen muiden uskontojen opetussuunnitelmat.

Orlenius, K. (1995). Religionsämnet i Sverige. Religion og livssyn. Tidskrift for Religionslaererforening $i$ Norge 7 (4), 35-37.

Plesner, I. T. (2001). Hvordan definer felleskapets gruunlag?. Om pluraliseringens betydning for offentlig religionsundervisinig. I Henriksen, J.-O. (red.), Identitet og pluralitet, 131-182. Oslo: Gyldendal.

Plesner, I. T. (2002). Religio-political models and models for religious and moral education. Panorama, 14(2), 111-122.

Pruuki, L. (2003). Uskonnon opetuksen asema ja luonne suomalaisessa koulujärjestelmässä. Lectio Praecursoria 10.1.2003. http://janua.helsinki.fi/uskonnonpedagogiikka/pruuki vaitos.html, luettu 21.1.2007.

Pyysiäinen, M. (1998). Koulun uskonnon opetuksen luonne. Teoksessa Pyysiäinen, M. \& Seppälä, J. (toim.), Uskonnonopetuksen käsikirja, 41-68. Porvoo: WSOY.

Pyysiäinen, M. (2000). Yksi oppiaine, seitsemän opetussuunnitelmaa. Peruskoulun ja lukion opetushallituksen 1990-luvulla vahvistamien uskonnon opetussuunnitelmien tunnustuksellinen luonne. Helsingin yliopiston opettajankoulutuslaitoksen tutkimuksia 223. Helsinki: Hakapaino.

Räsänen, A. (2006). Koulun uskonnon opetus. Suomalaisten käsitykset uskonnon opetuksen luonteesta ja sisällöstä. Suomalaisen teologisen kirjallisuusseuran julkaisuja 248. Helsinki: Gummerus Kirjapaino. 
Saine, H. (2000). Uskonnon opetus Suomen oppivelvollisuuskouluissa 1900-luvulla. Turun yliopiston julkaisuja. Sarja C, osa 165. Diss. Turku: Painosalama.

Schreiner, P. (1999). Different Approaches to RE/RS in European Schools-The Scandinavian Approach in a European Context. In Tidman, N-A. (ed.), Into the Third Millenium ....EFTRE conference August 1998 in Copenhagen. Föreningen lärare I religionskunskap. Årsbok 1999. ÅRG 31, 113-129. Malmö: Team Offset \& Media.

Schreiner, P. (2001). Towards a European Oriented Religious Education. In Heimbrock, H.-G., Scheilke C. \& Schreiner P. 2001. Towards Religious Competence. Diversity as a Challenge for Education in Europe. Schriften aus dem ComeniusInstitut, 253-269. Munster: Lit.

Schreiner, P. (2002). Overview of Religious Education in Europe. In Schreiner, P., Spinder, H., Taylor, J. \& Westerman, W. (eds.), Committed to Europe's Future. Contributions from Education and Religious Education, 91-95. Comenius-Institut, Protestant Centre for Studies n Education. Monster-Lit.

Schweitzer, F. (2005). Children's Right to Religion: A Challenge to Educational Neutrality? http://www.edu.joensuu.fi/ortoweb/SchweitzerTartu.pdf, luettu 16.1.2007.

Selander, S-Å. (1999). State, Church and School in the Scandinavian Countries-In a European Perspective. In Tidman, N-Å. (ed.), Into the Third Millenium.... EFTRE conference August 1998 in Copenhagen. Föreningen lärare I religionskunskap. Årsbok 1999. ÅRG 31, 54-75. Malmö: Team Offset \& Media.

Seppo, J. (2003). Uskonnonvapaus 2000-luvun Suomessa. Helsinki: Edita.

Skeie, G. (2001). Citizenship, Identity Politics and Religious Education. In Heimbrock, H.-G., Sheilke, C. \& Schreiner, P. (eds.), Towards Religious Compentence. Diversity as a Challenge for Education in Europe. Schriften aus dem ComeniusInstitut, 237-252. Monster: Lit.

Skeie, G. (2006). Diversity and the political function of religious education. British Journal of Religious Education, 28(1), 19-32.

UNESCO, (2003). Education and Religion: the Paths of Tolerance, Prospects, Quarterly Review of Comparative Education, Vol. XXXIII, no.2. UNESCO: IBE.

Valtioneuvosto, (2001). Asetus N:o 1435 perusopetuslaissa tarkoitetun opetuksen valtakunnallisista tavoitteista ja perusopetuksen tuntijaosta. (http://www.finlex. fi/fi/laki/kokoelma/2001/20010197.pdf, luettu 16.1.2007. 


\title{
Kansalaisten käsityksiä peruskoulun uskonnon opetuksesta
}

\author{
Antti Räsänen
}

Tiivistelmä

Uskonto on perusopetuksessa oppiaine, jota opetetaan kodin katsomuksen mukaisissa opetusryhmissä. Suomessa on tutkittu uskonnon opetussuunnitelmia, uskonnon opettajia ja oppilaiden käsityksiä oppiaineesta, mutta kansalaisten tiedot ja käsitykset uskonnon opetuksesta ovat jääneet vähälle huomiolle, mikä on perusteltu syy tutkia aikuisten suomalaisten käsityksiä uskonnon opetuksesta.

Tutkimus toteutettiin lomakekyselynä, johon osallistui 588 iältään 18-80-vuotiasta suomalaista. Tutkimusaineisto käsiteltiin tilastollisin menetelmin, joista tärkeimpiä olivat faktorianalyysi, regressioanalyysi ja monimuuttujainen varianssianalsyysi.

Suomalaiset kannattivat eniten uskontotiedon opettamista. Kristillis-kirkollista kouluopetusta ei laajasti kannatettu, eikä myöskään torjuttu. Uskonnon opetusta ei haluta poistaa koulusta. Uskonnon opetusta perustellaan voimakkaimmin kulttuurihistoriallisin syin. Uskonnon katsotaan myös kuuluvan ihmisolemukseen, millä perusteella uskonto kuuluu koulun oppiaineiden joukkoon. Kansalaiset torjuvat käsityksen, jonka mukaan kirkon (tai jonkin muun uskonnollisen yhdyskunnan) ja koulun kasvatustavoitteet olisivat samat. Uskontoa pidetään tarpeellisena oppiaineena, mutta samalla arvellaan, ettei uskonto ole oppilaitten suosiossa. Uskonnon opetuksen ei katsota rajoittavan kenenkään omantunnon vapautta.

Uskonnon opetuksen yhteistoiminnallisuutta ja dialogisuutta tulisi lisätä tulevaisuudessa. Parhaimmillaan opetus voisi tukea oppilaan oman maailmankuvan kehitystä ja samalla lisätä toisten kunnioittamista.

Avainsanat: uskonnon opetus, uskontokasvatus, peruskoulun oppiaineet, oman uskonnon opetus, yhteistoiminnallinen opetus

\section{Koulu ja uskonto}

Tässä artikkelissa tarkastellaan suomalaisten käsityksiä koulun uskonnon opetuksesta. Kirkko kantoi vastuun kansan lukemaan opettamisesta puhdasoppisuuden kaudelta (1600-luku) aina 1800-luvun loppupuolelle saakka, jolloin maahamme luotiin kunnallinen kansakoulujärjestelmä. Kansaopetuksen jär- 
jestämisen yhteydessä uskonnosta tuli yksi koulun oppiaine. Sen jättämisestä koulussa opetettavien aineiden ulkopuolelle ei edes keskusteltu. Myöhemmin uskonnon opetuksen muoto ja sisältö on ollut suurennuslasin alla monta kertaa.

Tällä hetkellä uskonto on yksi Suomen peruskoulun pakollisista oppiaineista. Koulun oppiaineet on määritelty laissa ja valtioneuvosto on päättänyt oppiaineiden tuntijaosta, jonka mukaan peruskoulun 6-9 luokilla uskonnon tai elämänkatsomustiedon opetusta on viisi vuosiviikkotuntia, joista opetetaan yleensä kolme entisellä yläasteella (luokat 7-9). Yksi vuosiviikkotunti on 38 oppituntia, joten peruskoululainen saa yläasteen aikana 114 tuntia opetusta uskonnossa. Käytännössä se tarkoittaa useimmiten yhtä uskontotuntia viikossa, mikäli opetusta ei ole järjestetty periodeittain tai kurssimuotoisesti. Tuntimääränsä perusteella uskonto lukeutuu melko pienten kouluaineitten joukkoon.

Kouluhallinnon ja opetusjärjestelyiden tasolla uskonnon opetus on varsin selkeästi ohjeistettu kokonaisuus. Uskontoa opetetaan oppilaiden vanhempien tunnustuskunnan mukaisissa opetusryhmissä opetushallituksen hyväksymien opetussuunnitelmien mukaisesti. Uskontokuntiin kuulumattomille oppilaille opetetaan elämänkatsomustietoa. Muodollisesta selkeydestä huolimatta uskonto-niminen oppiaine nousee aika ajoin keskustelun kohteeksi. Uskonnon - eritoten kristinuskon - roolista koulussa keskustellaan esimerkiksi koulun juhlien yhteydessä. Uskonnon opetus herättää tunteita, ja siitä koituu kustannuksia. Kunnat haluavat säästää ja on tullut esille tapauksia, joissa pienryhmäisten uskontojen opettajan palkkaaminen on saattanut ylittää menojaan leikkaavan kunnan kipukynnyksen.

Uskonnon opetuksen ajankohtaisuuden, mielenkiinnon ja tutkimuksessa havaitun aukon täyttämiseksi oli tärkeää tutkia, mitä suomalaiset ajattelevat koulun uskonnon opetuksesta. Suomessa on tutkittu uskonnon opetussuunnitelmia ja uskonnon opettajia. Tavallisten kansalaisten käsitykset uskonnon opetuksesta ovat jääneet vähälle huomiolle, kun taas oppilaiden näkemyksistä meillä on jonkin verran tutkittua tietoa, kuten seuraavat esimerkit osoittavat.

Salosen (1995) laatimassa selvityksessä kerättiin tietoa muun muassa siitä, mitkä ovat peruskoulun yhdeksäsluokkalaisten $(\mathrm{N}=1422)$ mielestä koulun tärkeimmät, kiinnostavimmat, turhimmat ja ikävimmät oppiaineet. Selvityksen tulosten perusteella uskonto ei kuulunut koululaisten mielestä tärkeimpien tai kiinnostavimpien oppiaineitten joukkoon. Uskonto miellettiin heti ruotsin ja fysiikan jälkeen ikävimmäksi oppiaineeksi ja sitä pidettiin kaikista turhimpana kouluaineena. (Salonen 1995, 2-3, 34-37.) Salosen saamia tuloksia voi pitää suuntaa antavina. Selvitys ei täytä tieteellisen tutkimuksen kriteerejä.

Simo Seppo tutki vuonna 1971 julkaistussa väitöskirjassaan abiturienttien asenteita uskonnon opetukseen. Tulosten perusteella oppilaiden ei tarvitse rajoittaa uskonnollisen ilmaisunsa vapautta uskontotunneilla koulutoverien pe- 
lossa, eikä opettajankaan pelossa, sillä oppilaat eivät Sepon mukaan yleensä pelkää tai aristele uskonnon opettajaa. Tytöt tosin ovat hieman arempia kuin pojat. Tytöt olivat Sepon tutkimuksen mukaan keskimääräisesti poikia kiinnostuneempia uskonnon opetuksesta. He ilmaisivat lievää kiinnostusta oppiaineeseen, pojat ilmaisivat lievää kielteisyyttä uskontoa kohtaan. Uskonnon opetuksen poistamisen koulusta tytöt torjuivat, kun taas pojat asennoituivat siihen hieman myönteisemmin. Tutkimuksessa havaittiin, että opetuksen opettajakeskeisyys ja koulun uskonnon opetuksen kokeminen vastenmieliseksi varioivat yhdessä. (Seppo 1970, 39-49.)

Edellä esitettyjen tutkimustulosten valossa on mielenkiintoista selvittää, millaisia ovat suomalaisten aikuisten kokemukset, tiedot ja mielikuvat uskonnosta kouluaineena. Moni asia elämässä muuttuu sen jälkeen, kun kouluvuodet ovat takana.

\section{Kansalaiskysely uskonnon opetuksesta}

Tutkimus toteutettiin lomakekyselynä syksyllä 2004. Tavoitteeksi asetettiin selvittää suomalaisten tietoja, kokemuksia, mielikuvia ja uskomuksia koulun uskonnon opetuksesta ja uskonnon opettajista. Väestörekisterikeskuksen otantapalvelun avulla poimittiin 2000 vastaajaa käsittävä edustava otos iältään 1880 -vuotiaista suomalaisista eri puolilta maata. Otantamenetelmä oli ositettu otanta. Otannan ositteet olivat sukupuoli, ikä, asuinseutu ja kotipaikkakunnan koko. Ositteista poimittiin tilastoyksiköitä suhteellista kiintiöintiä käyttäen, jolloin eri-ikäisiä naisia ja miehiä, maalta ja kaupungeista oli otoksessa edustettuna siinä suhteessa kuin heitä oli perusjoukossa otoksen poimintahetkellä.

Täytetyn kyselylomakkeen palautti 588 henkilöä, joista naisia oli 364 (63 \%) ja miehiä 216 (37\%). Vastauksia palautui alle kolmannes (29.4 \%) lähetetyistä. Palautusprosentti ei ole kovin korkea, mutta vähän alle kolmannekseen jäävä osuus on hyvin tyypillinen postikyselyissä.

Taulukossa 1 vastaajajoukkoa tarkastellaan asuinseudun ja kristinuskoon suhtautumisen mukaan taulukoituna. Asuinalueissa pääkaupunkiseutu tarkoittaa Helsinkiä, Espoota, Vantaata ja Kauniaista. Etelä-Suomen, Länsi-Suomen sekä Itä-Suomen alueet viittaavat samannimisiin lääneihin ja Pohjois-Suomen alue kattaa Oulun ja Lapin läänit. 
Taulukko 1 Tutkimukseen osallistuneiden asuinseutu ja uskonnollisuus prosentteina; suluissa Suomen kansan väestöjakauma prosentteina ${ }^{1}$.

\begin{tabular}{l|c:c:c:c:c|c|c}
\hline & $\begin{array}{c}\text { usko- } \\
\text { vainen }\end{array}$ & $\begin{array}{c}\text { neutraali } \\
\text { hyväk- } \\
\text { syjä }\end{array}$ & $\begin{array}{c}\text { agnos- } \\
\text { tikko }\end{array}$ & $\begin{array}{c}\text { skep- } \\
\text { tikko }\end{array}$ & ateisti & yhteensä (\%) & N \\
\hline $\begin{array}{l}\text { pääkau- } \\
\text { punkiseutu }\end{array}$ & 8 & 49 & 19 & 8 & 16 & $15(18.7)$ & 88 \\
\hline Etelä-Suomi & 14 & 52 & 20 & 8 & 7 & $23(21.6)$ & 131 \\
\hline Länsi-Suomi & 21 & 48 & 13 & 9 & 8 & $33(35.3)$ & 189 \\
\hline Itä-Suomi & 26 & 44 & 17 & 8 & 5 & $15(11.3)$ & 87 \\
\hdashline $\begin{array}{l}\text { Pohjois- } \\
\text { Suomi }\end{array}$ & 17 & 50 & 18 & 10 & 4 & $14(12.4)$ & 76 \\
\hline yhteensä \% $\%$ & 18 & 49 & 17 & 8 & 8 & 100 & 5 \\
\hline
\end{tabular}

Muuttuja "uskonnollisuus" kuvaa, miten vastaajajoukko suhtautuu kristinuskoon. Jokainen vastaaja määritteli itse viidestä vastausvaihtoehdosta omaa käsitystään parhaiten vastaavan vaihtoehdon. Ne, jotka valitsivat vastausvaihtoehdon "luja uskon Jumalaan on koko elämäni perusta" muodostavat luokan uskovainen. Vaihtoehdon "uskon, että Jumala on olemassa" valinneet ovat neutraaleja hyväksyjiä, toisin sanoen he uskovat Jumalan olemassaoloon vailla sen suurempia intohimoja uskonasian puolesta tai sitä vastaan. Jos vastaaja on valinnut vastausvaihtoehdon "en tiedä uskonko Jumalaan", on häntä pidettävä agnostikkona, jolla ei ole Jumalasta tai todellisuuden perimmäisestä luonteesta tietoa. "Epäilen Jumalan olemassaoloa" on skeptikko ja vastaavasti "en usko Jumalaan" on ateisti.

Tutkimukseen osallistuneiden uskonnollisuutta on vaikea verrata koko väestöön, koska aivan vastaavalla tavalla kerättyjä tietoja suomalaisten uskonnollisuudesta ei ole. Näyttää kuitenkin siltä, että uskovaiset ovat yliedustettuina kun taas neutraalien hyväksyjien osuutta voi pitää liian pienenä. Agnostikkojen, skeptikkojen ja ateistien osuutta koko väestössä on vaikea arvioida, mutta ainakin uskontokuntiin kuulumattomien suomalaisten osuus on suurempi kuin ateistien osuus tässä tutkimuksessa. Osa agnostikoista (17\%) ja skeptikoista (21\%) on uskontokuntiin kuulumattomia.

Kyselyyn vastanneiden alueellisen edustavuuden selvittämiseksi on heidän lukumääräänsä verrattava Suomen väestön alueelliseen jakautumiseen. Vertailu osoittaa (taulukko 1), että pääkaupunkiseutu ja Länsi-Suomi ovat hieman aliedustettuja, toisin sanoen näiltä alueilta on tutkimukseen osallistunut vä-

Tiedot perustuvat vuoden 2002 väestötietoihin, jotka on poimittu Tilastokeskuksen verkkosivuilta osoitteesta http://pxweb2.stat.fi/Dialog/Saveshow.asp. 
hemmän väkeä kuin pitäisi. Itä-Suomi on kaikkein voimakkaimmin yliedustettu, mikä merkitsee siellä asuvien vastanneen kyselyyn enemmän kuin väestön suhteellinen osuus koko maan asukasmäärästä edellyttäisi. Myös Etelä- ja Pohjois-Suomi ovat lievästi yliedustettuja, mutta vähemmän kuin itäinen Suomi. Kaiken kaikkiaan otos vastaa verrattain hyvin koko maan väestön alueellista jakautumista. Voi tietenkin pohtia, miksi itäsuomalaiset ovat olleet erityisen halukkaita ilmaisemaan mielipiteensä uskonnon opetuksesta. Yksi syy lienee uskovaisten suuri määrä tässä ryhmässä. Vastaavasti pääkaupunkiseudun ateisteilla näyttää olleen tarve ilmaista näkemyksensä uskonnon opetuksesta vastaamalla kyselyyn.

Taulukko 2. Sukupuoli ja ikäryhmät; \% ja (N).

\begin{tabular}{l|c|c|c|c|c|c|c}
\hline & $\mathbf{1 8 - 3 0}$ & $\mathbf{3 1 - 4 0}$ & $\mathbf{4 1 - 5 0}$ & $\mathbf{5 1 - 6 0}$ & $\mathbf{6 1 - 7 0}$ & $\mathbf{7 1 - 8 0}$ & yhteensä \\
\hline Nainen & 23 & 14 & 18 & 25 & 13 & 6 & $100(357)$ \\
\hdashline Mies & 20 & 11 & 22 & 26 & 14 & 7 & $100(215)$ \\
\cline { 1 - 2 } & $22(126)$ & $13(74)$ & $20(114)$ & $25(144)$ & $13(76)$ & $6(38)$ & $100(572)$ \\
\hline
\end{tabular}

Taulukosta 2 käy selville, että nuoret aikuiset (18-30 -vuotiaat) osallistuivat ilahduttavan runsaasti tutkimukseen, vaikka heidän ikäisiään pidetään keskimäärin maallistuneempina ja kristinuskosta vieraantuneempina kuin vanhempia ikäluokkia (Niemelä 2003, 148-149). Ilmeisesti he halusivat ilmaista mielipiteensä kouluun ja uskontoon liittyvistä kysymyksistä, vaikka kirkkoon sitoutuminen on vähäistä. Edelleen taulukosta on luettavissa, että iäkkäimpien vastaajien (71-80 vuotta) osuus on pieni. Se kuitenkin vastaa erittäin hyvin tämän ikäryhmän osuutta Suomen väestöstä².

Tilastolliset analyysit suoritettiin SPSS -tilastomatemaattisella tietokoneohjelmalla. Analyysimenetelminä käytettiin regressioanalyysiä, faktorianalyysiä, yksisuuntaista varianssianalyysiä (ANOVA), monimuuttujaista varianssianalyysiä (MANOVA), ryhmittelyanalyysia (Cluster Analysis) sekä Khin-neliön ja korralaatiokertoimen merkitsevyyden testausta. Laajan analyysivalikoiman käyttöä voi perustella sillä, että näin saatiin selittävien ja selitettävien muuttujien asteikkojen, yhtä lailla kuin havaintojen määrän ja tutkittavan ilmiön mukaan oikeat menetelmät käyttöön.

2 Vuonna 2004 suomalaisten 70-79 -vuotiaiden osuus populaatiosta oli 7.32 prosenttia. Tieto on poimittu Tilastokeskuksen väestötietokannasta internet-osoitteesta: http://pxweb2.stat.fi/database/VaestoF6/VaestoF6rakenne/VaestoF6rakenne.asp. 


\section{Missä muodossa opetusta tulisi toteuttaa?}

Faktorianalyysia käyttäen vastaajien käsitykset uskonnon opetuksen toteuttamistavoista tiivistyivät neljään ulottuvuuteen. Faktoreista muodostettiin uskonnon opetuksen toteuttamismalleiksi kutsutut summamuuttujat. On huomattava, että seuraavaksi esiteltävät mallit eivät ole toisiaan poissulkevia. Yksi henkilö on voinut pitää kaikkia malleja tärkeinä ja toteuttamiskelpoisina tai torjua ne täysin. Niinpä tutkimuksen tulokset eivät suoraan vastaa kysymykseen, miten suomalaiset haluaisivat toteuttaa uskonnon opetuksen peruskoulussa. Sen sijaan voidaan tarkastella, miten tärkeänä erilaisia uskonnon opetuksen toteuttamismalleja pidettiin.

Uskonnon opetuksen totuttamismallien kannatusta tutkittiin paljon käytetyllä viisiportaisella Likert-tyyppisellä asenneasteikolla. Vastausvaihtoehto 1 tarkoitti "täysin eri mieltä", asteikon keskikohta (3) merkitsi, ettei vastaaja torju sen kummemmin kuin hyväksykään esitettyä väitettä. Asteikon toinen äärilaita (vastausvaihtoehto 5) merkitsi "täysin samaa mieltä".

Taulukko 3. Uskonnon opetuksen toteuttamista kuvaavien summamuuttujien keskiarvot, -hajonnat ja reliabiliteettikertoimet

\begin{tabular}{l|c:c:c}
\hline & $\boldsymbol{k a}$ & $\boldsymbol{s}$ & $\alpha$ \\
\hline Uskontotiedon opetus & 4.4 & .67 & .60 \\
\hline Kirkollis-kristillinen uskonnon opetus & 3.1 & .91 & .75 \\
\hline Vapaavalintainen uskonnon opetus & 2.7 & .94 & .82 \\
\hline Koulu ilman uskonnon opetusta & 1.7 & .91 & .88 \\
\hline
\end{tabular}

Tuloksen mukaan kouluopetus voi mieluiten olla objektiivisuuteen ja kaikkien uskontojen tasapuoliseen esittelemiseen pyrkivää uskontotiedon opetusta. Tällaista uskonnon opetusta suomalaiset kannattivat ylivoimaisesti eniten (ka $=4.4$ ). Sisällöllisesti opetukseen kuuluisi perustiedot maailmanuskonnoista ja lisäksi puolueetonta tietoa muista vakaumuksista. Koulun uskonnon opetus voi olla jossakin määrin kirkollis-kristillistä opetusta, jossa kristinusko ja kirkon tunnustus ovat opetuksen ensisijaiset tavoitealueet. Tällaista selkeän tunnustuksellista uskonnon opetusta ei torjuttu, eikä myöskään hyväksytty $(\mathrm{ka}=3.1)$. Vapaavalintainen opetus tekisi uskonnosta yhden valinnaisaineen, mikä ei saanut kansalaisilta kannatusta $(\mathrm{ka}=2.7)$. Vähiten kannatusta sai koulu, jossa ei olisi laisinkaan uskonnon opetusta $(\mathrm{ka}=1.7)$.

Suomalaisten käsityksiä uskonnon opetuksen toteuttamismallien kannatuksesta voidaan verrata muiden maiden uskonnon opetuskäytäntöihin. Ranskassa uskontoa ei opeteta laisinkaan yhteiskunnan ylläpitämissä kouluissa. Tällainen uskonnottoman koulun malli ei kiehdo suomalaisia. Myöskään eteläeurooppalainen - esimerkiksi katolisesta Italiasta tai ortodoksiselta Kyprokselta tuttu 
- malli, jossa opetetaan tunnustuksellisesti yhtä uskontoa, ei vastaa suomalaisten käsityksiä koulun katsomuskasvatuksesta. Ruotsissa opetetaan kaikille oppilaille yhteisenä oppiaineena tunnustuksetonta uskontotietoa. Se vastaa joiltakin osin suomalaisten näkemyksiä, mutta vain osittain. Suomalaiset eivät tahdo kaikille yhteistä uskonnon opetusta, vaikka kannattavatkin oppiaineen monikulttuurisuutta. Kokonaisuudessaan suomalaisten näkemykset vastaavat monessa kohdin maamme lainsäädäntöä ja koulun nykykäytäntöä, missä tavoitteena on perehtyä muihin uskontoihin, suomalaiseen katsomusperinteeseen ja omaan uskontoon. Kansalaisten käsitysten mukaan uskonnon opetus ei saisi olla liian kirkollista, mutta ei myöskään pelkästään erilaisten maailmankatsomusten esittelyä.

Vastaajien uskonnollisuus ja ikä selittivät uskonnon opetuksen toteuttamismallien kannatusta. Uskovaiset ja kristinuskoon neutraalisti suhtautuvat vastaajat suosivat eniten uskontotiedon opetusta, seuraavaksi eniten kirkolliskristillistä uskonnon opetusta. Vapaavalintainen opetus ei saanut tukea näiltä ryhmiltä ja koulu vailla uskonnon opetusta torjuttiin jyrkästi. Agnostikot ja skeptikot pitivät uskontotietoa tärkeimpänä. Heille vapaavalintainen opetus ja kirkollis-kristillinen uskonnon opetus olivat samanarvoisia, mutta uskonnon opetusta vailla oleva koulu torjuttiin molemmissa ryhmissä. Ateistit kannattivat erittäin voimakkaasti uskontotiedon opetusta ja melko voimakkaasti vapaavalintaista uskonnon opetusta. Heidän ryhmässään kirkollis-kristillinen opetus torjuttiin lievästi, samoin kuin koulu ilman uskonnon opetusta. Uskontotiedon opetuksen kannatus laski loivasti iän myötä. Kirkollis-kristillisen opetuksen kannatus vastaavasti nousi iän lisääntyessä.

Myös jotkin muut tekijät selittivät toteuttamistapojen kannatuksen vaihtelua. Vähiten koulutetut kannattivat voimakkaimmin kirkollis-kristillistä uskonnon opetusta, mitä kannattivat vähiten ylioppilaat. Koska vähiten koulutetut olivat iäkkäimpiä ja ylioppilaat nuorimpia, selittää ikä taustalla olevana muuttujana tulosta. Korkeakoulututkinnon suorittaneet olivat kriittisimpiä uskonnon opetusta kohtaan. Alueellisia eroja esiintyi siten, että suurimmissa kaupungeissa ei kannatettu kirkollis-kristillistä opetusta, mutta uskontotiedon opetusta pidettiin arvossa. Haja-asutusalueilla ja pikkukaupungeissa tilanne oli päinvastainen. Suurissa kaupungeissa pisimmälle edistynyt maallistuminen, pluralismi ja monikulttuurisuus selittävät tulosta.

\section{Millä perusteilla uskontoa voi opettaa?}

Uskontoa ei haluta poistaa koulun oppiaineitten joukosta. Kiinnostavaa onkin selvittää, miten uskonnon opetusta perustellaan. Syyt opettaa uskontoa voivat 
olla yksilöllisiä tai yhteisöllisiä ja molemmissa tapauksissa enemmän tai vähemmän uskonnollisia.

Kähkönen (1976) esitti ensimmäisen kerran kootusti eri lähtökohdista nousevat uskonnon opetuksen perustelut. Kasteopetusperustelun mukaan koulun uskonnon opetuksella on sama päämäärä kuin kirkon opetuksella. Näkemys oli vallitseva koulujärjestelmämme alkutaipaleella 1800-luvun lopulla ja vielä seuraavan vuosisadan alkupuolellakin. Nykyisellään niin koulun kuin kirkonkin puolella on jo kauan tunnustettu uskonnon opetus koulun omaksi toiminnaksi ja kirkon kasvatustyö siitä erilliseksi. Kulttuurihistoriallinen perustelu on tavallisimmin esitetty argumentti uskonnon opetuksen puolesta. Koulun kulttuuritehtävä on johdattaa oppilaat oman ympäristönsä kulttuurin tuntemiseen, omaksumiseen ja kehittämiseen. Suomessa kristinusko on kulttuurin olennainen osa, ja siksi se on opetuksen tärkein ja laajin sisältö. Antropologinen perustelu liittyy ihmiskäsitykseen, jonka mukaan jokainen ihminen on uskonnollinen. Uskonnollisuus on osa ihmisyyttä, ja uskontoon liittyvillä kysymyksillä on näin ollen tärkeä asema lapsen ja nuoren kokonaispersoonallisuuden osana. Näkemys uskonnon opetuksesta yksilönkehityksen ja identiteetin tukena kuuluu antropologisten perustelujen alueeseen. Antropologiset perustelut ovat tutut muualtakin kuin vain oman maamme rajojen sisäpuolelta. Esimerkiksi Euroopan saksankielisellä alueella painotettiin 1980- ja 1990-luvuilla voimakkaasti yksilön kehittymisen ja kypsymisen teemoja uskontokasvatuksessa. (Ks. Böhnke, Reich \& Ridez 1992; Oser 1988; Schweitzer 1991, 233-244.) Yhteiskunnallinen perustelu painottaa uskonnon opetusta kansalaiskasvatuksena, joka voi auttaa toimimaan asiallisesti yhteiskunnan jäsenenä. Yhteiskunnallinen perustelu on sopusoinnussa uskonnonvapauden positiivisen tulkinnan kanssa. Opetusta tuetaan niin kauan kuin kansan enemmistö ja tahto edellyttävät. Yhä monikulttuurisemmaksi muotoutuvassa yhteiskunnassa tämän perustelun merkitys korostuu entistäkin enemmän. Uskonnon opetuksen eettisissä perusteissa lähdetään siitä, että eettinen kasvatus on yksi olennainen uskonnon opetuksen tehtävä. Tästä syystä 1970-luvulla maamme peruskoulua toteutettaessa ei pidetty tarpeellisena luoda erillistä siveysopin eli etiikan opetusta, jota oli yritetty toteuttaa jo 1920-luvun alkupuolella.

Viimeaikaisessa suomalaisessa uskonnonpedagogisessa kirjoittelussa on tuotu esille viiden edellä esitetyn lisäksi joitakin muita perusteluja uskonnon opetuksen puolesta. Pruuki (2003) hahmottelee yleissivistyksellistä perustelua, joka tulee lähelle kulttuurihistoriallista ja antropologista perustelua, mutta on kuitenkin tarkoituksenmukaista erottaa omaksi kategoriakseen. Esimerkiksi voimassa olevassa opetussuunnitelmassa kaikkien uskontoaineiden yleistavoitteeksi asetetaan uskonnollisen ja katsomuksellisen yleissivistyksen antaminen. Kallioniemi $(2005,34)$ on muotoillut monikulttuurisuusperustelun. Sen perusajatuksen mukaan oppilaan on uskonnon opetuksessa mahdollista 
oppia tuntemaan eri ihmisten uskomuksia ja katsomuksia yli kulttuurirajojen sekä elämään dialogissa eriuskoisten ihmisten kanssa.

Tutkimuksessa käytetyssä kyselylomakkeessa oli 21 väittämää, joiden avulla selvitettiin uskonnon opetuksen perusteluja. Väittämistä muodostettiin edellä esitettyjen teoreettisten perusteiden nojalla summamuuttujia, jotta pystyttiin kuvailemaan, miten tärkeinä erilaisia perusteluja pidettiin. Taulukossa 4 on uskonnon opetuksen perusteluja käsitelleiden summamuuttujien keskiarvot suurimmasta alkaen, keskihajonnat ja Cronbachin alfa-kertoimet.

Taulukko 4. Uskonnon opetuksen perusteluja kuvaavien summamuuttujien keskiarvot suurimmasta pienimpään, keskihajonnat ja reliabiliteettikertoimet (arviointiasteikko: 1 $=$ ei lainkaan tärkeä $-5=$ erittäin tärkeä).

\begin{tabular}{l|c:c|c}
\hline & $\boldsymbol{k a}$ & $\boldsymbol{S}$ & $\alpha$ \\
\hline Kulttuurihistorialliset perustelut & 3.8 & .87 & .75 \\
Antropologiset perustelut & 3.6 & .91 & .84 \\
Yhteiskunnalliset perustelut & 3.5 & .78 & .70 \\
Eettiset perustelut & 3.5 & .92 & .82 \\
Kasteopetusperustelut & 3.3 & .96 & .70 \\
\hline
\end{tabular}

Suomalaiset pitivät kulttuurihistoriallisia tekijöitä tärkeimpinä perusteluina uskonnon opetukselle $(\mathrm{ka}=3.8)$. Kristinusko kuuluu suomalaiseen kulttuuriin, joten oppilaita on tärkeää johdattaa sen tuntemiseen. Lähes kaikissa uskonnon opetusta käsittelevissä lausunnoissa ja kannanotoissa kulttuurihistorialliset perustelut ovat olleet esillä. Antropologisiin eli ihmisolemuksesta ja -käsityksestä nouseviin perusteluihin suhtauduttiin myös myönteisesti $(\mathrm{ka}=3.6)$, joskin pidättyväisemmin kuin kulttuurihistoriallisiin perusteluihin. Suomalaiset hyväksyivät tietyin varauksin sen, että ihminen on uskonnollinen ja tarvitsee tukea maailmankatsomuksensa kehittymisessä. Yhteiskunnalliset ja eettiset perustelut saivat jonkin verran tukea kansalaisilta. Uskontokasvatuksella on jonkin verran kansalaisuuteen ja suomalaisuuteen niin kuin myös moraaliin liittyviä merkityksiä. Vähiten kannatusta saivat kasteopetusperustelut $(\mathrm{ka}=3.3)$, joiden mukaan kirkon ja koulun uskontokasvatus tähtäisivät samaan päämäärään.

Tuloksista päätellen uskonto kuuluu perustellusti koulun oppiaineitten joukkoon. Suomalaisten tulkinta uskonnonvapaudesta on positiivinen: oppilaille on taattava mahdollisuus oman vakaumuksen mukaiseen opetukseen. Tulosten mukaan oppilailla on oikeus saada tukea uskontokasvatuksen alueella yhtä hyvin kuin muillakin kasvatuksen osa-alueilla. Tuloksista myös huokuu suomalaisten usko koulun sivistävään tehtävään. Yksi yleissivistyksen mitta on riittävä osaamisen taso uskontoon liittyvissä asioissa.

Vastaajien oma uskonnollisuus selitti parhaiten uskonnon opetuksen perustelujen kannatusta. Ainoastaan yhteiskunnallisia perusteluja selitti, muista pe- 
rusteluista poiketen, eniten se, miten tarpeelliseksi uskonnon opetus oli koettu omana kouluaikana. Myös vastaajien koulutustaso selitti niukasti, mutta aina samansuuntaisesti opetusperusteluja: korkeasti koulutetut eivät hyväksyneet perusteluja niin voimakkaasti kuin vähän koulutetut. Tämä korostui erityisesti kasteopetukseen ja etiikkaan liittyvissä perusteluissa. Näyttää siltä, että koulutuksen lisääntyessä lisääntyvät koulun objektiivisuuteen liittyvät odotukset. Korkeasti koulutetut odottavat myös suurempaa tehokkuutta koulutukselta.

\section{Mielikuvat uskonnosta oppiaineena}

Ihmisillä on ikänsä, asenteidensa, elämänkokemustensa ja -tilanteittensa mukaan erilaisia käsityksiä siitä, mitä koulun uskonnon opetus on ja mitä sen tulisi olla. Vastaajia pyydettiin arvioimaan joitakin adjektiiveja ja käsitteitä, jotta saataisiin selville millaista he uskovat koulun uskonnon opetuksen nykyaikana olevan. Kuvioon 1 on koottu vastaajajoukon arviointien prosenttiosuudet.

Kuvio 1. Uskonto oppiaineena; \%-osuudet.

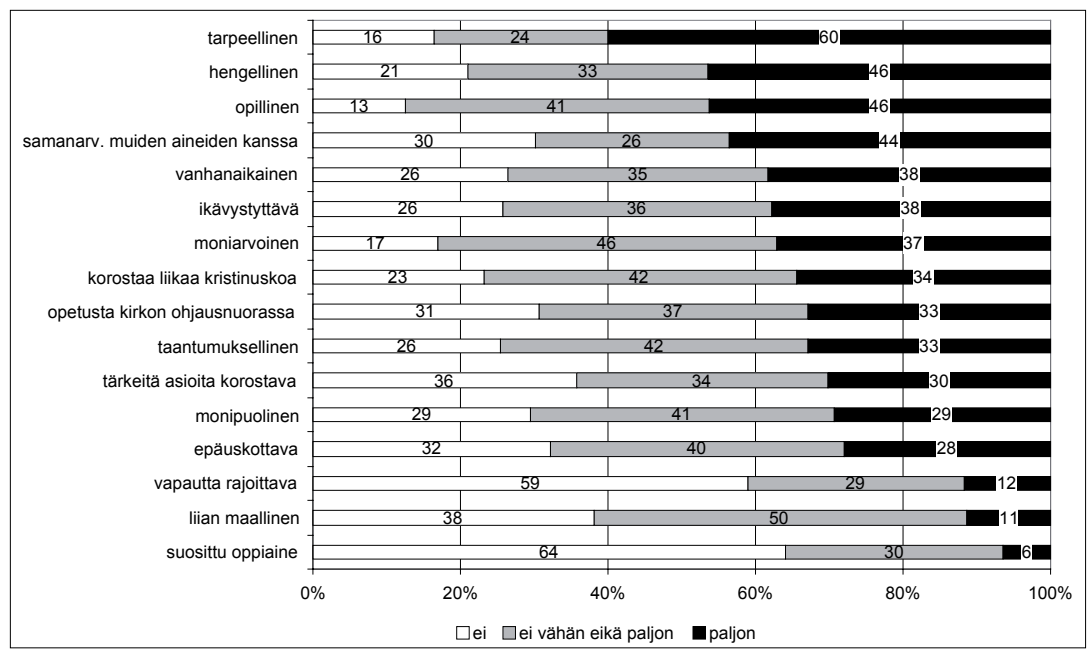

Uskonto on suomalaisten mielestä tarpeellinen oppiaine. Tässä muuttujassa myönteisten (paljon) käsitysten osuus oli suurin ja neutraalien käsitysten (ei vähän eikä paljon) osuus kaikista pienin. Vaikka uskonnon opetusta pidettiin tarpeellisena, sen arvioitiin olevan epäsuosittu kouluaine oppilaiden keskuudessa. Uskonnon opetukseen uskottiin olevan hengellistä luonteeltaan (46\% paljon). Dogmaattisuudesta oltiin kahta mieltä: 46 prosenttia vastaajista uskoi, 
että opillisuus leimaa paljon uskonnon opetusta, mutta 41 prosenttia vastaajista piti kouluopetusta opillisesti neutraalina. Muihin kouluaineisiin verrattuna uskonto jakoi mielipiteet. Vaikka 44 prosenttia vastaajista piti sitä samanarvoisena muiden aineiden kanssa, 30 prosenttia oli päinvastaista mieltä. Vanhanaikaisena ja ikävystyttävänä uskonnon opetusta piti 38 prosenttia vastaajista. Lähes yhtä suuri osuus (37\%) katsoi uskonnon opetuksen olevan moniarvoista, tosin tässä muuttujassa neutraalien osuus on melko suuri (46 \%).

Väittämiin, joissa käsiteltiin opetuksen kirkollisuutta ja kristillisyyttä suhtauduttiin enimmäkseen neutraalisti. Tosin kolmannes vastaajajoukosta (34 \%) arvioi, että opetus painottuu liikaa kristinuskoon, ja että uskonnon opetus on kirkon talutusnuorassa. Edelleen kolmannes näki uskonnon opetuksen olevan taantumuksellista. Tässä väittämässä neutraalien käsitysten osuus oli suuri (42 $\%)$.

Kuvion 1 perusteella muodostuu yleiskuva uskonnon opetuksesta varsin neutraalina oppiaineena. Siihen ei liity suuria intohimoja puolesta eikä vastaan. Kuvion harmaa alue osoittaa, ettei opetuksesta joko tiedetä tai sitten siihen asennoidutaan hyvin tasaisesti. Kuviosta voi nostaa esiin kolme seikkaa. (1) Uskonnon opetus nähdään tarpeelliseksi. Aikuisten mielikuvat eivät vastaa koululaisten parissa esiintyneitä käsityksiä, joiden mukaan uskonnon opiskelu olisi turhaa. (2) Uskonnon opetus ei rajoita vapautta. Uskonnonvapaus tulkitaan kansalaisten keskuudessa positiivisesti, vapautena oppia omaan uskontoon liittyviä asioita. (3) Uskonto ei ole suosittu oppiaine. Sysiharjun $(1970,32,41)$ mukaan keskikoulun päätösvaiheessa olevien oppilaiden mielestä uskonto oli useimmille yhdentekevä oppiaine (59\%), mutta ei suinkaan vastenmielisin, saa tulos jotenkin tukea tämän tutkimuksen tuloksista. Uskonto on tarpeellinen, mutta muuten neutraali oppiaine.

Omat kouluaikaiset kokemukset uskontotunneista selittivät voimakkaimmin mielikuvia oppiaineen luonteesta. Mitä positiivisemmat kokemukset, sitä mielenkiintoisempi, elämänläheisempi, ajankohtaisempi ja pohdiskelevampi aine uskonto vastaajien mielestä oli ja sen vähemmän ahdaskatseinen oppiaine. Tässä on varmasti pohdittavaa uskontokasvatuksen parissa työskenteleville. Kouluaikaiset kokemukset, muistot ja tuntien ilmapiiri vaikuttavat pitkään ja voimakkaasti oppiaineesta muodostuneisiin mielikuviin. Iän lisääntyessä mielikuvat uskonnon opetuksesta muuttuvat. Vanhempana uskonto nähdään syvällisempänä, ajankohtaisempana, mielenkiintoisempana ja elämänläheisempänä oppiaineena kuin nuorempana. Tulosta selittää ainakin se, että uskonnon merkitys lisääntyy yleensä iän myötä. 


\section{Uskonnon opetuksen tulevaisuus}

Tässä artikkelissa on tarkasteltu uskonnon opetuksen toteuttamistapoja, uskonnon opetuksen perusteluja ja mielikuvia tämän päivän koulun uskonnon opetuksesta. Tuloksista piirtyy kuva uskonnosta tarpeellisena, mutta ei erityisen suosittuna kouluaineena. Muiden kouluaineiden joukossa uskonnolla on paikkansa. Suomalaisten käsityksiin sopii nykyisten opetussuunnitelmien mukainen opetus, johon kuuluu ennen muuta oman uskonnon opiskelua, sitten tutustumista muihin uskontoihin ja maailmakatsomuksiin.

Miltä uskonnon opetuksen tulevaisuus näyttää? Tämän tutkimuksen tulosten perusteella opetuksen toteuttamismuodot ovat kohdallaan. Koulun uskonnon opetuksella on takanaan kansan tuki. Nyt on uskonnon opetuksen sisällöllisen kehittämisen aika. Tämän tutkimuksen tulokset osoittivat tärkeitä kehittämisalueita: uskonto voisi olla nykyistä mielenkiintoisempi ja ajankohtaisempi oppiaine. Sen suosiota voisi yrittää lisätä, varsinkin kun on oletettavissa, että valinnaisten kurssien määrä tulee lisääntymään. Mielikuvat uskonnon opetuksesta ovat monelta osin vanhentuneita.

Yhteistoiminnallisuuden lisääminen on yksi uskonnon opetuksen haaste tulevaisuudessa. Saksalainen uskonnonpedagogi Friedrich Schweitzer on puhunut voimakkaasti kooperatiivisen uskonnon opetuksen toteuttamisen puolesta. Schweitzerin ajattelutapa nousee hänen uskonnon opetusperusteistaan, joiden mukaan demokraattisen yhteiskunnan uskonnon opetuksessa oppilaan tulee tutustua sekä oman uskonnon sisäiseen että uskontojen väliseen dialogiin. Uskonnon opetuksen pitää perustua yksilön kunnioittamiseen, ja tällöin sen tulee tarjota mahdollisuuksia myös uskonnolliselle sitoutumiselle. Opetuksen neutraalisuus ei saa merkitä sitä, ettei olisi tilaa koululaisen oman tradition totuusväittämille ja niiden perusteella oman vakaumuksen muodostumiselle. (Schweitzer 2005, 10-11.)

Yhteistoiminnallinen uskonnon opetus, jota voi kutsua myös dialogiopetukseksi, sallii niin muiden uskontojen riippumattoman tarkastelemisen opetuksessa kuin myös oppilaan oman uskonnon opetuksen. Yhteistoiminnallisessa uskonnon opetuksessa työskennellään sekä erillisissä opetusryhmissä - joita opettaisivat oppilaan omaan kirkkokuntaan tai uskonnolliseen yhdyskuntaan kuuluvat opettajat - että yhteisissä ryhmissä dialogisessa ympäristössä. Dialogiryhmissä oppilaat kokoontuisivat yhteen oppimaan toinen toisiltaan keskinäistä ymmärtämystä ja toisten kunnioittamista. 


\section{Lähteet}

Böhnke, M., Reich, K. H. \& Ridez, L. (hrsg.) (1992). Erwachsen im Glauben.Beiträge zum Verhältnis von Entwicklungspsychologie und religiöser Erwachsenenbildung. Stuttgart: Kohlhammer.

Kallioniemi, A. (2005). Uskonnon opetus ja uskontokasvatus historiallis-yhteiskunnallisessa kontekstissa. Teoksessa Kallioniemi, A. \& Luodeslampi, J. (toim.), Uskonnon opetus uudella vuosituhannella, 11-49. Helsinki: Kirjapaja.

Kähkönen, E. (1976). Uskonnon opetuksen asema Suomen koulunuudistuksessa 1944 1970. Diss. Suomalaisen Teologisen Kirjallisuusseuran julkaisuja 101. Helsinki: STKS.

Niemelä, K. (2003). Suomalaisten uskonnollisuus uuden vuosituhannen alussa. Teoksessa Helander, E (toim.), Muutoksen tulkkina. Kirkot ja uskonnollinen elämä osana yhteiskuntaa, 140-154. Helsinki: Kirjapaja.

Oser, F. (1988). Wieviel Religion braucht der Mensch? Erziehung und Entwicklung zur religiösen Autonomie. Güttersloh (Germany): Verlagshaus Gerd Mohr.

Pruuki, L. (2003). Uskonnon opetuksen asema ja luonne suomalaisessa koulujärjestelmässä. Lectio Praecursoria 10.1.2003. http:/www.janua.helsinki.fi/uskonnonpedagogiikka/pruuki_vaitos.html, luettu 7.12.2006.

Salonen, A. (1995). Peruskoululaisten käsityksiä koulusta ja elämästä. Opetushallituksen moniste 12/1995. Helsinki: Painatuskeskus.

Schweitzer, F. (1991). Lebensgeschichte und Religion. Religiöse Entwicklung und Erziehung im Kindes- und Jugendalter. München: Chr.Kaiser.

Schweitzer, F. (2005). Children's Right to Religion: A Challenge to Educational Neutrality? http://www.edu.joensuu.fi/ortoweb/SchweitzerTartu.pdf, luettu 11.1. 2006.

Seppo, S. (1971). Abiturienttien asenteet uskonnon opetukseen. Diss. Jyväskylä Studies in Education, Psychology and Social Research 25. Jyväskylä: Jyväskylän yliopistoyhdistys.

Sysiharju, A-L. (1970). Mieluisa-yhdentekevä-vastenmielinen. Eri oppiaineiden oppilaissa herättämistä tunnereaktioista 1960-luvun keskikoulun päätösvaiheessa. Helsingin yliopiston kasvatustieteen laitoksen tutkimuksia N:o 8. Helsinki. 



\title{
Evankelisluterilaisen uskonnon opettajat ja uskonnon opetuksen tulevaisuus monikulttuuristuvassa yhteiskunnassa
}

\author{
Liisa Odiah
}

Tiivistelmä

Artikkeli pohjautuu vuonna 2003 valmistuneeseen pro gradu-tutkielmaan, jossa käsiteltiin uskonnon opetusta ja monikulttuurisuutta uskononnopettajien näkökulmasta. Tutkielmaa varten haasteteltiin 12 pääkaupunkiseudun peruskoulun yläluokkien ja lukion evankelisluterilaisen uskonnon aineenopettajaa. Aineiston keruumenetelmänä käytettiin teemahaastettelua. Tutkimusotteena toimi fenomenografia, jossa tutkimustuloksia ovat käsityksien sisältöihin sidotut kategoriat. Tutkielman yhtenä keskeisenä lähtökohtana oli tarkastella uskonnon opetuksen kehittämistarpeita suhteessa monikulttuuristumiseen. Tutkielmasta kävi ilmi, että uskonnon opettajat tiedostavat selvästi uskonnon opetuksen merkittävän roolin monikulttuurisen yhteiskunnan rakentamisessa. Uskonnon opettajat ovat pohtineet uskonnon opetuksen tulevaisuutta monista eri näkökulmista. Artikkelissa esitellään uskonnon opettajien käsityksiä uskonnon opetuksen haasteista ja tulevaisuuden skenaarioista. Aineistosta muodostetut kahdeksan kategoriaa on jaettu kolmeen ylemmän tason kategoriaan: nykyisen järjestämismallin säilyttämistä kannattaviin ja kaikille yhteistä katsomusainetta ajaviin käsityksiin sekä sisältöjen kehittämiseen keskittyvään käsitykseen. Artikkelissa esitellyt kategoriat kuvaavat monipuolisesti uskonnon opetuksen kehittämistarpeita monikulttuuristuvassa yhteiskunnassa.

Avainsanat: monikulttuurisuus, monikulttuurisuuskasvatus, uskonnon opetus, uskonnon opettajat

\section{Monikulttuuristuva yhteiskunta}

Suomalainen yhteiskunta on muuttunut viime vuosikymmeninä entistä monikulttuurisemmaksi. Tämä tarkoittaa sitä, että yhteiskuntaan kuuluu yhä useampia eri kulttuureja edustavia ihmisiä. Suomessa on ollut aina vähemmistökulttuurin asemassa olevia ryhmiä, joita ovat esimerkiksi saamelaiset ja romanit. Monikulttuuristuminen on kuitenkin ymmärretty Suomessa lähinnä 
1990-luvulta alkaneen voimakkaamman maahanmuuton seuraukseksi. (Liebkind 2000, 171.)

Suomea on vaikea pitää monikulttuurisena, mikäli sitä verrataan muihin aidosti monikulttuurisiin maihin, kuten Iso-Britanniaan, Ranskaan tai Saksaan. Suomeen tulleista maahanmuuttajista lähes puolet asuu pääkaupunkiseudulla: Esimerkiksi vuonna 2001 Suomessa oli lähes 100000 ulkomaalaista, joista hieman yli 28000 asui pelkästään Helsingissä. Myös Espoossa ja Vantaalla ulkomaalaisia oli suhteellisesti enemmän kuin muualla Suomessa. Monikulttuuristuminen onkin ollut voimakkainta juuri pääkaupunkiseudulla. Suurimpia maahanmuuttajaryhmiä vuonna 2001 olivat Venäjältä, Virosta, Ruotsista, Somaliasta ja entisen Jugoslavian alueelta tulleet ryhmät. (Tilastokeskus 2002.)

Myös Suomen uskonnollinen tilanne on muuttunut entistä moninaisemmaksi monikulttuuristumisen myötä. Uusia uskonnollisia liikkeitä on syntynyt runsaasti, ja ennen hyvin pieniä kannattajamääriä sisältäneet uskontokunnat ovat voimistuneet. Esimerkiksi islamin merkitys on kasvanut viime vuosina voimakkaasti. Arviot maassa asuvan muslimiväestön määrästä vaihtelevat noin 10000 ja 25000 välillä. (Heino 1997, 22-23; Kääriäinen et. al 2003, 48.)

\section{Katsomusopetuksen oppiainetraditio ja monikulttuuristuminen}

Suomalaisen katsomusopetuksen järjestämismalli määriteltiin juridisesti 1920-luvulla. Vuoden 1922 uskonnonvapauslaki määräsi, ettei uskonnon opetus saanut olla ristiriidassa kotien uskonnon opetuksen kanssa. Jos kouluissa annettaisiin uskonnon opetusta jonkin tunnustuskunnan mukaan, tulisi toisiin tunnustuskuntiin kuuluvat vapauttaa opetuksesta vanhempien niin vaatiessa. Vuoden 1923 kansakoululaissa määrättiin, että kouluissa tuli opettaa uskontoa sen uskontokunnan tunnustuksen mukaan, johon oppilaiden enemmistö kuului. Uskonnon opetus määräytyi näin tunnustukselliseksi eli uskontokuntasidonnaiseksi opetukseksi. Laki määräsi lisäksi, että jos koulussa oli vähintään 20 enemmistön uskontokuntaan kuulumatonta oppilasta, heille tuli vanhempien vaatimuksesta opettaa oman uskontokunnan mukaista uskontoa. Jos he eivät kuuluneet mihinkään uskontokuntaan, heille tuli opettaa tunnustuksetonta uskontojen historiaa ja siveysoppia. (Laki 137/1923; Pyysiäinen 1982, 22-24; Saine 2000, 73-75; Uskonnonvapauslaki 267/1922, §8.)

Oppikouluissa uskonnon opetuksen asema ja luonne määräytyivät vielä pitkään vuoden 1872 koulujärjestyksen mukaisesti. Sen mukaan uskonnon opetuksen oli oltava evankelisluterilaisen opin mukaista ja jotakin toista uskontoa tunnustavat tuli vapauttaa kokonaan uskonnon opetuksesta. Vähemmistöistä vain ortodokseille tarjottiin omaa uskonnon opetusta. Muutos tuli lukioihin 
vasta vuonna 1985, kun elämänkatsomustiedosta tuli uskonnottomille tarkoitettu oppiaine ja kansakoululain periaatteet siirtyivät koskemaan myös lukiota. (Pyysiäinen 1998, 45; Saine 2000, 185-188.)

1920-luvulla tehdyt juridiset perusratkaisut ovat pääpiirteissään voimassa vielä tänäkin päivänä. Niihin on tehty vain pieniä muutoksia. Uskonnollisten vähemmistöjen saaman opetuksen ja mihinkään uskontokuntaan kuulumattomille järjestettävän opetuksen minimiraja on laskettu kolmeen oppilaseen ja uskontojen historia ja siveysoppi on muuttunut elämänkatsomustiedoksi. (Pyysiäinen 1998, 45.) Lisäksi ilmaus tunnustuksen mukainen uskonnon opetus on korvattu ilmauksella oppilaan oman uskonnon opetus. (Uskonnonvapauslaki 453/2003, 6§; Perusopetuslaki 454/2003, 13§; Lukiolaki 455/2003, 9§.) Suomessa eri uskonto- ja katsomusryhmiin kuuluvat oppilaat opiskelevat joko omaa uskontoa tai elämänkatsomustietoa omissa erillisissä ryhmissään.

Uskonnon opetuksen järjestämismalli on herättänyt vilkasta keskustelua viime vuosina, jolloin myös monikulttuuristumiskehitys on ollut voimakkainta. Vuoden 2003 uskonnonvapauslain valmistelun ja käsittelyn yhteydessä pohdittiin näkyvästi uskonnon opetuksen tehtäviä ja tulevaisuutta. Keskustelussa pohdittiin muun muassa, miten monikulttuurisessa yhteiskunnassa tarvittavaa suvaitsevaisuutta ja uskontojen välistä vuoropuhelua voidaan edistää nykyisen mallin puitteissa, jossa eri uskonto- ja katsomusryhmät erotetaan toisistaan. Nykyisen mallin tilalle ehdotettiin kaikille yhteistä katsomusainetta. (ks. esim. Eduskunnan keskustelu hallituksen esityksen 170/2002 pohjalta 2002; Helsingin Sanomat 2003.) Tällainen malli on käytössä esimerkiksi Ruotissa, jossa kaikille oppilaille opetetaan uskontotieto-nimistä (religionskunskap) oppiainetta.

Koulun oppiaineena uskonto on pyrkinyt sisältöjen osalta vastaamaan monikulttuuristumisen synnyttämiin haasteisiin. 1970-luvulta lähtien vieraat uskonnot ovat tulleet osaksi uskonnon opetuksen opetussuunnitelmia. (Iisalo 1970, 85-86; Mauranen 1982, 144.) Muutos on näkynyt myös uskonnon opetuksen oppikirjoissa (Autio 2001). Maailmanuskontoja käsittelevä aines on tullut uskonnon opetuksessa koko ajan keskeisemmäksi. Näin oppiaineen sisältö on ollut jatkuvasti vuorovaikutuksessa yhteiskunnassa tapahtuvien muutosten kanssa.

\section{Uskonnon opettajien käsityksiä uskonnon opetuksen tulevaisuudesta}

Yhteiskunnalliset ilmiöt heijastuvat aina kouluun. Oppiminen on sosiaalinen prosessi, jossa oppilas saa vaikutteita ympäröivän yhteisön käsityksistä ja muodostaa maailmankuvansa yhteiskunnallisten vaikutteiden avulla. Koulut 
ovatkin aikamme pääsymboleja, joissa yhteiskunnan muutokset näkyvät ja kuuluvat. Monet näistä muutoksista sekä niistä aiheutuvat haasteet voidaan tunnistaa parhaiten juuri opettajan päivittäisessä työssä. (Ks. Hargreaves 1994.) Uskonnon opettajien tehtävä on antaa oppilaille monipuolisia valmiuksia uskonnollisen ja katsomuksellisen ajattelun ymmärtämiseen. Tämä tehtävä pitää kuitenkin suhteuttaa aina oppilaiden elämäntodellisuuteen sekä yhteiskunnallisista ja kulttuurisista muutoksista johtuviin uusiin korostuksiin.

Kasvatus on pedagogisessa mielessä vuorovaikutuksellinen prosessi. Opettajat joutuvat miettimään työssään sen monimutkaisia kysymyksiä. Siksi on tärkeää selvittää heidän käsityksiään opetukseen liittyvistä kysymyksistä. (Kansanen ja muut 2000, 89). Opettajien käsitykset ovat tärkeä tutkimuskohde myös vallitsevan opetussuunnitelmaideologian valossa. Siinä opetussuunnitelma nähdään alati kehityksessä ja muutoksessa olevaksi prosessiksi, joka on jatkuvasti vuorovaikutuksessa ympäristön kanssa. Opettajan tehtävänä ei ole enää opetussuunnitelman täsmällinen toteuttaminen, vaan opetussuunnitelman aktiivinen suunnitteleminen ja oman työnsä jatkuva kehittäminen. (Ks. esim. Kallioniemi 1994, 34-36.)

Vuonna 2003 valmistuneessa pro gradu -tutkielmassani tarkastelin pääkaupunkiseudun uskonnon pettajien käsityksiä uskonnon opetuksesta ja monikulttuurisuudesta. Yhtenä tutkimuksen keskeisenä lähtökohtana oli tarkastella uskonnon opetuksen kehittämistarpeita suhteessa monikulttuuristumiseen. Tehtävänä oli tutkia, miten ja missä määrin uskonnon opetusta pitäisi opettajien mukaan kehittää vastatakseen monikulttuurisuuden synnyttämiin haasteisiin. Aineiston keruumenetelmänä oli teemahaastattelu ja tutkimusotteena fenomenografia. Tutkimukseen osallistui 12 pääkaupunkiseudun peruskoulun yläluokkien ja lukion evankelisluterilaisen uskonnon aineenopettajaa. Fenomenografisen tutkimuksen tarkoituksena on löytää käsityksien sisältöön sidottuja kategorioita. Nämä kategoriat ovat fenomenografisen tutkimuksen tuloksia. (Larsson 1986, 21-23.)

Muodostin aineistosta kahdeksan kategoriaa koskien uskonnon opettajien käsityksiä uskonnon opetuksen kehittämisestä. Jaoin käsityskategoriat kolmeen ylemmän tason kategoriaan: nykyisen järjestämismallin säilyttämistä kannattaviin, kaikille yhteistä katsomusainetta ajaviin käsityksiin ja sisältöjen kehittämiseen keskittyvään käsitykseen. Käsityskategoriat on esitelty taulukossa 1. 
Taulukko 1. Käsitykset uskonnon opetuksen kehittämisestä

\begin{tabular}{|c|c|}
\hline \multirow{3}{*}{$\begin{array}{l}\text { Nykyisen järjestämismallin } \\
\text { säilyttäminen }\end{array}$} & Uskonnonvapauden periaatteita tukeva malli \\
\hline & Oppilaiden identiteetin kehittymistä tukeva malli \\
\hline & Laaja-alaista uskonnon opetusta tukeva malli \\
\hline \multirow{4}{*}{$\begin{array}{l}\text { Kohti kaikille yhteistä } \\
\text { katsomusopetusta }\end{array}$} & Resursseihin ja organisointiin liittyvät kehittämispaineet \\
\hline & Kontaktit lisäävät suvaitsevaisuutta \\
\hline & Uskonnollinen ja katsomuksellinen yleissivistys kaikille \\
\hline & Katsomusaineiden osittainen yhdistyminen \\
\hline $\begin{array}{l}\text { Sisältöjen kehittäminen } \\
\text { (riippumatta katsomusopetuksen } \\
\text { järjestämismallista) }\end{array}$ & Uskontotieteellisen aineksen vahvistaminen \\
\hline
\end{tabular}

\section{Käsitykset, joissa nykyinen malli halutaan säilyttää}

Ensimmäisessä ylemmän tason kategoriassa katsomusopetus haluttiin säilyttää nykyisenkaltaisena oman uskonnon mukaan määräytyvänä opetuksena. Ensimmäisessä alemman tason kategoriassa uskonnon opetusta tarkasteltiin uskonnonvapauden näkökulmasta. Opettajat käsittivät nykyisen katsomusopetuksen järjestämismallin tukevan parhaiten kansalaisten uskonnonvapautta. Erityisesti uskonnollisilla vähemmistöillä katsottiin olevan nykyisessä mallissa parhaimmat edellytykset säilyttää oma identiteettinsä ja katsomuksensa.

Opettajien mukaan nykyisen järjestämismallin mukainen uskonnon opetus kuitenkin edellyttää, että oppilaat saavat riittävästi tietoa muista uskonnoista. Opetuksen tulee siis olla monipuolista kaikille katsomusopetusryhmille. Opettajat näyttivät toivovan, että myös muiden uskontojen antamassa opetuksessa käsiteltäisiin enemmän erityisesti valtaväestön luterilaisuutta.

Opettajat käsittivät uskonnon opetuksen olevan aine, joka herättää voimakkaita tunteita. Vaikka osalla ei olluti mitään kaikille yhteistä katsomusainetta vastaan, he eivät yksinkertaisesti uskoneet sillä olevan realistisia mahdollisuuksia toteutua. Kaikille yhteisen katsomusaineen ongelmiksi muodostuisivat kysymykset opettajien pätevyydestä, ryhmien luottamuksesta opettajaa kohtaan ja oppiaineen sisällöistä. Erityisesti vähemmistöjen uskottiin pitävän tiukasti kiinni nykyisenkaltaisesta katsomusopetuksen järjestämismallista.

H8: Uskonto on niin asenteisiin ja tunteisiin sidottu, että siinä on kyse luottamuksesta, että luotetaanko me, voinko mää luottaa, että mun lapseni saa mahdollisimman hyvää uskonnon opetusta tai tietoa keneltä tahansa, kuka tahansa sitä opettaa, 
että musta se [kaikille yhteinen katsomusaine] on ongelma. Ei se musta yksinkertainen asia oo.

Osa opettajista näki kaikille yhteisen katsomusaineen olevan luterilaisen ajatusmaailman tuote. Luterilaisessa perinteessä on luontevaa tehdä ero maallisen ja uskonnollisen regimentin (tässä tapauksessa kirkon ja koulun) välillä. Muissa uskontoryhmissä uskonnollisen ja maallisen välistä eroa ei olla välttämättä totuttu tekemään samassa määrin. Erityisen hyvin tämä näkyy opettajien mielestä etiikan opetuksessa. Jaana Hallamaa $(1998,99,101)$ on käsitellyt artikkelissaan etiikan kytköstä arvoihin ja arvoja koskeviin sitoumuksiin. Etiikka ei voi koskaan olla neutraalia, sillä jo etiikan kysymyksenasettelut ja näkökulman valinta riippuvat omaksutuista arvoista. Luterilaisessa perinteessä etiikka ja moraali on nähty ennen muuta järjen asioiksi. Etiikan opettaminen oppilaiden omaan uskontoon sidotun uskonnon opetuksen osana on reilua, koska tällöin jo opetuksen lähtökohdat paljastavat, että ollaan tekemisissä arvojen ja arvoja koskevien sitoumusten kanssa. Tämänkin pohjalta nykyinen malli tukee opettajien mukaan parhaiten uskonnonvapauden periaatteita monikulttuurisessa yhteiskunnassa.

H10: Luterilaisesta näkökulmasta se on vähän että, ainakin mun käsittääkseni, erillistä kristillistä etiikkaa ei ainakaan sisällöllisesti oo olemassa. Tietysti ne perustelut ja motivaatiot, niin niitä ei niin hanakasti [kaikille yhteisessä katsomusopetuksessa] käsiteltäis uskontopohjaisina. Etiikan sisällöistä voitais hyvinkin päästä yhteisymmärrykseen, mutta se miten uskonto ja etiikka liittyy yhteen ja se oma perinne, niin siitä mää en oliskaan niin varma. [...] Puhumattakaan sitten kun mennään islamin puolelle, niin sillon joskus tulee kyse siitä, ettei välttämättä ymmärretä lainkaan tämmöistä ajattelua, et koulun tehtävä on enemmän tämmöinen yleissivistävä ja tiedollinen ja siellä myös uskonnon opetuksen tehtävät. Uskonnon harjoittaminen erikseen suomalaisessa luterilaisessa kahden regimentin maaperässä on aika selvää. Muslimille, joka tulee tänne, myös islamin opettajalle, se tuntuu aika oudolta ajatukselta, että on niinku erikseen yhteiskunta ja sitten on tää uskonto ja yhteiskunnan tehtävä on opettaa tietoa uskonnosta, uskonnon opetus olis enemmän tämmöistä tiedollista, niin mää ymmärrän että se voi kuulostaa muusta kuin luterilaisesta aika oudolta.

Toisessa alemman tason kategoriassa nykyisen katsomusopetuksen järjestämismallin katsottiin tukevan parhaiten uskonnon opetuksen tehtävää tukea oppilaiden kulttuuri-identiteetin ja elämänkatsomuksen muotoutumista. Nämä tehtävät nähtiin tärkeiksi monikulttuurisuuden näkökulmasta, koska vain nuoren, jolla on hyvä itsetunto ja itsetuntemus, katsottiin pärjäävän monikulttuurisessa yhteiskunnassa. Opettajat kokivat, että tietopainotteisessa, kaikille yhteisessä katsomusaineessa näiden tavoitteiden toteutuminen olisi mahdotonta, koska ne edellyttävät mahdollisuutta pohtia omaa uskontoa ja eri uskontoja 
myös tunnetasolla. Uskonnollista kysymyksenasettelua ja pohdintaa haluttiin pitää esillä uskonnon tunneilla, joskaan omaa uskontoa ei pyritty tuputtamaan oppilaille. Opettajat kokivat, että nykyisessä mallissa omaa uskontoa pystyttiin pitämään esillä tiedollisesti ja sisällöllisesti korostetummin, mikä katsottiin kulttuuri-identiteetin kehittymisen kannalta hyväksi asiaksi.

H2: Mää ymmärrän sen pointsin siinä [kaikille yhteisessä katsomusaineessa], mutta siinä on kuitenkin tietynlainen näköharha. Mun mielestä se veis tän homman ihan väärään suuntaan, että se veis yhä enemmän sinne pään tasolle, yhä kauemmas pois sydämestä, koska uskonnon ydin on sydän. Uskonnon ydin on usko, ei sitä voi erottaa uskonnosta, vaikka uskonto ja usko on ihan eri asioita, en mää mikään pappi täällä oo. Kuitenkin jos mun pitäis puhua uskonnosta ilman, että mä mainitsisin sanoja Jumala tai Jeesus, ilman että joku virkamies sanois, että teit virkavirheen, ei siitä tulis mitään.

H10: [Nykyisen järjestämismallin] arvo on siinä, että ainakin pystyy keskittymään ja korostamaan sitä omaa identiteettiä myös tiedollisesti. [Kaikille yhteisessä katsomusaineessa ongelmana olisi] ehkä juuri se, että omalle perinteelle olennaisia asioita, noin ihan tiedollisestikaan, ei pystyttäis keskittymään niin montaa tuntia kuin nykyisin, eli se tieto jäis kuitenkin pinnallisemmaksi. Jos nyt on tarkoitus siirtää kulttuuria silleen sisäistyneesti, niin se vaatii tietyn paneutumisen.

Kolmannessa alemman tason kategoriassa opettajat näkivät nykyisen mallin tukevan parhaiten laaja-alaista uskonnon opetusta. Oman uskonnon mukaan määräytyvässä opetuksessa voidaan opiskella ainakin yksi eli oma uskonto perusteellisesti. Opettajien mukaan oppilaiden ei ole tänä päivänä ylipäätään helppoa ymmärtää uskonnon (minkä tahansa) merkitystä yksilön elämässä. Tätä ymmärrystä pidettiin erityisen tärkeänä valmiutena yhteiskunnassa, jossa on yhä enemmän eri uskontoihin ja kulttuureihin kuuluvia ihmisiä.

Uskontoa pidettiin vaikeana opetusaineena aineen abstraktin luonteen vuoksi. Opettajat kokivat, että uskonnon pitäminen esillä samalla tavalla konkreettisesti, kuin he nyt saivat tehdä, olisi vaikeaa kaikille yhteisessä katsomusaineessa. Käsityskategoriassa ilmeni pelko siitä, että kaikille yhteinen katsomusaine veisi opetuksen tilanteeseen, jossa uskontoja ei enää uskallettaisi käsitellä avoimessa ilmapiirissä, jotta ei loukattaisi toisella tavalla uskovaa luokkatoveria. Opettajien mukaan nykyisen mallin puitteissa uskontoja pystytään käsittelemään monipuolisesti eri näkökulmista. Pelkona tuntui olevan sirpalemainen ja pinnallisesti eri uskontoja esittelevä kaikille yhteinen katsomusaine.

Haastattelija: Mikä tässä nykyisessä järjestelmässä on sitten se hyvä puoli?

H3: Se on se, että mää saan kuitenkin aidosti pitää uskonnon tässä esillä koko ajan ja opettaa niille, mikä on uskonnollista. Tiäksää, että pelkästään sen eron opet- 
taminen, että mikä on tieteellistä ja mikä uskonnollista ei ole ollenkaan helppoa. Se tulisi varmasti vaikeammaksi opettaa, jos olis vaan yleinen uskontotieteellinen lähestymistapa. [...] Mää oon sanonutkin, että miettikää nyt vähän kuinka helppoa on köksän maikalla, kun se ottaa esineen ja sanoo, tämä on kattila. Mutta kun mun pitää opettaa vaikka synti taikka armo, niin mää en voi tuoda sitä tänne näytille.

Osa opettajista pelkäsi, että kaikille yhteinen katsomusaine alkaisi kehittyä kohti yleiseettistä ainetta, jossa uskontojen ja katsomusten opiskelu jäisi vähitellen sivuseikaksi. Uskonnon opetusta ei haluttu redusoida pelkäksi arvokasvatukseksi. Puolustaessaan nykyistä uskonnon opetuksen järjestämismallia opettajat kokivat puolustavansa samalla uskonnon opetuksen laaja-alaisuutta sekä eri uskontoja ja katsomuksia käsittelevää oppiainesta. Kun uskonnon opetuksesta ja sen merkityksestä on keskusteltu monikulttuuristuvassa Euroopassa, uskonnon opetuksen eettinen anti on nostettu usein tärkeimmäksi aineen olemassaoloa puolustavaksi perusteluksi (esim. Heimbock ja muut 2001, 12). Myös muun muassa Tirrin $(1995,20-23)$ ja Kallioniemen $(1997,144) \mathrm{mu}-$ kaan Suomessa, varsinkin 1990-luvun keskusteluissa, korostettiin näkemystä uskonnon opetuksesta eettisenä opetuksena ja arvokasvatuksena.

H10: Mä pelkään sitä, että se [kaikille yhteinen katsomusopetus] jää niinku tiedollisesti liian pinnalliseksi semmoisessa ryhmässä. Ja sitten aina kun puhutaan uskonnon opetuksesta ja sen tehtävästä, niin kauheen helposti sille kaadetaan niinku semmoinen arvokasvatuksen ja eettisen kasvatuksen koko lasti. Ihan niinku se olis näiden katsomusaineiden, eli elämänkatsomustiedon ja uskonnon homma. Nyt mä pelkään esimerkiksi sitä, että tuommoiseen sitten vielä ajateltais, että kun ei ole olemassa semmoista ihan yhteistä taustaperäistä pohjaa, se ratkaistaiskin helposti sitten sillä, että otettaiski sitten tämmöistä eettistä ainesta sinne ja uskonto ilmiönä tyhjentyy jotenkin liikaa, vielä nykyistä enemmän etiikkaan. Eli ohitetaankin ne muut uskonnolliset kysymykset ku nää eettiset kysymykset. Ja sen näkee monissa puheenvuoroissa, kun uskonnon opetuksesta puhutaan, niin ne lähtee jotenkin semmoisesta, että ei tää uskonto ilmiönä ookkaan ihan se keskeisin, ja oma uskonto.

\section{Käsitykset, joissa kannatetaan kaikille yhteistä katsomusopetusta}

Toisessa ylemmän tason kategoriassa uskonnon opetuksen nähtiin kehittyvän kohti kaikille uskonto- ja katsomusryhmille yhteistä katsomusopetusta tai osittain yhteistä katsomusopetusta. Uuden uskonnonvapauslain esityksen yhteydessä käydyssä keskustelussa esiinnoussut uskontotieto-niminen aine viittasi lähinnä Ruotsissa annettavaan katsomusopetukseen (ks. esim. Eduskunnan keskustelu hallituksen esityksen 170/2002; Helsingin Sanomat 2003). Tällai- 
nen niin kutsuttu tunnustukseton tai objektiivinen uskonnon opetus pyrkii antamaan informaatiota eri uskonnoista ja katsomuksista. Vaikka mitään uskontoa ei aseteta tässä mallissa erityisasemaan, luterilaisuutta käsitellään kuitenkin suhteessa enemmän niin kutsutun kotiseutuperiaatteen mukaisesti. (Pyysiäinen 1982, 54-55; Skeie 2001, 243-245.) Kotiseutuperiaatteen mukaan opetus painottuu siihen uskonnolliseen, katsomukselliseen ja kulttuuriseen pohjaan, jonka keskellä oppilaat ovat kasvaneet (Kähkönen 1976, 244-245). Opettajat tarkoittivat kaikille yhteisellä katsomusopetuksella julkisessa keskustelussa esiintynyttä, Ruotsissa annettavan uskontotiedon kaltaista ainetta, jossa opetus painottuisi kuitenkin hieman muita uskontoja ja katsomuksia enemmän luterilaisuuteen.

Ensimmäisessä alemman tason kategoriassa katsottiin, että monikulttuuristumisen myötä nykyisen järjestämismallin ylläpitäminen tulee yksinkertaisesti mahdottomaksi johtuen taloudellisista ja hallinnollisista syistä. Myös Hanna Linnan (2001, 62-83; 90-91) pro gradu -tutkielmassa lukion opettajat ja erityisesti rehtorit toivoivat kaikille yhteistä katsomusainetta resurssi- ja työjärjestyksellisistä syistä. Kun yhteiskunnassa on yhä enemmän ryhmiä, jotka saavat oman uskontonsa opetusta muodostuu katsomusopetus ensinnäkin hyvin kalliiksi kouluille. Opettajat myös ihmettelevät, miksi esimerkiksi ortodokseille, luterilaisille ja elämänkatsomustietoa käyville oppilaille pitää järjestää kullekin erikseen maailman uskontojen kurssi, kun kurssien sisällöt eivät juuri eroa toisistaan. Opettajat pitävätkin nykyistä järjestelmää tältä osin resurssien tuhlauksena.

Monen eri uskonto- ja katsomusryhmän mahduttaminen koulun työpäivään on lukujärjestysteknisesti ongelmallista. Käytännössä uskonnon tunnit pidetäänkin joissakin kouluissa vain aamulla ja iltapäivisin, koska niitä ei pystytä sijoittamaan kaikille yhteisten oppituntien väliin. Pienempien uskontoryhmien opettajat ovat usein kiertäviä opettajia, joten tuntien järjestämisessä joudutaan ottamaan huomioon myös heidän aikataulunsa. Niinpä vähemmistöjen uskonnon opetus onkin usein kaikkein viimeisin oppitunti. Lisäksi vähemmistöjen uskonnon opettajat eivät ole aina akateemisesti pätevöityneitä. Tästä näkökulmasta kaikille yhteinen aine lisäisi myös tasa-arvoa. Lisäksi osa opettajista koki, että uskonnon opetuksesta ja elämänkatsomustiedosta on tullut hankalan organisoinnin vuoksi asennetasolla toisarvoisia aineita.

Haastattelija: Missä määrin tää monikulttuuristuminen aiheuttaa muntospaineita uskonnon opetukselle?

H1: No kyllähän se vaikuttaa koulun arkeen sillä tavalla, että ku tulee yhä enemmän, jos nyt pysytään näissä oman uskontokunnan mukaisissa, että kun rupee olemaan vaikka kuin monta eri uskonnon opetusta koulussa, niin kyllähän siinä ihan näitä käytännön järjestelyongelmia on. Se on selvä. Kyllähän se uskonto ainakin tuolla meidän yläasteella on vähän semmoinen, sanoisin toisen luokan aine, mut- 
ta et kuitenkin sellainen, että eka pannaan niinku ne lukujärjestykseen ne aineet, missä on koko luokka ja uskonnolle jää sitten ne aamu- tai iltatunnit. Et sitten jos se olis kaikille yhteinen, niin sitten se olis sillä tavalla tasavertaisessa asemassa muidenkin oppiaineitten kanssa.

H9: Esim. islamin tunnille tulee oppilaita muistakin alueen kouluista, niin silloin se yleensä tarkoittaa sitä, että se [islamin] tunti on viimeisenä iltapäivästä ja tääkin on mun mielestä tylsää, että aina ne vähemmistöihin kuuluvat oppilaat, niin niitten koulupäivät on niinku pidempiä ja hankalampia kuin muiden tän uskonnon opiskelun takia, että tää malli [kaikille yhteinen katsomusopetus] myös niinku tois semmoista tasavertaisuutta, että jos kuulut johonkin vähemmistöuskontoon, niin sun ei tarvi aina opiskella sitä neljän jälkeen.

Toisessa alemman tason kategoriassa kannatettiin kaikille yhteistä katsomusopetusta, koska monikulttuurisessa yhteiskunnassa oppilaiden on tultava toimeen eri tavoin uskovien ja ajattelevien kanssa. Opettajien mielestä on ristiriitaista, että oppilaat jaotellaan eri opetusluokkiin heidän uskonnollisen tai katsomuksellisen taustansa perusteella. Opettajat näkivät nykyisen järjestämismallin tältä osin synnyttävän jopa ennakkoluuloja toisin uskovia ja ajattelevia kohtaan. Käsityksen taustalla näyttää vaikuttavan niin sanottu kontaktihypoteesi, jonka mukaan tehokkain tapa vähentää eri ryhmien ennakkoluuloja on asettaa nämä ryhmät kontaktiin keskenään. Kontaktihypoteesin luojan Gordon W. Allportin mukaan on tärkeää, että kontakteja myös tuetaan sosiaalisesti ja institutionaalisesti. (Allport 1954, 261-281, ks. myös esim. Liebkind ja muut 2000, 57-59.) Yhteisen katsomusaineen uskottiin rakentavan todellista suvaitsevaisuutta ja aitoa monikulttuurisuutta. Myös Hanna Linnan (2001, $62-86$; 91) tutkielmassa opettajat tuntuivat kannattavan kaikille yhteisen katsomusaineen perustamista tästä näkökulmasta.

H9: Mun mielestä nää nuoret elää jo nyt yhdessä yhteisessä maailmassa, niin on ihan järjetöntä pistää ne uskonnon tunnilla aina erikseen, koska paljon hedelmällisempää niinku heidän maailmankuvansa rakentumisen kannalta olis se, että he turvallisessa ympäristössä koulussa katsomusaineen tunnilla voi kohdata sen toisen oppilaan katsomuksen, ilman että se niinku tarkoittais jotain kulttuuri-imperialismia kristinuskon hyväksi.

H7: Mä toivoisin, että meillä olis semmoista katsomusopetusta, jossa tää meidän oma kulttuuri olis keskeisellä sijalla, mutta samassa ryhmässä voisi yhtä aikaa olla useiden eri kulttuurien ihmisiä, jotka olisivat niinku vuorovaikutuksessa keskenään niin, että heillä olisi mahdollisuus muutenkin kuin erityisesti kutsuttuna imeä toisistaan niitä vaikutteita, mitä ne sitten tuolla oppii käytännön elämässä.

Opettajilla oli hyviä kokemuksia eri kulttuuritaustasta tulevien nuorten kohtaamisista ja niistä syntyvistä hedelmällisistä keskusteluista muiden opettami- 
ensa aineiden tunneilta, lähinnä historian, psykologian ja filosofian tunneilta. Opettajien mukaan myös oppilaan oman elämänkatsomuksen ja identiteetin muotoutuminen voisi tapahtua aivan yhtä hyvin kaikille yhteisessä katsomusaineessa muihin peilaamisen kautta. Lisäksi katsottiin, että evankelisluterilainen uskonnon opetus on jo nyt sellaista, että oppilaan elämänkatsomuksen muotoutumista tuetaan oman uskonnon suuntaan vain sisällöllisellä korostuksella. Heidän mukaansa mitään näkökulman muutosta uskontojen käsittelyyn ei tarvitsisi evankelisluterilaisessa uskonnon opetuksessa tehdä, jos aloitettaisiin kaikille yhteinen katsomusopetus.

Haastattelija: Miten sitten, kun sää oot tässä puhunut paljon siitä, että on tosi tärkeetä, että omat juuret ja omakohtainen ajattelu kehittyis, et jos olis tämmöinen yhteinen opetus, niin miten sää ajattelet sen mahdollistuvan siinä mallissa?

H12: Musta tuntuu, että sellaisilla jutuilla, mitä mää oon tässä aikaisemminkin sanonut, eli se ilmapiirin luominen on hirveen tärkeetä uskonnon opetuksessa ja varsinkin sellaisessa uskonnon opetuksessa, jossa on tarkoituksena oppilaiden tuoda omia näkökulmia, ja omia toisistaan poikkeavia näkökulmia esille. Eli jos on luottamuksellinen ja jotenkin turvallinen ja avoinkin ilmapiiri. Sitten se, että miten voida ymmärtää joitakin ihan toisenlaisia kulttuureja ja toisenlaisia näkökulmia, niin kyllä se on aikamoinen haaste opettajanakin ymmärtää kaikkea ja jotenkin innostua kaikesta, mutta ei se mun mielestä mitenkään mahdotonta oo ja just keskustelu on hyvä keino, että oppilaat voi tehdä kysymyksiä jollekin muslimille, joka selittää jostakin rukouksesta ja rukousasennoista ja niiden tärkeydestä. Mun mielestä semmoinen malli, että jos olis kaikki siinä uskonnon opetuksessa, niin se poistais hirveen paljon ennakkoluuloja ja tekis paljon enemmän tämmöistä maailmaa ymmärrettävämmäksi. Mun mielestä on yksinkertaisesti vaan niin, että jos ihmiset keskustelee ja pui jotakin ajatusten perusteita, niin kyllä siitä monesti syntyy enemmän rauhaa ja suvaitsevaisuutta, kuin että jos keskustelua ei olis ollenkaan.

Kolmannessa alemman tason kategoriassa kaikille yhteistä katsomusainetta kannatettiin, koska laaja-alainen uskonnollinen ja katsomuksellinen yleissivistys haluttiin taata muillekin kuin evankelisluterilaisille oppilaille. Evankelisluterilaista uskonnon opetusta pidettiin yleissivistävämpänä opetuksena kuin muiden uskontojen antamaa opetusta.

H6: En tiedä sitten kuinka paljon kaikissa muissa eri uskontojen opetuksissa tulee huomioiduksi nää muut uskonnot ja näin, että mun mielestä, voi nyt puhua vaan omasta näkökulmasta, niin tässä luterilaisessa uskonnon opetuksessa niin yhä enenevässä määrin on pyritty huomioimaan tää monikulttuuristuminen, mut sitten toisaalta herää kysymys, että miten sitten on näissä muissa. Mä uskon, että elämänkatsomustiedossa se tulee tää monikulttuurisuus hyvin voimakkaasti ja toisaalta muissa uskonnon opetuksen muodoissa, että kuinka paljon niissä tulee sitten tää monikulttuurisuus vai keskitytäänkö vain siihen omaan. [...] Kaikilla olis sitten [yhteisessä katsomusaineessa] mahdollisuus saada laaja-alaista uskonnon opetusta, 
koska kyllä mun mielestä on äärimmäisen tärkeetä, kuten sanoin tuossa aikaisemmin, että monikulttuurisuus parhaimmillaan pitää sisällään tän vuorovaikutuksen, niin mun mielestä on tärkeetä, että myöskin islamia opiskelevat tietää kristinuskon perusteita. Ne asuu Suomessa, jossa kristinuskolla on hyvin tärkee historia, keskeinen historia, ja edelleenkin se on hyvin paljon läsnä. Toivoisin kovasti, että heilläkin olis myös sen opetusta. En tiedä kuinka paljon sitten on.

Opettajien mielestä monikulttuurisuus ja toisten uskontojen opiskelu kunnioittavassa ilmapiirissä on otettu huomioon evankelisluterilaisessa uskonnon opetuksessa paremmin kuin muiden uskontojen opetuksessa. Kaikille yhteistä katsomusainetta kannatettaessa evankelisluterilaisen uskonnon opetuksen laaja-alaisuus ja yleissivistävä luonne haluttiin taata myös muiden uskontokuntien jäsenille.

Neljännessä kategoriassa katsomusaineiden opetuksen toivottiin yhdistyvän osittain. Nykyisestä järjestelmästä haluttiin säilyttää osittainen oman uskonnon opetus. Kaikille yhteinen katsomusopetus nähtiin tärkeäksi, jotta oppilaat oppisivat elämään eri tavoin ajattelevien kanssa. Oman uskonnon opetus haluttiin säilyttää yhteisen aineksen rinnalla, jolloin oppilaat saisivat omasta uskonnosta syvemmin tietoa ja oppilaiden oma identiteetti ja elämänkatsomus voisi rakentua turvallisessa ja tutussa viitekehyksessä.

H9: Mä oon sitä mieltä, että tästä [nykyisestä mallista] pitäis luopua kokonaan ja pitäis mennä semmoiseen järjestelmään, että kaikki saa koulussa katsomuksellista tai eettistä opetusta, vähän samalla periaatteella kun maantiedossa opiskellaan enemmän niinku Suomen maantietoa tän tämmöisen kotiseutuperiaatteen mukaan niin siellä opiskellaan tietty määrä kristinuskoa sillä perusteella, että me eletään kristillisessä maassa ja kulttuurissa ja sitten tämmöisiä yleiseettisiä kysymyksiä ja sitten osa olis sitä oman uskonnon opiskelua.

Haastattelija: Eli osa tunneista olis erikseen ja osa yhdessä?

H9: Niin ja se jako vois olla joku tämmöinen 2/3 yhdessä ja 1/3 erikseen.

Haastattelija: Sanoit, että 1/3 olis sitten sitä omaa opetusta, niin minkä takia sitten se oma opetus pitää olla omassa ryhmässään?

H9: No on se kuitenkin hirveen tärkeetä, että siinä on se oma tuttu viitekehys ja ympäristö. Se ei mene siihen semmoiseen kilpailuasetelmaan, tai että jotenkin luodaan puitteet, missä, koska ihmiset kuitenkin kaipaa sitä yhteisöllisyyttä tässä monikulttuurisessa ympäristössäkin, et voi niinkö kaikessa rauhassa keskittyä sen opiskelemiseen, että mihin me uskotaan tai mitä tämä kirkko opettaa. Eli kyl mä koen, että se myös sen uskonnonvapauden toteutumisen kannalta on tärkeää, mutta siinä mun mielestä nää kirkot itse saavat ottaa vastuuta. 
Oman uskonnon opetus ei tässäkään mallissa olisi mitään tunnustuksellista opetusta. Erillinen oman uskonnon opetus antaisi kuitenkin mahdollisuuden syventyä omaan uskontoon liittyvään tietoon ja kysymyksiin. Tässä näkyy myös selvästi ajatus siitä, että monikulttuurisessa yhteiskunnassa on tärkeää oppia tunnistamaan se kulttuurinen viitekehys, josta itse maailmaa tarkkailee: Sen tunnistamiselle olisi annettava tilaa koulun uskonnon opetuksessa.

Joidenkin opettajien mielestä kaikille yhteinen katsomusaine sopisi erityisesti lukioon. Lukiolaisilla ajatellaan olevan jo riittävä kyky abstraktiin ja kriittiseen ajatteluun. Oma uskonto on näiden opettajien mielestä vielä yläasteikäiselle turvallinen viitekehys uskontojen opiskelussa. Suurin osa kaikille yhteistä katsomusainetta puoltavista opettajista kannatti kuitenkin aineen perustamista sekä yläasteelle että lukioon.

\section{Käsitys uskontotieteellisen aineksen tärkeydestä}

Opettajien käsitykset monikulttuurisuudesta ja uskonnon opetuksen tulevaisuudesta muodostivat yhden kategorian, joka ei ollut riippuvainen siitä, mikä olisi katsomusopetuksen järjestämismalli. Uskonnon opettajien mukaan yhteiskunnan monikulttuuristuminen lisää uskontotieteellisen tiedon merkitystä uskonnon opetuksessa. Opettajien mielestä uskonnon opetuksessa tulisi olla lisää ainesta, jossa käsiteltäisiin monikulttuurista ja moniuskontoista todellisuutta Suomessa ja maailmalla.

Haastattelija: Missä määrin sun mielestä monikulttuuristuminen vaikuttaa uskonnon opetuksen kehittämiseen?

H8: Kyl se pakottaa kehittämään. On otettava yhä enemmän selvää ja yritettävä yhä enemmän ymmärtää toisia uskontoja ja kulttuureja, että täydennyskoulutusta tarvitaan tavallaan koko ajan, ettei se tieto jää kauheen pinnalliseksi myöskään.

Jos lukion opettajat saisivat yhden pakollisen lisäkurssin, he valitsisivat sen sisällöksi maailman uskontojen tai Suomen uskontojen kurssin. Osa opettajista toivoi myös maailman uskontojen kurssia pakolliseksi lukion kolmen pakollisen kurssin joukkoon. Opettajat toivoivat lisää ajankohtaisia, oppilaita kiinnostavia virikemateriaaleja, esimerkiksi dokumentteja, joissa huomioitaisiin uskovan yksilön näkökulma. Tällainen materiaaliaines auttaisi oppilaita hahmottamaan uskontoa enemmän yksilön kokemuksen tasolla vaikuttavana ilmiönä. Opettajien mielestä monikulttuurisen yhteiskunnan uskonnon opetuksen tulisi käsitellä uskontoja enemmän ilmiöinä kuin esimerkiksi oppirakennelmina. 
Evankelisluterilaisen uskonnon opetuksen sisällöllisenä kehityssuuntana on ollut jo pitkään joidenkin teologisten alojen kuten esimerkiksi systemaattisen teologian oppiaineksen väistyminen uskontotieteellisen aineksen tieltä (mm. Iisalo 1970, 83-84). Tästä huolimatta opettajat olivat valmiita lisäämään entisestään uskontotieteellisen aineksen määrää. Uskontotieteellisen tiedon korostuminen uskonnon opetuksessa asettaa suuret haasteet uskonnon opettajien omalle aineenhallinnalle. Ajankohtainen, konkreettinen ja syvällinen tieto vaatii opettajien mukaan heiltä itseltään jatkuvaa aktiivisuutta aineenhallinnan päivittämisessä. Opettajat kokivat, että heidän oma uskontotieteellinen aineenhallintansa ei ole ollut aina riittävä. He toivoivatkin, että uskonnon opettajien koulutuksessa painotettaisiin tulevaisuudessa enemmän uskontotieteen opintoja.

H2: Vieraat uskonnot ja kulttuurit! No itse asiassa se on ehkä sellainen kurssi, missä mää niinku tunnen alamittaisuutta omien tietojeni kanssa. Et mun pitäis opettaa jotain vaikka hindulaisuudesta. Mitä mä siitä tiedän! En mää nyt siitä tiedä sen enempää, mitä nyt jossain suunnilleen lukion oppikirjassa on. Se on niinku ihan saman tasoista kamaa, mitä mää siitä tiedän, ku mitä mää voisin kuvitella, että Intiassa opetetaan jostakin luterilaisuudesta. Ettei kovin syvällistä. Tavallaan siinä tarttis niinkö lisäkurssitusta. [...] Monta kertaa, tai siis silloin tällöin tulee sellainen, et vitsi tästä pitäis niinku tietää ja ymmärtää ja käsittää paljon enemmän, etttä vois alkaa opettaa niinku aidosti, että miten vaikka Intiassa, mikä on intialainen kulttuuri. Minusta vieraat uskonnot ja kulttuurit; mää koen oman koulutukseni riittämättömäksi, että semmoista samanlaista riittämättömyyden tunnetta ei oo oikeestaan muissa oppisisällöissä. Siinä se iskee kaikkein pahiten vastaan.

Uskonnon opettajien ammattirooli on kehittynyt opettajien mukaan yhä enemmän koulun uskonnolliseksi ja katsomukselliseksi asiantuntijaksi. Myös Kallioniemen (1998, 165-166) tutkimuksessa opettajat painottivat ammattiroolinaan kulttuuriperinteen opettajan ja teologisen asiantuntijan roolia. Opettajien mukaan tämä rooli on otettu vastaan myös opettajanhuoneessa. Monikulttuurisuuskysymyksissä käännytään yhä useammin uskonnon opettajan puoleen ja uskonnon opettajat ovat yhä useammin mukana koulun elimissä, joissa paneudutaan oppilashuoltoon ja monikulttuurisuuskysymyksiin. Myös tästä näkökulmasta opettajien uskontotieteellisen koulutuksen määrään tulee lisäämispaineita. Uskonnon opettajat myös kokevat monikulttuuristumisen lisänneen heidän oppiaineensa arvostusta yleisesti.

H11: Kyl se [monikulttuurisuus] on uskonnon opetukselle iso haaste ja sitten tämmöinen sillanrakentajan rooli: ihan samalla tavalla opettajana tuolla opettajanhuoneessa, niin antaa informaatiota työkavereille, tai suoraan sanottuna joskus oikaista niitä puheita jotenkin hienovaraisesti. 
Haastattelija: Missä määrin uskonnon opetuksen asema muiden koulun aineiden joukossa on mielestäsi muuttunut yhteiskunnan monikulttuuristumisen myötä?

H3: Mulla on sellainen älytön ajatus, että se olis vähän jopa saanut enemmän arvostusta. Et silloin kun mä aloitin tässä koulussa, niin oli tämmöinen että "no niitten oppilaitten pitää nyt mennä sinne, niillä on vaan ussaa, ei sil oo väliä, menkööt!", mutta ei kukaan puhu tällaista enää ainakaan tässä talossa, et "niillä on vaan ussaa". Kyllä tän aineen arvostus on ainakin tässä talossa noussut, mutta mää luulisin, että silleen yhteiskunnassakin, et sen näkee, et yhteiskunta, osa siitä ainakin, osaa arvostaa tätä.

\section{Tulosten pohdintaa}

Opettajien käsitykset uskonnon opetuksen tulevaisuudesta monikulttuuristuvassa yhteiskunnassa keskittyivät pitkälti katsomusopetuksen järjestämismallin ympärille. Haastatelluista opettajista suurin osa piti kehitystä kohti kaikille yhteistä katsomusainetta joko valitettavan väistämättömänä tai toivottavana päämääräänä. Kaikille yhteiseen katsomusaineeseen liittyviä kysymyksiä on tutkittu Suomessa varsin vähän, eikä käytännön ongelmia ole tarkasteltu juuri lainkaan. Markku Pyysiäinen (1982) vertasi väitöstutkimuksessaan Suomen peruskoulun tunnustuksellista uskonnon opetusta, ortodoksista uskonnon opetusta ja elämänkatsomustietoa Ruotsin uskontotietoon. Tutkimus kohdistui Suomen osalta vuoden 1970 opetussuunnitelmaan. Voimassaolevat opetussuunnitelmat ovat Pyysiäisen tutkimuskohteen jälkeen jo kolmannet. Olisikin syytä tarkastella ajankohtaisen aineiston valossa esimerkiksi Ruotsin, Norjan ja Tanskan uskontotiedon opetussuunnitelmia ja uskonnon opetuksen järjestämismalleja ja pohtia, mitkä olisivat niiden soveltamismahdollisuudet Suomen oloihin.

On huomattava, että katsomusopetus on käsitteenä jokseenkin epäselvä, vaikka se on vakiintunut myös tutkimukselliseen käyttöön (Pyysiäinen 2000, 2; Kallioniemi 2002, 30). Ei ole kuitenkaan olemassa teoreettista tutkimusta, jossa käsitettä tarkasteltaisiin suhteessa oppiaineiden tieteenalastruktuuriin ja metodologiaan. Tämän vuoksi on vaikea määritellä, millä perusteella kyseisistä aineista on muodostettu mahdollinen oppiaine. Selvää kuitenkin on, että juridisesta näkökulmasta katsottuna katsomusaineksi voidaan luokitella eri uskontokuntien uskonnon opetus ja elämänkatsomustieto. Lisäksi katsomusaineisiin liittyviä yhteisiä teemoja ovat ainakin erilaisiin katsomuksiin, maailmankuviin ja arvoihin liittyvät kysymykset (Kallioniemi 2002, 30-33).

Opettajat kiinnittivät myös huomiota kaikille yhteisen katsomusopetuksen taustaoletuksiin, erityisesti etiikan opetuksen kohdalla. Arto Kallioniemi (2001, 37-60) on vertaillut artikkelissaan elämänkatsomustiedon ja evanke- 
lisluterilaisen uskonnon opetuksen opetussuunnitelmien tieteenalastruktuuria. Etiikan kohdalla evankelisluterilainen uskonnon opetus ei eroa Kallioniemen mukaan elämänkatsomustiedosta. Tässä Kallioniemi muistuttaa luterilaiseen perinteeseen liittyvästä periaatteesta, jonka mukaan etiikka ja moraali ovat ennen muuta järjen asioita (vrt. Hallamaa 1998, 99). Jos tulevaisuudessa siirrytään kaikille yhteiseen katsomusaineeseen, on tärkeää tiedostaa, ettei opetus olisi tällöinkään arvovapaata. Siksi on kysyttävä, missä määrin tällainen järjestämismalli heijastelisikin vain luterilaisuudelle tyypillistä lähestymistapaa etiikkaan. Olisi tärkeää tutkia, miten etiikanopetus ymmärretään muiden uskontojen keskuudessa, ja minkälaiselle yhteiselle arvopohjalle katsomusopetuksessa annettava etiikanopetus voitaisiin rakentaa.

Monikulttuurisen yhteiskunnan periaatteiden mukaisesti kysymystä uskonnon opetuksen tulevaisuudesta tulisi käydä keskustelufoorumissa, jossa olisivat mukana eri uskonto- ja katsomusryhmät. Tässä tutkimuksessa haastateltiin vain evankelisluterilaisen uskonnon opettajia. Jatkossa tulisi tutkia myös muiden uskontojen ja elämänkatsomustiedon opettajien käsityksiä. Tutkimus keskittyi pääkaupunkiseudulle, jossa monikulttuuristumiskehitys on ollut voimakkainta. Uskonnon opetusta koskevien ratkaisujen yhteydessä on tietenkin huomioitava myös muualla Suomessa vallitseva kasvatustodellisuus.

Uskonnon opettajien mukaan yksilön näkökulma pitäisi huomioida voimakkaammin vieraiden uskontojen opetuksessa. Tällainen lähestymistapa antaisi oppilaille paremmat valmiuden kohdata toisin uskovia ja ajattelevia. Myös Christer Hedin (1997) on pohtinut artikkelissaan, miten uskonnon opetus voisi estää ennakkoluulojen syntymistä toisin uskovia ja toisista kulttuureista tulevia kohtaan. Hänen mukaansa yhtenä ennakkoluuloja vähentävänä tekijänä voisi olla se, että uskonto nähtäisiin voimakkaammin suhteessa psykologiaan ja sosiologiaan. Uskonnon opetuksessa uskonto tulisi nähdä entistä enemmän yksittäisten ihmisten tulkinnan kautta. (Hedin 1997, 191.) Monikulttuuristumiskehityksen myötä uskontotieteen opintoja pitäisi integroida vahvemmin uskonnon opettajien koulutukseen.

Opettajien mukaan uskonnon opetusta tulisi kehittää sellaisesssa hengessä, jossa sitoudutaan sekä uskontojen väliseen vuoropuheluun että oman uskonnollisen identiteetin etsimiseen ja säilyttämiseen. Oman uskonnon mukaan määräytyvää uskonnon opetuksen järjestämismallia on perusteltu usein sillä, että uskonnon opetus on hyvä aloittaa siitä uskonnollisesta ja katsomuksellisesta pohjasta, jonka keskellä oppilaat ovat kasvaneet. Vasta tämän jälkeen siirryttäisiin muiden uskontojen ja katsomusten tarkasteluun. (Ks. esim. Kähkönen 1976, 237-242.) Monikulttuurisessa yhteiskunnassa oppilas ei voi kuitenkaan hahmottaa omaa uskonnollista identiteettiään ilman, että hän olisi jo tietoinen uskonnollisesta moninaisuudesta. Tämän vuoksi esimerkiksi Heimbrockin ja kumppaneiden (2001, 9-10) mukaan uskontojen oppiminen ja uskonnoista 
oppiminen olisi hedelmällistä aloittaa näkökulmasta, jossa huomioitaisiin uskontojen moninaisuus.

Aineistosta löydetyt kategoriat kuvaavat monipuolisesti uskonnon opetuksen kehittämistarpeita monikulttuuristuvassa yhteiskunnassa. Ne ilmentävät samalla, kuinka monisyinen kysymys uskonnon opetuksen tulevaisuudesta on. Vaikka muodostetut kategoriat eivät kuvaa yksittäisten uskonnon opettajien ajattelua, ne voivat toimia hyvin keskustelun pohjana pohdittaessa uskonnon opetuksen kehittämistä ja tulevaisuutta. Monikulttuuristuvassa yhteiskunnassa annettavan uskonnon opetuksen haasteet ja tulevaisuuden skenaariot saivat opettajien käsitysten kautta syvempiä ja vivahteikkaampia tulkintoja. Tutkimus osoittaa, että uskonnon opettajat ovat pohtineet uskonnon opetuksen asemaa, tehtäviä ja tulevaisuutta monista eri näkökulmista. Uskonnon opettajat tiedostavat selvästi uskonnon opetuksen merkittävän roolin monikulttuurisen yhteiskunnan rakentamisessa.

\section{Lähteet}

Allport, G. W. (1954). The Nature of Prejudice. New York: Addison-Wesley Publishing Company Inc.

Autio, S. (2001). Muut uskonnot lukion evankelisluterilaisen uskonnon oppikirjoissa vuosina 1948-1998. Kasvatustieteen laudaturtutkielma. Helsingin yliopisto. Kasvatustieteellinen tiedekunta.

Eduskunnan keskustelu hallituksen esityksen 170/2002 pohjalta.. http://www.eduskunta.fi/thwfakta/tmp/ptk_112_2002_ke_3.htm, luettu: 29.10.2002.

Hallamaa, J. (1998). Millaista etiikkaa? Teoksessa Pyysiäinen, M. \& Seppälä, J. (toim.), Uskonnonopetuksen käsikirja, 93-102. Juva: WSOY.

Hargreaves, A. (1994). Changing Teachers, Changing Times. Teacher's Work and Culture in the Postmodern Age. London: Continuum.

Hedin, C. (1997). Identity and Prejudices. In Holm, N. G. (toim.), The Familiar and the Unfamiliar in the World Religions. Challenges for Religious Education Today. Religionsvetenskapliga skrifter nr 34, 199-223. Åbo: Åbo Akademis tryckeri.

Heimbrock, H. G., Scheilke C. Th. \& Schreiner, P. (2001). Introduction. In Heimbrock, H-G \& Scheilke C. Th \& Schreiner, P. (toim.), Towards Religious Competence. Diversity as a Challenge for Education in Europe, 9-20. Schriften aus dem Comenius-Institut.

Helsingin Sanomat, (2003). Mikä on uskonnon harjoittamista? Kuntaliitto esittää kouluun uskontotietoa. 20.1.2003.

Heino, H. (1997). Mihin Suomi tänään uskoo? Juva: WSOY.

Iisalo, T. (1970). Vieraiden uskontojen opetuksesta. Teoksessa Uudistuva uskonnonopetus. Uskonnon opetuksen käsikirja, 83-92. Helsinki: WSOY. 
Kallioniemi, A. (1994). Uuden opetussuunnitelman arviointia uskonnon didaktiikan näkökulmasta. Teoksessa Tella, S. (toim.), Näytön paikka. Opetuksen kulttuurin arviointi, 33-42. Helsingin yliopisto. Opettajankoulutuslaitos. Tutkimuksia 129. Helsinki: Yliopistopaino..

Kallioniemi, A. (1997). Uskonnon opettajien ammattikuva. Helsingin yliopisto. Opettajankoulutuslaitos. Tutkimuksia 180. Diss. Helsinki: Yliopistopaino.

Kallioniemi, A. (1998). Huomisen uskonnon opetus. Kristillinen kasvatus. 2-3/1998. $7-11$.

Kallioniemi, A. (2001). Uskonnon ja elämänkatsomustiedon sisältötiedon ja tieteenalastruktuurin vertailua peruskoulun vuoden 1994 opetussuunnitelmien pohjalta. Didacta Varia. Vol. 6 (1), 2001, 37-60. Helsingin yliopisto. Opettajankoulutuslaitos..

Kallioniemi, A. (2002). Katsomusaineiden opetuksen tutkimuksesta. Kristillinen kasvatus. $2-3 / 2002,30-33$.

Kansanen, P., Tirri, K., Meri, M., Krokfors, L., Husu, J., \& Jyrhämä, R. (2000). Teachers' pedagogical thinking. Theoretical landscapes, practical challenges. New York: Peter Lang.

Kähkönen, E. (1976). Uskonnon opetuksen asema Suomen koulunuudistuksessa 19441970. Suomalaisen teologisen kirjallisuusseuran julkaisuja 101. Diss. Helsingin yliopisto. Kemijärvi: Koillis-Lapin Kirjapaino.

Kääriäinen, K., Niemelä, K. \& Ketola, K. (2003). Moderni kirkkokansa. Suomalaisten uskonnollisuus uudella vuosituhannella. Kirkon tutkimuskeskuksen julkaisuja 82. Jyväskylä: Gummerrus-kirjapaino.

Lait kansakoulun järjestysmuodon perusteista 137/1923.

Larsson, S. (1986). Kvalitativ analys-exemplet fenomenografi. Lund: Studentlitteratur.

Liebkind, K. (2000). Kun kulttuurit kohtaavat. Teoksessa Liebkind, K. (toim.), Monikulttuurinen Suomi. Etniset suhteet tutkimuksen valossa, 13-27. Helsinki: Gaudeamus.

Liebkind, K. ja (keitä ovat) muut. (2000). Kannattaa tutustua paremmin. Teoksessa Liebkind, K. (toim.), Monikultuurinen Suomi. Etniset suhteet tutkimuksen valossa, 56-67. Helsinki: Gaudeamus.

Linna, H. (2001). Lukion uskonnon opetus 2000-luvun alussa. Pääkaupunkiseudun rehtorien ja uskonnon opettajien käsityksiä lukion uskonnon opetuksen haasteista ja kehittämisestä. Pro gradu-työ. Helsingin yliopisto. Teologinen tiedekunta.

Lukiolaki 455/2003, 9§. Uskonnon ja elämänkatsomustiedon opetus.

Mauranen, M-L. (1982). Vieraat uskonnot. Teoksessa Tamminen, K. \& Vesa, L., Miten opetan uskontoa? Uskonnon didaktiikka, 144-148. Saarijärvi: Kirjapaja.

Perusopetuslaki 454/2003, 13§. Uskonnon ja elämänkatsomustiedon opetus.

Pyysiäinen, M. (1982). Tunnustuksellinen, tunnustukseton ja objektivinen uskonnon opetus. Opetussuunnitelma-analyysi Suomen ja Ruotsin peruskoulun uskonnon opetuksen tavoitteista ja sisällöstä. Diss. Helsingin yliopisto Teologinen tiedekunta. Jyväskylä: Kirjapaja.

Pyysiäinen, M. (1998). Koulun uskonnon opetuksen luonne. Teoksessa Pyysiäinen, M. \& Seppälä, J. (toim.), Uskonnonopetuksen käsikirja, 41-68. Juva: WSOY. 
Pyysiäinen, M. (2001). Yksi oppiaine, seitsemän opetussuunnitelmaa. Peruskoulun ja lukion opetushallituksen 1990-luvulla vahvistamien uskonnon opetussuunnitelmien tunnustuksellinen luonne. Helsingin yliopisto. Opettajankoulutuslaitos. Tutkimuksia 223. Helsinki: Hakapaino.

Saine, H. (2000). Uskonnon opetus Suomen oppivelvollisuuskoulussa 1900-luvulla. Turun yliopisto. Diss. Turku: Painosalama.

Skeie, G. (2001). Citizenship, Identity Politics and Religious Education. In Heimbrock, H.-G., Scheilke C. Th. \& Schreiner, P. (eds.), Towards Religious Competence. Diversity as a Challenge for Education in Europe, 237-252. Schriften aus dem Comenius-Institut.

Tilastokeskus (2002). Ulkomaalaiset ja siirtolaisuus 2001, Väestö 2002:8. Helsinki: Valopaino.

Tirri, K. (1995). Moniarvoisuus on haaste uskonnon didaktiikalle. Kristillinen kasvatus. Nro 2. 20-23.

Uskonnonvapauslaki 453/2003.

Uskonnonvapauslaki 267/1922. 



\section{III}

\section{Elämänkatsomustiedon opetus}





\title{
Elämänkatsomustiedon opetuksen pitkän aikavälin kehitystehtävistä
}

\author{
Jussi Kotkavirta
}

\section{Tiivistelmä}

Artikkelissa pohditaan katsomusaineiden kokonaisuntta ja erityisesti elämänkatsomustiedon asemaa. Tekijän näkemyksen mukaan ihannetilanne olisi, jos nykymuotoisen uskonnon ja elämänkatsomustiedon tilalle luotaisiin kokonaan uusi oppiaine. Sikäli kuin tämä ei ole mahdollista oppiaineet tulisi tekijän mukaan tehdä keskenään valinnaisiksi. Vasta tämän jälkeen elämänkatsomustieto voisi oppiaineena kasvaa ja toteuttaa niitä mahdollisuuksia, joita siihen periaatteessa sisältyy. Kirjoituksen loppuosassa tekijä pohtii sitä, miten elämänkatsomustiedon sisällöt voitaisiin jäsentää sillä tavoin, että kurssit tukevat mahdollisimman hyvin oppilaiden käytännöllisen identiteetin rakentumista. Tekijä tarkastelee erilaisia identiteetin rakentumisen kannalta keskeisiä ihmissuhteiden lajeja ja esittää, että oppiaineen sisältökokonaisuuksia voidaan jäsentää näiden mukaan. Tekijän käsityksen mukaan perusajatusta voi soveltaa myös uskonnon kurssisisältöjen suunnittelussa.

Avainsanat: elämäkatsomustieto, identiteetti, ihmissuhteet, kasvatus, katsomusaineet, opetus

\section{Aluksi}

Meillä on nyt kahden vuosikymmenen kokemus elämänkatsomustiedosta oppiaineena. Tänä aikana elämänkatsomustiedon asema on monessa suhteessa vakiintunut ja oppiaineelle on muodostunut oman identiteettinsä. Sen luonteesta ja tavoitteista näyttää muodostuneen jonkinlainen yksimielisyys. Uusien opetussuunnitelmien perusteiden laatiminen peruskouluun ja lukioon vahvisti oppiainetta merkittävästi ja loi aiempaa vankemman pohjan koulukohtaiselle työlle.

Elämänkatsomustiedon identiteetti ei kuitenkaan vielä ole kovin vahva. Oppiaine on yhä edelleen enemmänkin hallinnollisten linjanvetojen, erilaisten poliittisten kompromissien ja lyhyen aikavälin käytännön tarpeiden sanelema aikaansaannos kuin oppilaiden persoonallisen kasvun tarpeita koskevien periaatteellisten pohdiskelujen ja kehitystyön tulos. 
Pohdin seuraavassa lyhyesti, mitä elämäkatsomustiedon pitäisi olla ja mitä se voisi olla, jos lähtökohdaksi otetaan oppilaiden yksilöllinen kehitys persoonina ja aktiivisina kansalaisina. Aloitan kuvitellusta tilanteesta, joka nähdäkseni olisi ihanteellinen: siinä ei olisi sen enempää kuin uskontoa kuin elämänkatsomustietoakaan nykymuotoisina oppiaineina, vaan jokin kokonaan uusi katsomusaine. Oppiaine olisi kaikille yhteinen. Tästä Ruotsin mallin tapaisesta tilanteesta etenen sitten kohti lyhyemmän aikavälin kehitysnäkymiä sekä käytännöllisempiä kehitystehtäviä. Tarkasteluni liikkuu varsin yleisellä tasolla jo siksi, että minulla ei juuri ole henkilökohtaista tuntumaa itse koulutyöhön. Elämänkatsomustiedon opettajien kouluttajana olen toiminut kyllä pitkään.

Tunnetusti termi "elämänkatsomus" on alun perin byrokraattinen oivallus, ja sitä onkin likimain mahdoton kääntää millekään toiselle kielelle. "Elämänkatsomustieto" ei myöskään ole neutraali nimi, vaan se suuntaa oppiainetta koskevia mielikuvia ja ajatuksia tiettyihin suuntiin ja myös rajaa niitä.

Nimi "elämänkatsomustieto" luo oppiaineesta tietopainotteisen kuvan, johon voi olla vaikea sovittaa vaikkapa elämäntaidollisia tai esteettisiä aiheita. Oppiainetta periaatteellisesti pohtivissa kirjoituksissa onkin joskus jääty ikään kuin nimen vangeiksi ja juututtu maailmankuvan, maailmankatsomuksen ja elämänkatsomuksen käsitteiden keskinäisiin suhteisiin ja tulkintoihin.

En suinkaan halua kiistää näiden kysymysten selventämisen merkitystä, mutta ajattelen, että kehitystyön painopistettä tulisi siirtää tiedollisista sisällöistä toisaalle. Nähdäkseni olennaista olisi pohtia nykyistä enemmän, miten oppiaineessa voidaan parhaiten tukea ja edistää oppilaiden valmiuksia käsitellä oman elämänsä merkitystä, tarkoitusta ja henkilökohtaista identiteettiä koskevia kysymyksiä.

\section{Mikä olisi katsomusopetuksen ihannetilanne?}

Lähden siis siitä, että pitkällä aikavälillä koulun katsomusopetus olisi syytä irrottaa uskonnosta oppiaineena, jolloin myös elämänkatsomustieto nykymuodossaan kävisi tarpeettomaksi. Tällöin katsomusopetusta voitaisiin lähteä suunnittelemaan uudelta pohjalta ja yhtenä kokonaisuutena. Ihanteellista olisi, jos tässä suunnittelutyössä voitaisiin ottaa etäisyyttä nykyisistä oppiaineisiin sitoutuneista intresseistä. Lähtökohtana olisi ainoastaan kysymys, minkälaisen katsomusaineen oppilaat itse asiassa tarvitsisivat, minkälaisia tiedollisia kokonaisuuksia eri vaiheissa opetettaisiin ja miten oppilaiden persoonallisten valmiuksien kehittymistä kussakin vaiheessa tuettaisiin, jotta heistä kasvaisi - kuten nykyisissä opetussuunnitelmien perusteissa sinänsä osuvasti todetaan - itsenäisiä, suvaitsevaisia, vastuullisia ja arvostelukykyisiä yhteisön jäseniä. 
Mitä kaikkea oppilaiden sitten pitäisi katsomusaineissa oppia? Sekä perusopetuksen että lukion elämäkatsomustiedon ja myös uskonnon uusiin opetussuunnitelmien perusteisiin on onnistuttu muotoilemaan hyvin olennaisia tavoitteita ja myös tärkeitä sisällöllisiä kokonaisuuksia. Tiedollisesti oppilaiden tulisi oppia vähitellen jäsentämään elämisen katsomuksellisia ehtoja ja periaatteita monikulttuurisessa maailmassa ja ymmärtää ainakin perusasioita keskeisimmistä aateperinteistä.

Oppilaiden tulee osata hahmottaa kristinuskon mutta myös muiden keskeisten uskontojen luonnetta ja opinkappaleita. Uskontojen ohella heidän on kuitenkin opittava ymmärtämään myös muita katsomuksellisia ajatustapoja. Heidän tulisi oppia hahmottamaan eurooppalaista kulttuuriperintöä, joka alkaa sekä Ateenasta että Jerusalemista. Heidän pitäisi myös oppia ymmärtämään nykyaikaisen tieteellisen maailmankatsomuksen pääperiaatteita ja merkitystä henkilökohtaiselle elämänkatsomukselle.

Tiedollisten tavoitteiden lisäksi vähintään yhtä olennaista on kuitenkin se, että katsomusaineissa tuetaan oppilaiden henkilökohtaista kasvua ja kehittymistä aktiivisiksi kansalaisiksi, kypsiksi moraalisiksi persooniksi sekä mahdollisimman tasapainoisiksi yksilöiksi. Suuri haaste on se, miten kytkeä nämä kaksi puolta, tiedollinen ja kasvatuksellinen tehtävä yhteen toimivaksi ja luontevasti kehittyväksi kokonaisuudeksi.

Nykyisessä katsomusopetuksessa ollaan eri syistä varsin kaukana ihannetilanteesta, jossa tällainen yhdistäminen onnistuisi. Elämänkatsomustieto on ainakin suunnitelmien tasolla liian tietopainotteinen aine. Myös oppiaineen piirissä vallitseva näkemys lapsen ja nuoren moraalisesta kasvusta on liian velvollisuuseettinen ja kaukana polttavista identiteetin rakentumisen kysymyksistä.

Se, että katsomuksellisia asioita opetetaan yhtäältä uskonnossa, toisaalta elämänkatsomustiedossa, on monellakin tapaa ongelmallista. Uskonnon opetuksen tunnustuksellisuutta on kyllä väljennetty ja oppiaine on ottanut sisäänsä myös paljon tärkeitä asioita, jotka eivät suoranaisesti liity uskontoon. Kuitenkin kristinuskon opinkappaleet ja periaatteet muodostavat yhä edelleen opetuksen katsomuksellisen kehyksen, mikä rajaa ja rajoittaa asioiden käsittelyä kohtalokkaasti. Kun nuorten maailma - ja koulu sen mukana - muuttuu yhä monikulttuurisemmaksi, pyrkimys pitää kiinni evankelis-luterilaisesta uskonnon opetuksesta ikään kuin kaikille tarkoitettuna yleisaineena vaikuttaa yhä keinotekoisemmalta ja konservatiivisemmalta.

Sama pätee itse asiassa myös elämänkatsomustietoon. Vaikka tapana on korostaa, että elämänkatsomustieto ei ole uskonnon vasta-aine, oppiaineen luonne ja sisältö määrittyvät aivan liiaksi uskonnon negaationa ja uskonnon poissaolona oppiaineen sisällöistä. Oppiaine perustuu sekulaariin humanismiin, jonka alle on enemmänkin kerätty erilaisia liberaalis-humanistisia sisäl- 
löllisiä aiheita kuin muotoiltu johdonmukaista ja kattavaa sisällöllistä perusajatusta: On sitouduttu valistukseen ja tieteelliseen rationaalisuuteen, samalla kun uskontoihin ja erityisesti kristinuskoon on suhtauduttu hyvin torjuvasti. On korostettu ihmisoikeuksia, velvollisuusetiikkaa ja siihen pohjautuvaa näkemystä lasten moraalisesta kehityksestä. On korostettu demokratiaa ja liberaaleja arvoja, ja niin edelleen. Yhtä ja toista on myös saavutettu, mutta lopputulos on sittenkin varsin eklektinen, epämääräinen ja tavallaan myös rajoittunut.

Oma käsitykseni on, että ihanteellisessa katsomusopetuksessa tulisi käsitellä sekä uskonnollisia että humanistisia katsomuksia, mutta osana sellaista kokonaisuutta, joka ei rakennu kummankaan nykyisen oppiaineen varaan. Pitäisikin muodostaa uusi katsomuksellis-kasvatuksellinen oppiaine. Uskonnollisia sisältöjä siinä käsiteltäisiin enemmän kuin elämänkatsomustiedossa ja vähemmän kuin uskonnossa, ja eri tavalla kuin kummassakaan oppiaineessa. Muille katsomuksellisille suuntauksille ja ajatustavoille siinä annettaisiin enemmän tilaa kuin kummassakaan nykyisessä oppiaineessa.

Oppiaineen ensisijaisena lähtökohtana ja runkona pitäisi olla oppilaiden kehitykseen ja kasvuun liittyvät tarpeet, eivätkä eri katsomukselliset suuntaukset ja niiden intressit. Taustalla on ajatus, että uskonnon opettamisen paikka sinänsä on jossakin muualla kuin julkisessa koulussa.

\section{Miten elämänkatsomustieto voisi kehittyä?}

On ilmeistä, minkä vuoksi edellä olevan kaltaiset ajatuskulut tuskin saavat laajaa hyväksyntää sen enempää uskonnon kuin elämänkatsomustiedonkaan kehittämisestä vastaavien tahojen piirissä. On kuitenkin tärkeää koettaa tarkastella nykytilannetta kriittisesti ja riippumattomasti - ikään kuin ulkopuolisesta näkökulmasta.

Edellä olen esittänyt joitakin ajatuksia ihannetilanteesta, joka on hyvin kaukana realiteeteista. Jos katsomusopetuksen kehittämistä tarkastellaan astetta lyhyemmän aikavälin näkökulmasta, niin keskeistä nähdäkseni olisi tehdä uskonnosta ja elämänkatsomustiedosta kaikille oppilaille valinnaiset oppiaineet. Tunnetusti tätäkin vastustetaan itsepintaisesti.

Uskonto ja elämänkatsomustieto pitäisi asettaa yhdenveroiseen asemaan ja irrottaa ne jäsenyyskysymyksistä. Oppiaineiden tulisi saada kilpailla oppilaista tarjontansa profiililla ja laadulla. Myös oppiaineiden nykyistä tiiviimpää ja pidemmälle menevää yhteistyötä olisi kannustettava. Tämä kuitenkin edellyttäisi muutoksia oppiaineiden opetussuunnitelmissa, jotta kaikille oppilaille voitaisiin taata riittävän yhdenmukainen opetus.

Oppiaineiden valinnaisuus mahdollistaisi uskonnon ja erityisesti elämänkatsomustiedon kehittämisen osittain uudelta pohjalta. Elämänkatsomustiedon 
keskeinen ongelma tällä hetkellä on oppiaineen pienuus. Joitakin kaupunkeja lukuun ottamatta aine on varsin marginaalinen. Oppiaine on kokonaisuutena niin pieni, ettei se varsinaisesti kehity, vaikka kehittämisen tarve olisi ilmeinen. Hyviä oppiaineen kehittämistä koskevia ajatuksia ei sinänsä puutu, mutta ei ole resursseja toteuttaa niitä. Ei ole olemassa kunnollisia oppikirjoja, koska niille ei ole kustantajia. Samasta syytä ei ole olemassa opettajan koulutuksen materiaaleja.

Koska oppiaine on pieni, sen kehittämisestä on pitkälle yksin vastuussa filosofian ja elämänkatsomustiedon opettajien järjestö. Feto on toiminut sinänsä erinomaisen aktiivisesti resurssiensa puitteissa. Oppiainetta on kehitetty myös melko pienellä joukolla, jonka näkemys oppiaineen luonteesta ja tavoitteista on jossain määrin rajoittunut ja yksipuolinen. Miten muuten voisi ollakaan, kun ottaa huomioon ne monenlaiset paineet ja odotukset, joita elämänkatsomustietoon on kohdistunut?

On siis hyvin ymmärrettävää, että oppiaineesta on käyty vain vähän laajempaa ja radikaalimpaa periaatekeskustelua. Enemmänkin on jatkettu kehitystyötä valitulla varsin kaidalla tiellä. Keskustelua pitäisi kuitenkin ehdottomasti käydä. Ainoa mahdollisuus kehittää oppiainetta ja rakentaa siitä todella kiinnostava vaihtoehto uskonnolle on selkiyttää ja myös laventaa oppiaineen tavoitteita ja katsomuksellisia sisältöjä nykyisestään.

\section{Katsomusaineiden kasvatustehtävistä}

Elämänkatsomustiedon opetus on nykyisellään tarkoitettu kirkkoon ja uskontokuntiin kuulumattomien oppilaiden joukolle, joka tunnetusti ei ole yhtenäinen katsomustaustaltaan. Tästä seuraa vaikea yhtälö: oppiaineen tulisi samanaikaisesti olla sekä katsomukselliselta sisällöltään riittävän väljä ja erilaisuutta suvaitseva, että samalla tavoitteiltaan, sisällöiltään ja työtavoiltaan riittävän johdonmukainen ja yhtenäinen. Jos se on liian väljä, se muuttuu epämääräiseksi; jos se on liian vahva, se syrjii joitakin ja karkottaa osan oppiaineesta periaatteessa kiinnostuneista.

Oppiaineen ratkaisu tähän dilemmaan on ollut tietopainotteisesti tulkittu ja uskontokriittisesti painottunut humanismi, jolle on annettu vain vähän konkreettista sisältöä. Sen sijaan, että puolustettaisiin jotakin ihmiskäsitystä ja arvomaailmaa, keskitytään ihmisoikeuksiin, tasa-arvoon, tieteelliseen rationaalisuuteen. Oppiaine kyllä sopii nykymuodossaan sen heterogeeniselle oppilasjoukolle, mutta on syytä kysyä, kuinka hyvin se itse asiassa täyttää kasvatukselliset tehtävänsä.

Ajattelen, että näitä kysymyksiä olisi aika lähestyä myös toisesta suunnasta, kysymällä nimenomaan oppiaineen kasvatuksellisia tavoitteita ja sisältöjä. 
Jos elämänkatsomustiedon kasvatustavoitteista olisi selkeämpi käsitys ja yksimielisyys, silloin olisi myös enemmän perusteita arvioida oppiaineen katsomuksellista profiilia ja erilaisten katsomuksellisten sisältöainesten osuutta ja paikkaa eri luokka-asteiden kursseilla. Näin ei nykyään nähdäkseni vielä ole.

Jotta tähän päästäisiin, elämänkatsomustiedon pitöisi kaivautua nykyisestä poterostaan, jossa se esiintyy sekulaarina vastineena tunnustukselliselle uskonnolle. Oppiaineitta pitäisi pohtia ja puolustaa nykyistä rohkeammin periaatteessa kaikille kiinnostavana vaihtoehtona, joka myöhäismodernissa yhteiskunnassa ja kulttuurissa voisi vastata oppilaiden monimuotoisiin katsomuksellisiin tarpeisiin selvästi paremmin kuin uskonto.

Elämänkatsomustiedossa sisältöjen ja työskentelytapojen tulisi viime kädessä perustua oppilaiden käytännöllisen identiteetin kehitystarpeisiin. Elämänkatsomustieto on identiteettiä rakentava tai sen rakentumista tukeva oppiaine, aivan kuten uskontokin. Tästä lähtökohdasta on helppo ymmärtää, miksi elämänkatsomustieto ei ole filosofiaa sen enempää kuin kulttuuriantropologiaa, psykologiaa, etiikkaa, kirjallisuutta, kulttuuritutkimusta, sosiologiaa tai estetiikkaakaan. Se ei ylipäätään voi perustua suoraan millekään tieteenalalle, koska se on käytännöllinen oppiaine. Näkemys siitä, minkälaisen kokonaisuuden oppiaine näistä monista aineksista kehittää, ei ole vielä riittävästi selkiytynyt.

\section{Miten katsomusaine rakentaa oppilaan identiteettiä?}

Keskeinen kysymys näin ajatellen kuuluu, miten ymmärtää oppilaiden käytännöllinen identiteetti ja miten koulun katsomusaineiden tulisi sen rakentumista tukea. Nimenomaan katsomusaineilla on koulussa tähän liittyvä erityistehtävä, koska muuten koulutyö on oppilaan näkökulmasta kovin pirstoutunutta ja yksipuolisen tietopainottunutta. Elämänkatsomustiedon opettajilla - kuten myös uskonnon opettajilla - pitäisi olla selkeä näkemys tästä asiasta, jotta he voisivat hahmottaa mitä oppiaineen kursseilla tulisi kulloinkin käsitellä, millä tavoin ja miksi.

Kuka minä olen? Miksi teen niitä asioita mitä teen? Mitä haluan? Mitä oikeastaan arvostan ja minkä vuoksi? Mitä tavoittelen, ihailen, mitä pyrin välttämään? Mitkä asiat ovat oman elämäni mielekkyyden lähteitä? Muun muassa nämä ovat käytännöllisen identiteetin kysymyksiä.

Käytännöllinen identiteetti on läsnä ja vaikuttaa itse kunkin tavoissa hahmottaa, jäsentää ja arvottaa asioita, tilanteita ja ihmisiä. Se on jotakin, mikä rakentuu vähitellen ja mistä itse kukin tulee tietoisemmaksi. Juuri käytännöllinen kannattelee henkilökohtaisen elämän jatkuvuutta, vaikka se muuttuukin hitaasti. Se on henkilökohtainen ja ainutkertainen sisällöiltään, vaikka se elää 
ja kehittyy erilaisten ihmissuhteiden varassa ja sisältää yleisiä rakenteita. Persoonallisuuden ja myös luonteen käsite voivat tavoittaa tästä ainakin osan.

Henkilökohtaisen elämänkatsomuksen rakentuminen on käytännöllistä identiteettityötä, mitä elämänkatsomustiedon opiskelu ryhmässä on. Lisäksi se on itse kunkin henkilökohtaisen työn tukemista. Elämänkatsomustiedon opetuksessa lähdetään alusta pitäen siitä, että itse kukin kasvaa yksilöksi osana erilaisia yhteisöllisiä perinteitä ja käytäntöjä. Tämä lähtökohta on tärkeä, ja siitä olisi pidettävä kiinni läpi luokka-asteiden. Toisaalta on selvää, että yksilöllisen identiteetin kannalta tärkeitä yhteisöllisiä käytäntöjä tulee eri vaiheissa käsitellä eri tavoin, edeten yhä käsitteellisempiin jäsennyksiin ja yhteisiä periaatekysymyksiä lisääntyvästi pohtien.

Luonnostelen seuraavassa lyhyesti ajatusmallin siitä, miten erilaisia tiedollisia ja katsomuksellisia sisältöjä voitaisiin elämänkatsomustiedon opetuksessa jäsentää siten, että ne kiinnittyisivät oppilaiden identiteetin kehittymisen kulloisiinkin tarpeisiin. Kyse on nähdäkseni siitä, miten elämänkatsomustiedon tiedolliset ja taidolliset sisällöt yhdistettäisiin kasvatukselliseen runkoon.

Malli muodostuu erottamalla toisistaan useamman tyyppisiä yksilöiden välisiä suhteita, joiden puitteissa itse kunkin käytännöllinen identiteetti käytännössä rakentuu. Filosofian ja sosiologian kielellä voidaan puhua myös yksilöiden välisen tunnustuksen (recognition, Anerkennung) muodoista, jotka kukin tavallaan rakentavat tai konstituoivat osapuolten identiteettiä.

En halua väittää, että itse kunkin yksilöllinen identiteetti olisi kokonaisuudessaan ihmissuhderakennelma, mutta kylläkin, että se suurelta osin rakentuu suhteissa. Olennaista tässä yhteydessä on se, että tämäntapaista jäsennystä seuraamalla voidaan paremmin hahmottaa, miten katsomusaineen kursseilla käsiteltävät erilaiset tiedolliset ja taidolliset sisällöt kytkeytyvät oppilaiden identiteetin kehittymiseen ja mikä on niiden katsomuksellinen merkitys.

Erotan seuraavassa kaikkiaan seitsemän yksilöiden välisten suhteiden tyyppiä, joita kutakin vastaa yksilön tietyntyyppinen suhde itseensä. Jäsennys etenee konkreettisesta abstraktiin, lähimpänä itseä olevista etäisempiin, tutuimmista vieraampiin. Ajatus kaikkiaan on, että jäsennyksen avulla voisi hahmottaa, miten katsomusopetuksessa samaan tapaan edeten erilaiset tiedollisen ja taidolliset kokonaisuudet kytkeytyvät oppilaiden kehittyvän identiteetin rakenteisiin. Sanomattakin on selvää, että jäsennys on vain yksi mahdollisista ja että sen perusajatus on yksityiskohtia tärkeämpi.

(1) Ensinnäkin ovat kaikkein läheisimmät suhteet omiin vanhempiin, sisaruksiin, myöhemmin ystäviin, rakastettuihin. Nämä suhteet ovat varsin tunnevaltaisia ja niissä kehittyvät itse kunkin valmiudet tuntea rakkautta ja luottamusta toisia ja samalla itseä kohtaan. Ne koskevat yksilöä kokonaisuutena, ei vain jotakin puolta tai ominaisuutta. Yleinen näkemys lienee, että tämä lähisuhteissa muodostuvat emotionaalinen kerrostuma on yksi- 
lön identiteetin eräänlainen ydin, jonka ympärille kerrostumat rakentuvat. Jos se on särkynyt tai liian heikko, koko rakennelma horjuu. Se on ydin, jota kussakin oppilaassa tulisi vaalia, pyrkiä vahvistamaan ja joskus myös paikkaamaan.

Ala-asteen ensimmäisillä kursseilla katsomusaineissa liikutaan aihepiireissä, jotka painottuvat näihin lähisuhteisiin. Käsitellään pääosin varsin konkreettisia ihmissuhteita ja niihin liittyviä tapoja, käytäntöjä, perinteitä ja merkityksiä. Olisi kuitenkin tärkeää, että näitä teemoja käsitellään myös myöhemmillä kursseilla, joskin erilaisista näkökulmista. Siten oppilaille alkaa hahmottua, miten tärkeitä nämä lähisuhteet ovat muiden ihmissuhteiden kannalta.

(2) Toiseksi on yksilöiden suhteita, jotka painottuvat harrastuksiin, vapaa-aikaan, yhdessäoloon kavereiden kanssa. Näissä suhteissa toisiin ja samalla itseen kehittyy kyky tunnistaa omaa erityislaatua, yksilöllisyyttä, samoin kuin kyky samaistua toisiin ja erottautua toisista omana itsenään. Näissä suhteissa on pitkälle kyse siitä, minkälainen toinen on ja itse on. Itseä peilataan toiseen ja toisiin tekemällä jotakin, pyrkimällä näyttämään omaa osaamistaan.

Elämänkatsomustiedossa näitä kaverisuhteita ja niiden rikkaita kulttuurisia sisältöjä käsitellään siitä näkökulmasta, miten itse kukin yksilönä rakentuu niiden kautta hakien toisten hyväksyntää ja samalla opetellen tunnistamaan sekä hyväksymään omaa erityisyyttään. Suvaitsevaisuuden kysymysten käsittely kuuluu tälle alueelle, mutta ne ovat toki tärkeitä myös muissa ihmissuhteissa.

(3) Kolmanneksi on yksilöiden suhteita, jotka liittyvät erilaisiin työtehtäviin ja yhteiskunnallisiin rooleihin. Koulunkäynti ja sen puitteissa muodostuvat erilaiset suhteet oppilastovereihin ja opettajiin ovat harjaantumista tuleviin ihmissuhteisiin ja vastaaviin itsesuhteisiin työelämässä. Näissä edellisiä etäisemmissä, vakiintuneiden sääntöjen, roolien ja instituutioiden hallitsemissa suhteissa itse kukin pyrkii löytämään tapansa toteuttaa itseään. Samalla itse kunkin pitäisi oppia arvostamaan itseään ja myös toisia siihen liittyen, miten suoriutuu näistä yhteisistä velvoitteista.

Elämänkatsomustiedon kursseilla työhön liittyviä erilaisia yhteiskunnallisia käytäntöjä ja instituutioita tulisi tarkastella nimenomaan siitä peruskysymyksestä käsin, miten nuoret oppivat hahmottamaan niiden luonnetta ja merkitystä oman erityisyyden tunnistamisen ja itsetoteutuksen kannalta.

(4) Edelleen on yksilöiden välisiä suhteita ja vastaavasti itsesuhteita, jotka liittyvät yhteiskunnan oikeudellisiin ja hallinnollisiin normijärjestelmiin 
sekä instituutioihin. Näissä suhteissa jokaiselta edellytetään kykyä hahmottaa itseä ja toisia yhdenveroisina oikeuspersoonina, joilla on oikeuksia ja velvollisuuksia.

Katsomusaineiden kursseilla käsitellään myös näiden suhteiden luonnetta, mutta jälleen nimenomaan keskittyen niitä vastaavaan käytännöllisen identiteetin ulottuvuuteen. Näiden huomattavasti edellisiä abstraktimpien, oikeuspersoonaa ja juridisia oikeuksia ja velvollisuuksia koskevien kysymysten käsittely painottuu ylempiin luokka-asteisiin.

(5) Viidenneksi on yksilöiden välisiä suhteita, jotka liittyvät yhteiskunnan poliittiseen järjestelmään ja kansalaisuuteen. Myös elämänkatsomustiedon kursseilla olisi tärkeää pohtia, mitä merkitystä itse kunkin kannalta identiteetin kannalta on osallistumisella yhteisten asioiden hoitoon, vaikuttamisella asioihin ja poliittisella julkisuudella.

Vaikka poliittiset instituutiot ja liikkeet eivät sinänsä ole oppiaineen keskeistä sisältöä, niin se, että oppilaat alkavat hahmottaa itsensä ja toisensa kansalaisina, jotka ottavat vastuuta ja huolehtivat toisistaan, on aivan olennaista. Muun muassa myötätunnon ja solidaarisuuden kysymykset, eikä vain toisia ihmisiä vaan myös luontoa ja erityisesti eläimiä koskien, kuuluvat tähän yhteyteen.

(6) Kuudenneksi on yksilöiden välisiä suhteita ja vastaavia itsesuhteita, jotka liittyvät moraaliin yhteiskunnallisena instituutiona sekä yksilöllisenä rakenteena. Itse kunkin käytännöllisen identiteetin kehittymisen kannalta moraaliset suhteet toisiin ja itseen ovat olennaisen tärkeitä, koska niissä kasvaa kyky kunnioittaa itseä ja toisia yhdenveroisina persoonina. Elämänkatsomustieto ei kuitenkaan ole filosofista etiikkaa, jossa tulisi keskittyä päätoimisesti pohtimaan yksilöiden välisiä moraalisia suhteita. Tärkeää kuitenkin olisi, että oppilaat oivaltaisivat moraalisten suhteiden tärkeyden oman identiteetin kokonaisuuden kannalta.

(7) Lopulta seitsemänneksi itse kukin pohtii yksin ja yhdessä toisten kanssa elämän suuria merkitys- ja tarkoituskysymyksiä, perimmäisiä arvoja, elämän arvokkuuden ja mielekkyyden lähteitä. Nämä ovat varsinaisia katsomuskysymyksiä sanan perinteisessä merkityksessä. Se, joka uskoo jumalaan, jäsentää näitä kysymyksiä eri tavalla kuin se, joka ei usko. Jokainen kuitenkin pohtii näitä kysymyksiä. Niiden kautta omaa ja toisten elämää opitaan hahmottamaan laajemmasta näkökulmasta sekä kohtaamaan oman itsen äärellisyys, kuolema.

On selvää, että elämänkatsomustiedon kursseilla näitä katsomuskysymyksiä tulisi pohtia jatkuvasti ja edeten niitä koskeviin yhä käsitteellisempiin ja 
periaatteellisempiin jäsennyksiin. Suvaitsevaisuus on tärkeä teema myös tällä alueella. Kuten edellä totesin, näillä kysymyksillä ei kuitenkaan ole yhtä keskeistä asemaa elämänkatsomustiedossa kuin on nykyään uskonnossa, jossa kaikki katsomukselliset kysymykset viime kädessä perustetaan suureen teistiseen kertomukseen. Myös elämänkatsomustiedossa näitä kysymyksiä pitäisi käsitellä siten, että ne koskettavat oppilaiden käytännöllistä identiteettiä sitä kuitenkaan loukkaamatta.

Esittämäni luonnos on vain yksi mahdollinen hahmotus. Muitakin ihmissuhteiden ja itsesuhteiden tyyppejä olisi mahdollista erottaa, ja edellä esiteltyjä voitaisiin luonnehtia toisin tai yksityiskohtaisemmin kuin olen tehnyt. Olennaista mielestäni on nähdä, miten oppilaiden käytännöllinen identiteetti, jonka rakentumista elämänkatsomustiedossa on tarkoitus osalta tukea ja edistää, suureksi osaksi muodostuu tällaisista maailmasuhteiden, ihmissuhteiden ja vastaavien itsesuhteiden kerrostumista.

Tällaisen hahmotuksen pohjalta voisi olla mahdollista suunnitella katsomusaineiden kursseille kasvatuksellisia tavoitteita sekä hahmottaa konkreettisesti vastaavia tiedollisia sisältöjä, jotka muodostavat jäsentyneen ja perusteltavissa olevan kokonaisuuden. Tällöin opettajilla, oppimateriaalien laatijoilla ja opetussuunnitelmia tekevillä voisi olla hallussaan nykyistä selkeämpi ja laaja-alaisempi näkemys siitä, miten opetus etenee luokka-asteelta toiselle, miksi se etenee niin kuin se etenee sekä minkälaisia tavoitteita ja sisältöalueita kulloinkin tulisi toteuttaa.

Elämänkatsomustiedon opiskelun pitäisi tarjota oppilaille käytännöllisen identiteetin rakentumisen kannalta välttämättömiä tietoja ja taitoja, ja samalla antaa heille yksilöinä tilaa sekä välineitä tehdä työtä itsensä kanssa. Tämä elämänkatsomustiedon opetuksen omakohtaisuus ei saisi merkitä kurssien pirstaleisuutta. Edellä esitetyn hahmotuksen avulla tätä voisi torjua.

Omakohtaisuus ei myöskään saisi merkitä sitä, että oppiaineessa tunkeudutaan oppilaiden yksityisyyden alueelle ja rikotaan heidän henkilökohtaisen koskemattomuutensa rajoja. Selkeiden kasvatuksellisten tavoitteiden omaksumisen ei pitäisi tarkoittaa, että oppilaiden identiteetin ydinkysymysten käsittely olisi heidän kannaltaan ahdistavaa ja painostavaa. Tämä lienee erityinen ongelma uskonnossa.

Elämänkatsomustiedon kurssien pitäisi jäsentyä tiedollisiksi sisällöiksi, joissa käsitellään oppilaiden käytännöllisen identiteetin rakentumisen kannalta keskeisten tunnustussuhteiden alueita. Sisältöalueiden tulisi muuttua vähitellen käsitteellisemmiksi ylemmille luokka-asteille edettäessä ja kertautua sekä syvetä luontevassa rytmissä. Elämänkatsomustiedon uudet opetussuunnitelman perusteet ovat nähdäkseni varsin hyvät niin peruskoulussa kuin lukiossa. Lähinnä ongelmaksi voi muodostua kurssikokonaisuuden hajanaisuus, jopa pirstaleisuus. 
Edellä luonnostelemani kaltaisen jäsennyksen pohjalta kokonaisuuteen olisi ehkä mahdollista saada lisää yhtenäisyyttä, johdonmukaisuutta ja syvyyttä. Tämäntapaiselta pohjalta voisi periaatteessa hahmottaa myös uskonnon opetuksen etenemistä luokka-asteelta toiselle. Jos näin tehtäisiin, silloin voitaisiin ehkä myös nähdä, missä mielessä uskonnon ja elämänkatsomustiedon tavoitteet ja sisällöt ovat yhteismitallisia, missä taas eivät. Syntyisi ehkä myös enemmän sellaista yhteistä, jonka varassa oppiaineiden kurssit voisivat luontevasti olla vaihtoehtoisia ja oppilaiden vapaasti valittavissa. Siten voitaisiin päästä lähemmäs ihannetta, josta vielä nyt ollaan kovin kaukana. 



\title{
Elämänkatsomustiedon kehkeytyminen
}

\author{
Eero Salmenkivi, Pekka Elo, Tuukka Tomperi \\ \& Tuulia Ahola-Luttila
}

Tiivistelmä

Elämänkatsomuksen vapaa ja itsenäinen luominen, omaksuminen ja viljeleminen on jokaisen yksilön luovuttamaton ihmisoikeus. Yhteiskunnan ja julkisen vallan tehtävänä on saada aikaan tämän oikeuden toteutumiselle mahdollisimman hyvät lainsäädännölliset, opetukselliset, taloudelliset ja kulttuuriset olosuhteet. Suomessa uskonnon ja omantunnonvapaus taataan perustuslain 11 pykälässä. Tätä vapautta tulee noudattaa myös koulujen katsomusopetuksessa. Elämänkatsomustiedon kehkeytymisessä on pitkälti kysymys näiden ihmisoikeuksien toteutumisesta Suomen yleissivistävässä koululaitoksessa.

Tässä artikkelissa kuvataan uskonnonvapauden kehittymistä Suomessa erityisesti koulun uskontoa korvaavan oppiaineen näkökulmasta. Jo Suomen itsenäisyyden alkuvuosina lainsäädännöllä asetetun uskonnonvapauden toteutuminen on kouluopetuksessa ollut varsin vaikeaa. Ratkaisevana tekijänä uskonnonvapauden toteutumisessa voi näiltä osin pitää elämänkatsomustiedon tulemista suomalaisen yleissivistävän koulun oppiaineeksi vuonna 1985. Artikkelissa tarkastellaan myös, millainen oppiaine elämänkatsomustieto on ja miten se on kehittynyt vuoden 1985 jälkeen. Lopuksi esitetään joitain näkökohtia katsomusopetuksen tulevista kehitysmahdollisuuksista.

Avainsanat:elämänkatsomus, historia, lainsäädäntö, lukiokoulutus, opetussuunnitelma, perusopetus, uskonnonvapaus

\section{Vaatimus uskonnonvapaudesta}

Yksimielisyys uskonnossa ja oikeassa jumalanpalveluksessa ovat arvollisen, sopuisan ja pysyvän hallituksen vahvin perusta - näin todettiin vuoden 1634 Ruotsin hallitusmuodossa. Sama lausuma toistui sittemmin kaikissa hallitusmuodoissa aina Suomen itsenäistymiseen asti. Oikeauskoinen kristillinen valtio "ei ainoastaan huolehtinut ihmisten välisistä suhteista, vaan myös ihmisten suhteista kristinuskon Jumalaan”. (Elo 1992, 9.) Tämä käsitys periytyi kato- 
lisesta oikeudesta luterilaisten valtioiden kirkkosuhteen järjestämiseen. Näin myös Ruotsin valtion tehtävänä ei ollut vastata ainoastaan kansalaisten aineellisesta menestyksestä, vaan myös kansalaisten sielujen autuudesta. (Elo 1992, 9-10.)

Manner-Euroopan valistusajattelussa kehittyi 1700-luvulla uskontokritiikin perinne, joka hitaasti mutta varmasti vaikutti uskonnon ja kirkon yhteiskunnalliseen rooliin. Valistuksessa otettiin etäisyyttä hengellisistä auktoriteeteista ja ilmoituksellisesta kristinuskosta. 1600- ja 1700-luvun libertiinit ja deistit kyseenalaistivat uskonnon kirkolliset, ilmoitukselliset ja taikauskoiset elementit ja etsivät järjen, luonnon ja tieteen kanssa sopusointuista uskontoa, joka olisi yhteinen kaikille. 1700-luvun loppupuolen skeptikot ja ateistit menivät vielä pidemmälle ja halusivat kirkon vallan ohella torjua myös uskonnollisen uskon otteen ihmisistä. (Baumer 1977, 182-200; Kaitaro 2003, 289-298.)

Kuten aatteissa, myös reaalipolitiikassa Ranska oli muutoksen etulinjassa. Eräänlaisena jatkeena paavin ja monarkin kauan kestäneelle keskinäiselle valtakamppailulle katolinen kirkko alistettiin lopulta Ranskan vallankumouksessa valtion valvontaan. Samalla sen valtaa heikennettiin poistamalla kirkon aiempia etuoikeuksia. Valtion sanoutuessa irti yhden uskonnon suosimisesta avautui mahdollisuus yksilöiden uskonnonvapaudelle. Niinpä uskonnonvapauden valtiollinen idea lausuttiin julki vallankumouksen hengessä Ranskassa vuonna 1789 annetussa Ihmisoikeuksien julistuksessa: "Ketään ei saa häiritä mielipiteidensä tähden, edes uskonnollisten, kunhan niiden ilmaiseminen ei häiritse lain määräämää julkista järjestystä" (Déclaration des Droits de l'homme et du citoyen du 26 août 1789; § 10). Vain hieman tämän jälkeen uskonnonvapaus sisällytettiin selkein sanoin Yhdysvaltain perustuslain lisäyksiin. (Ks. esim. Baumer 1977, 182-200; Haarscher; 2006 Porter 1990.)

Uskonnonvapautta koskien valistus tavoitti Suomen sivistyneistön vajaa sata vuotta myöhemmin. 1800-luvun loppupuoliskolla vapaamielinen lehdistö alkoi herättää keskustelua kristinuskon ja luterilaisen kirkon asemasta sekä myös uskonnon opetuksen pakollisuudesta. Viktor Heikel ja Minna Canth sekä eräät muut olivat vuonna 1887 perustamassa järjestöä, jonka nimeksi suunniteltiin otettavan Yhdistys Uskonnonvapautta ja Suvaitsevuutta Varten. Senaatti hylkäsi yhdistyksen toiminta-anomuksen eikä vuonna 1889 hyväksytyllä eriuskolaislailla ollut juuri merkitystä, koska se salli vain protestanttisten vähemmistöjen järjestäytymisen eikä sallinut kirkosta eroamista. Uskonnonvapautta vaati myös vuonna 1905 perustettu vapaamielisen sivistyneistön opiskelijayhdistys Prometheus. Sen kantavia voimia olivat Edvard Westermarck (pj.), Rolf Lagerborg, Georg Schauman, Wilhelm Bolin, Yrjö Hirn, Rafael Karstén, Viktor Heikel, Alma Söderhjelm, Hjalmar Eklund ja Ernst Lampén. Yhdistys oli kiinnostunut koulujen katsomuksellisesta opetuksesta. Vuonna 1906 se lähetti kannanoton koulujen uskonnon opetuksesta koulukomitealle sekä Helsingin 
yliopiston konsistorille. Kannanotossa ehdotettiin tunnustuksellisesta uskonto-opetuksesta luopumista sekä kaikille pakollisena ylioppilastutkintoon kuuluvan evankelis-luterilaisen oppikuulustelun poistamista. (Elo 1992; Luoma 1967; Pikkusaari 1998, 19-; Seppo 1992, 12; 2003, 39.)

Poliittisessa kentässä Suomen Sosialidemokraattinen puolue vaati uskonnonvapautta ja otti vuoden 1903 Forssan kokouksessa ohjelmaansa kirkon erottamisen valtiosta. Vuoden 1905 suurlakko johti eduskuntauudistukseen ja se papiston suoran vaikutusvallan romahdukseen valtiopäiväsäätynä. Vuonna 1906 asetettiin uskonnonvapauskomitea, jonka tehtävänä oli siviilivihkimyskysymyksen selvittäminen ja uskonnonvapauslain valmistelu. (Brotherus 1923; Elo 1992; Pikkusaari 1998; Reijonen 1977, 32-41; Seppo 1992, 13.)

\section{Omantunnonvapaus itsenäistymisen myötä}

Uskonnonvapauspyrkimykset autonomisessa Suomessa raukesivat tsaristisen Venäjän vastustukseen. Helmikuussa vuonna 1917 tapahtui Venäjällä maaliskuun vallankumous. Venäjän väliaikainen hallitus vahvisti maaliskuun lopulla Tokoin senaatin kokoonpanon, ja senaatti asetti uuden uskonnonvapauskomitean, jonka puheenjohtajaksi kutsuttiin edellisen komitean sihteeri K. R. Brotherus. Se sai mietintönsä valmiiksi joulukuussa kaksi päivää ennen itsenäisyysjulistusta. (Elo 1992, 10.)

Vuoden 1917 uskonnonvapauskomitean enemmistö asettui kannattamaan tunnustuksetonta uskonnon opetusta ja sen rinnalla (tai yhteydessä) siveysopin opetusta. Komitean mielestä tunnustuksettomankaan uskonnon ja siveysopin opetuksen ei tulisi olla pakollista, vaan siitä oli sallittava vapautus omantunnonsyistä. Mietinnössään komitea totesi ainoastaan uskonnon opetuksen tunnustuksettomuuden jättäen tarkemmat säännökset koululakeihin. Ehdotuksen mukaan oppilas olisi vapautettava opetuksesta huolimatta opetuksen tunnustuksettomuudesta, mikäli holhooja ei toivonut oppilaan siihen osallistuvan ja mikäli hän selvitti lapsen saavan muualla vastaavaa opetusta. (Elo 1992, 10-11; Reijonen 1977, 42-52.)

Tästä asetelmasta, mutta muuttuneessa yhteiskunnallisessa tilanteessa, keskustelu jatkui kansalaissodan jälkeen. Juridisesti tilanne oli perustavasti muuttunut, sillä vuoden 1919 uuden hallitusmuodon pohjalta Suomen kansalaisille kuului uskonnonvapaus. Silti hallitus päätyi loppujen lopuksi koulun uskonnon opetuksen osalta komitean mietintöä varovaisemmalle linjalle, kirkolliskokouksen lausuntoa myötäillen. Uskonnon opetuksen tunnustuksellisuus palautettiin lakiesitykseen. Itsenäisen Suomen eduskunta hyväksyi keväällä 1921 hallituksen esityksen uskonnonvapauslaiksi. Se äänestettiin lepäämään 
yli vaalien. Laki hyväksyttiin lopullisesti vuonna 1922, ja se tuli voimaan seuraavan vuoden alusta. (Elo 1992; Scheinin 1995, 132; Seppo 2003, 40.)

Uskonnonvapauslaissa puhutaan koulujen tunnustuksellisesta uskonnon opetuksesta ehdollisena. Uskonnonvapauslain ${ }^{1} 8$ §:ssä säädettiin:

Jos uskonnon opetusta valtion tai kunnan ylläpitämässä tai avustamassa kansakoulussa, oppikoulussa tai muussa oppilaitoksessa annetaan jonkun uskontokunnan opin mukaan, on oppilas, joka kuuluu toiseen uskontokuntaan tai joka ei kuulu mihinkään uskontokuntaan, edusmiehen vaatimuksesta vapautettava sellaisesta uskonnon opetuksesta. (Elo 1992, 11; Reijonen 1977, 59-66.)

\section{Kansakoululaki: Uskonnon historia ja siveysoppi}

Vuoden 1921 alussa sai kouluhallituksen ylijohtaja Mikael Soininen tehtäväkseen valmistella lain kansakouluopetuksen perustaksi. Ehdotuksen pohjalta kouluhallitus esitti kansakouluun oppilaiden enemmistön tunnustuksen mukaista uskonnon opetusta, kaikille pakollista siveysopin opetusta sekä koulun uskonnon opetuksesta vapautetuille oppilaille uskonnon historian opetusta. Samansisältöisen esityksen hallitus antoi eduskunnalle, jossa sivistysvaliokunnan puheenjohtajana toimi Mikael Soininen. Sivistysvaliokunta yhtyi kouluhallituksen ja valtioneuvoston kantaan lisäten kuitenkin tarkennuksen, että siveysopetuksen sisältö ei saanut poiketa yleisesti hyväksytyistä siveellisistä periaatteista sellaisina kuin ne yhtäpitävästi ilmenevät sekä tieteellisessä tutkimuksessa että Uudessa testamentissa. Ratkaisu siirtyi kuitenkin kesän 1922 eduskuntavaalien yli. (Elo 1992, 11.)

Kevättalvella 1922 kirkolliset piirit olivat alkaneet aktivoitua lakiehdotusta vastaan ja vastustus kirjattiin "kirkkokansan ohjelmaksi" nimettyyn julkilausumaan. Siveysoppi nousi tärkeäksi teemaksi, koska sen epäiltiin edistävän uskonnon opetuksen poistamista opetussuunnitelmasta. Todettiin, että kristilliseltä kannalta siveysopetuksen tuli olla kristillistä ja kristinuskon opetuksen siveellistä. Keskustelu sävytti kesän eduskuntavaaleja. Puolueet kuitenkin joko välttivät ottamasta vahvaa virallista kantaa siveysoppiin tai ilmoittivat tukevansa perinteistä uskonnon opetusta ja avoimesti vastustivat kaikille yhteistä siveysoppia. Eduskunnassa vasemmisto kannatti uskonnon opetuksen poistamista koulusta kokonaan ja sai oikeiston liberaaleja edustajia puolelleen. Vähäisellä ääntenenemmistöllä uskonnon opetus kuitenkin säilytettiin. Sen jälkeen vasemmisto katsoi paremmaksi taktikoida kannattamalla tunnustuksellista uskonnon opetusta kirkkoon kuuluville ja siitä vapautetuille siveysopin opetusta. Riskinä pidettiin sitä, että tunnustuksettomaksi määritelty uskonnon

Lainsäädännöstä ja sen valmistelusta yleisesti on lähteenä käytetty Valtion säädöstietopankkia (Finlex). 
opetus voitaisiin esittää kaikille oppilaille pakolliseksi ja antaa sen varjolla käytännössä tunnustuksellista opetusta myös kirkkoon kuulumattomille. Yhteiselle siveysopin opetukselle ei lopulta löytynyt vahvaa puoltajaa. (Elo 1992, 11; Elo \& Linnankivi 1995, 120; Hämäläinen 2003, 57-83.)

Syyskuussa 1922 valtioneuvosto antoi uuden esityksen kansakoulun järjestysmuodon perusteita koskevaksi laiksi. Siinä siveysoppi oli tarkoitettu vain koulun uskonnon opetuksesta vapautetuille oppilaille, kun taas muille siveysoppi olisi ollut vapaaehtoinen oppiaine. Eduskunnan sivistysvaliokunta poisti mahdollisuuden opettaa siveysoppia oppilaalle vapaaehtoisena oppiaineena sekä lisäsi oppiaineen nimeen uskonnon historian. Oppiaineen nimeksi tuli siis uskonnon historia ja siveysoppi. Tässä muodossa laki vahvistettiin 18.5.1923. Näin Suomessa oli luotu perusrakenne, jonka pohjalta katsomusopetus järjestetään vielä 2000-luvullakin. (Elo 1992; Hämäläinen 2003; Pikkusaari 1998, 130-137; Saine 2000, 64-75.)

\section{Opetussuunnitelmat ja opetus}

Vuodesta 1918 Soinisen johdolla työskennellyt opetussuunnitelmakomitea valmisteli myös uskonnon historian ja siveysopin opetussuunnitelman. Toteutunut opetus oli erittäin vähäistä ja siinä noudateltiin väljästi komitean asettamia suuntaviivoja. Esimerkiksi lukuvuonna 1930-1931 oppiainetta opiskeli koko maassa 80 oppilasta ja 1940-luvun alussa suurimmissa kaupungeissa oli yhteensä muutamia kymmeniä oppilaita. Opetukseen osallistui siis vain marginaalinen määrä kaikista oppilaista, jotka uskonnonvapauslain nojalla olivat oikeutettuja uskonnon opetuksesta vapauttamiseen. Viikkotuntimääräksi oli määritelty vähintään yksi, kun taas uskontoa opetettiin keskimäärin 3-4 viikkotuntia. Opetusta oli vain kansakoulussa, sillä oppikoulua koskeviin lakeihin ei kuulunut mainintaa korvaavasta opetuksesta uskonnon opetuksesta vapautetuille oppilaille. Lukusuunnitelmat määrittäneissä asetuksissa oli tosin kirjattuna oppiainenimike uskonnon historia ja siveysoppi, mutta luultavasti opetusta ei tarjottu missään. (Elo 1992, 11-12; Kähkönen 1976, 109-110; Saine 2000, 104-107; Tamminen 1967, 141-143.)

Otava julkaisi oppiaineeseen J. O. Metsikön kirjoittamat oppikirjat: vuonna 1936 Kasva hyväksi ja vuonna 1938 Uskontoa ennen ja nyt. Metsikkö oli julkaissut parikymmentä vuotta aiemmin teoksen Muutamia mietteitä kansakoulun uskonnon opetuksesta (1913). Tässä teoksessa hän toisaalta puolusti koulun kasvatuksellista uskonnon opetusta myös toisenlaisen uskonnollisen katsomuksen omaaville (Metsikkö 1913, 23-24). Toisaalta hän määritteli, että uskonnon opetuksen tarkoitus "on herättää ja ravita uskonnollista elämää, elämää Jumalan yhteydessä” (Metsikkö 1913, 24). Täten ei ole ihme, että myös 
uskonnon historian ja siveysopin oppikirjat olivat selkeästi uskonnollisia ja nimenomaan kristillisiä. Oppikirjan esipuheessa todetaan, että "syventyvä uskonnollisten asiain käsitys ja avarampi sen alan näkemys ovat osaltaan apuna ymmärtääksemme eri oloissa ja eri aikoina eläneiden ihmisten uskonnollista etsintää ja myös lähentyäksemme kristillisen rakkauden korkeata päämäärää" (Metsikkö 1959, 8). Kristinuskon painotusta esipuheessa puolustettiin toisaalta kotiseutuperiaatteella, toisaalta sillä, että "Uuden testamentin esitys samalla on varsin lastentajuista, kun sen sijaan monen muun uskonnon peruskirjan teksti on lapsille varsin vaikeata" (Metsikkö 1959, 5; ks. Tamminen 1967, 142).

Kansakoulun opetussuunnitelmakomitea (KM 1952:3) määritteli uskonnon historian ja siveysopin uuden opetussuunnitelman, jonka laadinnassa komitea oli käyttänyt Metsikön asiantuntemusta. Opetussuunnitelma noudatteli sisällöllisesti Metsikön parikymmentä vuotta aiemmin kirjoittamia oppikirjoja. Komitean mukaan opetuksen oli avarrettava oppilaiden henkistä näköpiiriä perehdyttämällä heitä niihin uskonnollisen elämän muotoihin ja arvoihin, joita meille läheiset tai muuten sivistyselämäämme huomattavasti vaikuttaneet uskonnot sisältävät. Lisäksi oli herätettävä oppilaiden ymmärtämystä erilaisten uskonnollisten katsomusten omaksuneita kohtaan toisaalta osoittamalla, että uskonnollisella etsinnällä on yhteinen inhimillinen pohja eri aikoina ja eri paikoissa sekä toisaalta näyttämällä, mitkä syyt ovat vaikuttaneet uskontojen erilaisuuteen. Vaikka suvaitsevaisuutta voi pitää uutena korostuksena, opetuksen oli Metsikön oppikirjojen tapaan tarkoitus olla selvästi uskontokeskeistä: eiuskontoisia elämänkatsomuksia ei ollut olemassa. (Elo 1992, 12; Saine 2000, 104-106; Tamminen 1967, 143.)

Vuoden 1957 kansakoululaissa oppiaineen nimi muutettiin uskontojen historiaksi ja siveysopiksi, ja opetuksen järjestämisvelvoitteeksi määriteltiin viisi opetukseen osallistuvaa oppilasta. Aikaisemmin vähimmäismäärä oli jätetty määrittelemättä, jolloin periaatteessa yksikin oppilas olisi ollut oppiaineeseen oikeutettu. Opetuksessa tuli käyttöön Otavan vuonna 1965 julkaisema oppikirja Oikein vai väärin, jonka olivat kirjoittaneet Ritva Nevalainen ja Sisko Kiuru. (Elo \& al. 1992; Saine 2000, 106-107.)

\section{Uskontojen historia ja siveysoppi peruskoulussa}

Helmikuun 6. päivänä 1964 asetetun Peruskoulukomitean puheenjohtajaksi valtioneuvosto kutsui kouluhallituksen pääjohtajan R. H. Oittisen. Komitea päätyi esittämään peruskoulun oppiaineluetteloon uskontoa, uskontojen historiaa ja siveysoppia (KM 1965:A7).

Huhtikuussa 1967 hallitus antoi eduskunnalle esityksen laiksi koulujärjestelmän perusteista, joka noudatteli peruskoulukomitean kantaa esittämällä yh- 
teisten oppiaineiden luetteloon siveysoppia. Lakiesityksen 6 §:n 3 momentissa säädettiin uskonnon opetuksesta vapautetuille oppilaille opetettavaksi uskontojen historiaa mainitsematta erikseen, millä perusteella oppilaat oli uskonnon opetuksesta vapautettu. Kun kiista itsenäisestä siveysopin opetuksesta olisi saattanut viivästyttää peruskoulun puitelain hyväksymistä, päätyi eduskunnan sivistysvaliokunta esittämään entisestä kansakoulusta tuttua mallia, jossa siveysoppi oli yhdistetty uskonnon historian opetukseen. Eduskunnan suuri valiokunta tarkensi vielä uskonnon opetuksesta vapauttamista maininnalla uskonnonvapauslain nojalla. Muutoin lakia olisi saatettu tulkita siten, että kaikilla oppilailla riippumatta heidän jäsenyydestään uskonnollisissa järjestöissä olisi ollut oikeus osallistua uskonnon opetukselle vaihtoehtoiseen opetukseen. (Elo 1992, 12; Saine 2000, 137.)

Vuonna 1966 asetetun Peruskoulun opetussuunnitelmakomitean tehtävänä oli uudistaa opetussuunnitelmat vastaamaan uutta lainsäädäntöä. Komitea pyysi asiantuntijalausunnot uskontojen historian ja siveysopin opetussuunnitelmasta uskontotieteen professori Lauri Hongolta ja kansakoulunopettaja Eino Keskiseltä. Komiteamietinnössä opetussuunnitelman tavoitteet jaettiin uskontojen historian ja siveysopin aihealueiden kesken. Uskontojen historian opetuksen oli tarkoitus perehdyttää oppilas omaan uskonnolliseen traditioomme sekä muihin uskontoihin, ohjata oppilasta ymmärtämään uskonnollisia vakaumuksia ja maailmankatsomuksia sekä ohjata oppilasta arvostamaan omaa sivistysperintöämme sekä uskonnon osuutta siinä. Siveysopin opetuksen tavoitteena oli mm. edistää yhteisön elämää tukevia hyveitä, perehdyttää yhteisön kannalta välttämättömiin sääntöihin, antaa tietoa ihmisoikeuksista, edistää eettisten periaatteiden toteutumista koulussa, antaa tietoa eri uskontojen tavoista ratkaista eettisiä ongelmia sekä analysoida ajankohtaisia tiedonvälityksessä uutisoituja tapahtumia, joiden ymmärtäminen edellyttää uskonnollisen miljöön ja etiikan tuntemusta. (KM 1970: A5, 265-.)

Komitean laatima uskontojen historian ja siveysopin opetussuunnitelma herätti kriittisen keskustelun, jossa arvosteltiin opetussuunnitelman tunnustuksellisuutta. Tilannetta parantamaan kouluhallitus asetti vuonna 1972 työryhmän laatimaan opettajan opasta, jossa ohjattaisiin oppiaineksen valintaa vähemmän tunnustukselliseksi. Oppaasta saatujen arvioiden takia ylitarkastaja Jaakko Linnankivi, joka oli ollut Peruskoulun opetussuunnitelmakomitean jäsen, esitti kouluhallitukselle työryhmän asettamista, jonka tehtävinä olisivat olleet seuraavat: ehdotuksen laatiminen uudeksi opetussuunnitelmaksi, laaditun opettajan oppaan tarkistaminen vastaamaan uutta opetussuunnitelmaa sekä peruskoulussa alkaneen opetuksen jatkomahdollisuuksien selvittäminen.

Vapaa-ajattelijain liiton pääsihteeri Erkki Hartikainen teki vuonna 1978 kantelun Yhdistyneitten Kansakuntien ihmisoikeuskomitealle peruskoulun opetussuunnitelman mukaisesta uskontojen historian ja siveysopin opetukses- 
ta (Scheinin 1995, 136-137). Sen siivittämänä uudistukset saivat vauhtia (Elo 1992, 13).

\section{Vuoden 1981 oppimäärä²}

Kouluhallitus asetti vuoden 1979 alussa työryhmän (myöhemmin UH-työryhmä) laatimaan uutta uskontojen historian ja siveysopin opetussuunnitelmaa. Työryhmään kutsuttiin puheenjohtajaksi suunnittelupäällikkö Heikki Lampi ja jäseniksi lääninkouluneuvos Olavi Ketonen ja ylitarkastaja Jaakko Linnankivi sekä sihteereiksi opettajat Raimo S. Wallin ja Pekka Elo. Työryhmä sai tammikuussa 1980 valmiiksi ensimmäisen uskontojen historian ja siveysopin oppimääräluonnoksen. Siinä oppiaines oli ryhmitelty neljäksi tavoitekokonaisuudeksi, joilla pyrittiin selkeyttämään sisältöjen tarkastelunäkökulmaa:

1. Kasvatus eettisesti oikein toimiviin ihmissuhteisiin.

2. Kasvatus yhteisölliseen ja yhteiskunnalliseen tietoisuuteen, vastuuntuntoon ja toimintaan.

3. Kasvatus ymmärtämään oman kansamme kulttuuriperintöä sekä nykyistä kulttuuriamme, erityisesti maailmankatsomuksellisia aineksia.

4. Kasvatus ymmärtämään eri kansojen kulttuuriperintöä, erityisesti eri maailmankatsomuksia tämän hetken maailmassa. Kasvatus kansainvälisyyteen.

Tästä luonnoksesta pyydettiin 12.2.1980 lausunto ylitarkastaja Olavi Aulalta, pääsihteeri Erkki Hartikaiselta, professori Juha Pentikäiseltä, lääninkouluttaja Esko Saariselta ja professori Annika Takalalta.

Uskonnon opetuksen ylitarkastaja Aula totesi lausunnossaan ehdotuksen käyttökelpoisemmaksi kuin sitä edeltäneen version, vaikka ehdottoman objektiivisuuden tavoite ei vieläkään hänen käsityksensä mukaan toteudu sillä tavalla kuin on kohtuullista odottaa voimassa olevien uskonnonvapaussäännösten pohjalta. Tämä siksi, että nykyistä maailmankatsomuksellista todellisuutta ja sen historiallista taustaa tarkastellaan liiaksi ateismiin tunnustautuneiden ihmisten näkökulmasta, mikä loukkaa opetukseen osallistuvia kristittyjä, juutalaisia ja muslimeja.

Vapaa-ajattelijain liiton pääsihteeri Erkki Hartikainen totesi lausunnossaan, että opetussuunnitelmaehdotus ei vastaa kansainvälisiä normeja, uskonnonvapauslakia eikä Suomen allekirjoittamaa kansalais- ja poliittisia oikeuksia

2 Luvun teksti perustuu Elon (1992, 13-15) artikkeliin; ks. myös Elo \& Linnankivi (1995, 122124). 
koskevaa sopimusta. Näiden syiden takia hän esitti täysin uudelleen kirjoitetun opetussuunnitelman.

Uskontotieteen professori Juha Pentikäinen sanoi oppimäärän sisältöjen olevan epätasapainoisessa suhteessa oppiaineen nimeen: uskontojen historian määrä oli hänen käsityksensä mukaan liian pieni. Hän ehdotti uskontojen systemaattista käsittelyä ala-asteella ja niiden vertailua yläasteella.

Uskonnon lääninkouluttaja Esko Saarinen piti oppimääräehdotusta selkeänä ja johdonmukaisena. Vaikka oppiaineksen ryhmittely tavoitealueittain vaikutti hänen mielestään akateemiselta, se ei kuitenkaan tulisi ilmeisesti vaikeuttamaan opetussuunnitelman tajuamista. Oppimäärää vastaavan oppiaineen nimeksi Saarisen mukaan olisi sopinut paremmin maailmankatsomus ja etiikka tai ihminen ja maailmankatsomus kuin uskontojen historia ja siveysoppi.

Professori Annika Takala totesi oppimääräehdotuksen monessa suhteessa kehittyneen myönteisesti suhteessa aikaisempaan opettajan oppaan luonnokseen. Hän toivoi otettavan paremmin huomioon kehityspsykologisen näkökulman erityisesti ala-asteen oppilaan maailmankuvan jäsentymättömyyden vuoksi.

Lausuntojen perusteella UH-työryhmä jätti syksyllä 1980 esityksensä ensimmäiseksi uskontojen historian ja siveysopin oppimääräksi, joka oli ilman uskonnollista viitekehystä. Kouluhallitus vahvisti oppimäärän kesällä 1981 . Kolme kuukautta aikaisemmin koululainuudistusta valmistellut työryhmä oli jättänyt opetusministeriölle mietintönsä, jossa ehdotettiin etiikan sisällyttämistä peruskoulun ja lukion lukusuunnitelmaan. UH-työryhmä oli tehnyt jo edellisenä vuonna tämän suuntaisen ehdotuksen.

\section{Elämänkatsomustieto ja vuoden 1985 koululainsäädännön uudistus}

Ennen vuotta 1985 voimassa ollut koululainsäädäntö sisältyi peruskoulun osalta Kansakoululakiin ja Lakiin koulujärjestelmän perusteista sekä lukion osalta useaan otteeseen muutettuun vuoden 1972 koulujärjestykseen. Tarve koota säännökset oli ilmeinen. (Numminen 1981, 12; Juntunen 1985, 2.)

Koululakien uudistusta oli valmisteltu jo 1970-luvulla. Silloin peruskoulun uskontojen historia ja siveysoppi ehdotettiin korvattavaksi uskontojen historialla ja etiikalla. Avauksenaan keskusteluun UH-työryhmä ehdotti elokuussa vuonna 1980 opetusministeriölle oppiaineen nimeksi etiikkaa, koska oppiaineen opetuksen lähtökohdan tuli olla yleishumanistisuus ilman uskonnollista viitekehystä. Ehdotus kantoikin nopean hedelmän, sillä Jaakko Nummisen johtama opetusministeriön työryhmä esitti maaliskuussa 1981 reilusti: "Milloin koulussa annettavasta uskonnon opetuksesta on uskonnonvapauslain mukai- 
sesti vapautettu vähintään kolme oppilasta, jotka eivät saa vastaavaa opetusta koulun ulkopuolellakaan, opetetaan heille uskonnon sijasta etiikkaa" (Elo \& Linnankivi 1995, 125). Lukion osalta mietintöön sisältyi vastaava esitys. UHtyöryhmä yritti laittaa vielä paremmaksi kääntymällä vaihteeksi kouluhallituksen puoleen kesäkuussa 1981. Nyt työryhmä esitti, että etiikka mainittaisiin tasa-arvon vuoksi peruskoulu- ja lukiolain oppiaineluettelossa ja että etiikkaa pitää opettaa sama tuntimäärä kuin uskontoa. (Elo 1992, 15.)

Hallituksen 12.3.1982 eduskunnalle antamassa esityksessä (30/1982 vp.) oli oppiaineen nimi muuttunut etiikasta uskontotiedoksi ja etiikaksi (ks. Numminen 1982, 60). UH-työryhmä käsitteli hämmentyneenä koululakiehdotusta. Nyt nähtiin, että nimitys uskontotieto ja etiikka saattaa supistaa oppiaineen sisältöjä niin, että ei-uskonnolliset elämänkatsomukset eivät saa riittävää osuutta opetuksessa. Työryhmä piti parhaana nimivaihtoehtona etiikkaa, mutta esitti myös harkittavaksi nimeä elämänkatsomustieto. Työryhmä ei voinut kuitenkaan suoraan vaikuttaa asiaan. Kouluhallituksen asettamana se saattoi vain tehdä esityksiä kouluhallitukselle. (Elo \& Linnankivi 1995, 125.)

Työryhmän sihteerin Pekka Elon ollessa 1.6.1982 kuultavana eduskunnan sivistysvaliokunnassa esitti hän muistiossaan:

Uskontojen historian ja siveysopin opetukseen osallistuvien oppilaiden huoltajat ovat pääosin katsomuksellisesti ei-uskonnollisia. Oppiaineen opetuksen sisältöjä on pyritty kehittämään katsomuksellisesti monipuolisiksi puolueettomista ja objektiivisista lähtökohdista käsin. Katsomuksellisesti monipuolista kehityspyrkimystä vastaisi oppiaineen nimenä etiikka tai esimerkiksi elämänkatsomustieto. (Elo 1992, 16.)

Samaan aikaan Vapaa-ajattelijain liitto oli pyrkinyt muuttamaan lakiesitystä niin, että tunnustukselliselle uskontojen opetukselle vaihtoehtoinen oppiaine rajattaisiin laissa koskemaan ainoastaan uskonnottomia oppilaita. Eduskunnan sivistysvaliokunta teki säännöksestä seuraavan esityksen: "Koulun yleisestä, uskonnon opetuksesta uskonnonvapauslain mukaisesti vapautetulle vähintään kolmelle uskontokuntiin kuulumattomalle oppilaalle opetetaan elämänkatsomustietoa. Lääninhallitus voi myöntää oppilasluvusta poikkeuksen." (Elo \& Linnankivi 1995, 126.) Vastaava säännös sisältyi lukiolakiesitykseen. Sivistysvaliokunnan mietinnössä (18/1982 vp.) otettiin huomioon elämänkatsomustiedon opetuksen osalta UH-työryhmän linjaukset. Eduskunta hyväksyi kevättalvella 1983 juuri ennen toimikautensa loppua koululait sivistysvaliokunnan esittämässä muodossa. (Elo 1992, 16.) Näin elämänkatsomustiedosta tuli uskonnon opetuksen rinnalle katsomusaine, jolla ei ollut uskonnollista viitekehystä.

Kesäkuussa 1983 kouluhallitus antoi UH-työryhmälle tehtäväksi peruskoulun ja lukion elämänkatsomustiedon oppimäärien valmistelun. Samalla 
kouluhallitus päätti kutsua työryhmän uusiksi jäseniksi lehtori Erkki Hartikaisen ja lehtori Tapani Lindlöfin. Työryhmä muutti nimensä Peruskoulun ja lukion elämänkatsomustiedon työryhmäksi (ET-työryhmä). Kouluhallitus vahvisti peruskoulun elämänkatsomustiedon oppimäärän 12.2.1985 työryhmän esityksen pohjalta. (Elo \& Linnankivi 1995, 126.)

Kouluhallitukseen perustettiin uskontojen historian ja siveysopin tilapäinen ja osa-aikainen ylitarkastajan toimi vuonna 1981. Kun uutta opetussuunnitelmaa valmisteltiin, toimi oli ajoittain kokopäiväinen. Se vakinaistettiin muutaman vuoden kuluttua ja siihen yhdistettiin filosofian opetuksen kehittäminen. Aineasiantuntijuuden rooli muuttui, kun keskushallintoa uudistettiin 1990-luvun alussa ja virkoihin ei enää määritelty tiettyjä ainekohtaisia tehtäviä. Palattiin siis eräällä tavalla tilanteeseen, jossa elämänkatsomustietoa oppiaineena hoidetaan keskushallinnossa muiden asioiden ohella.

\section{Elämänkatsomustieto lukion uutena oppiaineena}

Suomen oppikoulut olivat kirkon hiippakuntien tuomiokapitulien alaisia vuoteen 1869 asti. Silloin perustettiin kouluylihallitus, joka aloitti toimintansa 1.7.1870 samalla, kun uusi kirkkolaki tuli voimaan. (Hanho 1955, 169.) Oppikoululaitoksen hallinto järjestettiin 8.8.1872 annetulla koulujärjestyksellä Suomen Suuriruhtinaan maalle. Sen 6 §:ssä sanottiin: "Opetus kaikissa näissä oppiaineissa on yhteinen kaikille oppilaille, paitsi niissä aineissa, jotka ovat vapaaehtoisia tahi joiden suhteen on valitsemisen vapaus. Kuitenkin ovat vierasta uskoa tunnustavat lapset vapautetut yleiseen uskonnon opetukseen osaaottamasta." (Elo \& Linnankivi 1995, 127.)

Säädös ei koskenut uskontokuntiin kuulumattomia; heitä ei ollut, koska kuuluminen johonkin kristilliseen uskontokuntaan oli pakollista. Uskonnottomuus tuli mahdolliseksi vuoden 1923 alusta, mutta oppikouluja koskevassa lainsäädännössä tätä ei otettu huomioon. 1940-luvulla aiottiin aloittaa vaihtoehto-opetus. Opetuksen järjestämisestä antoi kouluhallitus kesäkuussa 1941 ohjeen: uskontojen historiaa ja siveysoppia opetettaessa noudatetaan pääasiassa samoja menettelytapoja kuin uskonnon opetuksessa. Käytännössä opetusta ei koskaan aloitettu. (Elo 1992, 17, alav. 20.)

ET-työryhmä oli siis vuonna 1983 saanut tehtäväkseen valmistella lukion elämänkatsomustiedon oppimäärän, joka oli samalla ensimmäinen uskonnon opetuksesta vapautetuille oppilaille tarkoitettu oppimäärä lukiossa. ET-työryhmä teki ehdotuksen, johon kuului viisi kurssia. Elämänkatsomustiedon ensimmäinen kurssi sisälsi moraalin ja elämänkatsomuksen perusteita. Tarkoituksena oli löytää elämäntavoitteista ja elämäntavasta yhteyksiä eettisiin periaatteisiin. Toisessa kurssissa perehdyttiin maailmankuvan, maailmankatsomuksen 
ja elämänkatsomuksen välisiin suhteisiin. Mukana oli aiheita olemassaolon rajoista taiteen mahdollisuuksiin avartaa ihmisen elämänkatsomusta. Kolmas kurssi oli yhteiskunnallisten kysymysten tarkastelua eettisestä näkökulmasta. Neljännessä kurssissa kartoitettiin eri kulttuurialueiden elämänkatsomuksia ja viimeisessä kurssissa pohdittiin elämänkatsomuksellisia ongelmia ja niiden ratkaisemista. (Lukion opetussuunnitelman perusteet 1985, 364-369; Elo 1992, 17.)

Oppiaineen sisällöistä todetaan yleisesti:

Lukion elämänkatsomustiedon oppiainekseen kuuluvat arvotietoisuuteen ja moraaliin liittyvät käsitykset, yhteiskunta- ja maailmankuvan katsomukselliset piirteet sekä käsitykset ihmisen tietämyksen mahdollisuuksista. Oppiaineksen valinnassa on otettava huomioon, että oppiainetta opetetaan uskontokuntiin kuulumattomille oppilaille. Opetuksen tulee kunnioittaen kotien katsomusperinnettä antaa virikkeitä sukupolvien väliselle katsomukselliselle vuorovaikutukselle. (Lukion opetussuunnitelman perusteet 1985,364 .)

Vuoden 1984 lopulla oppimääräluonnoksesta pyydettiin kommentteja asiantuntijoilta. Professori Annika Takala totesi oppimääräehdotuksen muodostavan yhtenäisen harkitun kokonaisuuden, jota hänen mielestään kannatti kokeilla sellaisenaan. Lisäksi hän ehdotti, että kursseja kannattaisi kokeilla samanaikaisesti myös opettajankoulutuksessa ja kokeilun jälkeen käyttää hyväksi koulun opetussuunnitelmien kehittämisessä laajemminkin kuin vain elämänkatsomustiedon opettamisessa. Vapaa-ajattelijat pitivät neljättä kurssia liian teologisena, mutta totesivat "työryhmän tehneet ensiarvoisen tärkeää työtä ja että monilta osin sen työ on maailman mittakaavassa uraa uurtavaa" (Opetushallituksen ET-arkisto). Kouluhallitus päätti lukion elämänkatsomustiedon oppimäärästä 13.3.1985 työryhmän ehdottamassa muodossa. Saman vuoden syksyllä alkoi opetus ja seuraavan vuoden keväällä elämänkatsomustieto oli mukana reaalikokeessa. (Elo \& Linnankivi 1995, 128.)

\section{ET ylioppilastutkinnon reaalikokeeseen}

Ylioppilastutkinto on lukion päättökoe, joka antaa yleisen jatko-opintokelpoisuuden (Lukiolaki 18 §). Siten ylioppilastutkintoon kuuluviin oppiaineisiin kohdistuu monia erityisiä odotuksia. Elämänkatsomustiedon kohdalla näiden odotusten lähtökohdat poikkeavat useimpien muiden reaalikokeen oppiaineiden vastaavista. Reaalikokeen useimmat aineet perustuvat omien erityistieteidensä perinteiseen näkökulmaan ja puhetapaan. Monitieteisessä elämänkatsomustiedossa sen sijaan painopisteenä on tukea opiskelijoiden elämänkatso- 
muksen ja identiteetin muotoutumista sekä heidän yhteisöllisten hyvän elämän ihanteidensa ja käytäntöjensä hahmottumista. Tavoitteena on kulttuurinen ja katsomuksellinen yleissivistys ja arviointikyky. (Lukion opetussuunnitelman perusteet 2003, 146.)

Elämänkatsomustieto sai omat kysymykset heti sen jälkeen kun lukion opetussuunnitelman perusteet hyväksyttiin vuonna 1985. Tehtäviä laativat ensimmäiset kolme vuotta professori Valde Mikkonen ja ylitarkastaja Pekka Elo, seuraavat kolme vuotta eli 1989-1991 professori Juhani Pietarinen ja Pekka Elo, tämän jälkeen tehtäviä ovat laatineet professori Timo Airaksinen ja Pekka Elo yhdessä dosentti Arto Siitosen ja tohtori Katri Kaalikosken kanssa. Vuonna 2001 ylioppilastutkintolautakunnan elämänkatsomustiedon ainejaos eriytettiin filosofian jaoksesta. Elämänkatsomustiedon ainejaoksen puheenjohtajana on toiminut Pekka Elo.

Sinänsä elämänkatsomustieto soveltuu hyvin ylioppilaskirjoituksiin, sillä katsomuksellista tietoa ja taitoa voidaan pitää tärkeänä sisältönä sekä eurooppalaisessa yleissivistyksessä että globaalimmassa mittakaavassa, ja elämänkatsomustiedon sisältöihin kuuluu olennaisesti koko maailman katsomuksellinen perinne ja kulttuuriperintö. Toisaalta elämänkatsomustiedon oppiainekuvaan liittyy kriittisen ajattelutaidon kehittämisen tavoite. Elämänkatsomustiedossa korostuu välineiden tarjoaminen oppilaan oman näkemyksen kehittämiselle ja sen perusteiden arvioinnille ja pohdinnalle. Näin oppilaan omat perustellut mielipiteet ja arvot saavat elämänkatsomustiedossa keskeisen aseman. Omien näkemysten esittäminen reaalivastauksessa on hyvä asia, joka onnistuessaan osoittanee kypsyyttä muissakin aineissa kuin elämänkatsomustiedossa. Vastaus ei kuitenkaan saa aueta kritiikittä vain omasta näkökannasta tai omista kokemuksista. Erilaiset elämänkatsomukset, kuten sekulaari humanismi ja uskonnot sekä filosofian perinne, ovat teoriakokonaisuuksia, jotka antavat kehikon ja puhetavan omienkin katsomuksellisten näkökulmien ja kokemusten avaamiseen ylioppilaskirjoituksissa.

Elämänkatsomustiedon reaalikokeen luonne asettaa koetehtäville korkeat vaatimukset. Nämä vaatimukset koskevat myös elämänkatsomustiedon lukioopintojen aiemmissa vaiheissa - kuten kurssikokeissa - oppimisen arvioinnin pohjana olevia tehtäviä, joihin nähden ylioppilaskokeella päättökokeena on ohjaava vaikutus. Tehtävien tulee painottua pohdintaa vaativiin soveltaviin tehtäviin, esimerkiksi uusiin tai klassisiin dilemmoihin ja paradokseihin. Ongelmakeskeisten ja pohdiskelevien vastausten arviointi on haastavaa. Mitään tarkkaa luetteloa siitä, mitä tietämällä saa tietyn määrän pisteitä, ei voida tehdä tapauksissa, joissa arvioidaan vastauksen argumentaation pätevyyttä, näkökulmien relevanssia ja monipuolisuutta. Tästä huolimatta vain ongelmakeskeiset tehtävät tekevät oikeutta elämänkatsomustiedolle. 
Keväällä 2006 elämänkatsomustiedon kuten muidenkin reaaliaineiden koe muuttui ainereaaliksi, joka suoritetaan vain yhdessä aineessa kerrallaan. Aiemmassa reaaliaineiden yhteisessä kokeessa edellytyksenä kokeeseen osallistumiseen oli tuolloisen ylioppilastutkintoasetuksen (1994/1000) 7 §:n mukaan, että kokelas on opiskellut vähintään kahden reaalikokeeseen kuuluvan oppiaineen pakollisen oppimäärän. Katsomusaineiden kannalta tässä oli se etu, että kokelas saattoi tämän säädöksen estämättä ilmoittautua katsomusaineiden kokeisiin siitä riippumatta, oliko kurssien opetusta järjestetty hänen lukiossaan tai oliko hän mahdollisesti vaihtanut katsomusainetta niin, että kaikkia pakollisia kursseja ei esimerkiksi elämänkatsomustiedosta ollut kertynyt. Ainereaalin järjestämistä säätelee näiltä osin laki ylioppilastutkinnon järjestämisestä (672/2005), jonka 4 §:ssä edellytetään, että kokeeseen saa osallistua vain, jos on suorittanut pakolliset kurssit aineessa, jonka kokeeseen hän osallistuu. Tämä aiheuttaa ongelmia, jos esimerkiksi elämänkatsomustiedon kurssien opetusta ei ole järjestetty tai lukiolainen on vaihtanut katsomusainetta kesken lukio-opintojen. Kärjistyneimmillään ongelma näyttäytyy kokelaalla, joka on osallistunut lukiossa sellaisen oman uskonnon opetukseen, jossa ei järjestetä ainereaalikoetta.

Osallistumisoikeus ainereaalikokeeseen jossain katsomusaineessa liittyy kahdella tavalla opiskelijan oikeusturvaan. Ensinnäkin katsomuksellisen tasaarvon (Perustuslaki 6 §) perusteella tietty vakaumus tai vakaumuksen vaihtaminen ei saa johtaa erilaiseen kohteluun. Toiseksi kansalaisella ja yksilöllä on myös oltava mahdollisuus käyttää oikeuksiaan: ilman perusoikeuksiin säädettyä poikkeusta alemmanasteisilla säädöksillä tai määräyksillä ei voida rajoittaa tai vaikeuttaa perusoikeuksien käyttöä. Laki ylioppilastutkinnon järjestämisestä (672/2005) jättää rehtorille jonkin verran harkintavaltaa ylioppilaskokeeseen osallistumisesta. Koska katsomusaineiden tapauksessa on kyse yleisestä ongelmasta, olisi asiaan syytä saada yhtenäinen perusoikeuksia kunnioittava linjaus eikä jättää ongelman ratkaisemista tapauskohtaisesti rehtorin harkittavaksi. Selkein ratkaisu olisi laskea pakollisiin kursseihin yhteen kaikki lukiossa suoritetut katsomusaineiden pakolliset kurssit katsomusaineen ainereaalioikeutta määritettäessä. Tämä ratkaisu perustuisi perustuslailliseen uskonnonvapauteen ja siihen, että lukiolaissa ( $7 \S$ ja 9 §) uskontoaineet ja elämänkatsomustieto rinnastetaan toisensa poissulkevina vaihtoehtoina. Näin meneteltäessä ei kyse ole sisällön suhteen vastaavien opintojen hyväksi lukemisesta, vaan muista lukion oppiaineista poikkeavasta säädösperustasta. Muunlainen järjestely tekee monessa tapauksessa katsomusvapauden käytön mahdottomaksi. 


\section{Vuoden 1994 opetussuunnitelmauudistus}

Keskustelu elämänkatsomustiedosta kohosi kuumaksi uutisaiheeksi vuoden 1989 alussa, kun joukko kansanedustajia teki vihreiden Pekka Haaviston johdolla eduskunta-aloitteen elämänkatsomustiedon avaamisesta kaikille oppilaille. (LA 10/1989 vp.) Jo tätä ennen oli Sdp:n vuonna 1987 hyväksyttyyn koulutuspoliittiseen ohjelmaan kirjattu vaatimus avata elämänkatsomustieto uskonnon opetukselle vaihtoehtoiseksi oppiaineeksi riippumatta oppilaan ja hänen vanhempiensa uskontokunnasta (Suomen sosialidemokraattinen puolue, 1987). Samaan aikaan Suomen Humanistiliitto keräsi nimiä samansuuntaiseen vetoomukseen (Elo 1992, 18).

Asiasta kehkeytyi varsin laaja julkinen keskustelu, jossa toisaalta korostettiin valinnanvapautta ja luottamusta vanhempien kykyyn valita itselleen sopivimpia ratkaisuja. Toisaalta korostettiin elämänkatsomustiedon sopimattomuutta kirkkoon kuuluville ja sitä, että kirkkoon kuuluvat vanhemmat ovat sitoutuneet antamaan lapsilleen oman tunnustuksensa mukaisen kasvatuksen. Keskustelu päättyi eduskunnan sivistysvaliokunnassa äänestykseen: aloitetta ei lähetetty eteenpäin. Myös aloitteen allekirjoittaneet Sdp:n kansanedustajat sivistysvaliokunnassa äänestivät aloitteen käsittelemistä vastaan. (Elo 1992, 18-19; Pikkusaari 1998, 15.)

Vuosikymmenen vaihteesta lähtien pohjustettiin yleissivistävän koulun opetussuunnitelmien uudistamista. Taustalla voi sanoa olleen informaatioteknologian kehitykseen liittyvä murros tietoa ja oppimista koskevissa käsityksissä. Merkkipaalu tiedon jatkuvan muuttumisen koululle asettamien haasteiden ymmärtämisessä oli Touko Voutilaisen, Jouko Mehtäläisen ja Ilkka Niiniluodon kirjanen Tiedonkäsitys, joka ilmestyi vuonna 1989. Samoihin aikoihin Suomeen rantautui ns. konstruktivistinen paradigma kasvatustieteissä. Käytännössä opetussuunnitelmien uudistus aloitettiin koulu- ja ammattikasvatushallitusten yhdistyttyä opetushallitukseksi vuonna 1992. Oppiaineisiin koottiin virkamiesvetoiset työryhmät: elämänkatsomustietoon ylitarkastaja Pekka Elo (pj.), kansainvälisyyskasvattaja Helena Allahwerdi, lehtori Olavi Arra, rehtori Satu Honkala, lehtori Tapani Lindlöf ja tutkija Hannu Simola. (Elo \& Linnankivi 1995, 128-129.)

1990-luvun alussa elettiin Suomessa uusliberalismin sävyttämää joustavuuden, deregulaation ja desentralisaation aikaa. Opetussuunnitelman perusteissa se näkyi väljyytenä. Esimerkiksi lukiossa elämänkatsomustiedon pakollisia kursseja kuvattiin kutakin neljällä virkkeellä - syventäville riitti yksikin. Mihinkään perusteita muuttaviin uudistuksiin verrattuna vuoden 1985 opetussuunnitelmiin ei nähty tarvetta, vaan kyseessä oli kokemusten huomioon ottaminen ja tyylin muutos. Esimerkiksi lukiossa säilytettiin hyvin samantapaisena kolmen ensimmäisen kurssin luonne: ensimmäisellä kurssilla käsi- 
teltiin hyvää elämää ja eettisiä kysymyksiä, toisella kurssilla tiedonhankintaa ja maailmankuvia ja kolmannella kurssilla perehdyttiin yhteiskunnallisiin ja yhteisöeettisiin kysymyksiin. Syventävissä kursseissa säilyi samoin sisältönä eri kulttuuriperinteisiin tutustuminen ja elämänkatsomuksellisten kysymysten erilaisten ratkaisujen pohtiminen. Yleisesti oppiaineen opiskelun tavoitteiksi todetaan seuraavasti:

- opiskelija erottaa asioiden katsomuksellisen näkökulman ja osaa tarkastella katsomuksellisten kysymysten ratkaisuja ihmisoikeusetiikan perusteelta ja

- opiskelijalle muodostuu monipuolinen katsomuksellinen yleissivistys, johon kuuluи eurooppalaisten ja muiden kulttuuripiirien katsomusperinteiden tuntemus. (Lukion opetussuunnitelman perusteet 1994, 91-92.)

Elämänkatsomustiedon opetussuunnitelmatyöhön vaikutti opetusministeriön tuntijakotyöryhmän esitys etiikan ottamisesta lukion opetusohjelmaan (Opetusministeriön työryhmien muistioita 1992:9). Aluksi lukion elämänkatsomustiedon tavoitteet ja sisällöt piti laatia siten, että tilaa jäi etiikka-nimiselle oppiaineelle. Eduskunnan hyväksymään oppiaineluetteloon etiikka ei kuitenkaan päätynyt ja siinä suhteessa tilanne loppujen lopuksi säilyi ennallaan. Uudeksi kaikille yhteiseksi oppiaineeksi tuli lukioon filosofia, jonka toinen syventävä kurssi oli ja on etiikka (Lukion opetussuunnitelman perusteet 1994, 94; Lukion opetussuunnitelman perusteet 2003, 152). Kun kaikille yhteinen ja uskonnosta riippumaton etiikka kuitenkin on ollut nimenomaan filosofista etiikkaa, sitä ei ilmeisesti ole koettu yhtä suurena uhkana kuin puhtaasti etiikka-nimistä oppiainetta. Kyse voi olla myös filosofisen etiikan määrällisestä pienuudesta: koko ikäluokka ei mene lukioon ja suurin osa lukiolaisistakaan ei opiskele syventävää etiikan kurssia.

Koska elämänkatsomustiedon sisällöt opetussuunnitelmissa olivat pitkälle filosofisia, syntyi kysymys elämänkatsomustiedon ja filosofian oppiainesten erityispiirteistä ja rajanvedosta. Kun 1994 opetussuunnitelman perusteiden tekstit olivat hyvin väljiä, eron määritteleminen jäi pitkälle paikallisten opetussuunnitelmien laatijoille ja käytännön opetustyöhön. Joidenkin elämänkatsomustiedon ja filosofian kurssien sisältöjen päällekkäisyydet olivat ilmeisiä (Ks. Lukion opetussuunnitelman perusteet 1994, 91-94). Opetushallituksen sekä Filosofian ja elämänkatsomustiedon opettajien pedagogisen ainejärjestön, FETO ry:n, edustajat tarjosivat eri foorumeilla ratkaisuja ongelmakenttään. Asiaa käsiteltiin mm. Itämeren maiden filosofian opetuksen kollokviossa (ks. Elo \& Korhonen, 1995; Tirkkonen 2005, 18) ja ainedidaktiikan symposiumissa Helsingin yliopistolla 1995 (ks. Elo, Savolainen \& Simola 1995). Valtakunnan tasolla elämänkatsomustiedon ja filosofian suhteita lukion oppiaineina täs- 
mennettiin seuraavalla opetussuunnitelmien uudistamisen kierroksella vuonna 2003.

\section{Vuosien 2003 ja 2004 opetussuunnitelmauudistukset}

1990-luvun keskivaiheilla Suomessa alettiin huolestua alueiden eriarvoistumisesta. Koulut alkoivat erilaistua muutenkin kuin omavalintaisella profiloitumisella, johon opetussuunnitelmauudistuksessa oli kouluja kannustettu. Ensimmäinen keskushallinnon takaisinveto vuonna 1994 voimaantulleiden opetussuunnitelmien perusteiden väljästä ohjauslinjasta oli peruskoulun päättöluokan hyvän osaamisen kriteereiden normittaminen. Teoksessa Perusopetuksen päättöarvioinnin kriteerit: arvosanan hyvä (8) kriteerit yhteisissä oppiaineissa (Opetushallitus 1999) pyrittiin asettamaan valtakunnallisia kriteerejä oppiaineiden arvostelulle. Pyrkimyksenä oli lisätä oikeudenmukaisuutta kaventamalla perusopetuksen päästötodistusten arvosanojen hajontaa suhteessa osaamisen tasoon. (Opetushallitus 1999; ks. myös Hosia-Paloposki 2006.)

Opetushallituksen selvityksessä lukiokohtaisten opetussuunnitelmien toteutumisesta vuoden 1994 uudistuksen jälkeen oli lisäksi todettu, että koulukohtaista opetussuunnitelmatyötä ei oltu joidenkin oppiaineiden kohdalla monissa kouluissa tehty, tai jos oli, tuloksena oli silloinkin ollut usein vain lyhyitä tavoite- ja sisältölistauksia. Selvityksessä huomautettiinkin muun muassa, että "opetussuunnitelman perusteiden normiluonnetta ei ole täysin ymmärretty" ja tämä on "vaarantanut oppilaiden oikeusturvaa". (Opetushallitus 2000, 40).

Huoli koulujen yhdenvertaisuudesta ja koulutuksellisesta tasa-arvosta, koulujen työrauhasta ja luokattoman lukion kääntöpuolista vaikutti opetussuunnitelmaprosessiin. Perusteiden normiluonnetta haluttiin korostaa ja niiden ohjaavuutta täsmentää, vaikka oppimiskäsityksessä sinänsä ei ollut tapahtunut suuria muutoksia vuoden 1994 opetussuunnitelman perusteisiin verrattuna (vrt. Peruskoulun opetussuunnitelman perusteet 1994, 9-10 ja Peruskoulun opetussuunnitelman perusteet 2004, 16).

Perusopetuksessa periaatteina olivat perusopetuksen yhtenäisyyden korostaminen ja valtakunnallisesti oppiaineittain määritellyt nivelkohdat. Perusopetuksen päättymisen lisäksi oppilaan hyvän osaamisen kriteerit on määritelty näihin nivelkohtiin. (Peruskoulun opetussuunnitelman perusteet 2004, 13.) Lukiokoulutuksessa puolestaan haluttiin taata myös pienempien lukioiden opiskelijoille tasavertainen asema ylioppilaskokeessa. Tämän suuntaisesti koko yleissivistävän koulutuksen opetussuunnitelman perusteet laadittiin vuoden 1994 perusteita tarkemmin ja opetuksen keskeiset tavoitteet ja sisällöt määriteltiin aiempaa yksityiskohtaisemmin. Vuoden 1994 opetussuunnitelman perusteet korostivat ratkaisevana lähtökohtana muutosta ja sitä, että opetus- 
suunnitelma palvelee koulua itseään ja antaa sille mahdollisuuden profiloitua (Lukion opetussuunnitelman perusteet 1994, 8-11, 19-20). Vuoden 2003 opetussuunnitelman perusteet puolestaan sitoo opetussuunnitelmatyön keskeisesti lainsäädäntöön perustuvaan opetussuunnitelmajärjestelmään (Lukion opetussuunnitelman perusteet 2003, 1).

Uusia kansallisia opetussuunnitelman perusteita laatimaan asetettiin työryhmät loppuvuodesta 2001. Perusopetuksen ryhmään kutsuttiin puheenjohtajaksi ylitarkastaja Pekka Elo, jäseniksi lehtori Eino Huotari, rehtori Satu Honkala, lehtori Hannu Juuso ja opettajankouluttaja Eero Salmenkivi. Lukion ET-työryhmään kutsuttiin puheenjohtajaksi Pekka Elo, jäseniksi lehtori Juha Eerolainen, lehtori Kari Koukkunen, lehtori Maria Nissilä, lehtori Pia Maria Nordström ja opettajankouluttaja Tuukka Tomperi.

Tässäkään opetussuunnitelmauudistuksessa ei nähty tarvetta suuriin elämänkatsomustiedon oppisisältöjä koskeviin muutoksiin. Olennainen kysymys oli elämänkatsomustiedon identiteetin määritteleminen ja sen roolin selkiyttäminen suhteessa filosofiaan, erityisesti lukiossa. Elämänkatsomustiedon ja filosofian keskinäinen läheisyys oli ollut paljolti tulosta oppiaineiden syntyyn ja historiaan liittyvistä käytännön kytköksistä. Filosofian ja elämänkatsomustiedon kouluopetuksen taustalla toimi monia samoja vaikuttajatahoja, kuten professorit Timo Airaksinen ja Ilkka Niiniluoto, oppiaineiden yhteinen ylitarkastaja Pekka Elo sekä yhteinen opettajajärjestö FETO ry. Myös Ylioppilastutkintolautakunnassa oppiaineiden suhde oli kiinteä. Elämänkatsomustiedon uutta profiilia linjattiin kahdessa FETO ry:n vuosikirjassa (2003 ja 2004), jotka laadittiin yhteistyössä Opetushallituksen kanssa (Heinlahti \& Elo 2003; Elo, Honkala \& Salmenkivi 2004).

Aiempaa tiukemmin opetusta normittavissa opetussuunnitelman perusteissa (lukio 2003 ja perusopetus 2004) eron tekeminen oli helpompaa kuin kymmenen vuotta aiemmin (ks. Lukion opetussuunnitelman perusteet 1994, 91-94; Lukion opetussuunnitelman perusteet 2003, 146-153). Työtä helpotti elämänkatsomustiedon identiteettiin kohdistunut tutkimuksellinen pohdinta, joka näkyi monissa artikkeleissa, joissa oli vuoden 1994 jälkeen suuntauduttu pohtimaan oppiaineen rajanvetoa suhteessa filosofiaan (esim. Savolainen et. al 1995; Elo \& Savolainen 2000; Salmenkivi 2003) ja hahmottelemaan uusia tapoja jäsentää elämänkatsomustiedon identiteettiä (esim. Kotkavirta 2003; Tomperi 2003).

Vuosien 2003 ja 2004 opetussuunnitelman perusteissa filosofian rinnalle elämänkatsomustiedon opetussisällöissä ja taustatieteissä tuotiin entistä vahvemmin kulttuuriperinnön opetusta sekä kulttuuritieteitä (esim. Honkala 1999; 2004; Elo 2000; 2004). Tämä on näkynyt esimerkiksi siten, että elämänkatsomustiedolla on ollut selkeä kytkentä Museoviraston, Opetushallituksen ja ympäristöministeriön yhteiseen kulttuuriperintöopetuksen kehittämisverkos- 
toon, Suomen Tammeen. Tässä yhteydessä elämänkatsomustiedossa on muun muassa pohdittu, mikä on erityisesti sekulaariin elämänkatsomukseen liittyvää kulttuuriperintöä.

Opetussuunnitelmauudistuksessa painotettiin elämänkatsomustiedon roolia yleiskasvatuksellisena oppiaineena ja sen panosta oppilaiden identiteettityössä ja samoin pedagogiikan merkitystä oppiaineen taustatieteenä (esim. Kotkavirta 2003; Tomperi 2004). Myös elämänkatsomustiedon yhteiskunnallista ulottuvuutta ja yhteiskuntatieteitä elämänkatsomustiedon taustatieteinä tuotiin aiempaa enemmän esiin. Vuosina 2005-2007 Opetushallituksen johdolla toteutettavan elämänkatsomustiedon kehittämishankkeen yhdeksi painopistealueeksi on puolestaan valittu estetiikka (Ks. Elo, Hulkki ja Kaila 2006, 9; Haapala 2006; von Bonsdorff 2006).

Yhteistä kaikille lähtökohdille, jotka määrittelevät elämänkatsomustiedon oppiaineena, on ollut näkemys elämänkatsomustiedon monitieteisyydestä. Näin on ollut niin opetuksen oppaissa ja tutkimusartikkeleissa (Kamppinen 1987; Savolainen \& al. 1995, 151-152; Simola 1995, 163, 183; Savolainen \& al. 1997, 30; Kotkavirta 2003; Salmenkivi 2003; Tomperi 2003; Tomperi 2004), oppikirjoissa (Hjelm \& Slotte 2001, 25-26; Tomperi \& al. 2002, 19-20; Tomperi \& Niemelä 2003, 7) kuin itse opetussuunnitelman perusteissakin (Lukion opetussuunnitelman perusteet 2003, 146; Peruskoulun opetussuunnitelman perusteet 2004, 214).

\section{Oppilasmäärien kehitys}

Elämänkatsomustiedon tuleminen koulun uudeksi oppiaineeksi oli siinä mielessä poikkeuksellinen koulua koskeva uudistus, että se toteutettiin kertarysäyksellä kaikilla kouluasteilla. Tämä oli mahdollista, koska taustalla ajateltiin olevan vanha oppiaine uskontojen historia ja siveysoppi. Sen opetus oli kuitenkin hyvin vähäistä ja opetuksen itsenäisen perinteen muodostumisen kannalta heikkoa. Siten käytännössä voi sanoa uuden oppiaineen syntyneen kaikille yleissivistävän koulutuksen tasoille yhtäaikaisesti. Tämän takia ei ole ihmeellistä, että vaikka uuden oppiaineen oppilaspohja - uskontokuntiin kuulumattomat - muodosti jo tuolloin yli kymmenesosan oppilaista, jäivät elämänkatsomustiedon oppilasmäärät kauas tämän määrän alle. Yksi olennainen syy oli, että elämänkatsomustiedon opetuksen toteutumisen ehtona oli se, että oppilas ensin vapautetaan uskonnon opetuksesta. Vanhemmat ilmeisesti hakivat tätä vapautusta varsin harvoin.

Elämänkatsomustiedon oppilasmäärien kasvu 1980-luvulla oli nopeaa ja melko tasaista kaikilla kouluasteilla. Oppilaita on aina ollut määrällisesti eniten alakoulussa, vaikka elämänkatsomustiedon prosentuaalinen osuus siellä 
on pienin (ks. Salmenkivi 2007). Tuhannen oppilaan raja rikkoutui jo ensimmäisenä lukuvuonna ala-asteella, seuraavana lukuvuonna yläasteen puolella ja jo kolmantena elämänkatsomustiedon opetuksen lukuvuonna lukiossa. Vuosikymmenen vaihteessa oli kaiken kaikkiaan ylitetty 10000 oppilaan raja. (Elo 1992, 19; ks. myös Elo \& Linnankivi 1995, 131.)

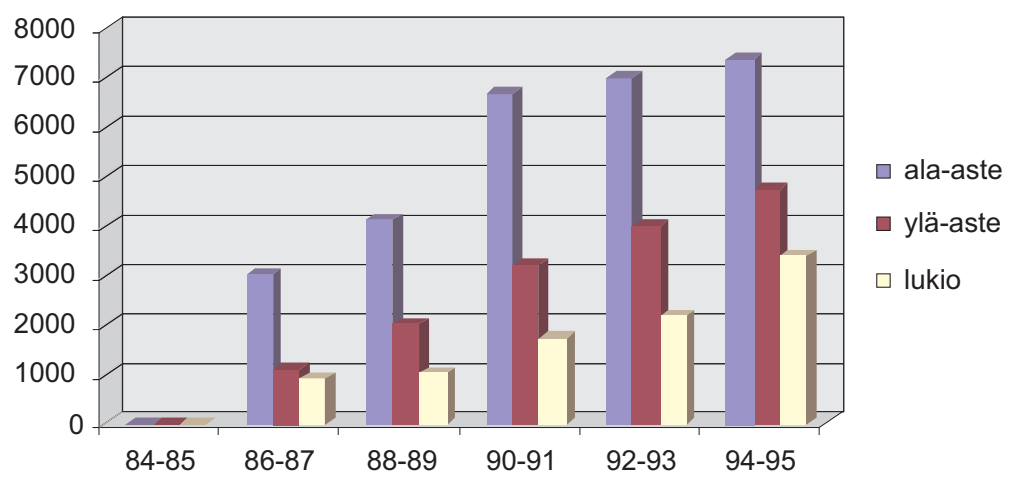

Kuvio 1. Oppilaiden lukumäärä elämänkatsomustiedossa vuosina 1984-1995 (Ks. Elo 1992, 19; Elo \& Linnankivi 1995, 131.)

1990-luvulla kasvu jatkui mutta hidastui. Esimerkiksi lukuvuonna 1994-95 oppiainetta opiskeli ala-asteella 7285 oppilasta (1,9 \%), yläasteella 4688 oppilasta $(2,4 \%)$ ja lukiossa 3350 oppilasta (3,1 \%) (Tilastokeskus 1995a; Tilastokeskus 1997b). Lukuvuonna 1996-97 vastaavat luvut olivat 7399 (1,95\%), 5054 (2,5\%) ja 3747 (3,4 \%) (Tilastokeskus 1997a; Tilastokeskus 1997b). Yhdeksänkymmentäluvun alun taloudellinen lama johti koulutoimessa merkittäviin säästötoimiin. Vuoden 1993 alusta voimaan astuneet uusi kuntien valtionosuuslaki (688/1992) ja laki opetus- ja kulttuuritoimen rahoituksesta (705/1992) jättivät entistä niukempia resursseja koskevan päätösvallan säästökohteista pitkälle kuntatasolle. Opetuksen järjestäjinä kunnat joutuivat säästämään ja monilla paikkakunnilla elämänkatsomustiedon opetus oli säästökohde. Jos opetusta ylipäätään toteutettiin, se tehtiin keskitetysti niin, että oppiainetta opiskelevia oppilaita yhdistettiin erityisjärjestelyin useista kouluista yhteisiksi opetusryhmiksi. Tämä on mahdollinen syy elämänkatsomustiedon oppilasmäärien kasvun hidastumiseen.

Vuosien 1997 ja 2002 välillä ei tilastoa oppilasmääristä elämänkatsomustiedossa kerätty. Lukion osalta tilastointimenetelmää myös muutettiin vuonna 1996. Siihen asti lukion elämänkatsomustiedon oppilasmäärä tarkoitti kaikkia lukion elämänkatsomustiedon opiskelijoita. Vuodesta 1996 alkaen lukiotilasto käsittää koko pakollisen oppimäärän suorittaneet opiskelijat eli vain lukion 
päättäneen ikäluokan. Tästä syystä 2000-luvun tilastot eivät ole suoraan vertailukelpoisia aiempien tilastojen kanssa. (Ks. Salmenkivi 2007.)

Hienoista kasvua oppilasmäärissä on edelleen tapahtunut. Alakoulussa on 2000-luvun ensimmäisen tilastoidun lukuvuoden 2003-2004 oppilasmäärä 8372 oppilasta noussut 8473:ksi lukuvuonna 2005-2006. Yläkoulussa vastaavien vuosien luvut ovat 5685 ja 5924 (Tilastokeskus 2005.) Yhteensä elämänkatsomustiedon oppilaita on lähes 15000 . Tämä on kuitenkin varsin pieni määrä, sillä se on alle $3 \%$ ikäluokasta, josta uskontokuntiin kuulumattomia on yli $10 \%$. Lukion päättäneissä oppilaissa elämänkatsomustiedon opiskelijoiden lukumäärä nousi 1526:sta 1582:een lukuvuodesta 2003-2004 lukuvuoteen 2005-2006. Tämä on noin 4,5 \% ikäluokasta. (Eri ikäluokkien osallistumisesta elämänkatsomustietoon ks. tarkemmin Salmenkivi 2007.)

Elämänkatsomustiedon oppilasmäärissä on havaittavissa erittäin huomattavia alueellisia eroja. Etelä-Suomen läänissä elämänkatsomustietoa opetetaan yli kaksi kertaa enemmän kuin muussa Suomessa yhteensä, vaikka läänin oppilasmäärä on vain reilu kolmannes koko maan oppilasmäärästä. Eniten oppilaita on Uudellamaalla niin kokonaismäärältään kuin suhteutettuna katsomusaineiden opiskelijamäärään. Esimerkiksi lukuvuonna 2003-2004 perusopetuksen 146711 uusmaalaisesta oppilaasta oli elämänkatsomustiedossa 8751 eli vajaa $6 \%$. Sen sijaan Etelä-Pohjanmaalla (22924 perusopetuksen oppilasta) ja Ahvenanmaalla (3091 perusopetuksen oppilasta) ei ollut lainkaan oppilaita elämänkatsomustiedossa, vaikka uskontokuntiin kuulumattomat oppilaat piti jo tuona lukuvuonna automaattisesti ohjata elämänkatsomustietoon. Lukion päättäneiden opiskelijoiden joukossa elämänkatsomustietoon osallistumisen prosentti vaihteli Uudenmaan 822/8662 opiskelijasta eli lähes $10 \%$ :sta KeskiPohjanmaan 2/622 opiskelijaan eli noin 0,3 \%:iin. (Tilastokeskus 2004a, b; ks Salmenkivi 2007.)

\section{Opettajat ja opettajankoulutus ${ }^{3}$}

Elämänkatsomustiedon pienistä opiskelijamääristä johtuen oppiaineen opettajankoulutuksen järjestämiseen ei kohdistunut suurta painetta. Itse oppiainetta saattoi opiskella muutamissa yliopistoissa approbaturin tai aineopintojen verran eli sivuaineen opettajapätevyyteen asti. Monissa opettajankoulutuslaitoksissa luokanopettajien oli puolestaan mahdollista suorittaa 1-2 opintoviikon laajuiset opetettavan aineen opinnot elämänkatsomustiedossa osana peruskoulussa opetettavien aineiden monialaisia opintoja.

Tämän luvun opettajankoulutusta koskevat tiedot perustuvat pitkälti eri yliopistoista Vokkeyhteistyön yhteydessä koottuihin tietoihin. 
Koska elämänkatsomus oli useimmille ainetta opettaville kolmas tai neljäs opetettava aine, oli täydennyskoulutuksen rooli merkittävä. 1990-luvun alussa käynnistettiin pätevöitymisohjelmia suuressa määrässä kansalais- ja työväenopistoja, joissa saattoi avointen yliopistojen oppivaatimusten mukaisesti suorittaa filosofiasta ja elämänkatsomustiedosta approbatur-arvosanan (15 ov). Näin tapahtuikin ja oppiainetta opettavat olivat muiden aineiden pääaineopettajia.

Filosofian tulo lukion yhteiseksi oppiaineeksi vuonna 1994 muutti tilannetta jonkin verran lukioissa. Filosofia ja elämänkatsomustieto on luonteva aineyhdistelmä, koska filosofian opettaja on jo aineopintojensa yhteydessä suorittanut ainakin noin kolmasosan elämänkatsomustiedon pätevyyteen vaadittavista opinnoista. Historia ja uskonto säilyivät 1990-luvulla yleisimpinä elämänkatsomustiedon opettajien pääaineina, mutta filosofia nousi niiden rinnalle kolmanneksi suosituimmaksi pääopetusaineeksi, jonka osuus näyttää olevan kasvussa. Kunkin osuus on noin viidennes, kun kaikkien muiden aineiden osuus yhteensä on noin kaksi viidesosaa. Helsingin ja muun Suomen välillä on ollut merkittävä ero siinä, kuinka usein elämänkatsomustiedon opettajan pääopetusaine oli uskonto. Helsingin lukioissa näin oli alle $15 \%$ :ssa ja muualla yli $25 \%$ :ssa tapauksista. (Salmenkivi 2007.)

Täydennyskoulutuksesta huolimatta vielä 2000-luvun alussa lähes kolmannekselle elämänkatsomustietoa lukiossa opettaneista ei ollut lainkaan oppiaineen yliopistollisia opintoja suoritettuina. Vajaalla viidenneksellä oli lyhyempi opintokokonaisuus ( 15 ov) ja hieman harvemmilla aineopinnot ( 35 ov). Perusopetuksen osalta tilanne on luokkien 7-9 osalta vielä heikompi. Luokanopettajan koulutusohjelmien monialaisten opintojen elämänkatsomustiedon kurssit, jotka useimmat yliopistot tarjosivat, tekivät luokka-asteiden 1-6 opettajista suhteellisesti selvästi pätevimpiä. (Salmenkivi 2007; ks. myös Rusama 2002, 38-39, 139, 241.)

Yliopistojen tarjoamat elämänkatsomustiedon arvosanaopinnot vaihtelivat suuresti sisällöltään ja toteutustavoiltaan yliopistosta toiseen. Myös niitä tarjoava oppiaine tai laitos vaihteli, joten opintokokonaisuuksien keskinäinen vastaavuus oli suhteellisen heikkoa. Sisällöllisesti ne koostuivat pääosin filosofiasta ja uskontotieteestä yhdistetyistä opintojaksoista. Opettajankoulutusta uudistettaessa yliopistojen tutkinnonuudistuksen yhteydessä vuosina 20032005 tähän problematiikkaan pyrittiin kiinnittämään huomiota. Yliopistojen tutkinnonuudistus osuikin heti yleissivistävän koulun opetussuunnitelmien uusimisen jälkeen, mikä antoi hyvän mahdollisuuden opettajankoulutuksen selkeyttämiseen.

Opettajankoulutuksen tutkinnonuudistusta ohjasi ns. Vokke-projekti (20032006), jossa elämänkatsomustieto oli sijoitettu yhteiseen jaokseen uskonnon kanssa. Koska elämänkatsomustiedon ja uskonnon aineenopettajakoulutus oli kuitenkin kaikissa yliopistoissa erillistä ja lisäksi muutamissa yliopistoissa elä- 
mänkatsomustiedon opintokokonaisuuksia hallinnoi filosofian laitos, pidettiin parhaana yhdistää elämänkatsomustieto ja filosofia samaan puoliviralliseen Vokke-ryhmään. Jaoksen tapaamisiin osallistui edustajia Helsingistä (Sokla ja filosofian laitokset), Jyväskylästä (filosofian laitos), Turusta (filosofian laitos) sekä Tampereelta (opettajankoulutuslaitos). Ryhmää koordinoi Eero Salmenkivi Helsingin yliopiston soveltavan kasvatustieteen laitokselta. Yhteenvedot ja pöytäkirjat tavoittivat myös muut yliopistot, mutta projektiin osallistuttiin aktiivisesti lähinnä Helsingin, Jyväskylän ja Tampereen yliopistoista.

Elämänkatsomustiedon opintokokonaisuus ja oppiaineen opettajankoulutus ovat kaikissa yliopistoissa hybridejä, jotka rakentuvat monitieteisesti. Opintojen hallinnoinnista vastaava laitos vaihtelee yliopistoittain. Helsingissä päävastuussa on käytännöllisen filosofian laitos ja oikeus merkinnän antamiseen on myös filosofian laitoksella, kun taas oppiaineen kehittämisessä on viime vuosina ollut näkyvimmin esillä soveltavan kasvatustieteen laitos. Joensuussa vastuussa on soveltavan kasvatustieteen laitos, Jyväskylässä yhteiskuntatieteiden ja filosofian laitos, Oulussa historian laitos, Turussa uskontotieteen oppiaine ja Tampereella filosofian yksikkö. Yleisin toteutusmuoto on se, että yksi laitos vastaa opintokokonaisuuden koordinoinnista ja kokonaismerkinnöistä ja opintojaksot on koottu useiden eri laitosten tarjonnasta. Poikkeuksen muodostaa Jyväskylän yliopisto, jossa yhteiskuntatieteiden ja filosofian laitos vastaa kaikista opintojaksoista ja järjestää opetuksen. Helsingissä, Joensuussa, Jyväskylässä ja Turussa järjestetään joko orientoiva kurssi elämänkatsomustiedon kokonaisuuden aluksi tai kokoava proseminaari sen lopuksi tai molemmat. Kokoavan kurssin tarjoaa Helsingissä, Joensuussa ja Turussa opettajankoulutuslaitos $^{4}$ ja Jyväskylässä filosofian yksikkö.

Elämänkatsomustiedon ja filosofian epävirallisessa Vokke-ryhmässä päädyttiin suosittelemaan, että yliopistojen ET-aineopintokokonaisuus koostuisi karkeasti ottaen seuraavasti: noin 20 op filosofiaa, noin 20 op kulttuuritieteitä (esimerkiksi uskontotiede, historia, kansatiede, antropologia), noin $10 \mathrm{op} \mathrm{yh-}$ teiskuntatieteitä ja noin 10 op elämänkatsomustiedon luonteeseen, historiaan ja kouluopetukseen orientoivia opintoja (esimerkiksi didaktisia sisältöjä, oppiaineen historiaa jne.). Suositukset välittyivät varsin hyvin yliopistoihin. Nykytilanteessa onkin ensimmäisen kerran saatu aikaan tyydyttävä vastaavuus eri yliopistojen tarjoamien elämänkatsomustiedon opintokokonaisuuksien välille.

Koska elämänkatsomustiedon arvosana pääosin rakentuu yliopistoissa muihin tarkoituksiin suunnitelluista osista eikä elämänkatsomustiedossa ole mahdollista suorittaa maisterintutkintoa, opetuksen käytännön toteutus riippuu pitkälti yliopistojen henkilökunnan omakohtaisesta paneutumisesta ja kiinnostuksesta - useimmiten muiden töiden ohella. Ainoastaan Helsingin yli-

4 Helsingin ja Joensuun yliopistoissa opettajankoulutusta antavan laitoksen nimi on soveltavan kasvatustieteen laitos. 
opistossa on ollut pari vuotta pelkästään filosofiaan ja elämänkatsomustietoon keskittynyt didaktikko, muissa yliopistoissa opinnot sijoittuvat vaihteleviin didaktisiin aineryhmiin. Erityisesti Jyväskylän yliopistossa filosofian yksikkö on ollut aktiivinen filosofian ja elämänkatsomustiedon kouluopetuksen ja didaktiikan edistämisessä ja harjoittanut myös alan tutkimusta.

Helsingin yliopistossa aloitetaan syksyllä 2007 opetusministeriön rahoituksella pilottihanke, jossa ensimmäistä kertaa koulutetaan elämänkatsomustiedon aineenopettajia. Koulutukseen otetaan lukuvuonna 2007-2008 enintään viisi elämänkatsomustiedon aineenopettajaksi opiskelevaa. Hankkeessa elämänkatsomustiedon opettajien koulutus on kytketty pienryhmäisten uskontojen eli Suomessa vähemmistönä olevien uskontoaineiden opettajankoulutukseen. Julkisuudessa kiinnostus nimenomaan näiden uskontojen opetukseen on ollut varsin suurta, vaikka oppilaspohjaltaan uskontokuntiin kuulumattomat on yli viisi kertaa suurempi katsomuksellinen vähemmistö kuin kaikki muut vähemmistöt yhteensä (ks. Salmenkivi 2007).

\section{Filosofian ja elämänkatsomustiedon opettajat - FETO ry}

Elämänkatsomustiedon opettajien pedagoginen ainejärjestö ETO ry perustettiin 28.4.1985. Erikoista oli, että tämä tapahtui jo ennen kuin uutta oppiainetta alettiin opettaa seuraavana syksynä. Järjestön ensimmäiseksi puheenjohtajaksi valittiin Eino Huotari. (Tirkkonen 2005, 9.) Syksyllä 1986 pedagogisen etujärjestön toimintaan otettiin mukaan lukion filosofian opettajat sekä Filosofian ja elämänkatsomustiedon opettajat. FETO ry oli saanut nykyisen muotonsa. (Tirkkonen 2005, 10.)

FETO muodostui muista poikkeavaksi aineenopettajien pedagogiseksi järjestöksi. Ensinnäkin luokanopettajien määrä on jatkuvasti ollut suuri, koska myös suuri osa opetuksesta ja opettajankoulutuksesta on kuulunut luokanopettajille. Toinen erikoinen piirre FETOn jäsenissä on se, että suurimmalle osalle FETOn alaan kuuluva oppiaine on toinen, kolmas tai peräti neljäs opetettava aine. Edelleen useilta opettajilta puuttuu muodollinen pätevyys, mihin liittyen työsuhteet voivat olla lyhyitä ja vaihtuvuus FETOn jäsenistössä on suurempi kuin muissa opettajajärjestöissä. Järjestön jäsenmäärä nousi 90-luvun alussa 300:aan ja ennätysvuonna 1998 jopa yli 570:n. Aktiivisesti jäsenmaksunsa maksaneiden määrä on kuitenkin 90-luvun alusta lähtien vaihdellut 300:n molemmin puolin. (Tirkkonen 2005, 11-12.)

Järjestön toiminnalle on ollut ominaista asialleen omistautuneen piirin aktiivinen talkootoiminta. Siihen on kuulunut vireä oppiaineiden edunvalvonta verkostoitumalla opetuksen kannalta tärkeiden tahojen kuten Opetushallituksen ja Ylioppilastutkintolautakunnan sekä muiden reaaliainejärjestöjen kanssa 
ja antamalla kannanottoja eduskunnan sivistysvaliokuntaa myöten elämänkatsomustietoon ja filosofiaan liittyvistä asioista (Tirkkonen 2005, 13-19). Muita merkittäviä yhteistyötahoja ovat olleet esimerkiksi Humanistiliitto ja Prometheus-leirien tuki ry. Viimeksi mainittu järjestö on itse asiassa syntynyt FETO-lähtöisesti. 1980-luvun lopulla elämänkatsomustietoa opiskelevat nuoret toivoivat itselleen aikuistumisleirejä rippikoululeirien vastapainoksi. Ensimmäinen tällainen Prometheus-leiri järjestettiin kesällä 1989 FETOn kahden ensimmäisen puheenjohtajan Eino Huotarin ja Vilhelmiina Rissasen toimiessa leirin ohjaajina. Leirien suosio kasvoi räjähdysmäisesti, ja niiden organisoimiseksi perustettu Prometheus-leirin tuki ry järjestää nykyään noin 60 Prometheus-leiriä vuodessa ja on kasvanut selvästi FETOa suuremmaksi järjestöksi. (Tirkkonen 2005, 24-25.) Prometheus-leiritoiminnalla on myös suora vaikutus elämänkatsomustiedon opiskeluun, koska leirien käynti näyttää parantavan ratkaisevasti elämänkatsomustiedon oppimistuloksia (Rusama 2002, 124). Prometheus-leirin tuki ry:n ja FETOn piiristä kasvanut on myös vuosittain nuorison filosofiatapahtuman vuodesta 2002 järjestänyt Nufit (Tirkkonen 2005, 25).

FETO on myös kuulunut kansainväliseen filosofian opettajien järjestöön (AiPPh) vuodesta 1992 alkaen. FETO järjesti Helsingin yliopiston filosofian laitoksen ja Opetushallituksen kanssa vuosina 1994 ja 1995 kaksi Itämeren maiden filosofian opettajien kollokviota, jotka käsittelivät filosofian didaktiikkaa (ks. Elo \& Korhonen 1995). Jälkimmäiseen kollokvioon osallistui Filosofiaa lapsille -liikkeen johtaja, professori Matthew Lipman USA:sta (Tirkkonen 2005, 18). FETO on muutenkin ollut erittäin aktiivinen elämänkatsomustiedon ja filosofian didaktisessa kehittämisessä. Järjestön aktiivit olivat esimerkiksi mukana kääntämässä ja toimittamassa Filosofiaa lapsille -ohjelman kirjoja ja opettajan oppaita suomeksi 1990-luvun alussa (ks. Elo \& Morehouse 1997; Lipman/Honkala, 1997, 7).

Oppiaineiden didaktiikan kehittämiseen liittyen FETO on ollut aktiivinen myös opettajien täydennyskoulutuksessa. Erityisesti Heinolan kurssikeskuksessa on sekä sitä vuodesta 1998 isännöineen Opetushallituksen alaisen opetusalan koulutuskeskuksen Opekon että sen edeltäjien aikana pidetty lukuisia elämänkatsomustiedon jatkokoulutustapahtumia, jossa fetolaisilla on ollut tärkeä rooli niin opettajina kuin opiskelijoinakin. Järjestön omassa koulutustoiminnassa merkittävällä sijalla ovat olleet syys- ja kevätkokoukset, joissa on vieraillut alustamassa suuri joukko valtakunnan eturivin filosofeja sekä muita katsomuksellisia vaikuttajia. Viimeisen parin vuoden aikana syyspäivät on järjestetty Suomen Humanistiliiton Humanismin päivien ja kevätpäivät puolestaan Tampere-talon Suuren filosofiatapahtuman yhteydessä. (Tirkkonen 2005, 19-21.) FETOn muuta opettajien täydennyskoulutukseen liittyvää toimintaa ovat olleet Suomen lähialueille, erityisesti Baltiaan, suuntautuneet kulttuuri- ja 
koulutusmatkat. FETOn toimintaan ovat liittyneet myös vuosittaiset pidemmät matkat erityisesti Intiaan ja Kaukoitään. (Tirkkonen 2005, 28-29.)

Olennainen osa FETOn toimintaa on ollut tiedottaminen ja julkaisutoiminta. Alkuaikojen jäsenkirjeet vakiintuivat 1990-luvun alussa neljä kertaa vuodessa ilmestyväksi jäsenlehdeksi. (Tirkkonen 2005, 26-27.) Vuosikymmenen puolivälissä järjestö julkaisi Pekka Elon ja Hannu Simolan toimittaman kymmenvuotishistoriikin Arvot, hyveet ja tieto, joka on pitkään toiminut elämänkatsomustiedon opettajankoulutuksen oppikirjana. Saman vuosikymmenen loppupuolella Helsingin opetustoimen filosofian ja elämänkatsomustiedon pedagogisena yhteyshenkilönä toiminut Juha Eerolainen loi järjestölle erittäin suositut verkkosivut (www.feto.fi). Kun ajankohtaisista asioista tiedottaminen siirtyi verkkoon, luovuttiin vuodesta 2003 alkaen jäsenlehdestä ja sen sijalle tuli painettu vuosikirja (Tirkkonen 2005, 27). Vuosien 2003 ja 2004 vuosikirjat Hyvän elämän katsomustieto ja Hyvän osaamisen katsomustieto keskittyivät ensisijassa elämänkatsomustietoon. Vuonna 2005 oli vuorossa FETOn 20-vuotisjuhlakirja, joka sisältää Jari Tirkkosen laatiman järjestön historiikin ja painottuu muutoin filosofiaan. Myös näitä vuosikirjoja on käytetty opettajankoulutuksen oppimateriaalina.

FETOlla on ollut merkittävää omaa julkaisutoimintaa, mutta yhtä tärkeää on ollut järjestön ja sen aktiivien osallistuminen erilaisiin yhteisjulkaisuihin. Erityisen tärkeää on ollut yhteistyö Opetushallituksen kanssa. Esimerkiksi järjestön vuoden 2006 vuosikirja Kaikki virtaa oli samalla Opetushallituksen katsomusaineiden kehittämishankkeen elämänkatsomustiedon osuuden perusaineisto. Opetushallituksen lisäksi FETOlla on ollut useita muita julkaisemisen yhteistyötahoja, kuten edellä esitetyt AiPPh ja Helsingin yliopiston filosofian laitos. Suomen uskonnon opettajien liiton kanssa on puolestaan julkaistu järjestöjen yhdessä marraskuussa 1996 järjestämän katsomusaineiden opettajien laatupäivien sato nimellä Hyveen ritarit (1997). Suomen UNESCO-toimikunta on puolestaan yhteistyössä FETOn ja muiden reaaliainejärjestöjen kanssa julkaissut tämän teoksen jatko-osan Ritarit reaaliajassa (1999). Fetolaisia on ollut mukana toimittamassa ja kääntämässä Suomen UNESCO-toimikunnan julkaisua Ihmisoikeuskasvatuksen käsikirja (2000). UNESCON ASP-kouluverkon kanssa on puolestaan julkaistu vuosittain vuodesta 2003 lähtien suomen ja englanninkielisiä esseitä ja artikkeleita sisältävä kirjanen UNESCOn maailman filosofian päivän annista. FETOlle tärkeä yhteistyötaho on ollut myös Helsingin kaupungin opetusvirasto, jonka julkaisua Sofiopolis, satoa ja sattumuksia helsinkiläisten koulujen filosofian tunneilta (1999) fetolaiset ovat olleet tekemässä. Lisäksi filosofisessa niin \& näin -aikakauslehdessä on julkaistu säännöllisesti vuodesta 1995 parhaiden filosofian ja elämänkatsomustiedon ylioppilaskirjoittajien vastauksia sekä katsaus kunkin vuoden ylioppilas- 
tehtäviin. Parhaat ylioppilaskirjoittajat FETO on palkinnut vuosittain keväällä yhdessä niin \& näin -lehden kanssa.

\section{Katsomusvapaus ja uusi uskonnonvapauslaki 2003}

Suomen uusi perustuslaki tuli voimaan vuonna 2000. Perustuslain $11 \S$ :ssä säädetään uskonnon ja omantunnon vapaudesta. Erikseen todetaan, että kukaan ei ole velvollinen osallistumaan omantuntonsa vastaisesti uskonnon harjoittamiseen. Myöhemmin uskonnonvapauslaki, perusopetuslaki ja lukiolaki harmonisoitiin vastaamaan perustuslakia. Koulun käytännön elämän kannalta kaksi kohtaa on herättänyt säädösten soveltamisessa erityisiä kysymyksiä: elämänkatsomustiedon opetuksen järjestäminen ja sellaiset koulun tilaisuudet, joissa on uskonnollisia elementtejä.

Vuonna 2003 uudistetun perusopetuslain 13 :ssä ja vastaavasti uuden lukiolain 9 §:ssä säädetään seuraavaa:

Uskonnollisiin yhdyskuntiin kuulumattomalle oppilaalle, joka ei osallistu 1 momentissa tarkoitettuun uskonnon opetukseen, opetetaan elämänkatsomustietoa. Uskonnolliseen yhdyskuntaan kuuluvalle oppilaalle, jolle ei järjestetä hänen oman uskontonsa opetusta, opetetaan huoltajan pyynnöstä elämänkatsomustietoa. Perusopetuksen järjestäjän tulee järjestää elämänkatsomustiedon opetusta, jos opetukseen oikeutettuja oppilaita on vähintään kolme.

Säädöksissä ei enää puhuta uskonnosta vapauttamisesta. Tämä tarkoittaa, että kaikki uskonnollisiin yhdyskuntiin kuulumattomat oppilaat ohjataan koulussa elämänkatsomustietoon. Sieltä heidän on mahdollista hakeutua enemmistön uskonnon opetukseen - perusopetuksessa huoltajan pyynnöstä ja lukiossa opiskelijan omalla ilmoituksella. (Opetushallitus 2006a, b.)

Elämänkatsomustiedon opetus järjestetään aina, kun kolmen opetukseen oikeutetun oppilaan sääntö täyttyy. Lukumäärä lasketaan opetuksen järjestäjän kaikista perusopetuksen (tai lukioiden tapauksessa lukiokoulutuksen) kouluista, kuitenkin erikseen suomen- ja ruotsinkieliseen opetukseen osallistuvista. Siten kolmen sääntö lasketaan esimerkiksi kaikista valtion perusopetusta antavista kouluista yhteensä. Kolmen lukumäärään otetaan mukaan myös muut elämänkatsomustiedon opetukseen oikeutetut oppilaat kuin uskontokuntiin kuulumattomat eli ne oppilaat, joiden omaa uskontoa ei opeteta. Opiskelun jo aloittaneiden oppilaiden opetus hoidetaan loppuun, vaikka opetusryhmän koko pienenisi alle kolmen. (Opetushallitus 2006a, b.)

Opetusjärjestelyt eivät saa aiheuttaa oppilaalle sellaista lisärasitusta, joka vaarantaa perustuslain $6 \S$ :n säätämän kansalaisten yhdenvertaisuuden. Koulu on velvollinen huolehtimaan oppilaan turvallisuudesta ja valvonnasta, jos op- 
pilaalle muodostuu vapaatunti koulupäivän aikana tai jos opetus järjestetään muussa kuin oppilaan omassa koulussa. (Opetushallitus 2006a.)

Suomalaisella koululla on useita perinteisiä juhlia kuten lukukauden päättäjäiset ja YK:n päivän sekä itsenäisyyspäivän juhla. Niihin saattaa joskus sisältyä uskontoon viittaavia osia. Eduskunnan perustuslakivaliokunta on lausunnossaan (Perustuslakivaliokunta 10/2002 vp) todennut, että tällaiset juhlatraditiot ovat osa suomalaista kulttuuria ja siksi mahdollisia osia kaikille yhteisessä koulun juhlassa. Juhlaan sisältyvä laulettu virsi tai jouluevankeliumin lukeminen ei tee koko juhlasta uskonnon harjoittamista. Tästä ei kuitenkaan seuraa poikkeusta perustuslain turvaamaan omantunnon vapauteen: kenenkään ei tarvitse osallistua näissä juhlissa niihin osuuksiin, joissa harjoitetaan uskontoa. Koska kyseessä ei ole uskonnollinen tilaisuus, elämänkatsomustiedon oppilaille ei tarvitse järjestää omaa tilaisuutta. (Opetushallitus 2006a; 2006b; ks. myös Arra 2006, 322.)

Koulutuksen vuosikirjassa todetaan "Ongelmakohtia ovat olleet mm. opettajan velvollisuudet osallistua uskonnollisiin tilaisuuksiin ja se, milloin koulun juhla on luonteeltaan uskonnollinen tilaisuus, johon osallistumisesta oppilas voi kieltäytyä. Katsomustaustaltaan heterogeenisissä kouluissa kannattaa pohtia myös itse juhlien suunnittelua tältä pohjalta." (Arra 2006, 322.) Perusopetuksessa oppilaan osalta päättävät huoltajat hänen osallistumisestaan juhliin. Jo oppilaan aloittaessa koulunsa kannattaa koulun kysyä näitä asioita oppilaan huoltajilta. Tällöin ei jokaisen tilaisuuden osalta tarvitse tiedustella erikseen. Peruskoulussa ja lukiossa aloitetaan edelleen koulupäivä lyhyellä päivänavauksella. Mikäli tilaisuus on luonteeltaan uskonnollinen (rukoilu, virret, uskonnolliset tarinat) on oppilaan osallistuminen tahdonvaraista. Sama koskee kevätjuhlien ja joulujuhlien mahdollisia uskonnollisia osuuksia. Juhlia voidaan kuitenkin eriyttää siten, että oppilailla on mahdollisuus poistua uskonnollisen osion ajaksi. Yksi virsi tai jouluevankeliumin lukeminen ei siis tee koko juhlasta uskonnollista tilaisuutta. (Arra 2006, 322.)

Koulun juhlat ovat osa opetusta ja koulutyötä. Perusopetuslain $3 \S: n$ mukaan opetuksessa tulee olla yhteistyössä kotien kanssa. Koulun tulee tiedottaa oppilaiden huoltajille koulussa järjestettävistä tapahtumista ja niiden sisällöstä. Tarvittaessa huoltajien kanssa voidaan sopia oppilasta koskevista yksilöllisistä järjestelyistä ja mahdollisesta vaihtoehtoisesta toiminnasta, mikäli vakaumus estää osallistumisen juhlaan tai sen osaan. Suomalaisen koulujuhlaperinnön vaalimisessa ja kehittämisessä lähtökohtana tulee olla yhteisöllisyyden ja suvaitsevaisuuden periaate. (Opetushallitus 2006a.)

Koulu voi järjestää uskonnollisia tilaisuuksia kuten jumalanpalveluksia ja uskonnollisia päivänavauksia. Tällaiset tilaisuudet katsotaan uskonnon harjoittamiseksi. Perustuslain 11 §:n 2 momentin mukaan ketään ei voida velvoittaa osallistumaan omantuntonsa vastaisesti uskonnon harjoittamiseen. Oppilaan 
huoltaja ilmoittaa, jos oppilas ei osallistu uskonnon harjoittamiseen. Ilmoituksen voi tehdä tapauskohtaisesti tai kertaluontoisesti esimerkiksi kouluun ilmoittauduttaessa. Ilmoituksen muodon päättää opetuksen järjestäjä (esimerkkinä ilmoituksen sisällöstä ks. Honkala 2004, 120). Ilmoituksen jälkeen koulu huolehtii siitä, että oppilas ei osallistu kyseisiin tilaisuuksiin. Koululla on vastuu oppilaan turvallisuudesta myös silloin, kun oppilas ei osallistu koulun järjestämään uskonnolliseen tilaisuuteen. Koulu järjestää oppilaalle tilaisuuden ajaksi muuta vastaavaa toimintaa. (Opetushallitus 2006a; 2006b.)

\section{Uskontojen ja elämänkatsomusten rinnastaminen}

Lähtökohtana katsomusvapaudelle koulussa ovat kaikkien ihmisten perusvapaudet ja -oikeudet sekä periaate ihmisoikeuksien yleisyydestä, jakamattomuudesta ja riippumattomuudesta. Periaatteet on ilmaistu Yhdistyneiden kansakuntien yleismaailmallisessa ihmisoikeuksien julistuksessa, Kansalaisoikeuksia ja poliittisia oikeuksia koskevassa kansainvälisessä yleissopimuksessa sekä julistuksessa kaikkinaisen uskontoon tai elämänkatsomukseen perustuvan suvaitsemattomuuden ja syrjinnän poistamisesta (25.11.1981 YKn yleiskokous 35/55; julkaistu suomeksi Elo et. al 1996).

Tuorein tämän alan kansainvälinen julistus on Yhdistyneiden Kansakuntien konfrenssissa vuonna 2001 annettu Madridin suositus katsomussyrjinnän poistosta kouluista (ks. The Oslo Coalition 2001). Sen perustana on YK:n yleiskokouksen tasan 20 vuotta aiemmin antama julistus. Madridin suosituksen lähtökohtina ovat myös UNESCOn vuoden 1960 sopimus kaikkinaisen syrjinnän poistamisesta opetuksen alueella sekä vuoden 1962 lisäpöytäkirja, UNESCOn vuoden 1974 kansainvälisyyskasvatussuositus ja YK:n Sosiaalisia ja taloudellisia oikeuksia koskeva yleissopimus sekä Lapsen oikeuksia koskeva kansainvälinen yleissopimus.

Madridin 2001 suosituksen mukaan kasvatuksen tulee tukea rauhaa, suvaitsevuutta, toisten yleistä hyväksyntää ja ihmisoikeuksien kunnioittamista ottamalla erityisesti huomioon uskonnon ja elämänkatsomuksen vapaus. Valtioiden tulee toteuttaa kouluopetus kunnioittaen uskontojen ja elämänkatsomusten erilaisuutta ja moninaisuutta. Tällä perusteella opetuksen tulee sisältää tietoja uskonnon ja elämänkatsomuksen vapaudesta, aineistoja, jotka lisäävät uskonnollista ja elämänkatsomuksellista suvaitsevuutta sekä ihmisten ja kansojen välistä vuorovaikutusta lisäävää ainesta. Sen tulee myös ottaa huomioon sukupuolten tasavertaiset mahdollisuudet. Lähtökohtana on lapsen vanhempien tai laillisten huoltajien tahdon kunnioittaminen koskien lapsen uskonnollista ja elämänkatsomuksellista kasvatusta. Edelleen valtioiden tulee kannustaa UNESCO-kouluverkkoa antamaan esimerkkiä tavoista toteuttaa tätä suositus- 
ta. Lisäksi niiden tulee tukea erilaisten aineistojen tuottamista, jotka palvelevat uskontoon tai elämänkatsomukseen perustuvan syrjinnän poistamista, ja tukea kansainvälistä kulttuurivaihtoa sekä kansalaisjärjestöjen pyrkimyksiä toteuttaa tämän suosituksen tavoitteita. (The Oslo Coalition 2001, julkaistu suomeksi Humanisti-lehdessä 3/2002.)

Kaikki edellä mainitut asiakirjat tunnustavat ajattelun, omantunnon, uskonnon ja elämänkatsomuksen vapauden. Kaikissa näissä asiakirjoissa uskonnon tai elämänkatsomuksen vapaus rinnastaa teistiset, ei-teistiset ja ateistiset katsomukset. Geneven ihmisoikeuskomissio käsitteli YK:n yleismaailmallisen ihmisoikeusjulistuksen $18 \S$ soveltamista vuonna 1993 (HR/GEN/1/Rev.5). Komissio totesi:

Artikla 18 suojelee teistisiä, ei-teistisiä ja ateistisia katsomuksia, samoin kuin oikeutta olla tunnustamatta mitään uskontoa tai elämänkatsomusta. Käsitteitä elämänkatsomus ja uskonto pitää tulkita laajassa mielessä. Artiklan 18 tulkinta ei rajoitu perinteisiin uskontoihin, järjestäytyneisiin uskontoihin ja elämänkatsomuksiin tai perinteisten uskontojen rinnastuvaan toimintaan. Tästä syystä komitea on huolissaan mihin tahansa uskontoon tai elämänkatsomukseen kohdistuvasta syrjinnästä mukaan lukien perustelut, että ne ovat äskettäin perustettuja, edustavat uskonnollisia vähemmistöjä, mikä saattaa olla syy valtauskonnon pyrkimykselle syrjiä niitä.

\section{Kolme tapaa järjestää katsomusopetus}

Kun pohditaan elämänkatsomustiedon tulevaisuutta, täytyy tarkastella koko suomalaista katsomusopetuksen mallia. Erilaisia katsomusopetuksen toteutusmalleja pohditaan aktiivisesti kasvatustieteellisissä tutkimuksissa eri puolilla maailmaa (Hobson \& Edwards 2004; Jackson 2003, 2004; Kallioniemi 2003, 2004a, 2004b, 2006; Kallioniemi \& Luodeslampi 2005; Larsson \& Gustavsson 2004; Skeie 2002, 2006). Katsomusopetuksen järjestämisen malli on keskeinen ja erittäin ajankohtainen kysymys nykyaikaisessa koululaitoksessa.

Katsomusopetukselliset ratkaisut valtiollisessa koulujärjestelmässä voidaan jakaa karkeasti kolmeen malliin: jokaiselle katsomuskunnalle oman oppiaineensa opetusta (esim. Suomi, Saksa osin, Itävalta), kaikille yhteinen katsomusopetuksen oppiaine (esim. Norja ja Ruotsi), ei lainkaan muusta opetuksesta erillistä katsomusopetusta (esim. Ranska ja USA pääosin). Näiden ohella voi kussakin järjestelmässä olla tunnustuskuntalähtöisten rinnakkaiskoulujen perinne, kuten hyvin merkittävässä määrin esimerkiksi Irlannissa, Englannissa ja Belgiassa, mutta suppeammassa muodossa useimmissa eurooppalaisissa maissa. Lisäksi uskonnon opetus voi ensimmäisessä mallissa olla joko tunnustuksellista uskonnon opetusta, kuten Suomessa vuoteen 2003 asti tai muodollisesti tunnustuksetonta 'oman uskonnon' opetusta, kuten ny- 
kyisten opetussuunnitelmien mukaan Suomessa. Jos katsomusopetusta ei ole koulussa omana oppiaineenaan, voidaan sen ajatella joko sisältyvän muuhun opetukseen tai sitten olevan kokonaan koulusta poissuljettuna. (Elo \& Linnankivi 1995; Larsson \& Gustavsson 2004; Schreiner 2000a; 2000b; 2001; 2005; 2006; Schreiner et. al 2002.)

Jos jokaiselle tarjotaan omaa opetusta, koulussa voidaan pyrkiä ottamaan huomioon eri katsomusryhmien sivistykselliset oikeudet. Tältä perustalta koulut järjestävät eri ryhmille omaa katsomusopetusta. Useimmiten rinnalla on sitoutumatonta opetusta, joka voi olla tarkoitettu kaikille niille, jotka koulussa eivät saa oman tunnustuksen mukaista uskonnon opetusta eli kuten toimittiin Suomessa ennen vuotta 1985. Toinen vaihtoehto on, että rinnakkainen opetus on rajattu uskontokuntiin kuulumattomille, kuten Suomessa 1985-2003. Tämän mallin myönteisenä perustana on kyky ottaa huomioon kotien kulttuuriperinne. Asianmukaisesti järjestettynä se ei takaa ainoastaan vapautta vieraan uskonnon harjoituksesta, vaan myös myönteisen oikeuden omaan opetukseen. Kielteisiä piirteitä ovat järjestelyhankaluudet, kalleus, pienimpien ryhmien putoaminen opetuksen ulkopuolelle sekä alttius vähemmistöjen painostamiselle enemmistön opetukseen. Hankaluuksia tai ratkaistavia kysymyksiä ovat opetusoikeudet sekä oppilaiden hakeutuminen opetukseen. Tässä mallissa uskontokuntiin kuulumattomat saavat tavallisesti vapautuksen opetuksesta tai opiskelevat uskonnon sijaan esimerkiksi yleisen etiikan tai filosofian kursseja. Suomalaisen elämänkatsomustiedon kaltaisia kyseistä ryhmää varten suunniteltuja oppiaineita ei ole muualla olemassa. Elämänkatsomustiedon vertailukohtia voi etsiä lähinnä kaikille oppilaille tarkoitetuista yhdistetyistä oppiaineista, joissa uskonnon osuus tosin on yleensä keskeinen (Englannin 'religious education' tietyillä luokka-asteilla) tai sitten yleiskasvatuksellisista oppiaineista, jotka yhdistelevät suomalaista terveystietoa, kansalaiskasvatusta ja katsomusopetusta (Etelä-Afrikan 'life orientation' sekä monien maiden kansalaiskasvatus, kuten Englannin 'citizenship education'). Rinnakkaismallia ovat eri muodoissa toteuttaneet Suomen ja Saksan (useimpien osavaltioiden) lisäksi esimerkiksi Luxemburg, Puola, Kroatia, Sri Lanka, Thaimaa ja Bangladesh. (Elo \& Linnankivi 1995, 129-130; Schreiner 2000a, 2000b; 2001; 2005; 2006.)

Kaikille yhteisenä opetetaan Ranskan valtion kouluissa etiikkaa ja Ruotsissa uskontotietoa. Mallin vahvuudet ovat selkeydessä: koulu on itsenäinen eikä erottele oppilaitaan katsomuksellisesti. Ruotsalaiset esimerkit ovat kuitenkin osoittaneet tämän mallin riskit. Maassa, jossa valtio ei ole katsomuksellisesti sitoutumaton ja jossa yhdellä katsomuksella on valta-asema, opetuksesta muodostuu yhden vallitsevan katsomuksen sävyttämää. Tästä syystä Ruotsissa on valtakirkkoon kuulumattomille annettu vapautuksia koulun uskontotiedon opetuksesta. Tällöin herää kysymys, miksi niillä oppilailla, jotka vapautetaan, 
ei ole oikeutta saada omaan katsomukseen perustuvaa opetusta koulussa. Myös sekulaarisuudelle tai tunnustuksettomuudelle (esim. Ranskan 'laïcité') perustuvissa koulujärjestelmissä on etenkin 2000-luvun aikana herännyt vilkas keskustelu monikulttuurisen yhteiskunnan tarpeista koulujen katsomusopetuksen suhteen (ks. esim. Debray 2002; Haarscher 2006.) Tätä kaikille yhteisen etiikan mallia toteutetaan muun muassa Bulgariassa, Espanjassa, Latviassa, Intiassa, Japanissa, Nepalissa, Pakistanissa ja Uudessa-Guineassa. (Elo \& Linnankivi 1995, 130; Schreiner 2000a; 2000b; 2001; 2005; 2006.)

Kolmas mahdollisuus on, että yleissivistävässä koulussa ei ole katsomuksellista oppiainetta. Useissa maissa eettisesti kasvattava oppiaines ja katsomuksiin liittyvät yleissivistävät tiedot on sisällytetty muihin kuin katsomuksellisiin oppiaineisiin. Näissä maissa on kyllä usein filosofian opetusta, mutta filosofiaa ei voida pitää aidosti katsomusaineena (ks. esim. Salmenkivi 2003, 36-37). Ongelmaksi järjestelmässä voi muodostua, että etiikan ja yleensä katsomusten teoriaan liittyviä käsitteitä ei opeteta kunnolla missään oppiaineessa. Toinen vaara on, että selvästi tunnustuksellinen oppiaines tunkeutuu esimerkiksi historian tai maantiedon opetukseen. (Elo \& Linnankivi 1995, 130-131.)

Katsomusopetuksen uudistaminen on erittäin ajankohtaista. Sekä maailmanlaajuisesti että Suomessa on niin, että samoilla alueilla toimii nyt samanaikaisesti enemmän uskontokuntia kuin koskaan aikaisemmin. Yhteiskuntien sisällä tämä näyttäytyy lisääntyvänä monikulttuurisuutena. Katsomusopetuksen kannalta on kiinnostavaa, että uskontokuntiin kuulumattomat eli ne, jotka ilmoittavat itsensä tilastoihin uskonnottomiksi tai ateisteiksi, ovat maailman kolmanneksi suurin katsomuskunta (n. 924 milj.), kristittyjen (n. 2,09 miljardia) ja muslimien (n. 1,27 miljardia) jälkeen (Barrett \& Johnson 2004). Suomessa kehitys on kulkenut selvästi sekularisaation suuntaan. Olennaista on ollut yhtenäiskulttuurin heikentyminen. Vuonna 2005 suomalaisista kuului evankelisluterilaiseen tunnustuskuntaan n. 83,1 \%. Muiden uskonnollisten ryhmien ja uskonnottomien lukumäärä (n. 13,5 \%) on kasvanut tasaisesti 1960luvun jälkeen, koska vielä vuoden 1970 tilaston mukaan luterilaiseen kirkkoon kuuluvia oli 95 \% väestöstä. (Kääriäinen, Niemelä \& Ketola 2003; Kääriäinen \& al. 2004.)

2010-luvun katsomusopetukseen liittyvät koulutuspoliittiset ratkaisut tehdään tilanteessa, jossa suomalainen yhteiskunta on kulttuurisesti moninaisempi kuin koskaan aikaisemmin. On huomattava, ettei monikulttuuristuminen merkitse vain valtaväestöstä erottuvien etnisten, uskonnollisten tai kulttuuristen ryhmien kasvanutta näkyvyyttä Suomessa, vaan koko suomalaisessa kulttuurissa ja sen vakiintuneina pidetyissä perinteissä tapahtuvaa murrosta. Katsomusopetuksen tutkimuksessa edellistä on kutsuttu 'perinteiseksi' monikulttuurisuudeksi ja jälkimmäistä 'moderniksi' monikulttuurisuudeksi (Skeie 1995, 2002). Murros merkitsee yhtäältä sitä, että aikaisemmin suhteellisen 
homogeeninen väestö on elämäntavoiltaan ja arvokäsityksiltään yhä eriytyneempää, ja toisaalta arkikulttuurissa ja mediassa omaksutaan yhä enemmän ylikansallisia vaikutteita.

Voidaan olettaa, että viimeistään seuraavan tuntijakopäätöksen ja opetussuunnitelmauudistuksen valmistelun yhteydessä, nousee vahvasti esiin kysymys suomalaisen katsomusopetuksen toteutusmalleista. Suurin kuviteltavissa oleva muutos olisi siirtyminen yhteiseen katsomusopetuksen malliin; se, että synnytettäisiin kokonaan uusi oppiaine, joka tarjottaisiin kaikille yhteiseksi uskonto- ja katsomusaineeksi. Tällaista on jo pitkään esitetty muutamalta taholta, etenkin taloudellisista syistä opetuksen järjestäjien eli kuntien näkökulmasta. Toinen mahdollisuus on, että nykymallissa lisätään valinnaisuutta tai karsitaan eri vaihtoehtoja. Eri katsomusryhmien tasapuolinen kohtelu edellyttää luultavasti molemmissa tapauksissa, että opetuksen peruslähtökohtana on elämänkatsomustieto rinnallaan esimerkiksi jonkinlainen kristinuskoon pohjaava uskonnon opetus. Kolmas mahdollinen muutos on se, että katsomusopetuksesta osa olisi kaikille yhteistä ja osa eriytyisi joko valinnan tai oppilaan katsomustaustan mukaisesti. Mikä tahansa yllä hahmotelluista muutoksista asettaa toteutuessaan merkittäviä haasteita elämänkatsomustiedon opettajille ja sen opettajankoulutukselle. Kaikkien mallien yhteisenä tekijänä on kuitenkin kasvava tarve edistää elämänkatsomustietoon liittyvien oppimistavoitteiden ja oppisisältöjen opetusta.

\section{Lähteet}

Arra, O. (2006). Uudistuneen uskonnonvapauslain vaikutuksista käytännön koulutyöhön. Teoksessa Kolehmainen, A. (toim.), Koulutuksen vuosikirja 2006-2007. PS-kustannus, Opettajien Kustannus.

Arra O. \& Honkala S. (toim.) (1999). Sofiopolis: Satoa ja sattumuksia helsinkiläisten koulujen filosofian tunneilta. Helsinki: Helsingin kaupungin opetusvirasto.

Arra, O. \& Tolonen, A. (toim.) (1997). Hyveen ritarit: Katsomusaineiden opettajien Laatupäivien satoa 29.-30.11.1996. Helsinki: FETO \& SUOL.

Barrett, D. B. \& Johnson, T. M. (2004). Annual statistical table on global mission: 2004. International Bulletin of Missionary Research 28(1), 24-25. http://search.atlaonline.com/pls/eli/ashow?aid=ATLA0001443388\&offset $=24 \&$ lcookie $=2960$ 034, luettu 17.1.2007.

Baumer, F. L. (1977). Modern European Thought: Continuity and Change in Ideas, 1600-1950. New York: MacMillan.

Brotherus K. R. (1923). Valtio ja kirkko: katsaus Suomen uskontolainsäädännön kehitykseen. Porvoo: WSOY.

Déclaration des Droits de l'homme et du citoyen du 26 août 1789. http://www.conseilconstitutionnel.fr/textes/d1789.htm, luettu 18.12.2006. 
Elo, P. (1992). Elämänkatsomustiedon tie. Katsomuksellinen vapautuminen Suomessa. Teoksessa Elo, P., Honkala, S. \& Simola, H. Elämänkatsomustieto koulussa: opetuksen perusteita etsimässä. Helsinki: Helsingin yliopisto, Lahden tutkimus- ja koulutuskeskus.

Elo P., Heinlahti, K. \& Kabata, M. (toim.) (2003). Hyvän elämän katsomustieto: FETO ry:n vuosikirja 2003. Helsinki: FETO.

Elo, P., Honkala, S. \& Salmenkivi, E. (toim.) (2004). Hyvän osaamisen katsomustieto: FETO ry:n vuosikirja 2004. Helsinki: FETO.

Elo, P, Hulkki, E \& Kaila, E. (toim.) (2006). Kaikki virtaa - Elämänkatsomustiedon perusta ja tulevaisuus. Opetushallituksen katsomusaineiden kehittämishanke/ elämänkatsomustieto. Helsinki: Opetushallitus, FETO \& Suomen Humanistiliitto.

Elo, P. \& Hänninen, K. (toim.) (1999). Ritarit reaaliajassa: kulttuuriperintö ja yleissivistys. Suomen UNESCO-toimikunnan julkaisuja no. 76. Helsinki: Suomen UNESCO-toimikunta, Museovirasto, Opetushallitus, BMOL, FETO, HYOL, Psykologianopettajat, SUOL.

Elo, P. \& Korhonen R. (eds.) (1995). Inquiries Concerning Philosophy Teaching. Baltic Sea Colloquim papers 1994. Reports from The Department of Philosophy, University of Helsinki, No 1 1995. Helsinki: Helsingin yliopiston filosofian laitos.

Elo, P. \& Linnankivi, J. (1995). Oikeuden ja kohtuuden tiellä. Teoksessa Elo, P. \& Simola, H. (toim.), Arvot, hyveet ja tieto: Elämänkatsomustiedon opetuksen 10-vuotisjuhlakirja, 117-131. Helsinki: FETO, Painatuskeskus.

Elo, P. \& Morehouse, M. (1997). Tällainen on filosofiaa lapsille ja nuorille. Teoksessa Lipman, M., Liisa: Eettisiä kysymyksiä, 5-13. Filosofiaa lapsille ja nuorille: opettajan opas. Kääntäneet ja toimittaneet Elo, P., Hakala, O. \& Korhonen, R. Helsinki: Edita.

Elo, P. \& Savolainen, J. (2000). Just Learning. In Airaksinen, T. \& Loukola, O. (eds.), New Ethics-New Society: At the Dawn of Justice. Acta Philosophica Fennica 65. Helsinki: Suomen filosofinen yhdistys.

Elo, P., Savolainen, J. \& Simola H. (1995). Filosofian ja elämänkatsomustiedon rajankäyntiä. Teoksessa Tella, S. (toim.), Juuret ja arvot: etnisyys ja eettisyys - aineen opettaminen monikulttuurisessa oppimisympäristössä. Ainedidaktinen symposiumi Helsingissä 3.2.1995, 87-96. Helsinki: Helsingin yliopiston opettajankoulutuslaitos. Tutkimuksia 150.

Elo, P. \& Simola H. (toim.) (1995). Arvot, hyveet ja tieto. Elämänkatsomustiedon opetuksen 10-vuotisjuhlakirja. Helsinki: FETO, Painatuskeskus.

Elo, P., Väyrynen, G. \& Saarinen-Elo, M. (1996). Humanistin juhlat. Helsinki: Suomen Humanistiliitto.

Finlex - Valtion säädöstietopankki. http://www.finlex.fi/; useita eri lukuajankohtia, luettu viimeksi 18.1.2007.

Haarscher, G. (2006). Tunnustuksettomuus. (La laïcité.) Suom. Kilpeläinen, T., $23^{\circ} 45$, niin \& näin -lehden julkaisusarja. Tampere: Eurooppalaisen filosofian seura.

Hanho, J. T. (1955). Suomen oppikoululaitoksen historia. Osa II, 1809-1872. Porvoo: WSOY. 
Honkala, S. (2004). Uskonnonvapauslaki ja ET-opetus. Teoksessa Elo, P., Honkala, S. \& Salmenkivi, E. (toim.), Hyvän osaamisen katsomustieto: FETO ry:n vuosikirja 2004. Helsinki: FETO.

Hosia-Paloposki, A. (2006). Opetussuunnitelma muokkautuu osana yhteiskunnallista muutosta. Didakta Varia 11(2), 126-128. Helsinki: Helsingin yliopiston soveltavan kasvatustieteen laitos.

Hämäläinen, E. (2003). ’Jumala varjelkoon kaikenlaisiin 'reformeihin' hukkuvaa kansaamme!" Etiikanopetus pedagogisena, poliittisena ja maailmankatsomuksellisena kiistakysymyksenä Suomessa vuoteen 1923. Suomen historian pro gradu -tutkielma. Tampere: Tampereen yliopisto.

Ihmisoikeuskasvatuksen käsikirja (2000). Suomen UNESCO-toimikunnan julkaisuja no. 78. Käännös ja toimittaminen Elo, P., Hakala, O., Häkkinen, K., Savolainen, J. \& Toppinen, T. Helsinki: Suomen kansallinen UNESCO-toimikunta.

Jackson, P. (ed.) (2003). Citizenship and Education: International perspectives on Religious and Cultural Diversity. London: Routledge Falmer.

Jackson, P. (2004). Rethinking Religious Education and Plurality. London: Routledge Falmer.

Juntunen, H. (1985). Uskonnon opetus ja valtiosääntö - Koulun uskonnon opetuksen asema valtiosääntöoikeudellisena kysymyksenä. Kirkon tutkimuskeskus Sarja A N:o 42. Jyväskylä: Kirkon tutkimuskeskus.

Kaitaro, T. (2003). Ranskalainen valistus ja järjen kritiikki. Teoksessa Korkman, P. \& Yrjönsuuri, M. (toim.), Filosofian historian kehityslinjoja, 289-306. Tampere: Gaudeamus.

Kallioniemi, A. (2003). European Solutions for Religious Education and Scenarios for Developing Finnish Model. Didacta varia 8(2), 31-38. Helsinki: Helsingin yliopiston soveltavan kasvatustieteen laitos.

Kallioniemi, A. (2004a). European solutions for religious education and the international standards for this subject: a Finnish approach. Didacta varia 9(1), 9-19. Helsinki: Helsingin yliopiston soveltavan kasvatustieteen laitos.

Kallioniemi, A. (2004b). Eurooppalaiset uskonnon opetusmallit ja suomalainen näkökulma. Teoksessa Ahonen, S. \& Siikaniva, A. (toim.), Eurooppalainen ulottuvuus. Ainedidaktinen symposiumi Helsingissä 6.2.2004, 338-347. Helsinki: Helsingin yliopiston soveltavan kasvatustieteen laitos. Tutkimuksia 252.

Kallioniemi, A. (2006). Religious education curricula in comprehensive schools in Scandinavia and Finland in the 1990's. In Tirri, K. (ed.), Nordic Perspectives on Religion, Spirituality and Identity. Yearbook 2006 of the Department of Practical Theology, 75-86. Helsinki: Helsingin yliopiston käytännöllisen teologian laitos.

Kallioniemi, A. \& Luodeslampi, J. (toim.) (2005). Uskonnon opetus uudella vuosituhannella. Helsinki: Kirjapaja.

Kamppinen, M. (toim.) (1987). Elämänkatsomustieto. Helsinki: Gaudeamus.

KM 1952:3. Kansakoulun opetussuunnitelmakomitea.

KM 1965:A7. Peruskoulukomitea.

KM 1970: A5. Peruskoulun opetussuunnitelmakomitea. 
Kotkavirta, J. (2003). Mitä elämänkatsomustieto voisi olla? Teoksessa Elo, P., Heinlahti, K. \& Kabata, M. (toim.), Hyvän elämän katsomustieto: FETO ry:n vuosikirja 2003, 41-49. Helsinki: FETO.

Kähkönen, E. (1976). Uskonnon opetuksen asema Suomen koulunuudistuksessa 19441970. Suomen teologisen kirjallisuusseuran julkaisuja 101. Helsinki: Suomen teologinen kirjallisuusseura.

Kääriäinen, K., Hytönen, M., Niemelä, K. \& Salonen K. (2004). Kirkko muutosten keskellä: Suomen evankelis-luterilainen kirkko vuosina 2000-2003. Kirkon tutkimuskeskuksen julkaisuja 89. Tampere: Kirkon tutkimuskeskus. (verkkojulkaisuna http://www.evl.fi/kkh/ktk/nelivuotiskertomus2000_2003/kertomus. pdf)

Kääriäinen, K., Niemelä, K. \& Ketola, K. (2003). Moderni kirkkokansa: Suomalaisten uskonnollisuus uudella vuosituhannella. Kirkon tutkimuskeskuksen julkaisuja 82. Tampere: Kirkon tutkimuskeskus. (verkkojulkaisuna http://www.evl.fi/kkh/ ktk/82.pdf)

Larsson, R. \& Gustavsson, C. (eds.) (2004). Towards an European Perspective on Religious Education. Stockholm: Artos \& Norma Förlag.

Lipman, M. (1997). Harri. Päättelyn taitoja. Filosofiaa lapsille ja nuorille, opettajan opas. Kääntänyt ja toimittanut Honkala, S., Helsinki: Edita.

Lukion opetussuunnitelman perusteet (1985). Helsinki: Kouluhallitus, Valtion painatuskeskus.

Lukion opetussuunnitelman perusteet (1994). Helsinki: Opetushallitus.

Lukion opetussuunnitelman perusteet (2003). Helsinki: Opetushallitus.

Luoma, M. (1967). Kristinuskon moraalikritiikki Edvard Westermarckin elämässä ja ajattelussa. Acta Universitatis Tamperensis. A, vol. 12. Tampere.

Metsikkö, J. (1913). Muutamia mietteitä kansakoulun uskonnon opetuksesta. Teoksessa Soininen, M. (toim.), Kasvatusopillisia tutkielmia 2. Helsinki: Otava.

Metsikkö J. O. (1959/1938). Uskontoa ennen ja nyt. Päänäkökohtia uskonnon historiasta. Lähinnä kansakoulun uskonnon historian opetusta varten. Viides painos. Helsinki: Otava.

Numminen, J. (1982). Koululainsäädännön kokonaisuudistus. Helsinki: Otava.

Opetushallitus (1999). Perusopetuksen päättöarvioinnin kriteerit: arvosana hyvä (8) kriteerit yhteisissä oppiaineissa. Helsinki: Yliopistopaino.

Opetushallitus (2000). Lukion opetussuunnitelmien analyysi lukuvuosilta 1996-1997 ja 1998-1999. Moniste 2/2000. Helsinki: Opetushallitus.

Opetushallitus (2006a). Muistio. Perusopetuslain muutoksen vaikutus uskonnon ja elämänkatsomustiedon opetukseen sekä koulun toimintaan. http://www.edu.fi/peruskoulu/uskonto/perusopetuslaki.pdf, luettu 28.12.2006.

Opetushallitus (2006b). Muistio. Lukiolain muutoksen vaikutus uskonnon ja elämänkatsomustiedon opetukseen sekä koulun toimintaan. http://www.edu.fi/lukio/ uskonto/lukiolaki.pdf, luettu 28.12.2006. Muistiot ovat päiväämättömiä, mutta sivuston mukaan perusopetusta koskeva muistio on vanhempi ja lukiota koskeva muistio on lähetetty lukioille Opetushallituksen tiedotteessa 28/2006, 31.3.2006.

Opetusministeriön työryhmien muistioita 1992:9. Tuntijakotyöryhmän muistio. Helsinki: Opetusministeriö. 
The Oslo Coalition (2001). Final document of the International Consultative Conference on School Education in Relation with Freedom of Religion or Belief, Tolerance and Non-Discrimination. http://www.oslocoalition.org/html/project school_education/final_document_madrid.html, luettu 18.1.2007.

Peruskoulun opetussuunnitelman perusteet 1994. Helsinki: Opetushallitus.

Pikkusaari, J. (1998). Vaikea vapaus. Sosialidemokratian häviö kirkolle 1850-luvulta 1920-luvulle käydyssä Suomen kulttuuritaistelussa. Bibliotheca Historica 32. Helsinki: Suomen Historiallinen Seura.

Porter, R. (1990). The Enlightenment. London: MacMillan.

Reijonen, M. (1977). Uskonnonvapauskysymys Suomessa. Kirkon tutkimuslaitos. Sarja A, nro 31. Helsinki.

Saine, H. (2000). Uskonnon opetus Suomen oppivelvollisuuskoulussa 1900-luvulla. Turun yliopiston julkaisuja. Sarja C, osa 165. Turku.

Salmenkivi E. (2003). Elämänkatsomustiedon rajoilla. Teoksessa Elo, P., Heinlahti, K. \& Kabata, M. (toim.), Hyvän elämän katsomustieto, 32-40. FETO ry:n vuosikirja 2003. Helsinki: FETO.

Salmenkivi E. (2007). Elämänkatsomustieto ja sen opetus. Teoksessa Sakaranaho, T. \& Jämistö, A. (toim.), Monikulttuurisuus ja uudistuva uskonnon opetus. (Painossa.) Helsinki: Helsingin yliopiston uskontotieteen laitos.

Savolainen, J., Elo, P. \& Simola, H. (1995). Rajankäyntiä. Teoksessa Elo, P. \& Simola, H. (toim.), Arvot, hyveet ja tieto: Elämänkatsomustiedon opetuksen 10-vuotisjuhlakirja, 149-160. Helsinki: FETO, Painatuskeskus.

Scheinin, M. (1995). Elämänkatsomustieto ihmisoikeutena. Teoksessa Elo, P. \& Simola, H. (toim.), Arvot, hyveet ja tieto: Elämänkatsomustiedon opetuksen 10-vuotisjuhlakirja, 132-141. Helsinki: FETO, Painatuskeskus.

Schreiner, P. (ed.) (2000a). Religious Education in Europe: A collection of basic information about RE in European countries. Münster: ICSS and the Comenius Institut.

Schreiner, P. (2000b). Religiöse Bildung in Europa. Ein Überblick. Münster: Comenius Institut.

Schreiner, P. (2001). Different Approaches-Common Aims? Current Developments in Religious Education in Europe. Münster: Comenius Institut.

Schreiner, P. (2005). Religious Education in Europe. Münster: Comenius Institut.

Schreiner, P. (2006). Zur Situation des Religionsunterrichtes - Ein Blick auf Europa. Münster: Comenius Institut.

Schreiner, P., Spinder, H., Taylor, J. \& Westerman, W. (eds.) (2002). Committed to Europe's Future: Contribitions from Education and Religious Education: A Reader. Münster: Coordinating Group for Religious Education in Europe (CoGREE) and the Comenius Institut.

Seppo, J. (1992). Vapaa-ajattelija liikkeen organisoituminen ja sen herättämä kiista Suomessa 1936-1946. Suomen kirkkohistoriallisen seuran toimituksia 156. Helsinki: Suomen kirkkohistoriallinen seura.

Seppo, J. (1992). Uskonnonvapaus 2000-luvun Suomessa. Helsinki: Edita Prima.

Skeie, G. (2002). The concept of plurality and its meaning for religious education. British Journal of Religious Education 25 (1), 47-59. 
Skeie, G. (2006). Diversity and the political function of religious education. British Journal of Religious Education 28 (1), 19-32

Suomen sosialidemokraattinen puolue, (1987). Pöytäkirja. SDP:n XXXIV puoluekokous, Helsinki 4.-7.6.1987. Helsinki: Suomen sosialidemokraattinen puolue.

Tamminen, K. (1967). Kansakoulun uskonnon historian ja siveysopin opetussuunnitelman hahmottuminen vuosina 1923-1950. Kasvatus 104 (3), 136-144.

Tilastokeskus (1995a). Peruskoulujen ainevalintatilasto 1995. Moniste.

Tilastokeskus (1995b). Lukiotilasto 1995. Moniste.

Tilastokeskus (1997a). Peruskoulujen ainevalintatilasto 1996. Moniste.

Tilastokeskus (1997b). Lukiotilasto 1996. Moniste.

Tilastokeskus (2004a). Peruskoulujen ainevalinnat 2003, oppilaiden katsomusainevalinnat syyslukukaudella 2003. Painamaton lähde, tulostettu Tilastokeskuksessa.

Tilastokeskus (2004b). Lukiokoulutuksen ainevalinnat 2003, lukion koko oppimäärän lukuvuonna 2002/2003 suorittaneiden katsomusainevalinnat. Painamaton lähde, tulostettu Tilastokeskuksessa.

Tilastokeskus (2005). Peruskoulujen ainevalinnat 2005, oppilaiden katsomusainevalinnat syyslukukaudella 2005. Painamaton lähde, tulostettu Tilastokeskuksessa.

Tirkkonen, J. (2005). Kaksi vuosikymmentä elämänkatsomustietoa ja filosofiaa. Teoksessa Honkala, S. \& Salmenkivi, E. (toim.), Hyvän opettamisen kaksi vuosikymmentä: FETO ry:n vuosikirja 2005, 9-31. Helsinki: FETO.

Tomperi, T. (2003). Elämänkatsomustiedon identiteetti opetussuunnitelmassa. Teoksessa Elo, P., Heinlahti, K. \& Kabata, M. (toim.), Hyvän elämän katsomustieto: FETO ry:n vuosikirja 2003, 10-31. Helsinki: FETO.

Voutilainen, T., Mehtäläinen, J. \& Niiniluoto, I. (1989). Tiedonkäsitys. Helsinki: Kouluhallitus, Valtion painatuskeskus. 


\section{Kirjoittajat}

Tuulia Ahola-Luttila, fil.yo, valtionhallinnon harjoittelija

Opetushallitus

tuulia.ahola-luttila@helsinki.fi

Pekka Elo, VTM, ylitarkastaja

Opetushallitus

pekka.elo@oph.fi

Arto Kallioniemi, TT, KM, professori

Soveltavan kasvatustieteen laitos, Helsingin yliopisto

arto.j.kallioniemi@helsinki.fi

Jussi Kotkavirta, FT, professori

Yhteiskuntatieteiden ja filosofian laitos, Jyväskylän yliopisto

jkotkavi@yfi.jyu.fi

Kaarina Lyhykäinen, TM, jatko-opiskelija

Soveltavan kasvatustieteen laitos, Helsingin yliopisto

kaarina.lyhykainen@helsinki.fi

Liisa Odiah, TM, jatko-opiskelija

Soveltavan kasvatustieteen laitos, Helsingin yliopisto

liisa.odiah@lyk.fi

Antti Räsänen, TT, KM, dosentti, yliopistonlehtori

Käytännöllisten teologian laitos, Helsingin yliopisto

antti.rasanen@helsinki.fi

Tuula Sakaranaho, dosentti, yliopistonlehtori

Uskontotieteen laitos, Helsingin yliopisto

tuula.sakaranaho@helsinki.fi

Eero Salmenkivi, FL, yliopistonlehtori

Soveltavan kasvatustieteen laitos, Helsingin yliopisto

eero.salmenkivi@helsinki.fi

Friedrich Schweitzer, Professor for practical theology and religious education, Protestant faculty of theology, Eberhard-Karls-Universität Tübingen, Germany sekretariat.schweitzer@uni-tuebingen.de

Tuukka Tomperi, FM, tutkija

Opettajankoulutuslaitos, Tampereen yliopisto

tuukka.tomperi@uta.fi 



\section{Vokke-projektin kustantamat julkaisut}

Kallioniemi, Arto \& Salmenkivi, Eero (toim.) (2007) Katsomusaineiden kehittämishaasteita. Opettajankoulutuksen tutkinnonuudistuksen virittämää keskustelua. Tutkimuksia 279. Helsinki: Soveltavan kasvatustieteen laitos. Kirja on julkaistu Soveltavan kasvatustieteen laitoksen Tutkimuksia-sarjassa:

http://www.helsinki.fi /behav/kirjasto/palvelut/julkaisumyynti/soklatut3

Vokke-projekti on julkaissut kirjan verkkojulkaisuna:

http://www.helsinki.fi/vokke/english/katsomus.pdf

ISSN 1795-2158, ISBN 978-952-10-3598-2 (nid.), ISBN 978-952-10-3599-9 (Pdf).

Jakku-Sihvonen, Ritva \& Niemi, Hannele (Eds.) (2007) Education as a Societal Contributor. Reflections by Finnish Educationalists. Frankfurt a.M.: Peter Lang. ISBN 978-3-631-56881-1. 240 pages.

Orders: Peter Lang Publishing Group (http://www.peterlang.com/)

Jakku-Sihvonen, Ritva \& Niemi, Hannele (Eds.) (2006) Research-based Teacher Education in Finland - Reflections by Finnish Teacher Educators. Research in Educational Sciences 25. Helsinki: Finnish Educational Research Association. ISBN 952-5401-24-3. 230 sivua, 26 euroa.

Tilaukset: Suomen kasvatustieteellisen seuran verkkosivun kautta (http://www. kasvatus.net/english.html) tai sähköpostitse (mari.broberg@utu.fi).

Jakku Sihvonen, Ritva (toim.) (2006) Taide- ja taitoaineiden opetuksen merkityksiä. Teatterikorkeakoulun julkaisusarja, 39. Helsinki: Helsingin yliopisto \& Teatterikorkeakoulu.

ISSN 0783-3385, ISBN 952-9765-40-1 (nid.), ISBN 952-9765-41-X (PDF). 91 sivua.

Kirja on julkaistu verkkojulkaisuna Teatterikorkeakoulun verkkosivulla: http:// www.teak.fi/julkaisut/TeaK39.htm

Suora linkki verkkojulkaisuun: http://www.teak.fi/julkaisut/TeaK39.pdf

Jakku Sihvonen, Ritva (toim.) (2005) Uudenlaisia maistereita. Kasvatusalan koulutuksen kehittämislinjoja. Opetus 2000. Jyväskylä: PS-kustannus.

ISBN 952-451-108-8. 364 sivua. 34 euroa.

Tilaukset: PS-kustannus: verkkolomakkeella (http://www.ps-kustannus.fi/shop. htm), puhelimitse (+358-14-3370 070) tai sähköpostitse (asiakaspalvelu@pskustannus.fi). 
Vokke-projektin kasvatusalan täydennyskoulutuksen työryhmä (2006) Kasvatusja opetusalan täydennyskoulutuksen strategia. Helsinki: Käyttäytymistieteellinen tiedekunta, Helsingin yliopisto.

Raportti on julkaistu verkkojulkaisuna: http://www.helsinki.fi/vokke/taydennys koulutus

Suora linkki verkkojulkaisuun: http://www.helsinki.fi/vokke/Tyoryhmat/Tayden nyskoulutuksen\%20strategia_060206.pdf

Vokke-projektin kasvatusalan jatko-opintojen kehittämistyöryhmä (2006). Kasvatustieteellisen alan tohtorikoulutuksen kehittäminen. Helsinki: Käyttäytymistieteellinen tiedekunta, Helsingin yliopisto.

ISBN 952-10-3190-5 (nid.), ISBN 952-10-3191-3 (PDF).

Raportti on julkaistu verkkojulkaisuna: http://www.helsinki.fi/vokke/jatkokou lutus

Suora linkki verkkojulkaisuun: http://www.helsinki.fi/vokke/Tyoryhmat/Loppura portti.pdf 


\section{Tutkimuksia: Viimeisimpiä julkaisuja}

$(12 €)$

265 Erkki Pehkonen, Gerd Brandell, Carl Winsløw (eds.) 2006. Nordic Presentations. Proceedings of the section Nordic Presentations at ICME-10, July 12, 2004 in Copenhagen (Denmark).

266 liris Attorps 2006. Mathematics teachers' conceptions about equations.

267 Marja Nurmilaakso 2006. Lukemisen alkeita päiväkodissa. Lastentarhanopettaja ja alkava kuusivuotias lukija.

268 Sirpa Tani (ed.) 2006. Sustainable Development through Education. Proceedings of the International Conference on Environmental Education. Helsinki, 14 June 2005.

269 Pirjo Aunio 2006. Number sense in young children-(inter)national group differences and an intervention programme for children with low and average performance.

270 Alisa Alijoki 2006. Erityistä tukea tarvitsevien lasten polut esiopetuksesta alkuopetukseen - Tukitoimet ja suoriutuminen.

271 Ismo-Olav Kjäldman 2006. Self-Concept and School Achievement of Pupils with Cleft Lip, Cleft Palate or Both. A longitudinal study.

272 Tuula Tonttila 2006. Vammaisen lapsen äidin vanhemmuuden kokemus sekä lähiympäristön ja kasvatuskumppanuuden merkitys.

273 Pirjo Harjanne 2006. "Mut ei tää oo hei midsommarista!" - ruotsin kielen viestinnällinen suullinen harjoittelu yhteistoiminnallisten skeema- ja elaborointitehtävien avulla.

274 Seija Hassinen 2006. Idealähtöistä koulualgebraa. IDEAA-opetusmallin kehittäminen algebran opetukseen peruskoulun 7. luokalla.

275 Nwachukwu Prince Ololube 2006. Teacher Education, School Effectiveness and Improvement. A Study of Academic and Professional Qualification on Teachers' Job Effectiveness in Nigerian Secondary Schools.

276 Auli Toom 2006. Tacit Pedagogical Knowing. At the Core of Teacher's Professionality.

277 Marja Spoof 2007. "Pintaa syvemmälle" - eettinen pohdinta opettajan voimavarana luokanopettajan ja erityisopettajan silmin.

278 Martin Ubani 2007. Young, gifted and spiritual-The case of Finnish sixth-grade pupils

279 Arto Kallioniemi ja Eero Salmenkivi (toim.) 2007. Katsomusaineiden kehittämishaasteita. Opettajankoulutuksen tutkinnonuudistuksen virittämää keskustelua. (Saatavissa verkkojulkaisuna) 
Julkaisija

Soveltavan kasvatustieteen laitos

Käyttäytymistieteellinen tiedekunta

PL 9

00014 Helsingin yliopisto

www.helsinki.fi/sokla/julkaisut

ISBN 978-952-10-3598-2

Yliopistopaino

Helsinki 2007 